\title{
Connecting to the Internet Securely; Windows 2000 CIAC-2321
}

W.J. Orvis, K.Call, and J. Dias

U.S. Department of Energy

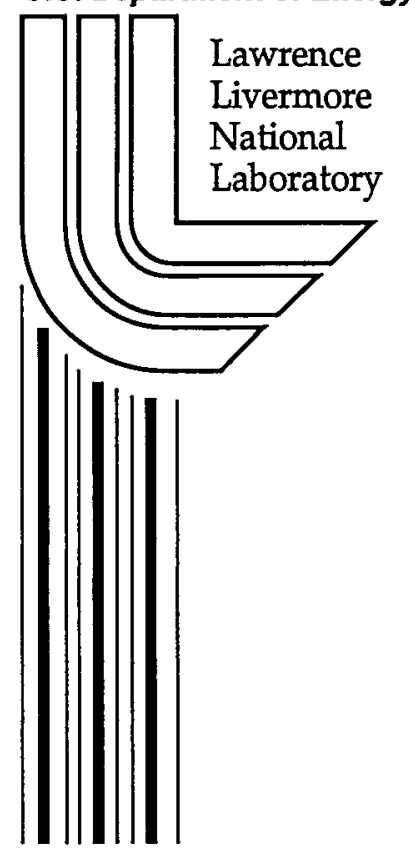

March 12, 2002 


\section{DISCLAIMER}

This document was prepared as an account of work sponsored by an agency of the United States Government. Neither the United States Government nor the University of California nor any of their employees, makes any warranty, express or implied, or assumes any legal liability or responsibility for the accuracy, completeness, or usefulness of any information, apparatus, product, or process disclosed, or represents that its use would not infringe privately owned rights. Reference herein to any specific commercial product, process, or service by trade name, trademark, manufacturer, or otherwise, does not necessarily constitute or imply its endorsement, recommendation, or favoring by the United States Government or the University of California. The views and opinions of authors expressed herein do not necessarily state or reflect those of the United States Government or the University of California, and shall not be used for advertising or product endorsement purposes.

This work was performed under the auspices of the U. S. Department of Energy by the University of California, Lawrence Livermore National Laboratory under Contract No. W-7405-Eng-48.

This report has been reproduced directly from the best available copy.

Available electronically at http://www.doc.gov/bridge

Available for a processing fee to U.S. Department of Energy

And its contractors in paper from

U.S. Department of Energy

Office of Scientific and Technical Information

P.O. Box 62

Oak Ridge, TN 37831-0062

Telephone: (865) 576-8401

Facsimile: (865) 576-5728

E-mail: reports@adonis.osti.gov

Available for the sale to the public from

U.S. Department of Commerce

National Technical Information Service

5285 Port Royal Road

Springfield, VA 22161

Telephone: (800) 553-6847

Facsimile: (703) 605-6900

E-mail: orders@ntis.fedworld.gov

Online ordering: http://www.ntis.gov/ordering.htm

OR

Lawrence Livermore National Laboratory

Technical Information Department's Digital Library

http://www.llnl.gov/tid/Library.html 


\section{TABle OF Contents}

Disclaimer........................................................................................................................................i

Table of Contents .........................................................................................................................ii

1 Overview.................................................................................................................... 1

2 Remote Management Considerations in Windows 2000.......................................3

2.1 Domain Security Settings with Group Policy ................................................... 3

$\underline{2.2}$ Automatic System Installation ...................................................................... 4

2.3 Desktop Mirroring and Software Installination ............................................... 4

2.3.1 Automatic Software Installation............................................................. 4

2.3.2 Automatic Patching and Upgrades .......................................................

2.3.3 User Desktop and Files .......................................................................

3 Security Systems in Windows 2000......................................................................5

3.1 Security Configuration with MMC ...........................................................

3.1.1 How Security Settings Flow................................................................ 6

3.1.2 Using the Security Configuration and Analysis Console............................ 8

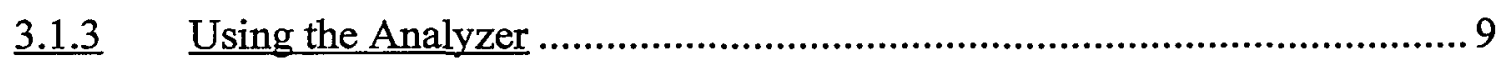

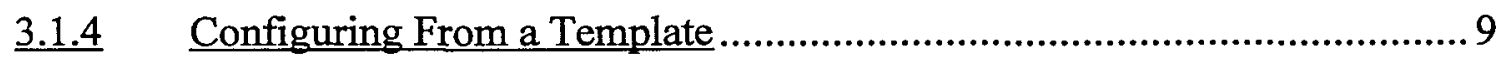

3.1.5 Managing Templates......................................................................... 10

3.1.6 Using the Local Security Policy Console................................................ 11

3.1.7 Using the Group Policy Console .......................................................... 12

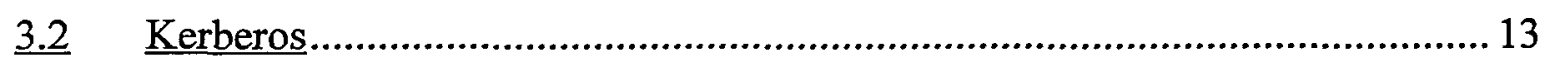

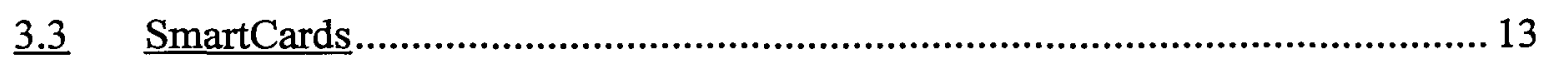

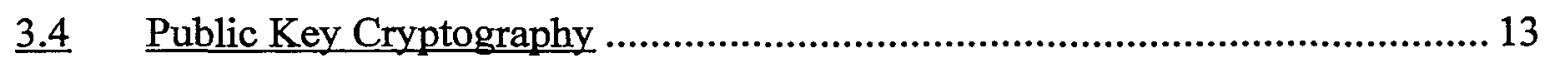

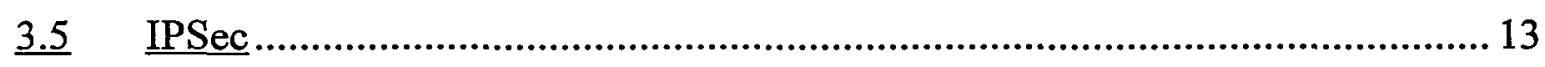




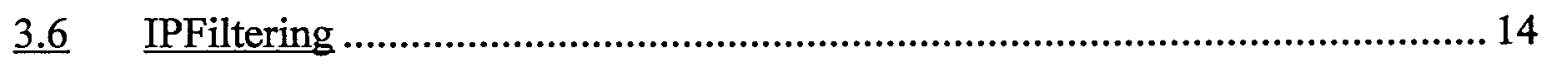

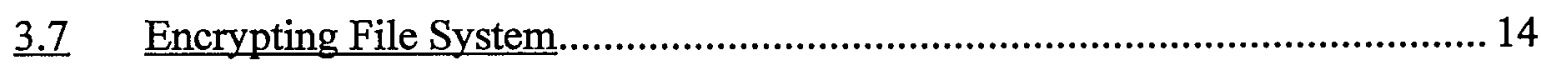

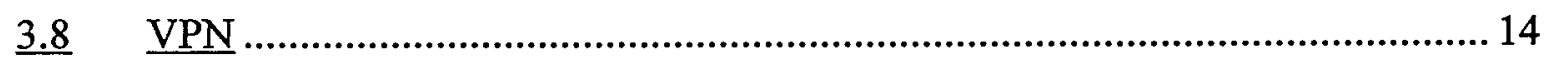

4 Securing a Windows 2000 Workstation.................................................................... 14

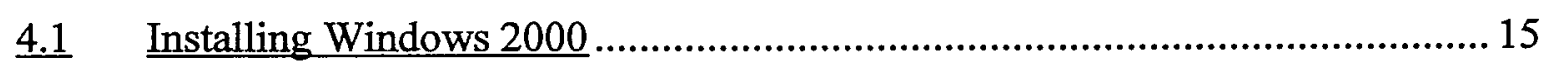

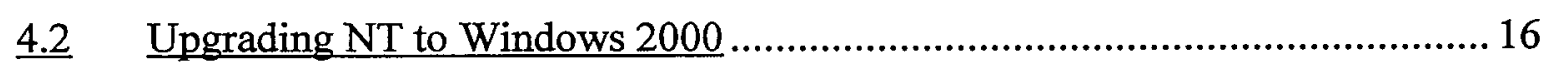

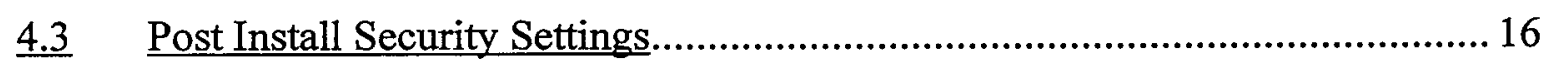

4.3.1 NTFS File Systems ......................................................................... 19

4.3.2 Security Configuration and Analysis..................................................... 19

4.3.3 Disable Unneeded Network Services...................................................... 20

4.3.4 Disable or Delete Unnecessary Accounts .............................................. 20

4.3.5 Set Directory Protection ......................................................................... 21

4.3.6 Restrict Remote Access to the Registry.................................................. 21

4.3.7 Set Protections on Registry Keys .......................................................... 22

4.3.8 Restrict Anonymous Access to the LSA .................................................2 22

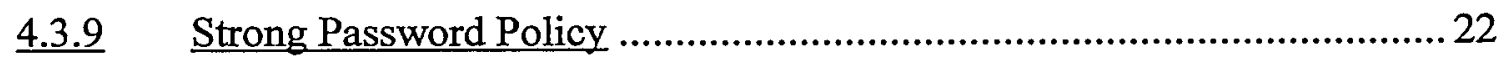

4.3.10 Set the Account Lockout Policy .............................................................. 23

4.3.11 Configure the Administrator's Account.....................................................2

4.3.12 Remove any Unnecessary File Shares .................................................... 23

4.3.13 Set Appropriate Protections on Necessary Shares................................... 24

4.3.14 Install Antivirus Software .................................................................... 24

5 Securing a Windows 2000 Domain Server ............................................................. 24

$\underline{5.1}$ Installation of Internet Information Server (IIS) software................................2

5.2 Post Install Security Settings..................................................................... 25

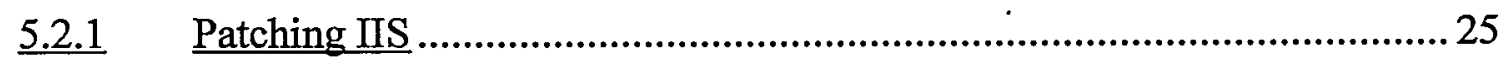


5.2.2 Set Appropriate Web Directory Permissions .......................................2

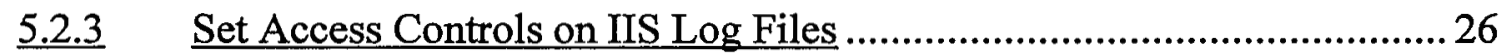

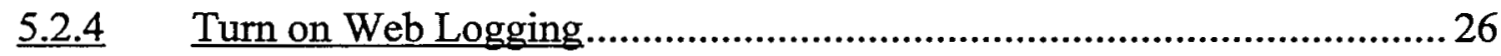

5.2.5 Turn on Secure Sockets Layer Encryption............................................. 27

5.2.6 Remove All Sample Applications .........................................................2 27

5.2.7 Remove the IISADMPWD Virtual Directory ........................................28

5.2.8 Remove the IISADM Virtual Directory .................................................. 28

5.2.9 Remove Unused Script Mappings ....................................................... 28

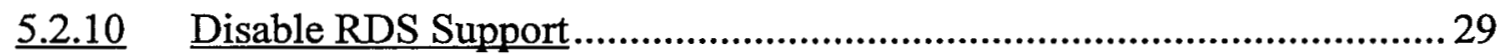

6 Maintaining Security Configurations .................................................................29

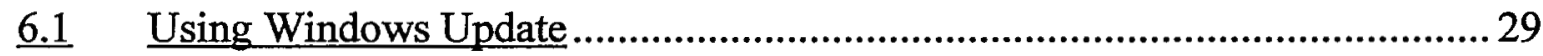

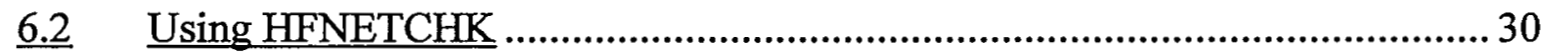

6.3 Using Critical Update Notification.............................................................. 30

6.4 Using Microsoft Security Bulletins .................................................................. 30

6.5 Microsoft Personal Security Advisor ………….............................................. 31

6.6 Microsoft Security Checklists ......................................................................... 31

I References..................................................................................................................... 31

Appendix A - Using HFNETCHK Update Manager ........................................................ 32

Appendix B - - Using Ochain ....................................................................................................... 33

Appendix C-DOE Login Banner........................................................................................ 35

Appendix D - Included Security Configuration Manager Templates ......................... 37

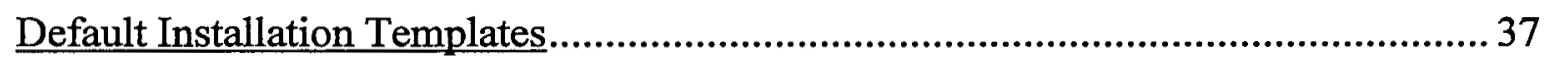

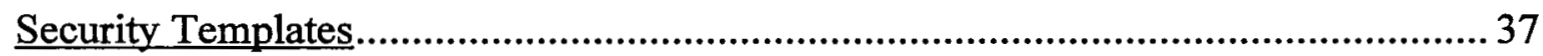

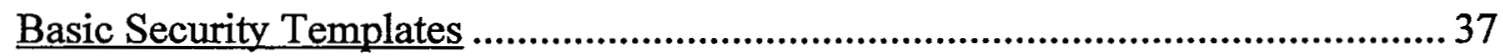

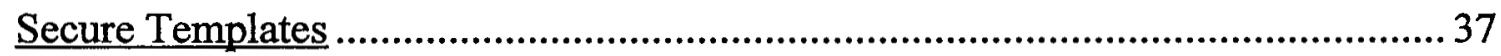




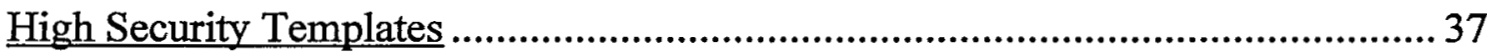

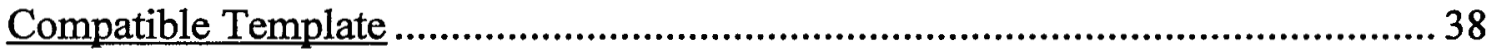

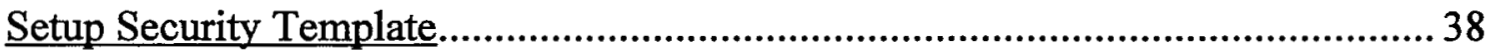

Dedicated domain Controller Template ……...........................................................38

Appendix E-CIAC Security Configuration and Analysis Template..........................39

Account Policies/Password Policy.................................................................................. 39

Account Policies/Account Lockout Policy.................................................................... 40

Account Policies/Kerberos Policy .................................................................................. 40

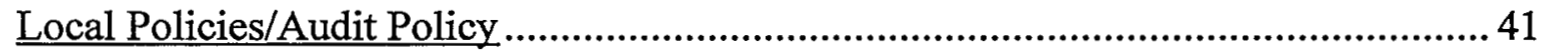

Local Policies/User Rights Assignment ..................................................................... 42

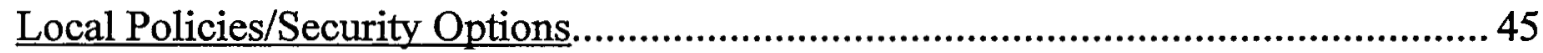

Event Log/Settings for Event Logs........................................................................ 51

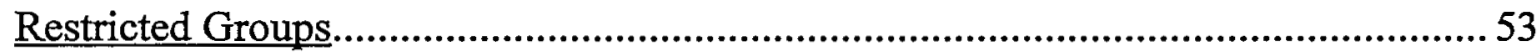

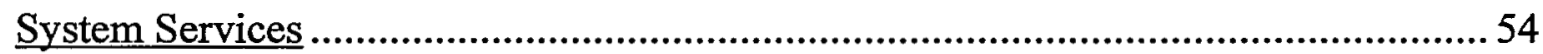

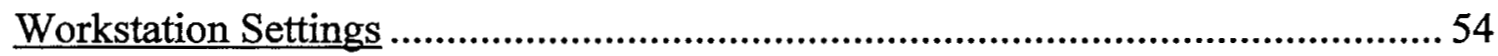

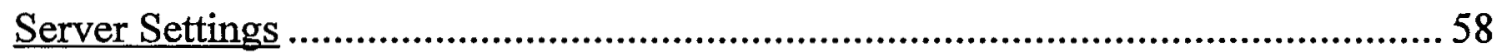

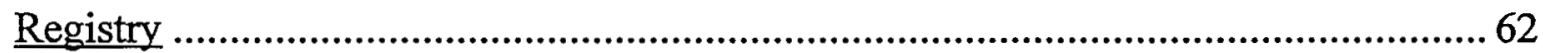

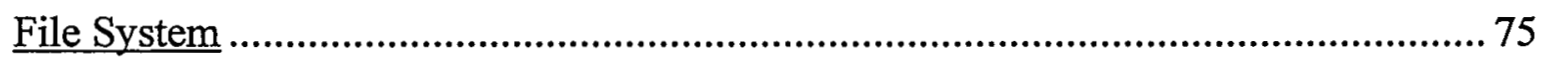

Appendix F - Group Policy Settings VS. Registry Keys ............................................ 113 


\section{OVERVIEW}

As the threat to computer systems increases with the increasing use of computers as a tool in daily business activities, the need to securely configure those systems becomes more important. There are far too many intruders with access to the Internet and the skills and time to spend compromising systems to not spend the time necessary to securely configure a system. Hand-in-hand with the increased need for security are an increased number of items that need to be securely configured. Windows 2000 has about seven hundred security related policy settings, up from seventy two in Windows NT.

While Windows 2000 systems are an extension of the Windows NT 4 architecture, there are considerable differences between these two systems, especially in terms of system and security administration.

Operational policy, system security, and file security are other areas where Windows 2000 has expanded considerably beyond the domain model of Windows NT 4. The Windows NT 4 Domain model consists of domains of workstations that, with a single login, share resources and are administered together. The database of user settings and credentials resides in the domain server. Domains can trust other domains to expand the sharing of resources between users of multiple domains. On Windows 2000 , the domains still exist but multiple domains that share trust are combined into Domain Trees and Domain Forests depending on how the logical namespace is divided. These trees and forests are combined under a new object called Active Directory. Domains themselves are broken down into Organizational Units. As such, there are more levels at which security policies can be set and for which information sharing can be controlled.

Keep in mind that Active Directory, while it is in a superior position in a domain hierarchy, is not a super domain. It is a very different thing. Active Directory is essentially just a database for company wide information. It is a place where you go to get information rather than having that information pushed to you. That database can include user authentication information and any users authenticated at the Active Directory level have access to all the domains below them. And while security policy information can be set at the Active Directory level, it cannot be pushed onto user workstations from there. Pushing of settings and software can only be done from the Domain and OU levels.

The design of an Active Directory is not a trivial operation and should not be done without careful consideration and planning. The biggest problem with an active directory is that it must be designed and implemented from the top down. After a root Active Directory Domain is created, it is not possible to rename it or graft it onto a higher level Domain. The only way to do that is to define a new Root Domain with new subdomains below it and then to migrate all the workstations from the old Domains to the new ones. Information for designing an Active Directory Domain is not in this document.

Each domain under Active Directory must share a single namespace. That is, the name of every machine in a domain must share the same right hand side of the domain name. For 
example, a1.physics.llnl.gov and b2.physics.llnl.gov can both reside in the physics.llnl.gov domain.

Root domains and their logical subdomains form a Domain Tree. Each Domain Tree shares a contiguous namespace. For example, if the root domain is llnl.gov, subdomains could be engineering.llnl.gov, physics.Inl.gov, and chemistry.lnl.gov. However comp.argonne.gov could not be a subdomain. Engineering could be further subdivided into the subdomains mechanical.engineering.llnl.gov, electrical.engineering.llnl.gov, and computer.engineering.llnl.gov.

Alternately, mechanical, electrical, and computer could be Organizational Units (OU) within the engineering domain. An Organizational Unit is a container in a domain for user and machine accounts, and services. Computers within the mechanical engineering OU share the engineering.llnl.gov namespace, not the mechanical.engineering.llnl.gov namespace as they would in a subdomain. The same is true for the other engineering OUs. Administration of an Organizational Unit is much like administration of a domain without having to create a separate domain. Administration of Organizational Units can be delegated to other administrators to spread the administration job without giving these administrators access to the entire domain.

This hierarchy of domains/subdomains/organizational units forms an equivalent hierarchy of security domains or containers where security settings on a container (stored in the container's database) are applied to all objects within a container. Security settings at outer domains filter down to the interior subdomains, organizational units, and eventually to the individual workstations.

Operational policies and security settings are placed on domains, subdomains, or organizational units using Group Policy. Local Security Policy is used to make settings that are unique to an individual system. When you attempt to get access to something on a system, Group Policy is applied first and then Local Group Policy. Thus, Local Group Policy can increase the security on an object but not decrease it.

With the increased granularity in security settings comes a lot more things to set. Combine this with the hierarchy of security domains and an administrator has a huge number of items to analyze and set. Luckily, with this increase in settings comes a group of editors for setting these values, including templates of settings that can be applied with a single command. All of these settings are accomplished with plug-ins to the Microsoft Management Console.

The Microsoft Management Console (MMC) was introduced in Windows NT 4 as the manager of the Internet Information Server and as the console of the Security Configuration and Analysis manager. The MMC is simply a program that supplies the visual interface for various snap-ins that are used to manage a system. For example, Group Policy is an MMC snap-in console for managing Group Policy. Some snap-ins can only show settings while others can change settings on a system. The snap-ins that you will use to configure a Windows 2000 system are:

- Security Configuration and Analysis 
- Group Policy

- Local Security Policy

Other tools for configuring a system are:

- reg.exe - A command line tool which can be used to set policy from within a script.

- hfnetchk.exe - A tool to detect and list the state of patches on a system.

- secedit.exe - A command line tool for applying security templates from a script.

- regedit32.exe - A general purpose tool for editing the registry.

- Critical Update Notification - A service that automatically checks for the existence new security patches.

- Windows Update - A web based service for installing security patches.

\section{Remote Management Considerations in Windows 2000}

Windows 2000 has several new remote management capabilities that security managers need to be aware of. These include Domain level security policies set with Group Policy, Automatic system installation and upgrades, and automatic software installation and upgrades. From a management point of view, these capabilities considerably reduce the amount of time necessary to setup and maintain a large number of systems. From a security point of view, these capabilities create single points of failure that can be used to compromise or take down the whole network.

For example, if a virus infected application is placed on the domain server as an application to be installed on all systems, the update manager will dutifully infect every computer in the network. If a backdoor program were added to the system installer, every new system would be installed with the backdoor in place. If a mistake is made in a group policy, that same mistake now exists on every machine in the domain.

The result is, keep the domain server and management station extremely secure and be very careful with applications to be pushed to every system. Security policy settings at the higher levels should be more global in nature, and should be very straight forward so that the implications are well understood. More restrictive and complicated policies should be done at a lower level, such as at the OU, where the implications are better understood because the administrators better understand the machines they are directly maintaining.

\subsection{Domain Security Settings with Group Policy}

Using the Group Policy Editor snap-in of the MMC, security policies can be set that apply to the whole domain. Be careful which policies you set at this level as they must be of the one-size-fits-all type. Any policies that are different for different Organizational Units should not be set at the domain level.

Some examples of policies that are reasonable to be set at the domain level are,

- Minimum password length

- Password complexity 
- Login banner

Some examples of policies that probably should not be set at the domain level are,

- Login script

- Machines login is allowed from

- User rights

Different organizational units likely have different requirements for the login script. Setting it at the domain level requires that the single domain level script do everything that every Organizational Unit wants. User rights determine what the different types of users can do. Users in a development group need significantly different user rights than a customer service group.

\subsection{AUTOMATIC SYSTEM INSTALLATION}

Using a service called Remote Installation Services (RIS), you can install, over the network, Windows 2000 and any preconfigured applications on a computer with a newly formatted hard drive. To make this work, you must have preconfigured the windows installation and added any installable applications. The easiest way to do this is to configure a standard system the way you want it, with all applications in place, and then use the sysprep utility to create an installable image of that system.

The installable image is placed on the RIS server. A remote computer with a newly formatted hard drive is booted with the RIS client floppy which installs the Client Installation Wizard. The Wizard then connects to the server and controls the installation of the system image.

Great care must be taken here to insure that the system image you create and install on every new computer is secure. Unless you run to the system and pull its network connection, it will be on the network as soon as the system installation is done. If the installed system is not secure and there are no other protections (firewall, etc.) there is a risk that the system will be attacked in its insecure state. We (CIAC) have seen new systems attacked and compromised within minutes of their being placed on the network, as if the intruders were just waiting for a new system to appear.

\subsection{DESKTOP MirRoring AND SOFTWARE INSTALLINATION}

The IntelliMirror service is used to install applications on a user's system. In addition, it can also be used to setup a network where a user's software, data, and desktop settings follow him around the network and are available on whatever computer he logs into.

\subsubsection{Automatic Software Installation}

Automatic software installation part of IntelliMirror comes in two flavors: assigned or published. With assigned software, registry changes are made on a user's system to make the software appear to be on the system. The software name appears in the start menu and the association between document file extensions and the application exists. The application is not actually installed on the computer until the first time it is used. The first 
time the application is used, either by clicking it in the Start menu or double clicking an associated document file, the application is downloaded from the server and installed. Thereafter, the application runs directly from the user's system. If the user deletes or uninstalls the application, it is reinstalled the next time he tries to use it.

Published applications are not automatically installed, but are available for the user to install using the Add/Remove Programs control panel. When a user chooses to add an application, it is downloaded over the network and installed.

\subsubsection{Automatic Patching and Upgrades}

Automatic upgrades are handled in much the same way as automatic software installation. That is, the upgrade file is assigned to each computer and installed the first time the upgraded application is used. If the upgrade is on the system, it is installed the next time the system is started.

While not as risky as full system installations. Automatic system patching and upgrades could also be used to make a system unsecure or unstable. Keep in mind that when doing automatic system upgrades, you are installing the upgrade or patch on all the systems in a domain or OU. Be careful that the patch you are installing is appropriate for all the systems it is being installed on and that it does not open up other vulnerabilities.

\subsubsection{User Desktop and Files}

Another feature of IntelliMirror is its ability to make a user's applications, files, and desktop settings follow him around the network. Whatever machine he logs into is reconfigured, within reason, to be like his home machine, with all applications, data, and settings in place.

\section{SECURITY SYSTEMS IN WINDOWS 2000}

In this section, we will look at the details of the Windows 2000 systems and managers that you can use to secure a system.

\subsection{SECURITY CONFIgURATION WITH MMC}

Most of the security configuration in Windows 2000 is done with Microsoft Management Console (MMC) snap-ins. If you open the Administrative Tools folder within the Control Panel folder all of the control panels found there are actually links to Microsoft Common Console (.MSC) documents which are the configuration "console" files for the MMC. These consoles specify which snap-ins to load when starting the MMC. The following consoles are the most common ones used for security management.

- Security Configuration and Analysis 8systemRooto $\backslash$ system32\secconf.msc

- Security Templates 8 SystemRoot $\backslash$ security $\backslash$ templates

- Group Policy \&systemRoot\&\system32\gpedit.msc

- Local Security Policy \&systemRoot: \system32\secpol.msc 
If you want to modify or create a new console, open the console with MMC using the /a switch. The /a switch puts the MMC into author mode, allowing you to make changes to the console file. You can then add other snap-ins to the console to keep your often used ones together. For example, when developing a template strategy, it is useful to add the Security Templates snap-in to the Security Configuration and Analysis console. In that way you can quickly move between the template editor and the system analyzer within a single console.

\subsubsection{How Security Settings Flow}

Before you can use the security configuration consoles, you need to understand how the security settings flow between group policies, local policies, local settings, security settings databases, and security templates. Because of the way information flows between these different objects, settings you may think you have made may be changed without you knowing it.

When a group policy setting is made on a domain controller, that policy is automatically pushed to the connected client systems whenever they login and again every ninety minutes or so. Those settings overwrite the local policy settings on the client computer. When a machine starts up or a user logs in, the policy settings override any local settings in the registry. They don't change the local settings, they are simply used in place of the local settings if they exist.

There are three, main, policy editor consoles used with Windows 2000: Security Configuration and Analysis, Group Policy, and Local Security Policy. When run on a client machine, both the Group Policy and Local Security Policy consoles save the system configuration information in the database,

\% SystemRooto \security $\backslash$ Database \secedit.s db

Whenever you make a change in a system's local policy, that change is made in both the system's registry and in the database. Note, however, that the Group Policy and Local Security Policy consoles do NOT read the registry when displaying the current settings, they only read the database.

Warning: There is a problem here in that the Group Policy and Local Security Policy editors could indicate that a system has some required settings and the actual settings could be completely different. If a user changes some registry settings using RegEdit or by double clicking a .reg file, he could change security settings in the registry and these two consoles would not know it. Before trusting the results of the consoles, perform a system shutdown and reboot to force the database to be updated.

The Security Configuration and Analysis console works differently. While it does save security settings in a database, when you run the analyzer function, it examines and displays the real registry settings. If you don't run the analyzer function, the data you see is from the database which was created the last time you ran analyze. The database is, 
The main drawback of the Security Configuration and Analysis console is that you cannot make individual registry changes with it, you can only apply all the settings in a template.

Now, all of this may seem confusing, but consider the following example. There are two registry values in the WinLogon key that create the login banners, one for the banner caption and one for the banner body.

Key:

HKLM \SOFTWARE \Microsoft $\backslash W i n d o w s ~ N T \backslash C u r r e n t V e r s i o n \backslash W i n L o g o n$

Values:

LegalNoticeCaption = "The caption text."

LegalNoticeText = "The body of the banner."

Here, HKLM stands for HKEY_LOCAL_MACHINE.

In the absence of any policy settings, these two keys define the title and contents of the banner. On Windows 2000 , there is a second pair of values in a different registry key.

Key:

HKLM \SOFTWARE \Microsoft $\backslash W i n d o w s \backslash$ CurrentVersion $\backslash$ Policies $\backslash$ system

Values:

LegalNoticeCaption = "The local policy caption text."

LegalNoticeText = "The local policy body of the banner."

These are the local policy registry keys. Whenever someone logs into the system, if either of these keys contains a string value, that value takes precedence over the values in the WinLogon key. That is, any defined values in the Policies keys override similar values in the system's or application's keys. In this way, a local policy overrides a local setting.

If a group policy is set for a domain, whenever the group policy values are pushed out to a system, those values actually overwrite the values in the Policies keys. In this way, the group policy overwrites local policy, which overrides local settings.

These registry values determine what is actually displayed in the login banner. If you start the Local Security Policy editor and open Local Policies/Security Options in the tree view, you see the two policies listed below,

Message title for users attempting to $\mathrm{log}$ on

Message text for users attempting to log on

The values displayed for these policies are the values from the database, not from the registry. If you change any of these values, the change is applied to the database and to the values in the Policies registry key. However, there is nothing to prevent Active Directory or a user with regedit (the registry editor) from changing those keys after they have been set with the security consoles. See Appendix F for the location of all the registry settings used by Group Policy. 
We have seen the values in the database change to the values in the registry without us actually doing it, so there is a system process that compares the database to the registry and makes changes as needed. This process appears to run at boot time and every so often during the day.

Basically, what we are saying here is to not depend on the Local Security Policy or the Group Policy consoles to tell you what the current policy is on a system. You must use the Security Configuration and Analysis console and perform an analysis of your system before you can declare the state of the settings on that system.

\subsubsection{Using the Security Configuration and Analysis Console}

The Security Configuration and Analysis console is the primary console document for configuring the security of a system. This console has two capabilities. First, it analyzes a system's security settings and compares them to a template. Any settings that do not match the template are marked. Second, it applies all the security settings in a template to a system, making hundreds of settings in a single pass.

The Security Configuration and Analysis console makes security settings in the following areas:

- Account Policies

- Local Policies

- Event Log

- Restricted Groups

- System Services

- Registry

- File System

An explanation of each of the individual policy settings is in Appendix E. The Account Policies area consists of two subareas:

- Password Policy

- Account Lockout Policy

- Kerberos Policy

The Password Policy subarea consists of settings of password length, complexity and age. The Account Lockout subarea sets the number of failed logins that will lock out an account, the duration of the lockout, and the time to reset the account. The Kerberos policy is available if you are using Kerberos authentication. It contains several timeouts for the ticket granting service.

The Local Policies area consists of three subareas:

- Audit Policy

- User Rights Assignment

- Security Options

The audit policies include login/logoff, policy changes, and privilege use. Auditing of file access is done on a directory by directory basis. User rights are the privileged things a 
user is allowed to do, such as login remotely or shutdown a machine. Security Options gets just about everything else that cannot be classified in the previous subareas.

The Event Log area contains all the settings for the Application, Security, and System event logs. The settings include the size of the logs and access to them.

The Restricted Groups area allows you to make two settings on the security-sensitive groups. You can set the members of a group and you can set what groups a group is a member of. The restricted groups are,

- Administrators

- Backup Operators

- Guests

- Power Users

- Replicator

- Users

The System Services area allows you to set which services are allowed to run in a system and when they are to run (at boot or when needed). In a single computer, system services are configured using the Services control panel. Using the System Services policy, you can override any of the control panel settings.

The Registry area sets access to different parts of the system registry. Different keys within the registry can have their access restricted to certain individuals in the same manner that you restrict access to files.

The File System area allows you to set the access security on files or directories.

\subsubsection{Using the Analyzer}

The console maintains two tables in the database, one containing the state of the system the last time the system was analyzed and a second containing a template. To analyze a system, choose Security Configuration and Analysis in the tree view and choose the Analyze Computer Now action. When the analysis process is complete, all settings that are defined in the database and that match the actual setting have a green check on the setting's icon. Those that are defined in the database and that do not match the actual setting get a red $\mathrm{x}$ on the icon. Those settings that are not configured in the database show a plain icon.

\subsubsection{Configuring From a Template}

To configure a system using the settings in the template, choose Security Configuration and Analysis in the tree view and choose the Configure Computer Now action. All of the settings in the current template are made on the computer system. 


\subsubsection{Managing Templates}

To load a template, choose Security Configuration and Analysis in the tree view and choose the Import Template action. The template you choose is added to the template currently in the database. Items defined in the new template replace those previously in the database. However, items that are defined in the database but that are not defined in the new template are retained in the database. Choosing the Export Template action writes the current template into a template file.

If you want the database to contain only the imported template, you must first create a new database and then import the template. You create a new database using the Open database action and specifying a database name that does not exist. As part of the database creation process, the console asks for a template.

The templates themselves are text files and can be opened and edited. While changing values in a template is not straightforward, deleting sections is. If you want a template that contains only the file access parts of an existing template, it is not difficult to figure out which part of the template deals with files and to delete the others. Watch out for string definitions in the templates as the strings are used in the templates themselves and should not be deleted.

To change a template using the Security Configuration and Analysis console, select the security setting you want to change and either double click it or choose the Security action. The Analyzed Security Policy Setting dialog box opens. The contents of the dialog box depend on the type of security setting you are making. Your first choice is to determine if you want to include this setting in the template. Check the "Define this policy in the database." check box if you want to include this option in the template. After that you set whatever setting you want the security setting to have and click OK. The setting is now in the template database and is compared to the current value of the security setting. The setting is not applied to the actual security setting until you choose to configure the computer from the template.

This console is often combined with the Security Templates console, which is a security template editor and which contains eight built-in templates designed to provide different levels of security for workstations or servers. The templates are stored in the following directory.

ofsystemRooto \security $\backslash$ templates

The included templates have three levels of security,

- Basic

- Compatible

- Secure

- Highly Secure

- Dedicated Domain Controller

The templates come in versions for a workstation, server, and domain server. 
The basic templates apply the Windows 2000 default security settings to all security areas except those pertaining to user rights. The basic templates are available primarily to undo the application of one of the more secure templates. They do not modify the user rights areas because these areas are often modified by the installation of applications and to reset them to the default would likely break the applications.

The compatible templates decrease the security of the Users group to the point where they can run applications not certified for Windows 2000. These settings are equivalent to the Users setting in Windows NT 4. The default way to run non certified applications in Windows 2000 is to put the users in the Power Users group.

The secure templates implement the recommended security settings for all areas except files, folders, and registry keys.

The highly secure templates make security settings for network communications that limit network communications to other Windows 2000 computers. Computers with the highly secure settings will not be able to communicate with computers running Windows 95,98 , or NT.

The dedicated domain controller template increases the security on a domain controller which does not run any server based applications. The default configuration of a Windows 2000 domain controller is reduced to allow server based applications to run. If you do not run any server based applications on the domain controller, you can increase its security with this template.

\subsubsection{Using the Local Security Policy Console}

The Local Security Policy console sets security policy on the local machine. That is, it sets values in the Policies registry key.

There are four areas managed with the Local Security Policy console,

- Account Policies

- Local Policies

- Public Key Policies

- IP Security Policies on Local Machine

Account policies and local policies are the same as are in the Security Analysis and Configuration console. Public key policies contains a subarea Encrypted Data Recovery Agents. Values in that subarea contain encryption certificates used for encrypting data.

The IP Security Policies on Local Machine area contains security rules for communicating with other machines. That is, which machines require encrypted connections and what to do if a machine asks for an encrypted connection.

The console can import or export a template, and can use the same templates as are used by the Security Configuration and Analysis console. The biggest difference between the Security Configuration and Analysis and the Local Security Policy consoles is that when a template is imported, it is immediately applied to the registry. Also, while it can use the 
same templates as are used by the Security Configuration and Analysis console, it only applies those parts that are in the four areas listed above.

In addition to using templates, you can set individual values using this console without having to apply a whole template. To set or change policies, select the item you want to change and choose the change you want to make from the Action menu.

\subsubsection{Using the Group Policy Console}

The Group Policy console sets group policy on a domain server and local group policy on a workstation. The Group Policy has two main areas.

- Computer Configuration

- User Configuration

Within both areas are three subareas, however the contents of the subareas are different depending on which of the major areas is selected.

- Software Settings

- Windows Settings

- Administrative Templates

Under Computer Configuration/Software settings, there are no default values on a workstation. Under Computer Configuration/Windows Settings are,

- Scripts

- Security Settings

The scripts subarea contains a place where you can specify startup and shutdown scripts. The Security Settings area is identical to that in the Local Security Policy console.

The Administrative templates area does not really contain templates but individual settings that are pushed out to a workstation. The area contains four subareas,

- Windows Components

- System

- Network

- Printers

The Windows Components subarea contains settings for applications installed along with Windows 2000 such as Internet Explorer and Netmeeting. The System subarea contains settings for logon, Disk Quotas, DNS Clients, Group Policy, and Windows file protection. The Network subarea contains settings for Offline files and Network and dialup connections.

Under the User Configuration/Software settings, there are no default values on a workstation. Under Windows Settings, there are three subareas,

- Internet Explorer Maintenance

- Scripts

- Security Settings 
Internet Explorer Maintenance contains settings for the default user's Internet Explorer's settings. The Scripts area contains a place for setting logon and logoff scripts and the Security settings area contains no values for a workstation.

The Administrative Templates area contains settings for,

- Windows Components

- Start Menu \& Taskbar

- Desktop

- Control Panel

- Network

- System

The settings contained here include those that allow you to control the user's desktop, start menu, and what settings the user can make in the control panel. For the most part, these are administrative control rather than security items.

\subsection{Kerberos}

The default authentication and access control mechanism for a pure, Windows 2000 network is Kerberos version 5. Other authentication mechanisms are available for mixed environments with older versions of Windows such as LanManager (LM), NT LanManager (NTLM), and NTLM v2. The LM protocol is only needed for older systems and should be avoided if possible because the authentication handshake and password are not encrypted.

\subsection{SMARTCARDS}

As an alternative to Kerberos, smartcards can be used for user authentication and access control. Use of smartcards does require more hardware, including the cards themselves for each user and a card reader at each machine.

\subsection{Public Key Cryptography}

Public key cryptography is the foundation for many of the security services available on Windows 2000, including Kerberos, smartcards, IPSec, VPN, and others.

\subsection{IPSEC}

IPSec (IP Security) is an extension of the IP networking protocol that adds encryption and authentication to network packet traffic. The security is added at a low level in the protocol stack so that applications do not need to know anything about it. As far as they are concerned, packets are sent and received with clear data. It is the low-level security systems that do the encryption and decryption of packets to protect them while they are traversing the Internet. 


\subsection{IPFILTERING}

IP Filtering is a setting in Windows 2000 networking where you can explicitly set which IP protocols and ports are going to accept incoming packets. For IP Filtering to work, you must specify every port on your computer that is going to be open to receive incoming packets. Much of the effectiveness of IP Filtering is in preventing accidental port openings as disabling or removing unneeded services already blocks most ports.

\subsection{ENCRYPTING FILE SYSTEM}

An encrypting file system is available on Windows 2000 . With it, you may encrypt a single file, a whole directory or a whole disk drive. Protected files are encrypted with an encryption key that is encrypted with the user's key and, optionally, a recovery key and kept with the file. When a file is accessed, the key is decrypted and used to decrypt the file "on the fly". That is, files are not decrypted to disk, but are decrypted sector by sector as the sector is needed. When the file is written back to disk, the sectors are encrypted before writing. Keep in mind, that if you Save As a file to an unencrypted directory the file will not be encrypted. Only if it is saved back to the original encrypted file name or into an encrypted directory is it encrypted before saving it to disk.

In general, you should encrypt whole directories so that temporary files created by applications and written to disk are also encrypted. You should also consider encrypting any temp directories on a system as they are also used by applications for temporary file storage.

\subsection{VPN}

Virtual Private Networking is essentially a way to make a remote workstation appear to be on an internal company network. It does this by creating an encrypted, virtual pipe from the workstation to a machine on the internal network where the pipe is decrypted and the packets are placed on the internal network. As far as the remote machine and the internal machines are concerned, the remote machine appears to be directly connected to the internal network.

VPN is primarily used by people using their laptops on travel to access company records or people working at home who must access internal company records. Care must be taken with laptops that implement a VPN connection to an internal network that the VPN connection is not setup to automatically connect with a stored password. If that was the case, a stolen machine would give the thief access to the internal company network by simply turning it on.

\section{SECURING A WINDOWS 2000 WorkSTATION}

Windows 2000 Workstation is optimized for a desktop workstation. That is, foreground applications have higher priority and there are not so many server type functions available. 
The best way to install Windows 2000 is on a freshly formatted hard drive. This type of installation eliminates all legacy settings and applications that may be reducing the efficiency of the system. Reformatting a hard drive also re-writes and realigns all the tracks on the drive that may have moved slightly because of heat and ageing of the drive. A problem with such an installation is that all your applications and settings are lost and must be reinstalled or reentered.

The next best way to install Windows 2000 is a clean install into an existing disk partition. You do this by placing it in a different directory from the existing Windows system (for example, /winnt 2 instead of /winnt). You still loose most of your settings and you must reinstall all of your applications but most of the application data files (such as e-mail files, address books, and favorites lists) are not lost.

Lastly, you can perform an upgrade of an existing Windows system to Windows 2000. This type of upgrade preserves all of your settings and applications, including your file permissions for the system and other directories. If you are upgrading from Windows NT 4, the Windows 2000 installer does not normally change your existing security settings to what might be optimal for Windows 2000 .

\subsection{INSTALLING WINDOWS 2000}

The basic installation of Windows 2000 onto a clean hard drive or a clean installation onto an existing system is relatively straight forward. You simply boot the installation program and follow the instructions.

1. Disconnect the system from the Internet if it is connected. The process of installing a new system opens several security holes that must be closed before the system can be put on the network.

2. Start the Windows installer.

Place the Windows installation CD into the drive and reboot. If your system does boot the installation $\mathrm{CD}$, you must start the installer using the installation floppies.

\section{Follow the directions for a new installation.}

4. Set the installation partition.

When the system asks you what partition to install windows into, you have the choice of deleting, creating, or using the existing partitions. If you want a clean installation onto a formatted disk, delete the partition where you want to install the system and then recreate it. Recreating the partition causes it to be formatted. Note that formatting the partition deletes everything on it.

5. Set the file system in the partition to NTFS.

The NTFS file system is required in order to apply protections to the files and directories. There is no file system protection for a FAT or FAT32 file system.

6. Choose the location for the windows directory.

If you are installing onto a clean disk, accept the default directory name (/winnt). 
If you are doing a clean install onto an existing disk, choose a different name for the directory (such as /winnt2). Later, you can delete the old windows directory.

\section{Use a strong Administrator password.}

Make sure the administrator's password is a strong password with adequate length ( 8 characters) and complexity (mix of text, numbers, and punctuation).

\section{Follow the directions to complete the installation.}

\subsection{Upgrading NT To Windows 2000}

Upgrading an existing Windows NT 4 system to Windows 2000 proceeds much like an installation onto an existing partition, with the difference that you install into the existing windows directory.

1. Disconnect the system from the Internet if it is connected.

The process of installing a new system opens several security holes that must be closed before the system can be put on the network.

2. Start the Windows installer.

You can do this by booting the system with the old system, inserting the Windows 2000 installation $\mathrm{CD}$ and choosing to upgrade the existing system. You can also boot the system as before using the installation CD or floppies and choosing to upgrade the existing system.

3. Set the file system in the partition to NTFS.

The NTFS file system is required in order to apply protections to the files and directories. There is no file system protection for a FAT or FAT32 file system.

\section{Choose to upgrade the existing Windows directory.}

\section{Follow the directions to complete the installation.}

\subsection{Post Install Security Settings}

After installing Windows 2000 , you must make several updates before the system can be safely put onto the Internet. These updates include installing the latest service pack and any post service pack security updates.

If possible, copy the service pack and updates onto a $\mathrm{CD}$ and use that for installation. In this way, the security holes are closed before a system is placed on the Internet. If it is not possible to get a $\mathrm{CD}$ of the service pack, you can place the system on the Internet, download, and install the service pack directly from the Microsoft Windows Update website (windowsupdate.microsoft.com). Note that there is a link to the Windows Update website on the Start menu. Because the system is not completely patched yet, connection to the Windows Update website and patching of the system must be done immediately after connecting the system to the Internet. If the system is going to be left for some time 
before the installation of the service pack and patches are complete, you should disconnect it from the Internet.

1. Connect the system to the Internet.

Plug the network cable into the computer and set the Networking properties for your system on your local subnet. You must set the computer name, IP address, gateway, and nameservers, or you can specify a DHCP server where your system can get that data.

Warning: If you are not immediately going to install the service pack and patches, pull the network cable out of the back of the computer to remove it from the Internet. Reinsert the network cable only when you are ready to continue.

2. Connect to the Windows Update website. (http://windowsupdate.microsoft.com) and click Product Updates.

When you connect to the Product Updates page on the Windows Update website, the server will ask to install a Java program on your system to evaluate what updates you need. When asked, allow that program to be installed and run.

3. Install the latest service pack.

From the list of required updates, select the latest service pack and install it. Some of the updates can be installed together but others must be installed separately and the system rebooted to complete the install before installing something else.

4. Reboot your system when told to do so.

5. Install other updates.

Connect to the Windows update website again and select any required updates and patches. Download and install them. Make a note of the date of the most recent update package. You may need to do steps 4 and 5 several times before you get all of the updates installed.

6. Upgrade Internet Explorer.

Even if you are not going to be using Internet Explorer as your web browser, several programs and system utilities use it, so update it to the latest version. The latest version of Internet Explorer can also be installed from the Windows Update website. In general, you should do a custom installation of Internet Explorer so you can limit the other applications installed along with it. Of special concern is the Outlook Express mail client. If you are not using Outlook Express as your mail client, make sure it isn't installed by the Internet Explorer installer.

7. Reboot the system when told to do so.

8. Run Windows Update again.

Connect to the Windows update Product Updates website again and check that all required patches have been installed.

9. Reboot the system when told to do so. 
At this point, your system is reasonably safe. Next, you need to check for any recent fixes that have not yet made it to the Windows Update website.

1. Go to the Windows Security Site (http://www.microsoft.com/security/).

2. Select Security Bulletins.

3. Filter the bulletins by operating system and service pack. Sort the bulletins by Windows 2000 Professional and the service pack (2) you just installed. See if there are any important security concerns for the system with dates after the date of the latest update package that you installed above.

4. Download and install any hotfixes noted in the bulletins.

Note: Most hot fixes require a reboot after each installation. To install multiple hotfixes and only have to reboot once at the end, download and use the qchain program from the Microsoft website. By running qchain after running all of your installation programs, you can run several installers and only do a reboot after the last installation. See Appendix B more information on qchain.

5. Download the HFNETCHK.EXE program.

The HFNETCHK.EXE program is available in the Windows Security Toolkit on the Microsoft website

http://www.microsoft.com/technet/security/tools/content.asp

This program downloads a list of security patches and information on how to determine if they have been installed.

6. Run HFNETCHK.EXE

Run HHNETCHK.EXE (See Appendix A) when asked to allow the download of an XML file from Microsoft, click yes. Make note of any missing hotfixes.

Note that hotfixes marked as a "Warning" are those where the program cannot determine if they are installed or not. You must know if they were included in the updates.

Note: HFNETCHK.EXE can be run on one machine but gather patch information for all machines on a Windows domain (you must run it as the domain administrator). See Appendix A for more information on hfnetchk.

7. Install any required hotfixes.

Find the hot fix bulletins on the security page, download, and install them.

8. Reboot the system again just for good measure.

Many Windows installations need to change files that are in use and can't be replaced while the system is running. These files are placed in a special queue 
and are replaced at system startup (this is why Windows is always telling you to reboot the system).

\subsubsection{NTFS File Systems}

The NTFS file system is usually specified during installation of the system. If you are doing an upgrade of an existing system you may have a FAT or FAT32 file system. The NTFS file system is needed in order to be able to do file and folder level access permissions. To check a disk to see what type of file system it contains, open My Computer, right click on a disk drive and select properties. On the general tab of the properties dialog box it should say File system: NTFS. If it does not, you need to run the convert utility to convert the file system to NTFS. The convert utility will convert a FAT or FAT32 file system to NTFS without having to reformat the drive. While it should not damage any files on the drive, it is a good idea to backup any critical files just in case. To run the convert utility, open a command window and type the following command:

convert drive: /fs:ntfs

where drive is the drive letter of the drive you want to convert. If it cannot lock the drive because it is in use, it will do the conversion the next time you reboot your system.

\subsubsection{Security Configuration and Analysis}

Run the Security Configuration and Analysis console in the Control Panels/Administrative Tools directory and use it to apply the CIAC template to your system. Using this tool sets most of your required security settings. The list of settings in the CIAC template is in Appendix E.

1. Start the Security Configuration and Analysis console. Look for it in Control Panel/Administrative tools. You must run the tool as local Administrator on the machine you are going to configure or as the Domain Administrator.

2. Open the CIAC template. Select Security Configuration and Analysis in the tree view and choose the Import Template Action. Find the CIACWorkstation or CIACDomainController templates, depending on which kind of a machine you are configuring. And open it.

3. Analyze the system.

With Security configuration and Analysis selected, choose the Analyze Computer Now action. All the objects in the template will be checked and compared to the actual settings on the system.

4. Examine the proposed changes.

Examine any objects listed in the console that have a red $\mathrm{X}$ on them as they do not match the template and will be changed. Make sure the proposed changes are consistent with the planned use of the system. 


\section{Apply the settings in the template.}

With Security Configuration and Analysis selected, Choose the Configure Computer Now action. When this is done, your computers settings should match those in the template. Running Analyze Computer Now again should show no differences between the computer settings and the template.

\subsubsection{Disable Unneeded Network Services}

Any network service that is running on a system can provide a hole that an intruder can use to break in and take control of your system. Thus, any network services that you are not using should be disabled or uninstalled from your system. Of primary importance is the Internet Information Server (IIS) which provides a web, mail, and news server for the network. Most workstations do not need any of these services so the IIS can be uninstalled if it was installed by the system installer.

To see what services are running on a system, open the Control Panel and double click on Administrative Tools, and then double click on Services. From the services control panel, you can start or stop a service, set when a service starts, or disable it. For service startup you can pick one of the three options.

- Automatic - The service starts when the system boots.

- Manual - A program can start the service when it needs it.

- Disabled - A service cannot be startup.

Alternately, from the Security Configuration and Analysis console, choose the System Services area to see all the running system services plus you can see which were set by the template and which are still at their default values.

\subsubsection{Disable or Delete Unnecessary Accounts}

The unnecessary accounts consist primarily of the Guest account and any of the Anonymous login accounts created for the IIS server or other services. The first account to get rid of is Guest. At the minimum, it should be disabled. To further protect a system, replace the Everyone group with the Authenticated Users group everywhere in the file system. The Authenticated Users group is the same as Everyone but without Guest and without Anonymous.

If you are using the IIS, you probably have a guest like account called IUSR_machinename where machinename is the name of the machine you are working on. This account is used for the initial connection of a person to a web server. Everyone who connects to a web server on a machine first becomes IUSR_machinename. Ater that, if he attempts to download web files from a protected directory he must authenticate and become a real user of the system. If you plan to allow anonymous access to a web server, be sure the IUSR machinename account has access to all the files you want him to have access to and to no other files. If you are not using a web server on your machine, remove this account. 
Another anonymous account is the IWAM_machinename account. This is created by the Web Application Manager for the same reason as the IUSR machinename account is created for IIS. Web applications are services that are accessed through the Web server but that run as a separate process. The IWAM_machinename account is used for the initial connection to the process.

\subsubsection{Set Directory Protection}

The default directory protections set in Windows 2000 are relatively secure, compared to previous versions of Windows. If you do a clean installation of Windows 2000 all the directory permissions will be set to these default values. If you upgrade from Windows NT 4, the installer will keep your previous permissions and you will need to adjust them to raise the security of your system.

Templates containing the default directory permissions for Windows 2000 are in the following files,

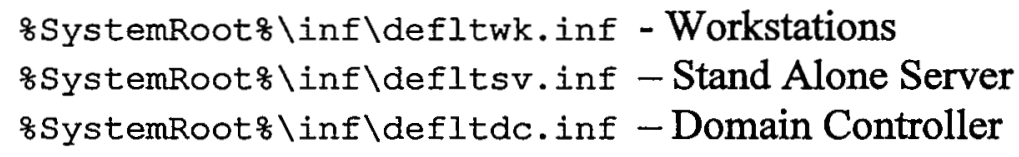

Either of these files can be opened by the Security Configuration and Analysis console and used to analyze your system. Do not apply these templates as they contain many more settings than the file system settings. To set only the file system options, copy the template and edit is with a plain text editor such as Notepad. Remove all the sections that do not have to do with the filesystem. Be careful you don't delete any strings defined in the template for use in the template. You then start the Security Configuration and Analysis console, create a new database with the Open database command and then import the new template. You must create a new database because any settings that are not set in the template are remembered from previous templates you have applied to this system.

\subsubsection{Restrict Remote Access to the Registry}

This item is set in the Registry area of the CIAC template in Appendix E. The registry key is,

$$
\text { HKLM \System\CurrentControlset\Control \SecurePipeServers \Winreg }
$$

Set the access control to this key to Administrators full control only. Allow no one else access to this key.

However, some services need access to this key in order to operate. For example, the Spooler and Replicator services need access. You can either add the account name that the service runs under to the access list of the Winreg key or define the AllowedPaths key under the winreg key and add a machine value containing the paths to the keys to bypass security on. This key is not created by the CIAC Template. Create the key, 
Name: machine

Type: REG_MULTI_Sz

Value: System \CurrentControlset\Control\Productoptions

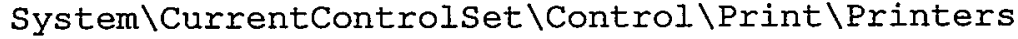
System\CurrentControlset\control \Server Applications System \CurrentControlset \Services \Eventlog

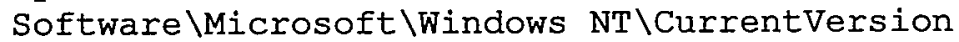

See the Microsoft Knowledge Base article Q155363 for more information.

\subsubsection{Set Protections on Registry Keys}

These settings are in the Registry section of the CIAC template.

\subsubsection{Restrict Anonymous Access to the LSA}

The LSA is the Local Security Authority and contains information about current users and accounts. You should restrict Anonymous access to this key so intruders cannot gain information about a system they could then use to attack that system. To restrict access to the LSA, add the following value to the LSA key.

$$
\text { HKLM \System\CurrentControlset\Control\LSA }
$$

Name: RestrictAnonymous

Type: REG_DWORD

Value: 1

\subsubsection{Strong Password Policy}

These settings are part of the local Account Policy. This password policy is set in the CIAC template. The password policy needs to be strengthened to insure that passwords cannot be guessed by an intruder. Do this by setting the following policies:

- Minimum length: 8

- Password history: 10

- Maximum password age: 180 days

- Password complexity: Enabled

Password history prevents a user from reusing an old password. Password complexity requires that a password not contain the account name and that it contains characters from three of the following groups.

- Lower case letters

- Upper case letters

- Numbers

- Symbols 


\subsubsection{Set the Account Lockout Policy}

These settings are part of the local Account Policy. This account lockout policy is set in the CIAC template. The lockout policy prevents an intruder from using a dictionary attack on a system by locking out an account after a certain number of login failures. A dictionary attack attempts to log on to a users account by trying all of the passwords in a dictionary of passwords, one at a time.

Set the following account lockout policies:

- Account lockout duration: 30 minutes

- Account lockout threshold: 5 invalid logins

- Reset account lockout counter after: 30 minutes

With these settings, an account is locked out after 5 login failures but will be automatically reset after 30 minutes. Note that the Administrator's account cannot be locked out.

\subsubsection{Configure the Administrator's Account}

Because the Administrator account is available on all Windows systems, it is a well known attack point for intruders. It is useful to change the name of the Administrator account (not root or Admin) to something else to make it more difficult for an intruder to attack a system.

You should also enable account lockout for the Administrator account for network logins. Do this with the passprop.exe utility from the Server resource kit. The command to enable administrative lockouts is,

passprop /adminlockout

Note that this does not lockout the Administrator account from console logins. To reverse this setting, use the /noadminlockout switch.

\subsubsection{Remove any Unnecessary File Shares}

File shares consist of two types; those created by the user and administrative shares created by the system. Unlike Windows NT 4, administrative shares cannot be permanently deleted. While you can delete them for the current session, they return the next time the system reboots or the server service is stopped and restarted. Administrative shares are only accessible (read) by the local Administrators, Backup Operators, and Server Operators.

Shares are administered with the Computer Management MMC console in the System Tools $\backslash$ Shared FoldersiShares area. Shares starting with a $\$$ are administrative shares. In this console, you can add or delete user created shares and set permissions on those shares. Remove any user shares that are not needed. 
You can also see the current shares on a system using the following command in a command window.

net shares

You can also delete shares at the command prompt by typing,

net shares sharename /delete

Where sharename is the name of the share you want to delete.

\subsubsection{Set Appropriate Protections on Necessary Shares}

Protecting required shares can be accomplished in two places. You can either place protections on the share, or on the files and folders within the share. It is not necessary to place protections in both places. It is common practice to set the permissions on a share to everyone full access and to then set restrictive access controls on the shared folder itself.

To set permissions on a share, right click the shared folder and choose sharing to display the sharing dialog box. Click the permissions button to see the current access controls on the folder. Change those permissions as necessary. To set permissions on the shared folder, right click on the folder, choose properties and select the security tab. In the properties dialog box, set the access controls on the folder.

The share permissions on administrative shares are read for local Administrator, Backup Operator, and Server Operator and cannot be changed.

\subsubsection{Install Antivirus Software}

With the large number of viruses available today, antivirus software is a must. When using antivirus software, be sure of the following items.

- The antivirus software and virus definitions are up-to-date. Current packages update weekly over the Internet.

- Active virus protection is operating. Active virus protection checks every file when it is accessed and every e-mail message when it is downloaded.

- Scan critical files at startup (boot sector, root directory, system files).

- Scan all files on a weekly basis.

\section{Securing a Windows 2000 DomaIn SeRver}

Installation of a Windows 2000 Server or Domain Server proceeds much like that for a Windows 2000 workstation, with the following exceptions.

- Installation of the Internet Information Server (IIS) software.

- Patching and security settings for IIS.

- Policy configuration using the server policy settings. 


\subsection{INSTALLATION OF INTERNET INFORMATION SERVER (IIS) SOFTWARE}

If this server is going to serve up files using network services such as web, ftp, net news, and e-mail, you are going to have to install the Internet Information Server (IIS).

Normally, the IIS is installed automatically with every server installation unless you have explicitly indicated that you do not want it installed. You can also install it later by opening the Add/Remove Programs control panel and clicking Add/Remove Windows Components. The IIS installation is one of the listed options.

When you are installing the IIS on a server, click the details box and only select those options that you are going to use. If you are not going to need the FTP service, don't install it. If you have already installed it, uninstall it in the same control panel. Generally, you will need the Internet Information Server Snap-in plus any servers you want to install. The snap-in is used to manage the server.

Do not install the FrontPage extensions, documentation, and sample applications on your working server. FrontPage extensions, documentation and sample applications are for web page development and should only be placed on a web development machine that is only accessible to the web developers. When new web pages are ready to be published onto the main server, they should be copied onto the server using a protected connection such as VPN or SFTP (Secure FTP, a part of SSH), or using a program such as ROBOCOPY, which is available in the resource kit. RoboCopy uses the LanManager connection to copy files and so should be run through an IPSec secured connection to the server. RoboCopy is useful for pushing over files because the files it pushes can be selected so it does not push over the sample or FrontPage files and only files that have changed are copied to the server.

\subsection{Post Install Security SetTings}

\subsubsection{Patching IIS}

After the IIS server is installed, you should connect to WindowsUpdate (http://windowsupdate.microsoft.com), or to wherever you maintain your security patches, and install all required security patches.

\subsubsection{Set Appropriate Web Directory Permissions}

Set permissions for the various files within your web application to give yourself the most protection. It is easiest to partition the web space into folders that separate the executable content such as programs and scripts from the static content such as web pages and images. In this way, you can set the permissions at the folder level and the files in the folder will inherit the permissions.

Remove the Everyone group from all the web directories. Create a WebUser group and put any users who are going to have access to this website in that group. If this is going to be an anonymous web server (no login required), put the IUSR_machinename user into 
the WebUser group. Give the WebUser read only access to the directories containing static files and execute access for directories containing scripts and executables.

In addition, give the Administrator and System users full control to these directories. On your development machine, create a WebDevelopers group to contain the usernames of the people who are going to be allowed to create and modify web pages and give that group Full Access to all of the web pages.

Warning: On development systems where the Front Page server extensions are installed, do not change the permissions of the directories that start with _vti (for example, vti_bin) as it is the file permissions on these directories that controls who can remotely administer the web. If you give the IUSR_machinename user execute access to the auth.dll file in the vti_binlauth directory, anyone who can connect to your webserver will be able to change your web pages without being required to login.

Warning: Beware when reinstalling web services such as the Front Page extensions. The FrontPage installer assumes you are going to be developing an anonymous website and gives everyone read access to the whole site when it is installed. Be sure to go back and check file permissions after reinstalling any web related software.

Because this happens so often, you should create a Security Configuration and Analysis template that sets the appropriate access control on all the directories in your website. After reinstalling web software you can check for any changes using the Analyze now action and reset the access control using the Configure now action.

\subsubsection{Set Access Controls on IIS Log Files}

The IIS-generated log files are in the following directory, 8s systemrooto \system $32 \backslash$ LogFiles

Set the access permissions to that directory to the following, to prevent intruders from deleting the web files to hide their activities.

- Administrators (Full Control)

- System (Full Control)

- WebUser (Read Write Create)

\subsubsection{Turn on Web Logging}

Turn on web logging using the Internet Information Services MMC console. Select the site you are setting and click properties. In the dialog box that appears, click the Web Site 
tab and check Enable Logging. Click the Active Log Format drop down list and select W3C Extended Log File Format. Select the following properties to log.

- Client IP Address

- User Name

- Method

- URI Stem

- HTTP Status

- Win32 Error

- User Agent

- Server IP Address

- Server Port

\subsubsection{Turn on Secure Sockets Layer Encryption}

If this is not going to be an anonymous website, that is, you are going to require your users to login, you need to protect the communications. If you are using basic authentication, which is what you must use if your users are remotely accessing your web server and you are using Windows file protections to control access, you should protect the whole session. This is because the username and password are sent to the server with every web request after the initial login and they are only protected with a simple hash that is easily broken.

If your web application is doing the login and then controlling the later connections with a cookie, you need only encrypt the login pages.

To turn on SSL encryption, you first need a server certificate which you can buy from vendors like VeriSign or create yourself using a certificate generator. Note that to use a self generated server certificate, all your users must set their browsers to trust your root certificate. The certificate request is generated and the resulting key is installed using the Key Manager console.

After the certificate is installed, SSL is activated using the Internet Information Server console. Select the file or directory you want to protect and choose properties. Choose the Directory Security tab and click the Edit button under Secure Communications. Check Require Secure Channel when accessing this resource to turn on SSL. Click Encryption Settings and check Require 128 bit Encryption to require high security instead of 40 bit encryption.

Note: Using SSL is supposed to significantly slow down web communications, but our experience indicates that it is not noticeable.

\subsubsection{Remove All Sample Applications}

Sample applications should only be allowed on the web development server which can only be accessed by the web developers. Remove all sample applications from the production servers. These samples need to be deleted off the hard drive and the Virtual directory removed from the website. 
Some common samples installed automatically by web server installers are as follows:

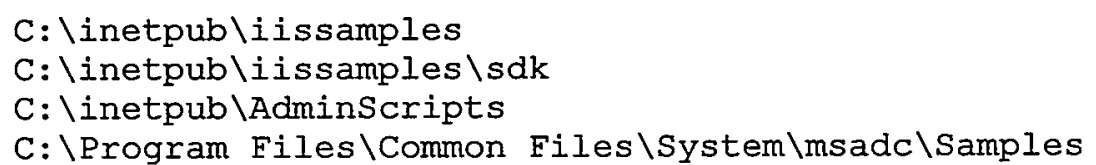

\subsubsection{Remove the IISADMPWD Virtual Directory}

This directory allows you to change Windows NT passwords using the web.

Open the Internet Information Server console and find IISADMPWD in the list of virtual directories. Click on that one and click Delete. You can also remove the files which are in the following directory.

8systemRooto $\backslash$ System32 $\backslash$ inetsrv\iisadmpwd

\subsubsection{Remove the IISADM Virtual Directory}

This directory allows you to configure the web server using web pages.

Open the Internet Information Server console and find IISADM in the list of virtual directories. Click on that one and click Delete. You can also remove the files which are in the following directory.

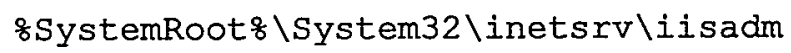

\subsubsection{Remove Unused Script Mappings}

The IIS is configured to support several common file extensions. The server operates by specifying which .DLL file to use to process each file type. Any extensions that you are not using should be removed.

Open Internet Services Manager console, click on the Default Web server and choose properties. Click Home Directory and Configuration to open the App Mappings window. Select any file extensions that you are not using and click Delete. Most modern servers use Active Server Pages and web pages with server-side includes. All the others can probably be removed. The index server extensions are tied to several vulnerabilities and should be removed.

\begin{tabular}{|c|c|}
\hline lixtension & I)escription \\
\hline .asp, .asa & Active Server Pages \\
\hline .htr & Web-based Password Reset \\
\hline .ida, .idq, .htw & Index Server \\
\hline idc & $\begin{array}{l}\text { Internet Database Connector } \\
\text { (obsolete use ADO from Active Server }\end{array}$ \\
\hline
\end{tabular}




\begin{tabular}{|l|l|}
\hline & Pages) \\
\hline. shtm, stm,. shtml & Web pages containing server-side includes \\
\hline
\end{tabular}

\subsubsection{Disable RDS Support}

The RDS Data Factory is probably the most attacked facility in the IIS server. It is used to allow special Active-X controls on web pages to directly connect to a database through a web server without having to reload the whole page. If it is not being used, it should be removed. If it is being used, you should make sure it is well patched and up to date.

To disable it, open the default website and find the MSADC virtual directory. Click on it and click delete. You can also delete the files themselves which are in the following directory.

\&SystemDisko \Program Files \Common Files\system \msadc

\section{Maintaining Security Configurations}

Now that you have your system configured and secure, how do you keep it that way. As fast as we apply security patches, intruders find other ways into out systems. The following tools are available to help keep your systems configured and secure.

- WindowsUpdate

- HFNETCHK

- Critical Update Notification

- Microsoft Security Bulletins

\subsection{USING Windows UpDaTE}

WindowsUpdate is actually a website that you connect your system to.

http://windowsupdate.microsoft.com

In the web page that opens, click on Product Updates to begin the process. A java applet is downloaded to your system along with a database of required updates. The Java applet will examine your system and give you a list of all the updates installed on your system and any new updates that you might need. The updates are divided into six classes.

- Critical Updates

- Picks of the Month

- Advanced Security Updates

- Recommended Updates

- Additional Windows Features

- Device Drivers 
Generally, you should always install any critical updates that are listed. Consider the other updates only if your application needs them. To install any updates, simply check them, click install, and follow the directions.

\subsection{USING HFNETCHK}

HFNETCHK is another tool for examining a system and listing any needed updates and security patches. It is useful to a system manager because it can examine all the machines in a domain from a single location.

Download HFNETCHK from the following location.

http://www.microsoft.com/technet/security/tools/hfnetchk.asp

When you run the tool, it downloads the latest database of required patches and hot fixes from Microsoft. If you execute it without any options, it scans the system you are running it on. If you use the $-r$ switch followed by an IP address range it will scan all the computers in that range. Note that the computers in the range must be in your domain and you must be logged in as the domain admin to access the systems. The result is a list of Microsoft technet article numbers and security bulletin numbers that you can then access to get more information about the patch. Note that patches listed with a warning are those that it does not know how to detect. You will have to determine by other means (such as computer logs or notes) if the patch is in place.

Appendix A shows the results of a run of the HFNETCHK tool.

\subsection{USING CRITICAL UPDATE NOTIFICATION}

Critical Update Notification is a tool you install in Windows 2000 that watches the Microsoft security website for new critical updates. If a new critical update is available, the tool displays a dialog box giving you the option to go to the windowsupdate website to install the critical update.

The critical update notification tool is included with Windows 2000 and is installed by default. The tool is also available from the windowsupdate website

http://windowsupdate.microsoft.com

\subsection{USING MICROSOFT SECURITY BULLETINS}

Microsoft security bulletins are available on the Microsoft website at the following address.

http://www.microsoft.com/technet/security/current.asp

You can also subscribe to the bulletins and have them delivered by e-mail at that same site. 


\subsection{Microsoft Personal Security AdVisor}

http://www.microsoft.com/technet/security/tools/mpsa.asp

\subsection{Microsoft Security Checkists}

http://www.microsoft.com/technet/security/tools/tools.asp

\section{REFERENCES}

The following reference materials contain a considerable amount of information about the setup and management of Windows 2000. System managers

Microsoft, Windows 2000 Professional Resource Kit, Microsoft Press, (2000)

Microsoft, Windows 2000 Server Resource Kit, Microsoft Press, (2000)

Microsoft Windows Security Website

http://www.microsoft.com/security

NSA, NSA Windows 2000 Configuration Guides, National Security Agency, O http://nsa2. www. conxion. com/win $2 \mathrm{k} /$ index.html

NIST System Administration Guidance for Securing Microsoft Windows 2000 Professional System, Special Publication 800-43, National Institute of Standards and Technology, (2002)

http://csrc.nist.gov/itsec/guidance_w2Kpro.html

CIAC Bulletin J-043g: Creating Login Banners

http://www.ciac.org/ciac/bulletins/j-043.shtml 


\section{APPENDIX A - UsING HFNETCHK UPdATE MANAGER}

A sample run of the HFNETCHK tool.

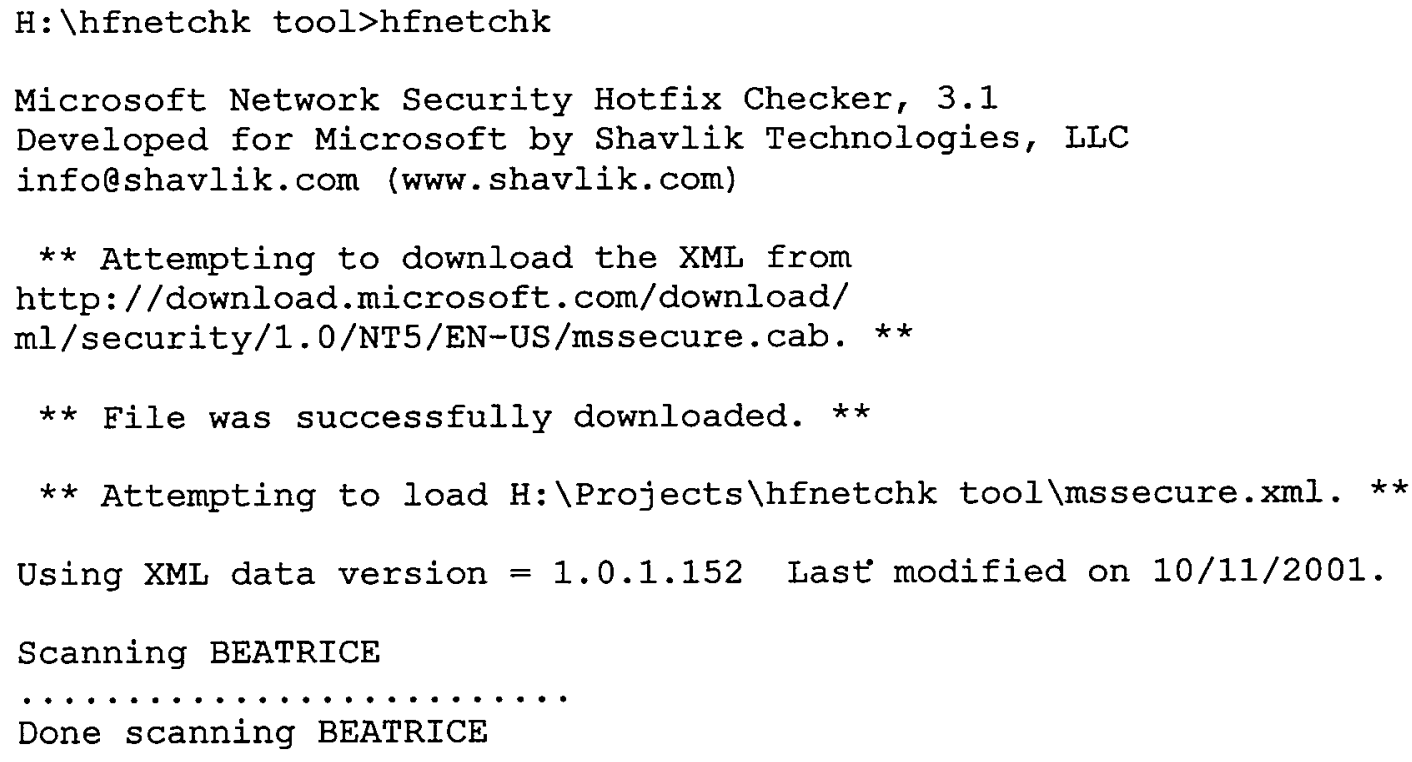

WINDOWS 2000 SP2

WARNING MS01-022

Patch NOT Found MS01-041
Q296441

Q298012 


\section{APPENDIX B - - USING QCHAIN}

Windows installers for security patches often cannot replace files that are in use. To replace these files, they schedule a startup job that replaces the file at boot time and require a reboot when the installer completes. This is why Windows installers are always requiring reboots. If you try to install multiple patches, the startup job for one patch may overwrite the startup job for a previous patch. The Qchain program is available on the Microsoft website to chain several patches together and apply them without having to reboot between each patch.

http://support.microsoft.com/support/kb/articles/Q296/8/61.asp 
, 


\section{APPENDIX C - DOE LOGIN BANNER}

Login banners are required on all U.S. Department of Energy computers. CIAC Bulletin J-043g: Creating Login Banners contains the current banner and instructions for installing it on different operating systems. On Windows systems, the banner and its title are installed in the following registry key.

HKLM \SOFTWARE \Microsoft \WindowS NT\CurrentVersion \Winlogon

Name: LegalNoticeCaption

Type: REG_Sz

Value: NOTICE TO USERS

Name: LegalNoticeText

Type: REG_SZ

Value: See notice below.

The same values can be inserted in the Policies registry key, whose values override those in the winlogon key.

HKLM \SOFTWARE \Microsoft $\backslash W$ indows $\backslash$ CurrentVersion $\backslash$ Policies $\backslash s y s t e m$

Following is the text of the banner.

\section{NOTICE TO USERS}

This is a Federal computer system and is the property of the United States Government. It is for authorized use only. Users (authorized or unauthorized) have no explicit or implicit expectation of privacy.

Any or all uses of this system and all files on this system may be intercepted, monitored, recorded, copied, audited, inspected, and disclosed to authorized site, Department of Energy, and law enforcement personnel, as well as authorized officials of other agencies, both domestic and foreign. By using this system, the user consents to such interception, monitoring, recording, copying, auditing, inspection, and disclosure at the discretion of authorized site or Department of Energy personnel.

Unauthorized or improper use of this system may result in administrative disciplinary action and civil and criminal penalties. By continuing to use this system you indicate your awareness of and consent to these terms and conditions of use. LOG OFF IMMEDIATELY if you do not agree to the conditions stated in this warning. 
. 


\section{APPENdIX D - InCluded SECURITy Configuration MANAger TeMPlates}

The Windows 2000 operating system contains several built-in templates that work with the Security Configuration and Analysis console. These templates define different levels of security for a Windows system.

\section{DEFAULT INSTALlation TEMPLATES}

These templates define the default configuration of a newly installed Windows 2000 system.

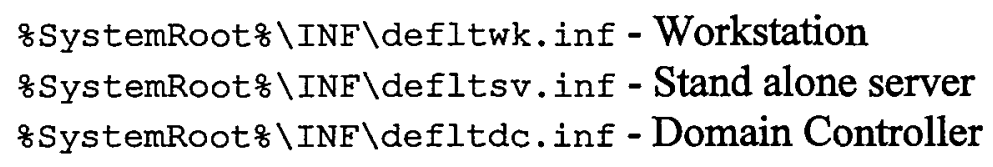

\section{SECURITY TEMPLATES}

The security templates come in three different levels, basic, secure, high-security, dedicated domain controller, and compatibility. These templates are all in the default location for the Security Configuration and Analysis console.

8systemRooto $\backslash$ security $\backslash$ templates

\section{Basic Security Templates}

The basic security templates are primarily for reversing the application of the higher security templates. They set all the security settings to the Windows 2000 default values except for user rights.

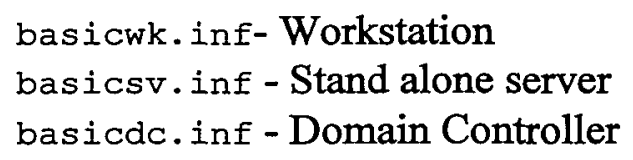

\section{Secure Templates}

The Secure templates implement the recommended security settings for everything but files, folders, and registry keys. The default configuration for files, folders, and registry keys is considered to be secure.

$$
\begin{aligned}
& \text { securews . inf- Workstation or Server } \\
& \text { securedc. inf - Domain Controller }
\end{aligned}
$$

\section{High Security Templates}

The High-security templates add settings for secure Windows 2000 network communications to the Secure templates. These settings are only usable in a pure Windows 2000 network as older versions of Windows will not be able to communicate with this system.

$$
\text { hisecws. inf- Workstation or Server }
$$




\section{Compatible Template}

The compatible template is primarily for upgrades of Windows 2000 from Windows NT. Widows 2000 Users have stricter security settings than Users in Windows NT so Windows 2000 Users may not be able to run some legacy applications that have not been certified to run under Windows 2000. The Windows 2000 Power Users are comparable to the Windows NT Users. If you do not want your normal users to be in the Power Users group in order to run legacy applications, you can apply the compatibility template which decreases the security of the Users group to the point where they should be able to run legacy applications.

compatws .inf- Compatible Workstation

\section{Setup Security Template}

The Setup Security template contains the default configuration settings placed on this system when it was installed. This gives you a chance to get back to the installation configuration. Some application installers change directory permissions and user rights and this template may reverse those settings. Be careful with the application of this template as it may make some applications unexecutable.

setup security.inf- Setup Security Settings

\section{Dedicated domain Controller Template}

Use the Dedicated Domain Controller template on domain controllers that do not run other server based applications. The security settings on Domain Controllers are designed to allow the Administrator run server based applications on the domain controller. This causes the security of the local Users group to be less than ideal. Apply this template on Domain Controllers that do not run other server based applications.

dedicadc.inf - Dedicated Domain Controller 


\section{APPENDIX E - CIAC SECURITY CONFIGURATION AND ANALYSIS TEMPlate}

This appendix describes all the settings that you can make in the Security Configuration and Analysis MMC console. The title of each table refers to the location in the Security Configuration and Analysis console where the setting exists. We also include the suggested CIAC setting for each of these items. Items marked "Not Defined" are not set in the CIAC templates. $\mathrm{DC}=$ Domain Controller, $\mathrm{AD}=$ Active Directory, Empty means the option is defined but contains no values.

\section{Account Policies/Password Policy}

\begin{tabular}{|c|c|c|c|}
\hline Policy & Description & $\begin{array}{l}\text { Workstation } \\
\text { Serting }\end{array}$ & I) ( Setting \\
\hline $\begin{array}{l}\text { Enforce password } \\
\text { history }\end{array}$ & $\begin{array}{l}\text { The number of passwords the } \\
\text { system remembers to prevent a user } \\
\text { from reusing an old password too } \\
\text { soon. }\end{array}$ & 10 & 10 \\
\hline $\begin{array}{l}\text { Maximum } \\
\text { password age }\end{array}$ & $\begin{array}{l}\text { The maximum age of a password } \\
\text { after which it must be changed. } \\
\text { Reduce this to } 90 \text { days if the } \\
\text { passwords are sent in the clear over } \\
\text { the network, such as with the old } \\
\text { LanManager protocol. }\end{array}$ & 180 days & 180 days \\
\hline $\begin{array}{l}\text { Minimum } \\
\text { password age }\end{array}$ & $\begin{array}{l}\text { The minimum amount of time a user } \\
\text { must wait before changing a } \\
\text { password again. This is to prevent a } \\
\text { user from defeating the password } \\
\text { history by changing the password } \\
\text { multiple times. }\end{array}$ & 0 days & 0 days \\
\hline $\begin{array}{l}\text { Minimum } \\
\text { password length }\end{array}$ & The minimum length for a password. & 8 characters & 8 characters \\
\hline $\begin{array}{l}\text { Passwords must } \\
\text { meet complexity } \\
\text { requirements }\end{array}$ & $\begin{array}{l}\text { Require a password to not include } \\
\text { the account name and to contain } \\
\text { characters from at least three of the } \\
\text { following character sets: lower case } \\
\text { letters, upper case letters, numbers, } \\
\text { and symbols. }\end{array}$ & Enabled & Enabled \\
\hline $\begin{array}{l}\text { Store password } \\
\text { using reversible } \\
\text { encryption for all } \\
\text { users in the } \\
\text { domain }\end{array}$ & $\begin{array}{l}\text { Stores passwords in the clear for } \\
\text { applications that need them for } \\
\text { authentication. }\end{array}$ & Disabled & Disabled \\
\hline
\end{tabular}


Account Policies/Account Lockout Policy

\begin{tabular}{|l|l|l|l|}
\hline Policy & Description & Setting \\
\hline $\begin{array}{l}\text { Account lockout } \\
\text { duration }\end{array}$ & $\begin{array}{l}\text { The length of time an account is } \\
\text { locked out because of login failures. } \\
\text { A locked out account will be } \\
\text { reenabled after this time. }\end{array}$ & 30 minutes & 30 minutes \\
\hline $\begin{array}{l}\text { Account lockout } \\
\text { threshold }\end{array}$ & $\begin{array}{l}\text { The number of login failures that } \\
\text { triggers a lockout. This is to prevent } \\
\text { someone from trying to b This does } \\
\text { not apply to the Administrator } \\
\text { account, which cannot be locked } \\
\text { out. Network logins to the } \\
\text { administrator account can be set to } \\
\text { lock out. See key?? }\end{array}$ & $\begin{array}{l}5 \text { invalid logon } \\
\text { attempts }\end{array}$ & $\begin{array}{l}5 \text { invalid logon } \\
\text { attempts }\end{array}$ \\
\hline $\begin{array}{l}\text { Reset account } \\
\text { lockout counter } \\
\text { after }\end{array}$ & $\begin{array}{l}\text { The count of login failures is reset to } \\
\text { zero after this amount of time. }\end{array}$ & 30 minutes & 30 Minutes \\
\hline
\end{tabular}

\section{ACCOUnt Policies/Kerberos Policy}

These only apply if you are using Kerberos authentication.

\begin{tabular}{|l|l|l|l|}
\hline Polic! & Iescription & Enabled \\
\hline $\begin{array}{l}\text { Enforce user logon } \\
\text { restrictions }\end{array}$ & $\begin{array}{l}\text { Requires the KDC to validate every } \\
\text { request for a session ticket. }\end{array}$ & Disabled \\
\hline $\begin{array}{l}\text { Maximum lifetime } \\
\text { for service ticket }\end{array}$ & $\begin{array}{l}\text { The maximum time that a session } \\
\text { ticket may be used to access a } \\
\text { service. Must be greater than 10 } \\
\text { minutes and less than the Maximum } \\
\text { lifetime for a user ticket. }\end{array}$ & 600 minutes & 600 minutes \\
\hline $\begin{array}{l}\text { Maximum lifetime } \\
\text { for user ticket }\end{array}$ & $\begin{array}{l}\text { The Maximum lifetime for a user's } \\
\text { ticket granting ticket may be used. }\end{array}$ & 10 hours & 10 hours \\
\hline $\begin{array}{l}\text { Maximum lifetime } \\
\text { for user ticket } \\
\text { renewal }\end{array}$ & $\begin{array}{l}\text { The period over which a user's } \\
\text { ticket granting ticket may be } \\
\text { renewed. }\end{array}$ & 7 days & 7 days \\
\hline $\begin{array}{l}\text { Maximum } \\
\text { tolerance for } \\
\text { computer clock } \\
\text { synchronization }\end{array}$ & $\begin{array}{l}\text { The maximum difference between a } \\
\text { server's clock and a user's clock that } \\
\text { will be tolerated. This is to prevent } \\
\text { "replay attacks" where an attempt is } \\
\text { made to reuse an old ticket by } \\
\text { setting back the clock on a } \\
\text { workstation. }\end{array}$ & 5 minutes & 5 minutes \\
\hline
\end{tabular}


Local Policies/Audit Policy

\begin{tabular}{|c|c|c|c|}
\hline Policy & Description & $\begin{array}{l}\text { Workstation } \\
\text { Setting }\end{array}$ & d) Setting \\
\hline $\begin{array}{l}\text { Audit account } \\
\text { logon events }\end{array}$ & $\begin{array}{l}\text { Audit success or failure of logons to } \\
\text { other systems where this system was } \\
\text { used to authenticate the user. This } \\
\text { only has meaning on a domain } \\
\text { controller. }\end{array}$ & No Auditing & $\begin{array}{l}\text { Success, Failure } \\
\text { on a DC. }\end{array}$ \\
\hline $\begin{array}{l}\text { Audit account } \\
\text { management }\end{array}$ & $\begin{array}{l}\text { Audit the success or failure of } \\
\text { account management actions, such } \\
\text { as creating, changing or deleting a } \\
\text { new account, changing a password, } \\
\text { etc. }\end{array}$ & Success, Failure & Success, Failure \\
\hline $\begin{array}{l}\text { Audit directory } \\
\text { service access }\end{array}$ & $\begin{array}{l}\text { Audits the success or failure of } \\
\text { access to an Active Directory object. } \\
\text { This only has meaning on an Active } \\
\text { Directory domain controller. }\end{array}$ & No Auditing & $\begin{array}{l}\text { Success, Failure } \\
\text { if this is an } \mathrm{AD} \\
\text { DC. }\end{array}$ \\
\hline Audit logon events & $\begin{array}{l}\text { Audit success or failure of logons to } \\
\text { this system. Includes both console } \\
\text { and network logons. }\end{array}$ & Success, Failure & Success, Failure \\
\hline Audit object access & $\begin{array}{l}\text { Audit success or failure of accesses } \\
\text { to system objects such as files, } \\
\text { folders, printers, etc. as long as the } \\
\text { object has its own access control } \\
\text { setting. }\end{array}$ & Success, Failure & Success, Failure \\
\hline $\begin{array}{l}\text { Audit policy } \\
\text { change }\end{array}$ & $\begin{array}{l}\text { Audit success or failure of changes } \\
\text { to the user rights, audit, or trust } \\
\text { policies on this machine. }\end{array}$ & Success, Failure & Success, Failure \\
\hline Audit privilege use & $\begin{array}{l}\text { Audit the success or failure of a user } \\
\text { exercising a user right except } \\
\text { Backup and Restore. See also "Audit } \\
\text { use of Backup and Restore } \\
\text { privilege." }\end{array}$ & Success, Failure & Success, Failure \\
\hline $\begin{array}{l}\text { Audit process } \\
\text { tracking }\end{array}$ & $\begin{array}{l}\text { Audit process startup, shutdown, } \\
\text { handle duplication, and indirect } \\
\text { object access. This is primarily a } \\
\text { debugging tool. }\end{array}$ & No Auditing & No Auditing \\
\hline $\begin{array}{l}\text { Audit system } \\
\text { events }\end{array}$ & $\begin{array}{l}\text { Audit system startup, shutdown, and } \\
\text { changes to the auditing system. }\end{array}$ & Success, Failure & Success, Failure \\
\hline
\end{tabular}




\begin{tabular}{|c|c|c|c|}
\hline Policy & Description & $\begin{array}{l}\text { Workstation } \\
\text { Setting }\end{array}$ & I) Setting \\
\hline $\begin{array}{l}\text { Access this } \\
\text { computer from the } \\
\text { network }\end{array}$ & $\begin{array}{l}\text { Users who may make network } \\
\text { logins to this computer. If this is an } \\
\text { IIS server, the IIS guest account } \\
\text { (IUSR machinename) must be here } \\
\text { even if you are going to force an } \\
\text { authenticated login. }\end{array}$ & $\begin{array}{l}\text { Backup } \\
\text { Operators, } \\
\text { Power Users, } \\
\text { Users, } \\
\text { Administrators }\end{array}$ & $\begin{array}{l}\text { Backup } \\
\text { Operators, } \\
\text { Power Users, } \\
\text { Users, } \\
\text { Administrators }\end{array}$ \\
\hline $\begin{array}{l}\text { Act as part of the } \\
\text { operating system }\end{array}$ & $\begin{array}{l}\text { Allows a process to authenticate as } \\
\text { any user, giving it access to all of a } \\
\text { users resources. Normally only } \\
\text { needed by low level resources. }\end{array}$ & Empty & Empty \\
\hline $\begin{array}{l}\text { Add workstations } \\
\text { to domain }\end{array}$ & $\begin{array}{l}\text { Users who may create computer } \\
\text { accounts in a domain. Only valid on } \\
\text { a domain controller. }\end{array}$ & Empty & $\begin{array}{l}\text { Authenticated } \\
\text { Users }\end{array}$ \\
\hline $\begin{array}{l}\text { Back up files and } \\
\text { directories }\end{array}$ & $\begin{array}{l}\text { Users who may circumvent file } \\
\text { protections to backup a system. } \\
\text { Gives read access to the whole } \\
\text { system. See also Restore Files and } \\
\text { Directories. }\end{array}$ & $\begin{array}{l}\text { Backup } \\
\text { Operators, } \\
\text { Administrators }\end{array}$ & $\begin{array}{l}\text { Backup } \\
\text { Operators, } \\
\text { Administrators }\end{array}$ \\
\hline $\begin{array}{l}\text { Bypass traverse } \\
\text { checking }\end{array}$ & $\begin{array}{l}\text { Users who may bypass traverse file } \\
\text { access checking. Allows a user to } \\
\text { pass over a directory for which he } \\
\text { does not have access to read files in } \\
\text { a subdirectory for which he does } \\
\text { have access. }\end{array}$ & $\begin{array}{l}\text { Backup } \\
\text { Operators, } \\
\text { Power Users, } \\
\text { Users, } \\
\text { Administrators }\end{array}$ & $\begin{array}{l}\text { Administrators, } \\
\text { Authenticated } \\
\text { Users }\end{array}$ \\
\hline $\begin{array}{l}\text { Change the system } \\
\text { time }\end{array}$ & $\begin{array}{l}\text { Users who may change the system } \\
\text { clock. }\end{array}$ & $\begin{array}{l}\text { Administrators, } \\
\text { Power Users }\end{array}$ & $\begin{array}{l}\text { Administrators, } \\
\text { Server } \\
\text { Operators } \\
\end{array}$ \\
\hline Create a pagefile & $\begin{array}{l}\text { Users with the ability to create or } \\
\text { change a pagefile. }\end{array}$ & Administrators & Administrators \\
\hline $\begin{array}{l}\text { Create a token } \\
\text { object }\end{array}$ & $\begin{array}{l}\text { Accounts that can be used to create } \\
\text { access tokens. This should only be } \\
\text { used by low level system processes. }\end{array}$ & Empty & Empty \\
\hline $\begin{array}{l}\text { Create permanent } \\
\text { shared objects }\end{array}$ & $\begin{array}{l}\text { Accounts that can create a directory } \\
\text { object in the Windows } 2000 \text { object } \\
\text { manager. This should only be used } \\
\text { by low level system objects. }\end{array}$ & Empty & Empty \\
\hline Debug programs & $\begin{array}{l}\text { Users who can attach a debugger to } \\
\text { any process. Software developers } \\
\text { may need this. }\end{array}$ & Administrators & Administrators \\
\hline $\begin{array}{l}\text { Deny access to this } \\
\text { computer from the } \\
\text { network }\end{array}$ & $\begin{array}{l}\text { Users who may not access this } \\
\text { computer from the network. } \\
\text { Supercedes "Access this computer }\end{array}$ & Empty & Empty \\
\hline
\end{tabular}




\begin{tabular}{|c|c|c|c|}
\hline & $\begin{array}{l}\text { from the network." if a user appears } \\
\text { in both. }\end{array}$ & & \\
\hline $\begin{array}{l}\text { Deny logon as a } \\
\text { batch job }\end{array}$ & $\begin{array}{l}\text { Users who may not login as a batch } \\
\text { job. Supercedes "Log on as a batch } \\
\text { job." if a user appears in both. }\end{array}$ & Empty & Empty \\
\hline $\begin{array}{l}\text { Deny logon as a } \\
\text { service }\end{array}$ & $\begin{array}{l}\text { Users who may not register a } \\
\text { process as a service. Supercedes } \\
\text { "Log on as a service." if a user } \\
\text { appears in both. }\end{array}$ & Empty & Empty \\
\hline Deny logon locally & $\begin{array}{l}\text { Users who may not login locally. } \\
\text { Supercedes "Login locally." if a user } \\
\text { appears in both. }\end{array}$ & Empty & Empty \\
\hline $\begin{array}{l}\text { Enable computer } \\
\text { and user accounts } \\
\text { to be trusted for } \\
\text { delegation }\end{array}$ & $\begin{array}{l}\text { Users who may use another user's } \\
\text { delegated credentials. }\end{array}$ & Empty & Administrators \\
\hline $\begin{array}{l}\text { Force shutdown } \\
\text { from a remote } \\
\text { system }\end{array}$ & $\begin{array}{l}\text { Users who may remotely shutdown } \\
\text { a computer. }\end{array}$ & Administrators & $\begin{array}{l}\text { Administrators, } \\
\text { Server } \\
\text { Operators }\end{array}$ \\
\hline $\begin{array}{l}\text { Generate security } \\
\text { audits }\end{array}$ & $\begin{array}{l}\text { Users who may generate entries in } \\
\text { the system security log. This right is } \\
\text { normally only used by low level } \\
\text { system processes. }\end{array}$ & None & None \\
\hline Increase quotas & $\begin{array}{l}\text { Users who may increase the } \\
\text { processor quota of a process }\end{array}$ & Administrators & Administrators \\
\hline $\begin{array}{l}\text { Increase } \\
\text { scheduling priority }\end{array}$ & $\begin{array}{l}\text { Users who may change the } \\
\text { execution priority of a process. }\end{array}$ & Administrators & Administrators \\
\hline $\begin{array}{l}\text { Load and unload } \\
\text { device drivers }\end{array}$ & $\begin{array}{l}\text { Users who may dynamically load } \\
\text { and unload device drivers. }\end{array}$ & Administrators & Administrators \\
\hline $\begin{array}{l}\text { Lock pages in } \\
\text { memory }\end{array}$ & Obsolete, not used. & None & None \\
\hline $\begin{array}{l}\text { Log on as a batch } \\
\text { job }\end{array}$ & $\begin{array}{l}\text { Users who may login as a batch job. } \\
\text { Used by processes like the task } \\
\text { scheduler to run a batch job as a } \\
\text { user. See also "Deny log on as a } \\
\text { batch job." }\end{array}$ & Not defined & Not defined \\
\hline Log on as a service & $\begin{array}{l}\text { Users who may register a process as } \\
\text { a service. See also "Deny log on as a } \\
\text { service." }\end{array}$ & Not defined & Not defined \\
\hline Log on locally & $\begin{array}{l}\text { Users who can log on locally. This } \\
\text { includes logons at the console and } \\
\text { the guest accounts (such as } \\
\text { IUSR machinename) who must } \\
\text { authenticate as a real user to get } \\
\text { expanded access. }\end{array}$ & $\begin{array}{l}\text { Backup } \\
\text { Operators, } \\
\text { Power Users, } \\
\text { Users, } \\
\text { Administrators }\end{array}$ & $\begin{array}{l}\text { Backup } \\
\text { Operators, } \\
\text { Account } \\
\text { Operators, Print } \\
\text { Operators, } \\
\text { Administrators } \\
\end{array}$ \\
\hline
\end{tabular}




\begin{tabular}{|c|c|c|c|}
\hline $\begin{array}{l}\text { Manage auditing } \\
\text { and security log }\end{array}$ & $\begin{array}{l}\text { Users who may specify auditing on } \\
\text { system objects such as files, } \\
\text { directories, and Active Directory } \\
\text { objects. Software developers may } \\
\text { need this. }\end{array}$ & Administrators & Administrators \\
\hline $\begin{array}{l}\text { Modify firmware } \\
\text { environment } \\
\text { values }\end{array}$ & $\begin{array}{l}\text { Users who may modify system wide } \\
\text { environment variables. }\end{array}$ & Administrators & Administrators \\
\hline $\begin{array}{l}\text { Profile single } \\
\text { process }\end{array}$ & $\begin{array}{l}\text { Users who may use process profiling } \\
\text { tools to measure the performance of } \\
\text { non system processes. Software } \\
\text { developers may need this. }\end{array}$ & $\begin{array}{l}\text { Administrators, } \\
\text { Power Users }\end{array}$ & Administrators \\
\hline $\begin{array}{l}\text { Profile system } \\
\text { performance }\end{array}$ & $\begin{array}{l}\text { Users who may use process profiling } \\
\text { tools to measure the performance of } \\
\text { system processes. }\end{array}$ & Administrators & Administrators \\
\hline $\begin{array}{l}\text { Remove computer } \\
\text { from docking } \\
\text { station }\end{array}$ & $\begin{array}{l}\text { Users who may undock a laptop } \\
\text { from a docking station. Domain } \\
\text { controllers should not be } \\
\text { undockable. }\end{array}$ & $\begin{array}{l}\text { Power Users, } \\
\text { Users, } \\
\text { Administrators }\end{array}$ & None \\
\hline $\begin{array}{l}\text { Replace a process } \\
\text { level token }\end{array}$ & $\begin{array}{l}\text { Users who can replace the access } \\
\text { token of a running process. This } \\
\text { right is normally only used by low } \\
\text { level system processes. }\end{array}$ & Empty & Empty \\
\hline $\begin{array}{l}\text { Restore files and } \\
\text { directories }\end{array}$ & $\begin{array}{l}\text { Users who can circumvent local file } \\
\text { and directory protections to restore } \\
\text { files from a backup. See also "Back } \\
\text { up files and directories." }\end{array}$ & $\begin{array}{l}\text { Backup } \\
\text { Operators, } \\
\text { Administrators }\end{array}$ & $\begin{array}{l}\text { Backup } \\
\text { Operators, } \\
\text { Server } \\
\text { Operators, } \\
\text { Administrators } \\
\end{array}$ \\
\hline $\begin{array}{l}\text { Shut down the } \\
\text { system }\end{array}$ & $\begin{array}{l}\text { Users who, while logged on locally, } \\
\text { can shut down the system. See also, } \\
\text { "Force shutdown from a remote } \\
\text { system." }\end{array}$ & $\begin{array}{l}\text { Backup } \\
\text { Operators, } \\
\text { Power Users, } \\
\text { Users, } \\
\text { Administrators }\end{array}$ & $\begin{array}{l}\text { Backup } \\
\text { Operators, } \\
\text { Account } \\
\text { Operators, } \\
\text { Server } \\
\text { Operators, Print } \\
\text { Operators, } \\
\text { Administrators } \\
\end{array}$ \\
\hline $\begin{array}{l}\text { Synchronize } \\
\text { directory service } \\
\text { data }\end{array}$ & Unused & Not defined & Not defined \\
\hline $\begin{array}{l}\text { Take ownership of } \\
\text { files or other } \\
\text { objects }\end{array}$ & $\begin{array}{l}\text { Users who can take ownership of } \\
\text { secured objects, such as files, } \\
\text { directories, processes, printers, etc. }\end{array}$ & Administrators & Administrators \\
\hline
\end{tabular}




\begin{tabular}{|c|c|c|c|}
\hline Policy & 1)escription & $\begin{array}{l}\text { Iorkstation } \\
\text { Sctting }\end{array}$ & I) C Setting \\
\hline $\begin{array}{l}\text { Additional } \\
\text { restrictions for } \\
\text { anonymous } \\
\text { connections }\end{array}$ & $\begin{array}{l}\text { Determines additional restrictions } \\
\text { that are placed on anonymous } \\
\text { connections. Options are: } \\
\text { - None. Rely on default } \\
\text { permissions. } \\
\text { - Do not allow enumeration of } \\
\text { SAM accounts and shares. } \\
\text { Replaces "Everyone" with } \\
\text { "Authenticated Users" in the } \\
\text { security permissions for } \\
\text { resources. } \\
\text { - No access without explicit } \\
\text { anonymous permissions. } \\
\text { Removes anonymous user from } \\
\text { "Everyone" and "Network." } \\
\text { Anonymous accounts must be } \\
\text { given explicit access to objects. } \\
\text { Everyone = Authenticated Users + } \\
\text { Guest + Anonymous }\end{array}$ & $\begin{array}{l}\text { Do not allow } \\
\text { enumeration of } \\
\text { SAM accounts } \\
\text { and shares }\end{array}$ & $\begin{array}{l}\text { Do not allow } \\
\text { enumeration of } \\
\text { SAM accounts } \\
\text { and shares }\end{array}$ \\
\hline $\begin{array}{l}\text { Allow server } \\
\text { operators to } \\
\text { schedule tasks } \\
\text { (domain } \\
\text { controllers only) }\end{array}$ & $\begin{array}{l}\text { Allows server operators to submit At } \\
\text { jobs for later execution. }\end{array}$ & Not defined & Not defined \\
\hline $\begin{array}{l}\text { Allow system to be } \\
\text { shut down without } \\
\text { having to log on }\end{array}$ & $\begin{array}{l}\text { Enables the Shut Down command } \\
\text { on the login window. On most } \\
\text { systems, users who can access the } \\
\text { login screen also have access to the } \\
\text { plug so it is better to allow them to } \\
\text { do a controlled shutdown than to } \\
\text { simply pull the plug. }\end{array}$ & Enabled & Enabled \\
\hline $\begin{array}{l}\text { Allowed to eject } \\
\text { removable NTFS } \\
\text { media }\end{array}$ & $\begin{array}{l}\text { Users who may eject removable } \\
\text { NTFS media. }\end{array}$ & $\begin{array}{l}\text { Administrators } \\
\text { and Interactive } \\
\text { User }\end{array}$ & Administrators \\
\hline $\begin{array}{l}\text { Amount of idle } \\
\text { time required } \\
\text { before } \\
\text { disconnecting } \\
\text { session }\end{array}$ & $\begin{array}{l}\text { Amount of idle time before a SMB } \\
\text { connection (Windows networking) } \\
\text { connection is automatically } \\
\text { disconnected. }\end{array}$ & 15 minutes & 15 minutes \\
\hline $\begin{array}{l}\text { Audit the access of } \\
\text { global system } \\
\text { objects }\end{array}$ & $\begin{array}{l}\text { Adds system access control lists to } \\
\text { system objects such as events, } \\
\text { semaphores, and drivers so access to }\end{array}$ & Disabled & Disabled \\
\hline
\end{tabular}




\begin{tabular}{|c|c|c|c|}
\hline & these objects can be audited. & & \\
\hline $\begin{array}{l}\text { Audit use of } \\
\text { Backup and } \\
\text { Restore privilege }\end{array}$ & $\begin{array}{l}\text { Adds Backup and Restore privilege } \\
\text { use to "Audit Privilege Use". } \\
\text { Enables "Audit Privilege Use." }\end{array}$ & Disabled & Disabled \\
\hline $\begin{array}{l}\text { Automatically } \log \\
\text { off users when } \\
\text { logon time expires }\end{array}$ & $\begin{array}{l}\text { Domain user accounts with explicit } \\
\text { login hours are logged off if they are } \\
\text { outside those hours. If this is } \\
\text { disabled, a login that is made during } \\
\text { a users normal hours is allowed to } \\
\text { continue outside of those hours. }\end{array}$ & Enabled & Enabled \\
\hline $\begin{array}{l}\text { Automatically log } \\
\text { off users when } \\
\text { logon time expires } \\
\text { (local) }\end{array}$ & $\begin{array}{l}\text { Local user accounts with explicit } \\
\text { login hours are logged off if they are } \\
\text { outside those hours. If this is } \\
\text { disabled, a login that is made during } \\
\text { a users normal hours is allowed to } \\
\text { continue outside of those hours. }\end{array}$ & Enabled & Enabled \\
\hline $\begin{array}{l}\text { Clear virtual } \\
\text { memory pagefile } \\
\text { when system shuts } \\
\text { down }\end{array}$ & $\begin{array}{l}\text { Clear the systems pagefile (swap) } \\
\text { when the system shuts down to } \\
\text { insure that there is no sensitive data } \\
\text { accessible on the disk. }\end{array}$ & Enabled & Enabled \\
\hline $\begin{array}{l}\text { Digitally sign } \\
\text { client } \\
\text { communication } \\
\text { (always) }\end{array}$ & $\begin{array}{l}\text { Always digitally sign SMB } \\
\text { (Windows Networking) client (you } \\
\text { are the client connecting to a server) } \\
\text { communications. Prevents man-in- } \\
\text { the-middle attacks. Both ends of the } \\
\text { communication must support the } \\
\text { signing. }\end{array}$ & Disabled & Disabled \\
\hline $\begin{array}{l}\text { Digitally sign } \\
\text { client } \\
\text { communication } \\
\text { (when possible) }\end{array}$ & $\begin{array}{l}\text { Digitally sign SMB (Windows } \\
\text { Networking) communications when } \\
\text { possible. Prevents man-in-the- } \\
\text { middle attacks. Both ends of the } \\
\text { communication must support the } \\
\text { signing. Enable this one to be able to } \\
\text { connect to servers that require } \\
\text { digital signatures. }\end{array}$ & Enabled & Enabled \\
\hline $\begin{array}{l}\text { Digitally sign } \\
\text { server } \\
\text { communication } \\
\text { (always) }\end{array}$ & $\begin{array}{l}\text { Always sign SMB (Windows } \\
\text { Networking) server (you are the } \\
\text { server) communications. Prevents } \\
\text { man-in-the-middle attacks. Both } \\
\text { ends of the communication must } \\
\text { support the signing. Clients who do } \\
\text { not have digital signing enabled will } \\
\text { not be able to connect. }\end{array}$ & Disabled & Disabled \\
\hline $\begin{array}{l}\text { Digitally sign } \\
\text { server } \\
\text { communication }\end{array}$ & $\begin{array}{l}\text { Sign SMB (Windows Networking) } \\
\text { server (from you to a server) } \\
\text { communications when possible. }\end{array}$ & Disabled & Enabled \\
\hline
\end{tabular}




\begin{tabular}{|c|c|c|c|}
\hline (when possible) & $\begin{array}{l}\text { Prevents man-in-the-middle attacks. } \\
\text { Both ends of the communication } \\
\text { must support the signing. }\end{array}$ & & \\
\hline $\begin{array}{l}\text { Disable } \\
\text { CTRL+ALT+DEL } \\
\text { requirement for } \\
\text { logon }\end{array}$ & $\begin{array}{l}\text { Disables the requirement to press } \\
\text { Ctrl-Alt-Del to get the login } \\
\text { window. Enabling this makes a } \\
\text { machine susceptible to password } \\
\text { capture programs. Beware of reverse } \\
\text { logic. }\end{array}$ & Disable & Disable \\
\hline $\begin{array}{l}\text { Do not display last } \\
\text { user name in logon } \\
\text { screen }\end{array}$ & $\begin{array}{l}\text { Does not display the last user to } \\
\text { login in the login dialog box. Should } \\
\text { be enabled on publicly accessible, } \\
\text { multi-user machines. }\end{array}$ & Disabled & Disabled \\
\hline $\begin{array}{l}\text { LAN Manager } \\
\text { Authentication } \\
\text { Level }\end{array}$ & $\begin{array}{l}\text { Set the authentication for network } \\
\text { authentication. Older systems } \\
\text { (Win95) require LanManager (LM) } \\
\text { logins. Windows NT } 4 \text { prior to SP4 } \\
\text { require LM or NTLM logins. This } \\
\text { should be set as high as possible } \\
\text { while still allowing all required } \\
\text { systems to communicate. The } \\
\text { allowed settings are: } \\
\text { - Send LM \& NTLM responses: } \\
\text { Clients use LM and NTLM } \\
\text { authentication, and never use } \\
\text { NTLMv2. DCs accept LM, } \\
\text { NTLM, and NTLMv2 } \\
\text { autheitication. } \\
\text { - Send LM \& NTLM - use } \\
\text { NTLMv2 session security if } \\
\text { negotiated: } \\
\text { Clients use LM and NTLM } \\
\text { authentication and use NTLMv2 } \\
\text { session security if the server } \\
\text { supports it. DCs accept LM, } \\
\text { NTLM, and NTLMv2 } \\
\text { authentication. } \\
\text { Send NTLM response only: } \\
\text { Clients use NTLM } \\
\text { authentication only and use } \\
\text { NTLMv2 session security if the } \\
\text { server supports it. DCs accept } \\
\text { LM, NTLM, and NTLMv2 } \\
\text { authentication. } \\
\text { - Send NTLMv2 response only: } \\
\text { Clients use NTLMv2 }\end{array}$ & $\begin{array}{l}\text { Send LM \& } \\
\text { NTLM } \\
\text { responses }\end{array}$ & $\begin{array}{l}\text { Send LM \& } \\
\text { NTLM } \\
\text { responses }\end{array}$ \\
\hline
\end{tabular}




\begin{tabular}{|c|c|c|c|}
\hline & $\begin{array}{l}\text { authentication only and use } \\
\text { NTLMv2 session security if the } \\
\text { server supports it. DCs accept } \\
\text { LM, NTLM, and NTLMv2 } \\
\text { authentication. } \\
\text { Send NTLMv2 response } \\
\text { only\refuse LM: } \\
\text { Clients use NTLMv2 } \\
\text { authentication only and use } \\
\text { NTLMv2 session security if the } \\
\text { server supports it. DCs refuse } \\
\text { LM and accept only NTLM and } \\
\text { NTLMv2 authentication. } \\
\text { Send NTLMv2 response } \\
\text { onlylrefuse LM \& NTLM: } \\
\text { Clients use NTLMv2 } \\
\text { authentication only and use } \\
\text { NTLMv2 session security if the } \\
\text { server supports it. DCs refuse } \\
\text { LM and NTLM, and accept } \\
\text { only NTLMv2 authentication. }\end{array}$ & & \\
\hline $\begin{array}{l}\text { Message text for } \\
\text { users attempting to } \\
\text { log on }\end{array}$ & $\begin{array}{l}\text { The body (text) of the logon banner } \\
\text { seen before viewing the login dialog } \\
\text { box. See Appendix C DOE Login } \\
\text { Banner. }\end{array}$ & $\begin{array}{l}\text { DOE login } \\
\text { banner text. See } \\
\text { Appendix C } \\
\text { DOE Login } \\
\text { Banner. } \\
\end{array}$ & $\begin{array}{l}\text { DOE login } \\
\text { banner text. See } \\
\text { Appendix C } \\
\text { DOE Login } \\
\text { Banner } \\
\end{array}$ \\
\hline $\begin{array}{l}\text { Message title for } \\
\text { users attempting to } \\
\text { log on }\end{array}$ & $\begin{array}{l}\text { The title (text) of the logon banner } \\
\text { dialog box. See Appendix C DOE } \\
\text { Login Banner. }\end{array}$ & Notice To Users & Notice To Users \\
\hline $\begin{array}{l}\text { Number of } \\
\text { previous logons to } \\
\text { cache (in case } \\
\text { domain controller } \\
\text { is not available) }\end{array}$ & $\begin{array}{l}\text { User credentials from this many } \\
\text { previous logons are cached and used } \\
\text { in the event that a domain controller } \\
\text { is not available. }\end{array}$ & 10 logons & 10 logons \\
\hline $\begin{array}{l}\text { Prevent system } \\
\text { maintenance of } \\
\text { computer account } \\
\text { password }\end{array}$ & $\begin{array}{l}\text { Prevents the password of the } \\
\text { computer account from being } \\
\text { changed every seven days. }\end{array}$ & Disabled & Disabled \\
\hline $\begin{array}{l}\text { Prevent users from } \\
\text { installing printer } \\
\text { drivers }\end{array}$ & $\begin{array}{l}\text { Prevents members of the Users } \\
\text { group from installing printer drivers. }\end{array}$ & Disabled & Disabled \\
\hline $\begin{array}{l}\text { Prompt user to } \\
\text { change password } \\
\text { before expiration }\end{array}$ & $\begin{array}{l}\text { The number of days of advanced } \\
\text { warning to give computer users } \\
\text { about an impending expiring } \\
\text { password. }\end{array}$ & 14 days & 14 days \\
\hline Recovery Console: & Allows login to the recovery console & Disabled & Disabled \\
\hline
\end{tabular}




\begin{tabular}{|c|c|c|c|}
\hline $\begin{array}{l}\text { Allow automatic } \\
\text { administrative } \\
\text { logon }\end{array}$ & $\begin{array}{l}\text { without an administrator password. } \\
\text { The Recovery Console is a system } \\
\text { repair option that can be installed as } \\
\text { an NT Loader boot option. }\end{array}$ & & \\
\hline $\begin{array}{l}\text { Recovery Console: } \\
\text { Allow floppy copy } \\
\text { and access to all } \\
\text { drives and all } \\
\text { folders }\end{array}$ & $\begin{array}{l}\text { Enables the recovery console's SET } \\
\text { command so that you can enable } \\
\text { wildcard support, enable access to } \\
\text { all files, enable access to removable } \\
\text { media, and disable the prompt when } \\
\text { overwriting a file. }\end{array}$ & Disabled & Disabled \\
\hline $\begin{array}{l}\text { Rename } \\
\text { administrator } \\
\text { account }\end{array}$ & $\begin{array}{l}\text { Change the account designated as } \\
\text { the computer Administrator account } \\
\text { to make it more difficult for } \\
\text { intruders to attack a system. Don't } \\
\text { put a value here in a template you } \\
\text { are going to apply to many machines } \\
\text { or you will change the name of the } \\
\text { Administrator account on every } \\
\text { machine to the same value. }\end{array}$ & Not defined & Not defined \\
\hline $\begin{array}{l}\text { Rename guest } \\
\text { account }\end{array}$ & $\begin{array}{l}\text { Change the account designated as } \\
\text { the Guest account to make it more } \\
\text { difficult for intruders to attack a } \\
\text { system. Don't put a value here in a } \\
\text { template that is going to be applied } \\
\text { to many machines or you will } \\
\text { change the name of the Guest } \\
\text { account on every machine to the } \\
\text { same name. }\end{array}$ & Not defined & Not defined \\
\hline $\begin{array}{l}\text { Restrict CD-ROM } \\
\text { access to locally } \\
\text { logged-on user } \\
\text { only }\end{array}$ & $\begin{array}{l}\text { Prevents the CD-ROM from being } \\
\text { shared over the network. }\end{array}$ & Disabled & Disabled \\
\hline $\begin{array}{l}\text { Restrict floppy } \\
\text { access to locally } \\
\text { logged-on user } \\
\text { only }\end{array}$ & $\begin{array}{l}\text { Prevents the floppy disk from being } \\
\text { shared over the network. }\end{array}$ & Disabled & Disabled \\
\hline $\begin{array}{l}\text { Secure channel: } \\
\text { Digitally encrypt } \\
\text { or sign secure } \\
\text { channel data } \\
\text { (always) }\end{array}$ & $\begin{array}{l}\text { Requires that the secure channel } \\
\text { between the computer and the } \\
\text { domain server encrypt or sign the } \\
\text { data in the channel. Set this only if } \\
\text { all servers in a domain support } \\
\text { secure channel encryption. } \\
\text { Automatically enables "Secure } \\
\text { channel: Digitally sign secure } \\
\text { channel data (when possible)" when } \\
\text { enabled. }\end{array}$ & Disabled & Disabled \\
\hline
\end{tabular}




\begin{tabular}{|c|c|c|c|}
\hline $\begin{array}{l}\text { Secure channel: } \\
\text { Digitally encrypt } \\
\text { secure channel } \\
\text { data (when } \\
\text { possible) }\end{array}$ & $\begin{array}{l}\text { Encrypt the secure channel between } \\
\text { a computer and the domain server } \\
\text { when possible. Enable this to use the } \\
\text { highest encryption possible when a } \\
\text { computer communicates with a } \\
\text { server using the secure channel. } \\
\text { Automatically enables "Secure } \\
\text { channel: Digitally sign secure } \\
\text { channel data (when possible)" when } \\
\text { enabled. }\end{array}$ & Enabled & Enabled \\
\hline $\begin{array}{l}\text { Secure channel: } \\
\text { Digitally sign } \\
\text { secure channel } \\
\text { data (when } \\
\text { possible) }\end{array}$ & $\begin{array}{l}\text { Sign the secure channel between a } \\
\text { computer and the domain server } \\
\text { when possible. Enable this to } \\
\text { increase the authentication of the } \\
\text { secure channel to a server. This is } \\
\text { automatically enabled if "Secure } \\
\text { channel: Digitally encrypt secure } \\
\text { channel data (when possible)" or } \\
\text { "Secure channel: Digitally encrypt } \\
\text { or sign secure channel data } \\
\text { (always)" are enabled. }\end{array}$ & Enabled & Enabled \\
\hline $\begin{array}{l}\text { Secure channel: } \\
\text { Require strong } \\
\text { (Windows } 2000 \text { or } \\
\text { later) session key }\end{array}$ & $\begin{array}{l}\text { Requires the use of strong } \\
\text { encryption in the secure channel } \\
\text { between a computer and a server. } \\
\text { Only enable if all trusted domain } \\
\text { controllers can handle strong } \\
\text { encryption. }\end{array}$ & Disabled & Disabled \\
\hline $\begin{array}{l}\text { Secure system } \\
\text { partition (for RISC } \\
\text { platforms only) }\end{array}$ & $\begin{array}{l}\text { Prevent access to the system } \\
\text { partition of RISC platform to all but } \\
\text { the Administrator. This applies only } \\
\text { to RISC systems. }\end{array}$ & Enabled & Enabled \\
\hline $\begin{array}{l}\text { Send unencrypted } \\
\text { password to } \\
\text { connect to third- } \\
\text { party SMB servers }\end{array}$ & $\begin{array}{l}\text { Send unencrypted passwords to } \\
\text { older SMB (Windows networking) } \\
\text { servers. This should not be enabled } \\
\text { unless there is no other way to } \\
\text { connect to the older SMB servers. }\end{array}$ & Disabled & Disabled \\
\hline $\begin{array}{l}\text { Shut down system } \\
\text { immediately if } \\
\text { unable to log } \\
\text { security audits }\end{array}$ & $\begin{array}{l}\text { Enabling this causes a system to be } \\
\text { halted if a security log cannot be } \\
\text { written. Security log failures are } \\
\text { usually caused by the security log } \\
\text { being full. Be careful when enabling } \\
\text { this on a server. This can also be set } \\
\text { in Event Log/Settings for Event } \\
\text { Logs. }\end{array}$ & Disabled & Disabled \\
\hline $\begin{array}{l}\text { Smart card } \\
\text { removal behavior }\end{array}$ & $\begin{array}{l}\text { Determine the behavior of a system } \\
\text { when the logged in users smart card }\end{array}$ & $\begin{array}{l}\text { Lock } \\
\text { Workstation }\end{array}$ & $\begin{array}{l}\text { Lock } \\
\text { Workstation } \\
\end{array}$ \\
\hline
\end{tabular}




\begin{tabular}{|c|c|c|c|}
\hline & $\begin{array}{l}\text { is removed. The options are: } \\
\text { - No Action } \\
\text { - Lock Workstation } \\
\text { - Force Logoff } \\
\end{array}$ & & \\
\hline $\begin{array}{l}\text { Strengthen default } \\
\text { permissions of } \\
\text { global system } \\
\text { objects (e.g. } \\
\text { Symbolic Links) }\end{array}$ & $\begin{array}{l}\text { When enabled, shared system } \\
\text { resources such as DOS names and } \\
\text { semaphores can be read but not } \\
\text { changed by non-Administrator users } \\
\text { that created them. Disabling it } \\
\text { allows non-Administrator users to } \\
\text { change objects they create. }\end{array}$ & Enabled & Enabled \\
\hline $\begin{array}{l}\text { Unsigned driver } \\
\text { installation } \\
\text { behavior }\end{array}$ & $\begin{array}{l}\text { Determines the behavior of a system } \\
\text { when there is an attempt to install an } \\
\text { unsigned device driver. The options } \\
\text { are: } \\
\text { - Silently succeed } \\
\text { - Warn but allow installation } \\
\text { - Do not allow installation } \\
\text { You may need to change this } \\
\text { behavior if you must use an } \\
\text { unsigned driver and you trust the } \\
\text { driver. }\end{array}$ & $\begin{array}{l}\text { Do not allow } \\
\text { installation }\end{array}$ & $\begin{array}{l}\text { Do not allow } \\
\text { installation }\end{array}$ \\
\hline $\begin{array}{l}\text { Unsigned non- } \\
\text { driver installation } \\
\text { behavior }\end{array}$ & $\begin{array}{l}\text { Determines the behavior of a system } \\
\text { when unsigned software (other than } \\
\text { drivers) is installed on a system. The } \\
\text { options are: } \\
\text { - Silently succeed } \\
\text { - Warn but allow installation } \\
\text { - Do not allow installation }\end{array}$ & Silently succeed & Silently succeed \\
\hline
\end{tabular}

\section{EVENT Log/SETTINGS FOR EVENT LogS}

\begin{tabular}{|l|l|l|l|}
\hline Policy & Description & Iforh station & IC Setting \\
\hline $\begin{array}{l}\text { Maximum } \\
\text { application log size }\end{array}$ & $\begin{array}{l}\text { Sets the maximum size for the } \\
\text { application log file. }\end{array}$ & 2048 kilobytes & 2048 kilobytes \\
\hline $\begin{array}{l}\text { Maximum security } \\
\text { log size }\end{array}$ & $\begin{array}{l}\text { Sets the maximum size for the } \\
\text { security log file. }\end{array}$ & 2048 kilobytes & 2048 kilobytes \\
\hline $\begin{array}{l}\text { Maximum system } \\
\text { log size }\end{array}$ & $\begin{array}{l}\text { Sets the maximum size of the system } \\
\text { log file. }\end{array}$ & 2048 kilobytes & 2048 kilobytes \\
\hline $\begin{array}{l}\text { Restrict guest } \\
\text { access to } \\
\text { application log }\end{array}$ & $\begin{array}{l}\text { Prevents the guest account from } \\
\text { accessing the application log. }\end{array}$ & Enabled & Enabled \\
\hline $\begin{array}{l}\text { Restrict guest } \\
\text { access to security }\end{array}$ & $\begin{array}{l}\text { Prevents the guest account from } \\
\text { accessing the security log. }\end{array}$ & Enabled & Enabled \\
\hline
\end{tabular}




\begin{tabular}{|c|c|c|c|}
\hline $\log$ & & & \\
\hline $\begin{array}{l}\text { Restrict guest } \\
\text { access to system } \\
\text { log }\end{array}$ & $\begin{array}{l}\text { Prevents the guest account from } \\
\text { accessing the system log. }\end{array}$ & Enabled & Enabled \\
\hline $\begin{array}{l}\text { Retain application } \\
\log \end{array}$ & $\begin{array}{l}\text { If the retention method for the } \\
\text { application log is "By days", list the } \\
\text { number of days of log data to } \\
\text { maintain in the file. }\end{array}$ & Not Defined & Not Defined \\
\hline Retain security log & $\begin{array}{l}\text { If the retention method for the } \\
\text { security log is "By days", list the } \\
\text { number of days of log data to } \\
\text { maintain in the file. }\end{array}$ & Not Defined & Not Defined \\
\hline Retain system log & $\begin{array}{l}\text { If the retention method for the } \\
\text { system log is "By days", list the } \\
\text { number of days of log data to } \\
\text { maintain in the file. }\end{array}$ & Not Defined & Not Defined \\
\hline $\begin{array}{l}\text { Retention method } \\
\text { for application log }\end{array}$ & $\begin{array}{l}\text { Set the method for wrapping the } \\
\text { application log file. The options are: } \\
\text { Overwrite events as needed } \\
\text { Overwrite old events only when } \\
\text { the space is needed for new } \\
\text { events. } \\
\text { - Overwrite events by days } \\
\text { Delete events older than the } \\
\text { number of days set in "Retain } \\
\text { application log." } \\
\text { Do not overwrite events } \\
\text { Do not overwrite any events. } \\
\text { When the log file fills, generate } \\
\text { an error. }\end{array}$ & As needed & As needed \\
\hline $\begin{array}{l}\text { Retention method } \\
\text { for security log }\end{array}$ & $\begin{array}{l}\text { Set the method for wrapping the } \\
\text { application log file. The options are: } \\
\text { - Overwrite events as needed } \\
\text { Overwrite old events only when } \\
\text { the space is needed for new } \\
\text { events. } \\
\text { - Overwrite events by days } \\
\text { Delete events older than the } \\
\text { number of days set in "Retain } \\
\text { application log." } \\
\text { Do not overwrite events } \\
\text { Do not overwrite any events. } \\
\text { When the log file fills, generate } \\
\text { an error or shut down the } \\
\text { system. See "Shut down the }\end{array}$ & As needed & As needed \\
\hline
\end{tabular}




\begin{tabular}{|c|c|c|c|}
\hline & $\begin{array}{l}\text { computer when the security } \\
\text { audit log is full." }\end{array}$ & & \\
\hline $\begin{array}{l}\text { Retention method } \\
\text { for system log }\end{array}$ & $\begin{array}{l}\text { Set the method for wrapping the } \\
\text { application log file. The options are: } \\
\text { - As needed - Overwrite events } \\
\text { as needed } \\
\text { Overwrite old events only when } \\
\text { the space is needed for new } \\
\text { events. } \\
\text { - By days - Overwrite events by } \\
\text { days } \\
\text { Delete events older than the } \\
\text { number of days set in "Retain } \\
\text { application log." } \\
\text { Manually - Do not overwrite } \\
\text { events (clear manually) } \\
\text { Do not overwrite any events. } \\
\text { When the log file fills, generate } \\
\text { an error. }\end{array}$ & As needed & As needed \\
\hline $\begin{array}{l}\text { Shut down the } \\
\text { computer when the } \\
\text { security audit log } \\
\text { is full }\end{array}$ & $\begin{array}{l}\text { Don't use. Use "Shut down system } \\
\text { immediately if unable to log security } \\
\text { audits" in Local Policies/Security } \\
\text { Options instead. Enabling this } \\
\text { causes a system to be halted when } \\
\text { the security log is full. }\end{array}$ & Disabled & Disabled \\
\hline
\end{tabular}

\section{RESTRICTED GROUPS}

Members are the users who are in a group and Members Of are the groups this group is a member of. Most of these are not set in the templates as the settings tend to be site specific and the template will overwrite whatever users are already defined for the groups. Windows 2000 will not let you overwrite everything. For example, the Administrator is always a member of the Administrators group. If you try to remove him with this template, Windows 2000 will put him back.

\begin{tabular}{|l|l|l|}
\hline (iroup Name & \multicolumn{1}{|l|}{ Nembers } & Nember ()f \\
\hline Administrators & Not defined & Not defined \\
\hline Backup Operators & Not defined & Not defined \\
\hline Guests & Not defined & Not defined \\
\hline Power Users & Not defined & Not defined \\
\hline Replicator & Not defined & Not defined \\
\hline Users & Not defined & Not defined \\
\hline
\end{tabular}




\section{SYSTEM SERVICES}

System services are all the services running on the current system. On a single computer, system services are configured using the Services control panel. Using the System Services policy, you can override the control panel settings. In addition, you cans set the permissions and auditing for each service. Startup options are,

- Automatic - The service starts automatically when needed.

- Manual - The Service must be manually started by an application.

- Disabled - The service cannot be started.

The permission codes used in the template files are,

- CC - Query template

- DC - Change template

- LC - Query status

- SW - Enumerate dependents

- RP - Start

- WP - Stop

- DT - Pause and continue

- LO - Interrogate

- CR - User-defined control

- SD - Delete

- RC - Read permissions

- WD - Change permissions

- WO - Take ownership

These permissions are grouped as the following,

- $\operatorname{Read}=\mathrm{CC}, \mathrm{LC}, \mathrm{SW}, \mathrm{LO}, \mathrm{CR}, \mathrm{RC}$

- Read - CR = CC, LC, SW, LO, RC

- Write = DC, RC

- Start, stop, and pause = RP, WP, DT, RC

- Delete = SD

- Full Control = CC, DC, LS, SW, RP, WP, DT, LO, CR, SD, RC, WE, WO

\section{Workstation Settings}

\begin{tabular}{|c|c|c|c|}
\hline Service Name & Startup & Permission & Auditing \\
\hline $\begin{array}{l}\text { Application } \\
\text { Management }\end{array}$ & Manual & $\begin{array}{l}\text { Authenticated Users: Read - } \\
\text { CR } \\
\text { Administrators: Full Control } \\
\text { Power Users: Read - CR } \\
\text { INTERACTIVE: Read - CR - } \\
\text { RC + Start } \\
\text { Users: Read - CR - RC + Start }\end{array}$ & Everyone: Fail, Full Control \\
\hline ClipBook & Manual & $\begin{array}{l}\text { Authenticated Users: Read - } \\
\text { CR } \\
\text { Administrators: Full Control } \\
\text { Power Users: Read - CR } \\
\text { INTERACTIVE: Read - CR - }\end{array}$ & Everyone: Fail, Full Control \\
\hline
\end{tabular}




\begin{tabular}{|c|c|c|c|}
\hline & & $\mathrm{RC}+$ Start & \\
\hline $\begin{array}{l}\text { Computer } \\
\text { Browser }\end{array}$ & Automatic & $\begin{array}{l}\text { Authenticated Users: Read } \\
\text { Power Users: Read + Start } \\
\text { Administrators: Full Control } \\
\text { SYSTEM: Read + Start + Stop } \\
\text { + Pause }\end{array}$ & Everyone: Fail, Full Control \\
\hline DHCP Client & Automatic & $\begin{array}{l}\text { Authenticated Users: Read } \\
\text { Power Users: Read + Start } \\
\text { Administrators: Full Control } \\
\text { SYSTEM: Read + Start + Stop } \\
\text { + Pause }\end{array}$ & Everyone: Fail, Full Control \\
\hline $\begin{array}{l}\text { Distributed } \\
\text { Link Tracking } \\
\text { Client }\end{array}$ & Automatic & $\begin{array}{l}\text { Authenticated Users: Read } \\
\text { Power Users: Read + Start } \\
\text { Administrators: Full Control } \\
\text { SYSTEM: Read + Start + Stop } \\
\text { + Pause }\end{array}$ & Everyone: Fail, Full Control \\
\hline DNS Client & Automatic & $\begin{array}{l}\text { Authenticated Users: Read } \\
\text { Power Users: Read + Start } \\
\text { Administrators: Full Control } \\
\text { SYSTEM: Read + Start + Stop } \\
+ \text { + Pause }\end{array}$ & Everyone: Fail, Full Control \\
\hline Event Log & Automatic & $\begin{array}{l}\text { Authenticated Users: Read } \\
\text { Power Users: Read + Start } \\
\text { Administrators: Full Control } \\
\text { SYSTEM: Read + Start + Stop } \\
\text { + Pause }\end{array}$ & Everyone: Fail, Full Control \\
\hline $\begin{array}{l}\text { IPSEC Policy } \\
\text { Agent }\end{array}$ & Automatic & $\begin{array}{l}\text { (A;;CCLCSWLORC;;;AU) } \\
\text { Power Users: Read + Start } \\
\text { Administrators: Full Control } \\
\text { SYSTEM: Read + Start + Stop } \\
\text { + Pause }\end{array}$ & Everyone: Fail, Full Control \\
\hline $\begin{array}{l}\text { Logical Disk } \\
\text { Manager }\end{array}$ & Automatic & $\begin{array}{l}\text { Authenticated Users: Read } \\
\text { Power Users: Read + Start } \\
\text { Administrators: Full Control } \\
\text { SYSTEM: Read + Start + Stop } \\
\text { + Pause }\end{array}$ & Everyone: Fail, Full Control \\
\hline Messenger & Automatic & $\begin{array}{l}\text { Authenticated Users: Read } \\
\text { Power Users: Read + Start } \\
\text { Administrators: Full Control } \\
\text { SYSTEM: Read + Start + Stop } \\
\text { + Pause }\end{array}$ & Everyone: Fail, Full Control \\
\hline Net Logon & Automatic & $\begin{array}{l}\text { Authenticated Users: Read } \\
\text { Power Users: Read + Start } \\
\text { Administrators: Full Control } \\
\text { SYSTEM: Read + Start + Stop } \\
\text { + Pause } \\
\end{array}$ & Everyone: Fail, Full Control \\
\hline
\end{tabular}




\begin{tabular}{|c|c|c|c|}
\hline Network DDE & Manual & $\begin{array}{l}\text { Authenticated Users: Read - } \\
\text { CR } \\
\text { Administrators: Full Control } \\
\text { Power Users: Read - CR } \\
\text { INTERACTIVE: Read - CR - } \\
\text { RC + Start } \\
\end{array}$ & Everyone: Fail, Full Control \\
\hline $\begin{array}{l}\text { Network DDE } \\
\text { DSDM }\end{array}$ & Manual & $\begin{array}{l}\text { D:Authenticated Users: Read - } \\
\text { CR } \\
\text { Administrators: Full Control } \\
\text { Power Users: Read - CR } \\
\text { INTERACTIVE: Read - CR - } \\
\text { RC + Start }\end{array}$ & Everyone: Fail, Full Control \\
\hline Plug and Play & Automatic & $\begin{array}{l}\text { Authenticated Users: Read } \\
\text { Power Users: Read + Start } \\
\text { Administrators: Full Control } \\
\text { SYSTEM: Read + Start + Stop } \\
\text { + Pause }\end{array}$ & Everyone: Fail, Full Control \\
\hline Print Spooler & Automatic & $\begin{array}{l}\text { Authenticated Users: Read } \\
\text { Power Users: Read + Start } \\
\text { Administrators: Full Control } \\
\text { SYSTEM: Read + Start + Stop } \\
\text { + Pause }\end{array}$ & Everyone: Fail, Full Control \\
\hline $\begin{array}{l}\text { Protected } \\
\text { Storage }\end{array}$ & Automatic & $\begin{array}{l}\text { Authenticated Users: Read } \\
\text { Power Users: Read + Start } \\
\text { Administrators: Full Control } \\
\text { SYSTEM: Read + Start + Stop } \\
\text { + Pause } \\
\end{array}$ & Everyone: Fail, Full Control \\
\hline $\begin{array}{l}\text { Remote } \\
\text { Procedure Call } \\
\text { (RPC) }\end{array}$ & Automatic & $\begin{array}{l}\text { Authenticated Users: Read - } \\
\text { CR } \\
\text { Administrators: Full Control } \\
\text { Power Users: Read - CR } \\
\text { INTERACTIVE: Read - CR - } \\
\text { RC + Start } \\
\text { Users: Read - CR - RC + Start }\end{array}$ & Everyone: Fail, Full Control \\
\hline $\begin{array}{l}\text { Remote } \\
\text { Registry } \\
\text { Service }\end{array}$ & Automatic & $\begin{array}{l}\text { Authenticated Users: Read } \\
\text { Power Users: Read + Start } \\
\text { Administrators: Full Control } \\
\text { SYSTEM: Read + Start + Stop } \\
\text { + Pause }\end{array}$ & Everyone: Fail, Full Control \\
\hline $\begin{array}{l}\text { Removable } \\
\text { Storage }\end{array}$ & Automatic & $\begin{array}{l}\text { Administrators: Full Control } \\
\text { Authenticated Users: Read } \\
\text { Power Users: Read+Start } \\
\text { SYSTEM: Read + Start + Stop } \\
\text { + Pause }\end{array}$ & Everyone: Fail, Full Control \\
\hline $\begin{array}{l}\text { RunAs } \\
\text { Service }\end{array}$ & Automatic & $\begin{array}{l}\text { Administrators: Full Control } \\
\text { Authenticated Users: Read }\end{array}$ & Everyone: Fail, Full Control \\
\hline
\end{tabular}




\begin{tabular}{|c|c|c|c|}
\hline & & $\begin{array}{l}\text { Power Users: Read+Start } \\
\text { SYSTEM: Read + Start + Stop } \\
\text { + Pause }\end{array}$ & \\
\hline $\begin{array}{l}\text { Security } \\
\text { Accounts } \\
\text { Manager }\end{array}$ & Automatic & $\begin{array}{l}\text { Authenticated Users: Read - } \\
\text { CR } \\
\text { Administrators: Full Control } \\
\text { Power Users: Read - CR } \\
\text { INTERACTIVE: Read - CR - } \\
\text { RC + Start } \\
\text { Users: Read - CR - RC + Start }\end{array}$ & Everyone: Fail, Full Control \\
\hline Server & Automatic & $\begin{array}{l}\text { Authenticated Users: Read } \\
\text { Power Users: Read + Start } \\
\text { Administrators: Full Control } \\
\text { SYSTEM: Read + Start + Stop } \\
\text { + Pause }\end{array}$ & Everyone: Fail, Full Control \\
\hline $\begin{array}{l}\text { System Event } \\
\text { Notification }\end{array}$ & Automatic & $\begin{array}{l}\text { Authenticated Users: Read } \\
\text { Power Users: Read + Start } \\
\text { Administrators: Full Control } \\
\text { SYSTEM: Read + Start + Stop } \\
\text { + Pause }\end{array}$ & Everyone: Fail, Full Control \\
\hline $\begin{array}{l}\text { Task } \\
\text { Scheduler }\end{array}$ & Automatic & $\begin{array}{l}\text { Authenticated Users: Read } \\
\text { Power Users: Read + Start } \\
\text { Administrators: Full Control } \\
\text { SYSTEM: Read + Start + Stop } \\
\text { + Pause } \\
\end{array}$ & Everyone: Fail, Full Control \\
\hline $\begin{array}{l}\text { TCP/IP } \\
\text { NetBIOS } \\
\text { Helper Service }\end{array}$ & Automatic & $\begin{array}{l}\text { Authenticated Users: Read } \\
\text { Power Users: Read + Start } \\
\text { Administrators: Full Control } \\
\text { SYSTEM: Read + Start + Stop } \\
\text { + Pause }\end{array}$ & Everyone: Fail, Full Control \\
\hline $\begin{array}{l}\text { Windows } \\
\text { Time }\end{array}$ & Automatic & $\begin{array}{l}\text { Authenticated Users: Read - } \\
\text { CR } \\
\text { Administrators: Full Control } \\
\text { Power Users: Read - CR } \\
\text { INTERACTIVE: Read - CR - } \\
\text { RC + Start } \\
\text { Users: Read - CR - RC + Start }\end{array}$ & \\
\hline Workstation & Automatic & $\begin{array}{l}\text { Authenticated Users: Read } \\
\text { Power Users: Read + Start } \\
\text { Administrators: Full Control } \\
\text { SYSTEM: Read + Start + Stop } \\
\text { + Pause }\end{array}$ & Everyone: Fail, Full Control \\
\hline
\end{tabular}


Server Settings

\begin{tabular}{|c|c|c|c|}
\hline Service Name & Startup & Permission & Auditing \\
\hline Alerter & Automatic & $\begin{array}{l}\text { Authenticated Users: Read } \\
\text { Power Users: Read + Start } \\
\text { Administrators: Full Control } \\
\text { Server Operators: Full Control } \\
\text { SYSTEM: Read + Start + Stop } \\
\text { + Pause }\end{array}$ & Everyone: Fail, Full Control \\
\hline $\begin{array}{l}\text { Application } \\
\text { Management }\end{array}$ & Manual & $\begin{array}{l}\text { Authenticated Users: Read - } \\
\text { CR } \\
\text { Administrators: Full Control } \\
\text { Power Users: Read - CR } \\
\text { INTERACTIVE: Read - CR - } \\
\text { RC + Start } \\
\text { Users: Read - CR - RC + Start }\end{array}$ & Everyone: Fail, Full Control \\
\hline ClipBook & Manual & $\begin{array}{l}\text { Authenticated Users: Read - } \\
\text { CR } \\
\text { Administrators: Full Control } \\
\text { Server Operators: Full Control } \\
\text { Power Users: Read - CR } \\
\text { INTERACTIVE: Read - CR - } \\
\text { RC + Start }\end{array}$ & Everyone: Fail, Full Control \\
\hline $\begin{array}{l}\text { Computer } \\
\text { Browser }\end{array}$ & Automatic & $\begin{array}{l}\text { Authenticated Users: Read } \\
\text { Power Users: Read + Start } \\
\text { Administrators: Full Control } \\
\text { Server Operators: Full Control } \\
\text { SYSTEM: Read + Start + Stop } \\
\text { + Pause }\end{array}$ & Everyone: Fail, Full Control \\
\hline DFS & Automatic & $\begin{array}{l}\text { Authenticated Users: Read } \\
\text { Power Users: Read + Start } \\
\text { Administrators: Full Control } \\
\text { Server Operators: Full Control } \\
\text { SYSTEM: Read + Start + Stop } \\
\text { + Pause }\end{array}$ & Everyone: Fail, Full Control \\
\hline DHCP Client & Automatic & $\begin{array}{l}\text { Authenticated Users: Read } \\
\text { Power Users: Read + Start } \\
\text { Administrators: Full Control } \\
\text { Server Operators: Full Control } \\
\text { SYSTEM: Read + Start + Stop } \\
\text { + Pause }\end{array}$ & Everyone: Fail, Full Control \\
\hline $\begin{array}{l}\text { Distributed } \\
\text { Transaction } \\
\text { Coordinator }\end{array}$ & Automatic & $\begin{array}{l}\text { Authenticated Users: Read } \\
\text { Power Users: Read + Start } \\
\text { Administrators: Full Control } \\
\text { Server Operators: Full Control } \\
\text { SYSTEM: Read + Start + Stop }\end{array}$ & Everyone: Fail, Full Control \\
\hline
\end{tabular}




\begin{tabular}{|c|c|c|c|}
\hline & & $\begin{array}{l}\text { + Pause } \\
\text { Authenticated Users: Start }\end{array}$ & \\
\hline $\begin{array}{l}\text { Distributed } \\
\text { Link Tracking } \\
\text { Client }\end{array}$ & Automatic & $\begin{array}{l}\text { Authenticated Users: Read } \\
\text { Power Users: Read + Start } \\
\text { Administrators: Full Control } \\
\text { Server Operators: Full Control } \\
\text { SYSTEM: Read + Start + Stop } \\
\text { + Pause }\end{array}$ & Everyone: Fail, Full Control \\
\hline DNS Client & Automatic & $\begin{array}{l}\text { Authenticated Users: Read } \\
\text { Power Users: Read + Start } \\
\text { Administrators: Full Control } \\
\text { Server Operators: Full Control } \\
\text { SYSTEM: Read + Start + Stop } \\
\text { + Pause }\end{array}$ & Everyone: Fail, Full Control \\
\hline Event Log & Automatic & $\begin{array}{l}\text { Authenticated Users: Read } \\
\text { Power Users: Read + Start } \\
\text { Administrators: Full Control } \\
\text { Server Operators: Full Control } \\
\text { SYSTEM: Read + Start + Stop } \\
\text { + Pause } \\
\end{array}$ & Everyone: Fail, Full Control \\
\hline $\begin{array}{l}\text { IPSEC Policy } \\
\text { Agent }\end{array}$ & Automatic & $\begin{array}{l}\text { Authenticated Users: Read - } \\
\text { CR } \\
\text { Power Users: Read + Start } \\
\text { Administrators: Full Control } \\
\text { Server Operators: Full Control } \\
\text { SYSTEM: Read + Start + Stop } \\
\text { + Pause }\end{array}$ & Everyone: Fail, Full Control \\
\hline License Agent & Automatic & $\begin{array}{l}\text { Authenticated Users: Read } \\
\text { Power Users: Read + Start } \\
\text { Administrators: Full Control } \\
\text { Server Operators: Full Control } \\
\text { SYSTEM: Read + Start + Stop } \\
\text { + Pause } \\
\end{array}$ & Everyone: Fail, Full Control \\
\hline $\begin{array}{l}\text { Logical Disk } \\
\text { Manager }\end{array}$ & Automatic & $\begin{array}{l}\text { Authenticated Users: Read } \\
\text { Power Users: Read + Start } \\
\text { Administrators: Full Control } \\
\text { Server Operators: Full Control } \\
\text { SYSTEM: Read + Start + Stop } \\
\text { + Pause }\end{array}$ & Everyone: Fail, Full Control \\
\hline Messenger & Automatic & $\begin{array}{l}\text { Authenticated Users: Read } \\
\text { Power Users: Read + Start } \\
\text { Administrators: Full Control } \\
\text { Server Operators: Full Control } \\
\text { SYSTEM: Read + Start + Stop } \\
\text { + Pause }\end{array}$ & Everyone: Fail, Full Control \\
\hline Net Logon & Automatic & Authenticated Users: Read & Everyone: Fail, Full Control \\
\hline
\end{tabular}




\begin{tabular}{|c|c|c|c|}
\hline & & $\begin{array}{l}\text { Power Users: Read + Start } \\
\text { Administrators: Full Control } \\
\text { Server Operators: Full Control } \\
\text { SYSTEM: Read + Start + Stop } \\
\text { + Pause }\end{array}$ & \\
\hline Network DDE & Manual & $\begin{array}{l}\text { Authenticated Users: Read - } \\
\text { CR } \\
\text { Administrators: Full Control } \\
\text { Server Operators: Full Control } \\
\text { Power Users: Read - CR } \\
\text { INTERACTIVE: Read - CR - } \\
\text { RC + Start }\end{array}$ & Everyone: Fail, Full Control \\
\hline $\begin{array}{l}\text { Network DDE } \\
\text { DSDM }\end{array}$ & Manual & $\begin{array}{l}\text { D:Authenticated Users: Read - } \\
\text { CR } \\
\text { Administrators: Full Control } \\
\text { Server Operators: Full Control } \\
\text { Power Users: Read - CR } \\
\text { INTERACTIVE: Read - CR - } \\
\text { RC + Start }\end{array}$ & Everyone: Fail, Full Control \\
\hline Plug and Play & Automatic & $\begin{array}{l}\text { Authenticated Users: Read } \\
\text { Power Users: Read + Start } \\
\text { Administrators: Full Control } \\
\text { Server Operators: Full Control } \\
\text { SYSTEM: Read + Start + Stop } \\
\text { + Pause } \\
\end{array}$ & Everyone: Fail, Full Control \\
\hline Print Spooler & Automatic & $\begin{array}{l}\text { Authenticated Users: Read } \\
\text { Power Users: Read + Start } \\
\text { Administrators: Full Control } \\
\text { Server Operators: Full Control } \\
\text { SYSTEM: Read + Start + Stop } \\
\text { + Pause } \\
\end{array}$ & Everyone: Fail, Full Control \\
\hline $\begin{array}{l}\text { Protected } \\
\text { Storage }\end{array}$ & Automatic & $\begin{array}{l}\text { Authenticated Users: Read } \\
\text { Power Users: Read + Start } \\
\text { Administrators: Full Control } \\
\text { Server Operators: Full Control } \\
\text { SYSTEM: Read + Start + Stop } \\
\text { + Pause } \\
\end{array}$ & Everyone: Fail, Full Control \\
\hline $\begin{array}{l}\text { Remote } \\
\text { Procedure Call } \\
\text { (RPC) }\end{array}$ & Automatic & $\begin{array}{l}\text { Authenticated Users: Read - } \\
\text { CR } \\
\text { Administrators: Full Control } \\
\text { Power Users: Read - CR } \\
\text { INTERACTIVE: Read - CR - } \\
\text { RC + Start } \\
\text { Users: Read - CR - RC + Start }\end{array}$ & Everyone: Fail, Full Control \\
\hline $\begin{array}{l}\text { Remote } \\
\text { Registry }\end{array}$ & Automatic & $\begin{array}{l}\text { Authenticated Users: Read } \\
\text { Power Users: Read + Start }\end{array}$ & Everyone: Fail, Full Control \\
\hline
\end{tabular}




\begin{tabular}{|c|c|c|c|}
\hline Service & & $\begin{array}{l}\text { Administrators: Full Control } \\
\text { Server Operators: Full Control } \\
\text { SYSTEM: Read + Start + Stop } \\
\text { + Pause }\end{array}$ & \\
\hline $\begin{array}{l}\text { Removable } \\
\text { Storage }\end{array}$ & Automatic & $\begin{array}{l}\text { Administrators: Full Control } \\
\text { Authenticated Users: Read } \\
\text { Power Users: Read+Start } \\
\text { Server Operators: Full Control } \\
\text { SYSTEM: Read + Start + Stop } \\
\text { + Pause }\end{array}$ & Everyone: Fail, Full Control \\
\hline $\begin{array}{l}\text { RunAs } \\
\text { Service }\end{array}$ & Automatic & $\begin{array}{l}\text { Administrators: Full Control } \\
\text { Server Operators: Full Control } \\
\text { Authenticated Users: Read } \\
\text { Power Users: Read+Start } \\
\text { SYSTEM: Read + Start + Stop } \\
\text { + Pause }\end{array}$ & Everyone: Fail, Full Control \\
\hline $\begin{array}{l}\text { Security } \\
\text { Accounts } \\
\text { Manager }\end{array}$ & Automatic & $\begin{array}{l}\text { Authenticated Users: Read - } \\
\text { CR } \\
\text { Administrators: Full Control } \\
\text { Power Users: Read - CR } \\
\text { INTERACTIVE: Read - CR - } \\
\text { RC + Start } \\
\text { Users: Read - CR - RC + Start }\end{array}$ & Everyone: Fail, Full Control \\
\hline Server & Automatic & $\begin{array}{l}\text { Authenticated Users: Read } \\
\text { Power Users: Read + Start } \\
\text { Administrators: Full Control } \\
\text { Server Operators: Full Control } \\
\text { SYSTEM: Read + Start + Stop } \\
\text { + Pause } \\
\end{array}$ & Everyone: Fail, Full Control \\
\hline SMTPSVC & Automatic & $\begin{array}{l}\text { Authenticated Users: Read } \\
\text { Power Users: Read + Start } \\
\text { Administrators: Full Control } \\
\text { Server Operators: Full Control } \\
\text { SYSTEM: Read + Start + Stop } \\
\text { + Pause }\end{array}$ & Everyone: Fail, Full Control \\
\hline $\begin{array}{l}\text { System Event } \\
\text { Notification }\end{array}$ & Automatic & $\begin{array}{l}\text { Authenticated Users: Read } \\
\text { Power Users: Read + Start } \\
\text { Administrators: Full Control } \\
\text { Server Operators: Full Control } \\
\text { SYSTEM: Read + Start + Stop } \\
\text { + Pause }\end{array}$ & Everyone: Fail, Full Control \\
\hline $\begin{array}{l}\text { Task } \\
\text { Scheduler }\end{array}$ & Automatic & $\begin{array}{l}\text { Authenticated Users: Read } \\
\text { Power Users: Read + Start } \\
\text { Administrators: Full Control } \\
\text { Server Operators: Full Control } \\
\text { SYSTEM: Read + Start + Stop }\end{array}$ & Everyone: Fail, Full Control \\
\hline
\end{tabular}




\begin{tabular}{|c|c|c|c|}
\hline & & + Pause & \\
\hline $\begin{array}{l}\text { TCP/IP } \\
\text { NetBIOS } \\
\text { Helper Service }\end{array}$ & Automatic & $\begin{array}{l}\text { Authenticated Users: Read } \\
\text { Power Users: Read + Start } \\
\text { Administrators: Full Control } \\
\text { Server Operators: Full Control } \\
\text { SYSTEM: Read + Start + Stop } \\
\text { + Pause }\end{array}$ & Everyone: Fail, Full Control \\
\hline $\begin{array}{l}\text { Windows } \\
\text { Time }\end{array}$ & Automatic & $\begin{array}{l}\text { Authenticated Users: Read - } \\
\text { CR } \\
\text { Administrators: Full Control } \\
\text { Power Users: Read - CR } \\
\text { Server Operators: Full Control } \\
\text { INTERACTIVE: Read - CR - } \\
\text { RC + Start } \\
\text { Users: Read - CR - RC + Start }\end{array}$ & Everyone: Fail, Full Control \\
\hline Workstation & Automatic & $\begin{array}{l}\text { Authenticated Users: Read } \\
\text { Power Users: Read + Start } \\
\text { Administrators: Full Control } \\
\text { Server Operators: Full Control } \\
\text { SYSTEM: Read + Start + Stop } \\
\text { + Pause }\end{array}$ & Everyone: Fail, Full Control \\
\hline
\end{tabular}

\section{REGISTRY}

The registry area allows you to set permissions and auditing on registry keys in the HKEY_LOCAL_MACHINE (machine) and HKEY_USERS (user) hives of the system registry. The actual permission settings are somewhat complicated so you will have to examine the Setup Security template with the Security Templates console to see them.

\begin{tabular}{|c|c|c|}
\hline (Object Name & Workstaions Permissions & Server Permissions \\
\hline machinelsoftware & $\begin{array}{l}\text { Users: Read (key and } \\
\text { subkeys) } \\
\text { Power Users: Read, Write, } \\
\text { and Delete (key and } \\
\text { subkeys) } \\
\text { Administrators: Full } \\
\text { Control (key and subkeys) } \\
\text { SYSTEM: Full Control } \\
\text { (key and subkeys) } \\
\text { CREATOR OWNER: } \\
\text { Full Control (key and } \\
\text { subkeys) }\end{array}$ & $\begin{array}{l}\text { Users: Read (key and } \\
\text { subkeys) } \\
\text { Power Users: Read, Write, } \\
\text { and Delete (key and } \\
\text { subkeys) } \\
\text { Administrators: Full } \\
\text { Control (key and subkeys) } \\
\text { SYSTEM: Full Control } \\
\text { (key and subkeys) } \\
\text { CREATOR OWNER: } \\
\text { Full Control (key and } \\
\text { subkeys) } \\
\text { Terminal Services User: } \\
\text { Read, Write, and Delete } \\
\text { (key and subkeys) }\end{array}$ \\
\hline
\end{tabular}




\begin{tabular}{|c|c|c|}
\hline machinelsoftwarelclasses & $\begin{array}{l}\text { Users: Read (key and } \\
\text { subkeys) } \\
\text { Power Users: Read, Write, } \\
\text { and Delete (key and } \\
\text { subkeys) } \\
\text { Administrators: Full } \\
\text { Control (key and subkeys) } \\
\text { SYSTEM: Full Control } \\
\text { (key and subkeys) } \\
\text { CREATOR OWNER: } \\
\text { Full Control (key and } \\
\text { subkeys) } \\
\text { Authenticated Users: } \\
\text { Read (key and subkeys) }\end{array}$ & $\begin{array}{l}\text { Users: Read (key and } \\
\text { subkeys) } \\
\text { Power Users: Read, Write, } \\
\text { and Delete (key and } \\
\text { subkeys) } \\
\text { Administrators: Full } \\
\text { Control (key and subkeys) } \\
\text { SYSTEM: Full Control } \\
\text { (key and subkeys) } \\
\text { CREATOR OWNER: } \\
\text { Full Control (key and } \\
\text { subkeys) } \\
\text { Terminal Services User: } \\
\text { Read, Write, and Delete } \\
\text { (key and subkeys) } \\
\text { Authenticated Users: } \\
\text { Read (key and subkeys) }\end{array}$ \\
\hline 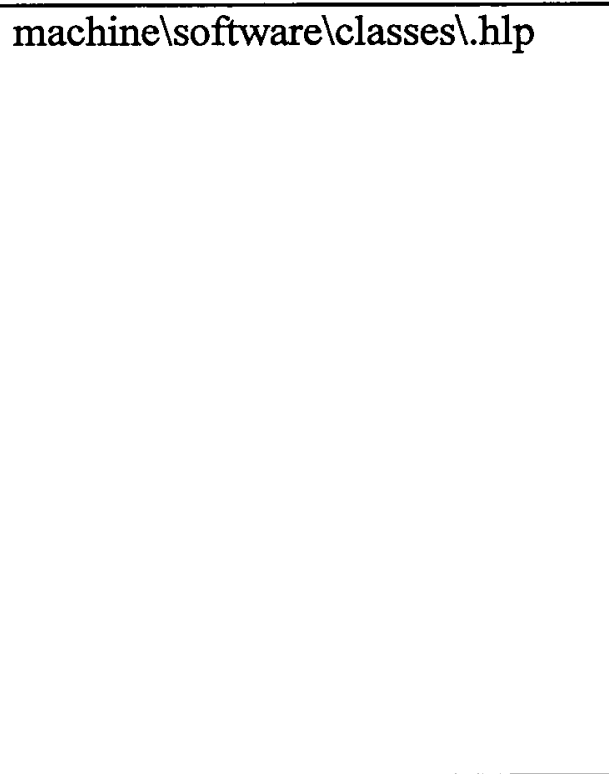 & $\begin{array}{l}\text { Users: Read (key and } \\
\text { subkeys) } \\
\text { Power Users: Read (key } \\
\text { and subkeys) } \\
\text { Administrators: Full } \\
\text { Control (key and subkeys) } \\
\text { SYSTEM: Full Control } \\
\text { (key and subkeys) } \\
\text { CREATOR OWNER: } \\
\text { Full Control (key and } \\
\text { subkeys) } \\
\text { Authenticated Users: } \\
\text { Read (key and subkeys) }\end{array}$ & $\begin{array}{l}\text { Users: Read (key and } \\
\text { subkeys) } \\
\text { Power Users: Read (key } \\
\text { and subkeys) } \\
\text { Administrators: Full } \\
\text { Control (key and subkeys) } \\
\text { SYSTEM: Full Control } \\
\text { (key and subkeys) } \\
\text { CREATOR OWNER: } \\
\text { Full Control (key and } \\
\text { subkeys) } \\
\text { Terminal Services User: } \\
\text { Read, Write, and Delete } \\
\text { (key and subkeys) } \\
\text { Authenticated Users: } \\
\text { Read (key and subkeys) }\end{array}$ \\
\hline machinelsoftwarelclassesthelpfile & $\begin{array}{l}\text { Users: Read (key and } \\
\text { subkeys) } \\
\text { Power Users: Read (key } \\
\text { and subkeys) } \\
\text { Administrators: Full } \\
\text { Control (key and subkeys) } \\
\text { SYSTEM: Full Control } \\
\text { (key and subkeys) } \\
\text { CREATOR OWNER: } \\
\text { Full Control (key and } \\
\text { subkeys) } \\
\text { Authenticated Users: } \\
\text { Read (key and subkeys) }\end{array}$ & $\begin{array}{l}\text { Users: Read (key and } \\
\text { subkeys) } \\
\text { Power Users: Read (key } \\
\text { and subkeys) } \\
\text { Administrators: Full } \\
\text { Control (key and subkeys) } \\
\text { SYSTEM: Full Control } \\
\text { (key and subkeys) } \\
\text { CREATOR OWNER: } \\
\text { Full Control (key and } \\
\text { subkeys) } \\
\text { Terminal Services User: } \\
\text { Read, Write, and Delete }\end{array}$ \\
\hline
\end{tabular}




\begin{tabular}{|c|c|c|}
\hline & & $\begin{array}{l}\text { (key and subkeys) } \\
\text { Authenticated Users: } \\
\text { Read (key and subkeys) }\end{array}$ \\
\hline $\begin{array}{l}\text { machinelsoftwarelmicrosoftlcomma } \\
\text { nd processor }\end{array}$ & $\begin{array}{l}\text { Users: Read (key and } \\
\text { subkeys) } \\
\text { Power Users: Read (key } \\
\text { and subkeys) } \\
\text { Administrators: Full } \\
\text { Control (key and subkeys) } \\
\text { SYSTEM: Full Control } \\
\text { (key and subkeys) } \\
\text { CREATOR OWNER: } \\
\text { Full Control (key and } \\
\text { subkeys) }\end{array}$ & $\begin{array}{l}\text { Users: Read (key and } \\
\text { subkeys) } \\
\text { Power Users: Read (key } \\
\text { and subkeys) } \\
\text { Administrators: Full } \\
\text { Control (key and subkeys) } \\
\text { SYSTEM: Full Control } \\
\text { (key and subkeys) } \\
\text { CREATOR OWNER: } \\
\text { Full Control (key and } \\
\text { subkeys) }\end{array}$ \\
\hline $\begin{array}{l}\text { machinelsoftwarelmicrosoft } \mid \\
\text { cryptography }\end{array}$ & $\begin{array}{l}\text { Users: Read (key and } \\
\text { subkeys) } \\
\text { Power Users: Read (key } \\
\text { and subkeys) } \\
\text { Administrators: Full } \\
\text { Control (key and subkeys) } \\
\text { SYSTEM: Full Control } \\
\text { (key and subkeys) } \\
\text { CREATOR OWNER: } \\
\text { Full Control (key and } \\
\text { subkeys) }\end{array}$ & $\begin{array}{l}\text { Users: Read (key and } \\
\text { subkeys) } \\
\text { Power Users: Read (key } \\
\text { and subkeys) } \\
\text { Administrators: Full } \\
\text { Control (key and subkeys) } \\
\text { SYSTEM: Full Control } \\
\text { (key and subkeys) } \\
\text { CREATOR OWNER: } \\
\text { Full Control (key and } \\
\text { subkeys) }\end{array}$ \\
\hline $\begin{array}{l}\text { machinelsoftwarelmicrosoft } \\
\text { cryptographyloid }\end{array}$ & & $\begin{array}{l}\text { Users: Read (key and } \\
\text { subkeys) } \\
\text { Power Users: Read (key } \\
\text { and subkeys) } \\
\text { Administrators: Full } \\
\text { Control (key and subkeys) } \\
\text { SYSTEM: Full Control } \\
\text { (key and subkeys) } \\
\text { CREATOR OWNER: } \\
\text { Full Control (key and } \\
\text { subkeys) }\end{array}$ \\
\hline $\begin{array}{l}\text { machinelsoftwarelmicrosoft } \\
\text { cryptography/providersitrust }\end{array}$ & & $\begin{array}{l}\text { Users: Read (key and } \\
\text { subkeys) } \\
\text { Power Users: Read (key } \\
\text { and subkeys) } \\
\text { Administrators: Full } \\
\text { Control (key and subkeys) } \\
\text { SYSTEM: Full Control } \\
\text { (key and subkeys) } \\
\text { CREATOR OWNER: } \\
\text { Full Control (key and }\end{array}$ \\
\hline
\end{tabular}




\begin{tabular}{|c|c|c|}
\hline & & subkeys) \\
\hline $\begin{array}{l}\text { machinelsoftwarelmicrosoft } \\
\text { cryptographylservices }\end{array}$ & & $\begin{array}{l}\text { Users: Read (key and } \\
\text { subkeys) } \\
\text { Power Users: Read (key } \\
\text { and subkeys) } \\
\text { Administrators: Full } \\
\text { Control (key and subkeys) } \\
\text { SYSTEM: Full Control } \\
\text { (key and subkeys) } \\
\text { CREATOR OWNER: } \\
\text { Full Control (key and } \\
\text { subkeys) }\end{array}$ \\
\hline $\begin{array}{l}\text { machinelsoftwarelmicrosoftldriver } \\
\text { signing }\end{array}$ & $\begin{array}{l}\text { Users: Read (key and } \\
\text { subkeys) } \\
\text { Power Users: Read (key } \\
\text { and subkeys) } \\
\text { Administrators: Full } \\
\text { Control (key and subkeys) } \\
\text { SYSTEM: Full Control } \\
\text { (key and subkeys) } \\
\text { CREATOR OWNER: } \\
\text { Full Control (key and } \\
\text { subkeys) }\end{array}$ & $\begin{array}{l}\text { Users: Read (key and } \\
\text { subkeys) } \\
\text { Power Users: Read (key } \\
\text { and subkeys) } \\
\text { Administrators: Full } \\
\text { Control (key and subkeys) } \\
\text { SYSTEM: Full Control } \\
\text { (key and subkeys) } \\
\text { CREATOR OWNER: } \\
\text { Full Control (key and } \\
\text { subkeys) }\end{array}$ \\
\hline $\begin{array}{l}\text { machine } \backslash \text { software } \backslash \text { microsoft } \backslash \\
\text { enterprisecertificates }\end{array}$ & $\begin{array}{l}\text { Users: Read (key and } \\
\text { subkeys) } \\
\text { Power Users: Read (key } \\
\text { and subkeys) } \\
\text { Administrators: Full } \\
\text { Control (key and subkeys) } \\
\text { SYSTEM: Full Control } \\
\text { (key and subkeys) } \\
\text { CREATOR OWNER: } \\
\text { Full Control (key and } \\
\text { subkeys) }\end{array}$ & $\begin{array}{l}\text { Users: Read (key and } \\
\text { subkeys) } \\
\text { Power Users: Read (key } \\
\text { and subkeys) } \\
\text { Administrators: Full } \\
\text { Control (key and subkeys) } \\
\text { SYSTEM: Full Control } \\
\text { (key and subkeys) } \\
\text { CREATOR OWNER: } \\
\text { Full Control (key and } \\
\text { subkeys) }\end{array}$ \\
\hline machinelsoftwarelmicrosoftlnetdde & $\begin{array}{l}\text { Administrators: Full } \\
\text { Control (key and subkeys) } \\
\text { SYSTEM: Full Control } \\
\text { (key and subkeys) } \\
\text { CREATOR OWNER: } \\
\text { Full Control (key and } \\
\text { subkeys) }\end{array}$ & $\begin{array}{l}\text { Administrators: Full } \\
\text { Control (key and subkeys) } \\
\text { SYSTEM: Full Control } \\
\text { (key and subkeys) } \\
\text { CREATOR OWNER: } \\
\text { Full Control (key and } \\
\text { subkeys) }\end{array}$ \\
\hline $\begin{array}{l}\text { machine } \backslash \text { software } \backslash \text { microsoft } \backslash \text { non- } \\
\text { driver signing }\end{array}$ & $\begin{array}{l}\text { Users: Read (key and } \\
\text { subkeys) } \\
\text { Power Users: Read (key } \\
\text { and subkeys) } \\
\text { Administrators: Full }\end{array}$ & $\begin{array}{l}\text { Users: Read (key and } \\
\text { subkeys) } \\
\text { Power Users: Read (key } \\
\text { and subkeys) } \\
\text { Administrators: Full }\end{array}$ \\
\hline
\end{tabular}




\begin{tabular}{|c|c|c|}
\hline & $\begin{array}{l}\text { Control (key and subkeys) } \\
\text { SYSTEM: Full Control } \\
\text { (key and subkeys) } \\
\text { CREATOR OWNER: } \\
\text { Full Control (key and } \\
\text { subkeys) }\end{array}$ & $\begin{array}{l}\text { Control (key and subkeys) } \\
\text { SYSTEM: Full Control } \\
\text { (key and subkeys) } \\
\text { CREATOR OWNER: } \\
\text { Full Control (key and } \\
\text { subkeys) }\end{array}$ \\
\hline machinelsoftwarelmicrosoftlole & $\begin{array}{l}\text { Users: Read (key and } \\
\text { subkeys) } \\
\text { Power Users: Read (key } \\
\text { and subkeys) } \\
\text { Administrators: Full } \\
\text { Control (key and subkeys) } \\
\text { SYSTEM: Full Control } \\
\text { (key and subkeys) } \\
\text { CREATOR OWNER: } \\
\text { Full Control (key and } \\
\text { subkeys) }\end{array}$ & $\begin{array}{l}\text { Users: Read (key and } \\
\text { subkeys) } \\
\text { Power Users: Read (key } \\
\text { and subkeys) } \\
\text { Administrators: Full } \\
\text { Control (key and subkeys) } \\
\text { SYSTEM: Full Control } \\
\text { (key and subkeys) } \\
\text { CREATOR OWNER: } \\
\text { Full Control (key and } \\
\text { subkeys) }\end{array}$ \\
\hline $\begin{array}{l}\text { machinelsoftware } \mid \text { microsoft } \backslash \\
\text { protected storage system provider }\end{array}$ & Inherit from parent & Inherit from parent \\
\hline machinelsoftwarelmicrosoftlrpc & $\begin{array}{l}\text { Users: Read (key and } \\
\text { subkeys) } \\
\text { Power Users: Read (key } \\
\text { and subkeys) } \\
\text { Administrators: Full } \\
\text { Control (key and subkeys) } \\
\text { SYSTEM: Full Control } \\
\text { (key and subkeys) } \\
\text { CREATOR OWNER: } \\
\text { Full Control (key and } \\
\text { subkeys) }\end{array}$ & $\begin{array}{l}\text { Users: Read (key and } \\
\text { subkeys) } \\
\text { Power Users: Read (key } \\
\text { and subkeys) } \\
\text { Administrators: Full } \\
\text { Control (key and subkeys) } \\
\text { SYSTEM: Full Control } \\
\text { (key and subkeys) } \\
\text { CREATOR OWNER: } \\
\text { Full Control (key and } \\
\text { subkeys) }\end{array}$ \\
\hline machinelsoftwarelmicrosoft $\backslash$ secure & $\begin{array}{l}\text { Users: Read (key and } \\
\text { subkeys) } \\
\text { Power Users: Read (key } \\
\text { and subkeys) } \\
\text { Administrators: Full } \\
\text { Control (key and subkeys) } \\
\text { SYSTEM: Full Control } \\
\text { (key and subkeys) } \\
\text { CREATOR OWNER: } \\
\text { Full Control (key and } \\
\text { subkeys) }\end{array}$ & $\begin{array}{l}\text { Users: Read (key and } \\
\text { subkeys) } \\
\text { Power Users: Read (key } \\
\text { and subkeys) } \\
\text { Administrators: Full } \\
\text { Control (key and subkeys) } \\
\text { SYSTEM: Full Control } \\
\text { (key and subkeys) } \\
\text { CREATOR OWNER: } \\
\text { Full Control (key and } \\
\text { subkeys) }\end{array}$ \\
\hline $\begin{array}{l}\text { machinelsoftwarelmicrosoftlsystem } \\
\text { certificates }\end{array}$ & $\begin{array}{l}\text { Users: Read (key and } \\
\text { subkeys) } \\
\text { Power Users: Read (key } \\
\text { and subkeys) } \\
\text { Administrators: Full }\end{array}$ & $\begin{array}{l}\text { Users: Read (key and } \\
\text { subkeys) } \\
\text { Power Users: Read (key } \\
\text { and subkeys) } \\
\text { Administrators: Full }\end{array}$ \\
\hline
\end{tabular}




\begin{tabular}{|c|c|c|}
\hline & $\begin{array}{l}\text { Control (key and subkeys) } \\
\text { SYSTEM: Full Control } \\
\text { (key and subkeys) } \\
\text { CREATOR OWNER: } \\
\text { Full Control (key and } \\
\text { subkeys) }\end{array}$ & $\begin{array}{l}\text { Control (key and subkeys) } \\
\text { SYSTEM: Full Control } \\
\text { (key and subkeys) } \\
\text { CREATOR OWNER: } \\
\text { Full Control (key and } \\
\text { subkeys) }\end{array}$ \\
\hline $\begin{array}{l}\text { machinelsoftwarelmicrosoft } \\
\text { windows ntlcurrentversion }\end{array}$ & $\begin{array}{l}\text { Authenticated Users: } \\
\text { Read (key and subkeys) }\end{array}$ & $\begin{array}{l}\text { Authenticated Users: } \\
\text { Read (key and subkeys) }\end{array}$ \\
\hline $\begin{array}{l}\text { machinelsoftwarelmicrosoft } \\
\text { windows ntlcurrentversion } \backslash \\
\text { accessibility }\end{array}$ & $\begin{array}{l}\text { Users: Read (key and } \\
\text { subkeys) } \\
\text { Power Users: Read (key } \\
\text { and subkeys) } \\
\text { Administrators: Full } \\
\text { Control (key and subkeys) } \\
\text { SYSTEM: Full Control } \\
\text { (key and subkeys) } \\
\text { CREATOR OWNER: } \\
\text { Full Control (key and } \\
\text { subkeys) }\end{array}$ & $\begin{array}{l}\text { Users: Read (key and } \\
\text { subkeys) } \\
\text { Power Users: Read (key } \\
\text { and subkeys) } \\
\text { Administrators: Full } \\
\text { Control (key and subkeys) } \\
\text { SYSTEM: Full Control } \\
\text { (key and subkeys) } \\
\text { CREATOR OWNER: } \\
\text { Full Control (key and } \\
\text { subkeys) }\end{array}$ \\
\hline $\begin{array}{l}\text { machine } \backslash \text { software } \backslash \text { microsoft } \backslash \\
\text { windows ntlcurrentversion\laedebug }\end{array}$ & $\begin{array}{l}\text { Users: Read (key and } \\
\text { subkeys) } \\
\text { Power Users: Read (key } \\
\text { and subkeys) } \\
\text { Administrators: Full } \\
\text { Control (key and subkeys) } \\
\text { SYSTEM: Full Control } \\
\text { (key and subkeys) } \\
\text { CREATOR OWNER: } \\
\text { Full Control (key and } \\
\text { subkeys) }\end{array}$ & $\begin{array}{l}\text { Users: Read (key and } \\
\text { subkeys) } \\
\text { Power Users: Read (key } \\
\text { and subkeys) } \\
\text { Administrators: Full } \\
\text { Control (key and subkeys) } \\
\text { SYSTEM: Full Control } \\
\text { (key and subkeys) } \\
\text { CREATOR OWNER: } \\
\text { Full Control (key and } \\
\text { subkeys) }\end{array}$ \\
\hline $\begin{array}{l}\text { machinelsoftwarelmicrosoft } \backslash \\
\text { windows ntlcurrentversion } \backslash \\
\text { asrcommands }\end{array}$ & $\begin{array}{l}\text { Users: Read (key and } \\
\text { subkeys) } \\
\text { Power Users: Read (key } \\
\text { and subkeys) } \\
\text { Administrators: Full } \\
\text { Control (key and subkeys) } \\
\text { SYSTEM: Full Control } \\
\text { (key and subkeys) } \\
\text { CREATOR OWNER: } \\
\text { Full Control (key and } \\
\text { subkeys) } \\
\text { (A;CI;GRGWSD;;BO) }\end{array}$ & $\begin{array}{l}\text { Users: Read (key and } \\
\text { subkeys) } \\
\text { Power Users: Read (key } \\
\text { and subkeys) } \\
\text { Administrators: Full } \\
\text { Control (key and subkeys) } \\
\text { SYSTEM: Full Control } \\
\text { (key and subkeys) } \\
\text { CREATOR OWNER: } \\
\text { Full Control (key and } \\
\text { subkeys) }\end{array}$ \\
\hline $\begin{array}{l}\text { machinelsoftwarelmicrosoft } \\
\text { windows ntlcurrentversionlclasses }\end{array}$ & $\begin{array}{l}\text { Users: Read (key and } \\
\text { subkeys) } \\
\text { Power Users: Read (key } \\
\text { and subkeys) }\end{array}$ & $\begin{array}{l}\text { Users: Read (key and } \\
\text { subkeys) } \\
\text { Power Users: Read (key } \\
\text { and subkeys) }\end{array}$ \\
\hline
\end{tabular}




\begin{tabular}{|c|c|c|}
\hline & $\begin{array}{l}\text { Administrators: Full } \\
\text { Control (key and subkeys) } \\
\text { SYSTEM: Full Control } \\
\text { (key and subkeys) } \\
\text { CREATOR OWNER: } \\
\text { Full Control (key and } \\
\text { subkeys) }\end{array}$ & $\begin{array}{l}\text { Administrators: Full } \\
\text { Control (key and subkeys) } \\
\text { SYSTEM: Full Control } \\
\text { (key and subkeys) } \\
\text { CREATOR OWNER: } \\
\text { Full Control (key and } \\
\text { subkeys) }\end{array}$ \\
\hline $\begin{array}{l}\text { machinelsoftwarelmicrosoft| } \\
\text { windows nt|currentversionl } \\
\text { drivers32 }\end{array}$ & $\begin{array}{l}\text { Users: Read (key and } \\
\text { subkeys) } \\
\text { Power Users: Read (key } \\
\text { and subkeys) } \\
\text { Administrators: Full } \\
\text { Control (key and subkeys) } \\
\text { SYSTEM: Full Control } \\
\text { (key and subkeys) } \\
\text { CREATOR OWNER: } \\
\text { Full Control (key and } \\
\text { subkeys) }\end{array}$ & $\begin{array}{l}\text { Users: Read (key and } \\
\text { subkeys) } \\
\text { Power Users: Read (key } \\
\text { and subkeys) } \\
\text { Administrators: Full } \\
\text { Control (key and subkeys) } \\
\text { SYSTEM: Full Control } \\
\text { (key and subkeys) } \\
\text { CREATOR OWNER: } \\
\text { Full Control (key and } \\
\text { subkeys) }\end{array}$ \\
\hline $\begin{array}{l}\text { machine } \mid \text { softwarelmicrosoft } \backslash \\
\text { windows ntlcurrentversionlefs }\end{array}$ & $\begin{array}{l}\text { Users: Read (key and } \\
\text { subkeys) } \\
\text { Power Users: Read (key } \\
\text { and subkeys) } \\
\text { Administrators: Full } \\
\text { Control (key and subkeys) } \\
\text { SYSTEM: Full Control } \\
\text { (key and subkeys) } \\
\text { CREATOR OWNER: } \\
\text { Full Control (key and } \\
\text { subkeys) }\end{array}$ & $\begin{array}{l}\text { Users: Read (key and } \\
\text { subkeys) } \\
\text { Power Users: Read (key } \\
\text { and subkeys) } \\
\text { Administrators: Full } \\
\text { Control (key and subkeys) } \\
\text { SYSTEM: Full Control } \\
\text { (key and subkeys) } \\
\text { CREATOR OWNER: } \\
\text { Full Control (key and } \\
\text { subkeys) }\end{array}$ \\
\hline $\begin{array}{l}\text { machinelsoftwarelmicrosoft } \mid \\
\text { windows ntlcurrentversionlfont } \\
\text { drivers }\end{array}$ & $\begin{array}{l}\text { Users: Read (key and } \\
\text { subkeys) } \\
\text { Power Users: Read (key } \\
\text { and subkeys) } \\
\text { Administrators: Full } \\
\text { Control (key and subkeys) } \\
\text { SYSTEM: Full Control } \\
\text { (key and subkeys) } \\
\text { CREATOR OWNER: } \\
\text { Full Control (key and } \\
\text { subkeys) }\end{array}$ & $\begin{array}{l}\text { Users: Read (key and } \\
\text { subkeys) } \\
\text { Power Users: Read (key } \\
\text { and subkeys) } \\
\text { Administrators: Full } \\
\text { Control (key and subkeys) } \\
\text { SYSTEM: Full Control } \\
\text { (key and subkeys) } \\
\text { CREATOR OWNER: } \\
\text { Full Control (key and } \\
\text { subkeys) }\end{array}$ \\
\hline \begin{tabular}{l} 
machinelsoftwarelmicrosoft। \\
windows ntlcurrentversion\} $\\
{\text { fontmapper }}$ & $\begin{array}{l}\text { Users: Read (key and } \\
\text { subkeys) } \\
\text { Power Users: Read (key } \\
\text { and subkeys) } \\
\text { Administrators: Full } \\
\text { Control (key and subkeys) }\end{array}$ & $\begin{array}{l}\text { Users: Read (key and } \\
\text { subkeys) } \\
\text { Power Users: Read (key } \\
\text { and subkeys) } \\
\text { Administrators: Full } \\
\text { Control (key and subkeys) }\end{array}$ \\
\hline
\end{tabular}
\end{tabular}




\begin{tabular}{|c|c|c|}
\hline & $\begin{array}{l}\text { SYSTEM: Full Control } \\
\text { (key and subkeys) } \\
\text { CREATOR OWNER: } \\
\text { Full Control (key and } \\
\text { subkeys) }\end{array}$ & $\begin{array}{l}\text { SYSTEM: Full Control } \\
\text { (key and subkeys) } \\
\text { CREATOR OWNER: } \\
\text { Full Control (key and } \\
\text { subkeys) }\end{array}$ \\
\hline $\begin{array}{l}\text { machinelsoftwarelmicrosoft } \mid \\
\text { windows ntlcurrentversionlimage } \\
\text { file execution options }\end{array}$ & $\begin{array}{l}\text { Users: Read (key and } \\
\text { subkeys) } \\
\text { Power Users: Read (key } \\
\text { and subkeys) } \\
\text { Administrators: Full } \\
\text { Control (key and subkeys) } \\
\text { SYSTEM: Full Control } \\
\text { (key and subkeys) } \\
\text { CREATOR OWNER: } \\
\text { Full Control (key and } \\
\text { subkeys) }\end{array}$ & $\begin{array}{l}\text { Users: Read (key and } \\
\text { subkeys) } \\
\text { Power Users: Read (key } \\
\text { and subkeys) } \\
\text { Administrators: Full } \\
\text { Control (key and subkeys) } \\
\text { SYSTEM: Full Control } \\
\text { (key and subkeys) } \\
\text { CREATOR OWNER: } \\
\text { Full Control (key and } \\
\text { subkeys) }\end{array}$ \\
\hline 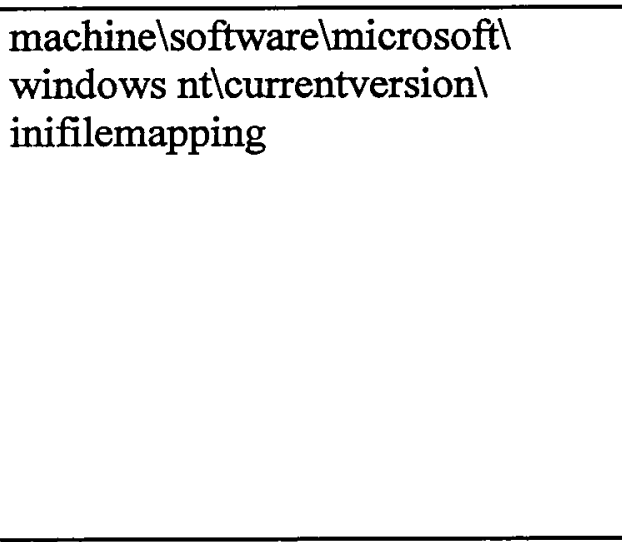 & $\begin{array}{l}\text { Users: Read (key and } \\
\text { subkeys) } \\
\text { Power Users: Read (key } \\
\text { and subkeys) } \\
\text { Administrators: Full } \\
\text { Control (key and subkeys) } \\
\text { SYSTEM: Full Control } \\
\text { (key and subkeys) } \\
\text { CREATOR OWNER: } \\
\text { Full Control (key and } \\
\text { subkeys) }\end{array}$ & $\begin{array}{l}\text { Users: Read (key and } \\
\text { subkeys) } \\
\text { Power Users: Read (key } \\
\text { and subkeys) } \\
\text { Administrators: Full } \\
\text { Control (key and subkeys) } \\
\text { SYSTEM: Full Control } \\
\text { (key and subkeys) } \\
\text { CREATOR OWNER: } \\
\text { Full Control (key and } \\
\text { subkeys) }\end{array}$ \\
\hline $\begin{array}{l}\text { machinelsoftwarelmicrosoft } \backslash \\
\text { windows ntlcurrentversionไperflib }\end{array}$ & $\begin{array}{l}\text { (A;CI;GR;;;IU) } \\
\text { Administrators: Full } \\
\text { Control (key and subkeys) } \\
\text { SYSTEM: Full Control } \\
\text { (key and subkeys) } \\
\text { CREATOR OWNER: } \\
\text { Full Control (key and } \\
\text { subkeys) }\end{array}$ & $\begin{array}{l}\text { (A;CI;GR;;;IU) } \\
\text { Administrators: Full } \\
\text { Control (key and subkeys) } \\
\text { SYSTEM: Full Control } \\
\text { (key and subkeys) } \\
\text { CREATOR OWNER: } \\
\text { Full Control (key and } \\
\text { subkeys) } \\
\end{array}$ \\
\hline \begin{tabular}{l} 
machine $\mid$ softwarelmicrosoft $\backslash$ \\
windows ntlcurrentversion\} $\\
{\text { perflibl009 }}$ & Inherit from parent & Inherit from parent \\
\hline $\begin{array}{l}\text { machinelsoftwarelmicrosoft } \\
\text { windows ntlcurrentversion\ports }\end{array}$ & & $\begin{array}{l}\text { Users: Read (key and } \\
\text { subkeys) } \\
\text { Power Users: Read, Write, } \\
\text { and Delete (key and } \\
\text { subkeys) } \\
\text { Administrators: Full } \\
\text { Control (key and subkeys) } \\
\text { SYSTEM: Full Control }\end{array}$ \\
\hline
\end{tabular}
\end{tabular}




\begin{tabular}{|c|c|c|}
\hline & & $\begin{array}{l}\text { (key and subkeys) } \\
\text { CREATOR OWNER: } \\
\text { Full Control (key and } \\
\text { subkeys) }\end{array}$ \\
\hline $\begin{array}{l}\text { machinelsoftwarelmicrosoft } \\
\text { windows ntlcurrentversion } \backslash \\
\text { profilelist }\end{array}$ & $\begin{array}{l}\text { Users: Read (key and } \\
\text { subkeys) } \\
\text { Power Users: Read (key } \\
\text { and subkeys) } \\
\text { Administrators: Full } \\
\text { Control (key and subkeys) } \\
\text { SYSTEM: Full Control } \\
\text { (key and subkeys) } \\
\text { CREATOR OWNER: } \\
\text { Full Control (key and } \\
\text { subkeys) }\end{array}$ & $\begin{array}{l}\text { Users: Read (key and } \\
\text { subkeys) } \\
\text { Power Users: Read (key } \\
\text { and subkeys) } \\
\text { Administrators: Full } \\
\text { Control (key and subkeys) } \\
\text { SYSTEM: Full Control } \\
\text { (key and subkeys) } \\
\text { CREATOR OWNER: } \\
\text { Full Control (key and } \\
\text { subkeys) }\end{array}$ \\
\hline $\begin{array}{l}\text { machinelsoftwarelmicrosoft } \mid \\
\text { windows ntlcurrentversionlsecedit }\end{array}$ & $\begin{array}{l}\text { Users: Read (key and } \\
\text { subkeys) } \\
\text { Power Users: Read (key } \\
\text { and subkeys) } \\
\text { Administrators: Full } \\
\text { Control (key and subkeys) } \\
\text { SYSTEM: Full Control } \\
\text { (key and subkeys) } \\
\text { CREATOR OWNER: } \\
\text { Full Control (key and } \\
\text { subkeys) }\end{array}$ & $\begin{array}{l}\text { Users: Read (key and } \\
\text { subkeys) } \\
\text { Power Users: Read (key } \\
\text { and subkeys) } \\
\text { Administrators: Full } \\
\text { Control (key and subkeys) } \\
\text { SYSTEM: Full Control } \\
\text { (key and subkeys) } \\
\text { CREATOR OWNER: } \\
\text { Full Control (key and } \\
\text { subkeys) }\end{array}$ \\
\hline $\begin{array}{l}\text { machine } \backslash \text { software } \backslash \text { microsoft } \backslash \\
\text { windows ntlcurrentversion } \backslash \text { setup } \backslash \\
\text { recoveryconsole }\end{array}$ & $\begin{array}{l}\text { Users: Read (key and } \\
\text { subkeys) } \\
\text { Power Users: Read (key } \\
\text { and subkeys) } \\
\text { Administrators: Fuli } \\
\text { Control (key and subkeys) } \\
\text { SYSTEM: Full Control } \\
\text { (key and subkeys) } \\
\text { CREATOR OWNER: } \\
\text { Full Control (key and } \\
\text { subkeys) }\end{array}$ & $\begin{array}{l}\text { Users: Read (key and } \\
\text { subkeys) } \\
\text { Power Users: Read (key } \\
\text { and subkeys) } \\
\text { Administrators: Full } \\
\text { Control (key and subkeys) } \\
\text { SYSTEM: Full Control } \\
\text { (key and subkeys) } \\
\text { CREATOR OWNER: } \\
\text { Full Control (key and } \\
\text { subkeys) }\end{array}$ \\
\hline $\begin{array}{l}\text { machinelsoftwarelmicrosoft } \mid \\
\text { windows ntlcurrentversionlsvchost }\end{array}$ & $\begin{array}{l}\text { Users: Read (key and } \\
\text { subkeys) } \\
\text { Power Users: Read (key } \\
\text { and subkeys) } \\
\text { Administrators: Full } \\
\text { Control (key and subkeys) } \\
\text { SYSTEM: Full Control } \\
\text { (key and subkeys) } \\
\text { CREATOR OWNER: }\end{array}$ & $\begin{array}{l}\text { Users: Read (key and } \\
\text { subkeys) } \\
\text { Power Users: Read (key } \\
\text { and subkeys) } \\
\text { Administrators: Full } \\
\text { Control (key and subkeys) } \\
\text { SYSTEM: Full Control } \\
\text { (key and subkeys) } \\
\text { CREATOR OWNER: }\end{array}$ \\
\hline
\end{tabular}




\begin{tabular}{|c|c|c|}
\hline & $\begin{array}{l}\text { Full Control (key and } \\
\text { subkeys) }\end{array}$ & $\begin{array}{l}\text { Full Control (key and } \\
\text { subkeys) }\end{array}$ \\
\hline $\begin{array}{l}\text { machinelsoftwarelmicrosoft } \backslash \\
\text { windows ntlcurrentversionltime } \\
\text { zones }\end{array}$ & $\begin{array}{l}\text { Users: Read (key and } \\
\text { subkeys) } \\
\text { Power Users: Read (key } \\
\text { and subkeys) } \\
\text { Administrators: Full } \\
\text { Control (key and subkeys) } \\
\text { SYSTEM: Full Control } \\
\text { (key and subkeys) } \\
\text { CREATOR OWNER: } \\
\text { Full Control (key and } \\
\text { subkeys) }\end{array}$ & $\begin{array}{l}\text { Users: Read (key and } \\
\text { subkeys) } \\
\text { Power Users: Read (key } \\
\text { and subkeys) } \\
\text { Administrators: Full } \\
\text { Control (key and subkeys) } \\
\text { SYSTEM: Full Control } \\
\text { (key and subkeys) } \\
\text { CREATOR OWNER: } \\
\text { Full Control (key and } \\
\text { subkeys) }\end{array}$ \\
\hline 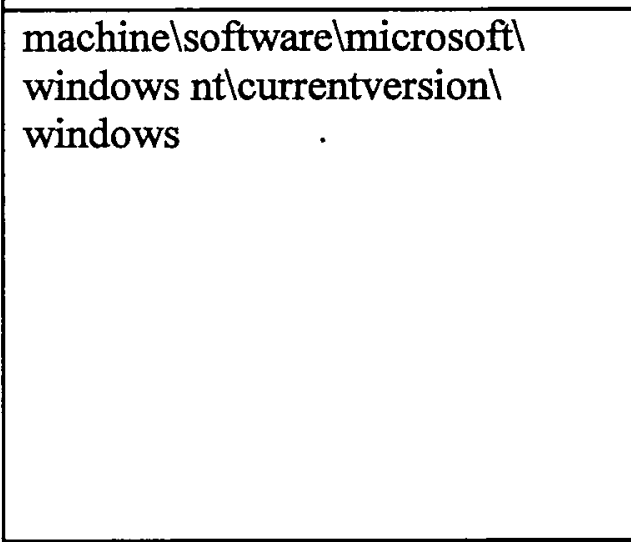 & $\begin{array}{l}\text { Users: Read (key and } \\
\text { subkeys) } \\
\text { Power Users: Read (key } \\
\text { and subkeys) } \\
\text { Administrators: Full } \\
\text { Control (key and subkeys) } \\
\text { SYSTEM: Full Control } \\
\text { (key and subkeys) } \\
\text { CREATOR OWNER: } \\
\text { Full Control (key and } \\
\text { subkeys) }\end{array}$ & $\begin{array}{l}\text { Users: Read (key and } \\
\text { subkeys) } \\
\text { Power Users: Read (key } \\
\text { and subkeys) } \\
\text { Administrators: Full } \\
\text { Control (key and subkeys) } \\
\text { SYSTEM: Full Control } \\
\text { (key and subkeys) } \\
\text { CREATOR OWNER: } \\
\text { Full Control (key and } \\
\text { subkeys) }\end{array}$ \\
\hline $\begin{array}{l}\text { machinelsoftwarelmicrosoft| } \\
\text { windowslcurrentversion }\end{array}$ & & $\begin{array}{l}\text { Users: Read (key and } \\
\text { subkeys) } \\
\text { Power Users: Read, Write, } \\
\text { and Delete (key and } \\
\text { subkeys) } \\
\text { Administrators: Full } \\
\text { Control (key and subkeys) } \\
\text { SYSTEM: Full Control } \\
\text { (key and subkeys) } \\
\text { CREATOR OWNER: } \\
\text { Full Control (key and } \\
\text { subkeys) }\end{array}$ \\
\hline $\begin{array}{l}\text { machinelsoftware \microsoft } \\
\text { windowslcurrentversionlgroup } \\
\text { policy }\end{array}$ & Inherit from parent & Inherit from parent \\
\hline $\begin{array}{l}\text { machinelsoftwarelmicrosoft| } \\
\text { windowslcurrentversionlinstaller }\end{array}$ & Inherit from parent & Inherit from parent \\
\hline $\begin{array}{l}\text { machinelsoftwarelmicrosoft } \mid \\
\text { windowslcurrentversionlpolicies }\end{array}$ & Inherit from parent & Inherit from parent \\
\hline $\begin{array}{l}\text { machinelsoftwarelmicrosoft } \backslash \\
\text { windowslcurrentversionlexplorer } \\
\text { user shell folders }\end{array}$ & $\begin{array}{l}\text { Users: Read (key and } \\
\text { subkeys) } \\
\text { Power Users: Read (key }\end{array}$ & $\begin{array}{l}\text { Users: Read (key and } \\
\text { subkeys) } \\
\text { Power Users: Read (key }\end{array}$ \\
\hline
\end{tabular}




\begin{tabular}{|c|c|c|}
\hline & $\begin{array}{l}\text { and subkeys) } \\
\text { Administrators: Full } \\
\text { Control (key and subkeys) } \\
\text { SYSTEM: Full Control } \\
\text { (key and subkeys) } \\
\text { CREATOR OWNER: } \\
\text { Full Control (key and } \\
\text { subkeys) }\end{array}$ & $\begin{array}{l}\text { and subkeys) } \\
\text { Administrators: Full } \\
\text { Control (key and subkeys) } \\
\text { SYSTEM: Full Control } \\
\text { (key and subkeys) } \\
\text { CREATOR OWNER: } \\
\text { Full Control (key and } \\
\text { subkeys) }\end{array}$ \\
\hline $\begin{array}{l}\text { machinelsoftware } \backslash \text { microsoft } \backslash \\
\text { windows } \backslash \text { currentversionlrunonce }\end{array}$ & $\begin{array}{l}\text { Users: Read (key and } \\
\text { subkeys) } \\
\text { Power Users: Read (key } \\
\text { and subkeys) } \\
\text { Administrators: Full } \\
\text { Control (key and subkeys) } \\
\text { SYSTEM: Full Control } \\
\text { (key and subkeys) } \\
\text { CREATOR OWNER: } \\
\text { Full Control (key and } \\
\text { subkeys) }\end{array}$ & $\begin{array}{l}\text { Users: Read (key and } \\
\text { subkeys) } \\
\text { Power Users: Read (key } \\
\text { and subkeys) } \\
\text { Administrators: Full } \\
\text { Control (key and subkeys) } \\
\text { SYSTEM: Full Control } \\
\text { (key and subkeys) } \\
\text { CREATOR OWNER: } \\
\text { Full Control (key and } \\
\text { subkeys) }\end{array}$ \\
\hline $\begin{array}{l}\text { machinelsoftware } \backslash \text { microsoft } \backslash \\
\text { windows } \backslash \text { currentversion\runonceex }\end{array}$ & $\begin{array}{l}\text { Users: Read (key and } \\
\text { subkeys) } \\
\text { Power Users: Read (key } \\
\text { and subkeys) } \\
\text { Administrators: Full } \\
\text { Control (key and subkeys) } \\
\text { SYSTEM: Full Control } \\
\text { (key and subkeys) } \\
\text { CREATOR OWNER: } \\
\text { Full Control (key and } \\
\text { subkeys) }\end{array}$ & $\begin{array}{l}\text { Users: Read (key and } \\
\text { subkeys) } \\
\text { Power Users: Read (key } \\
\text { and subkeys) } \\
\text { Administrators: Full } \\
\text { Control (key and subkeys) } \\
\text { SYSTEM: Full Control } \\
\text { (key and subkeys) } \\
\text { CREATOR OWNER: } \\
\text { Full Control (key and } \\
\text { subkeys) }\end{array}$ \\
\hline $\begin{array}{l}\text { machinelsoftwarelmicrosoft } \backslash \\
\text { windows ntlcurrentversion } \backslash \\
\text { winlogon }\end{array}$ & $\begin{array}{l}\text { Users: Read (key and } \\
\text { subkeys) } \\
\text { Power Users: Read (key } \\
\text { and subkeys) } \\
\text { Administrators: Full } \\
\text { Control (key and subkeys) } \\
\text { SYSTEM: Full Control } \\
\text { (key and subkeys) } \\
\text { CREATOR OWNER: } \\
\text { Full Control (key and } \\
\text { subkeys) }\end{array}$ & $\begin{array}{l}\text { Users: Read (key and } \\
\text { subkeys) } \\
\text { Power Users: Read (key } \\
\text { and subkeys) } \\
\text { Administrators: Full } \\
\text { Control (key and subkeys) } \\
\text { SYSTEM: Full Control } \\
\text { (key and subkeys) } \\
\text { CREATOR OWNER: } \\
\text { Full Control (key and } \\
\text { subkeys) }\end{array}$ \\
\hline machinelsoftwarelpolicies & $\begin{array}{l}\text { Users: Read (key and } \\
\text { subkeys) } \\
\text { Power Users: Read (key } \\
\text { and subkeys) } \\
\text { Administrators: Full }\end{array}$ & $\begin{array}{l}\text { Users: Read (key and } \\
\text { subkeys) } \\
\text { Power Users: Read (key } \\
\text { and subkeys) } \\
\text { Administrators: Full }\end{array}$ \\
\hline
\end{tabular}




\begin{tabular}{|c|c|c|}
\hline & $\begin{array}{l}\text { Control (key and subkeys) } \\
\text { SYSTEM: Full Control } \\
\text { (key and subkeys) } \\
\text { CREATOR OWNER: } \\
\text { Full Control (key and } \\
\text { subkeys) }\end{array}$ & $\begin{array}{l}\text { Control (key and subkeys) } \\
\text { SYSTEM: Full Control } \\
\text { (key and subkeys) } \\
\text { CREATOR OWNER: } \\
\text { Full Control (key and } \\
\text { subkeys) }\end{array}$ \\
\hline machinelsystem & $\begin{array}{l}\text { Users: Read (key and } \\
\text { subkeys) } \\
\text { Power Users: Read (key } \\
\text { and subkeys) } \\
\text { Administrators: Full } \\
\text { Control (key and subkeys) } \\
\text { SYSTEM: Full Control } \\
\text { (key and subkeys) } \\
\text { CREATOR OWNER: } \\
\text { Full Control (key and } \\
\text { subkeys) }\end{array}$ & $\begin{array}{l}\text { Users: Read (key and } \\
\text { subkeys) } \\
\text { Power Users: Read (key } \\
\text { and subkeys) } \\
\text { Administrators: Full } \\
\text { Control (key and subkeys) } \\
\text { SYSTEM: Full Control } \\
\text { (key and subkeys) } \\
\text { CREATOR OWNER: } \\
\text { Full Control (key and } \\
\text { subkeys) }\end{array}$ \\
\hline machinelsystemlclone & Inherit from parent & Inherit from parent \\
\hline machinelsystemlcontrolset001 & Inherit from parent & Inherit from parent \\
\hline machinelsystemlcontrolset002 & Inherit from parent & Inherit from parent \\
\hline machinelsystemlcontrolset 003 & Inherit from parent & Inherit from parent \\
\hline machinelsystemlcontrolset004 & Inherit from parent & Inherit from parent \\
\hline machinelsystemlcontrolset005 & Inherit from parent & Inherit from parent \\
\hline machinelsystemlcontrolset006 & Inherit from parent & Inherit from parent \\
\hline machinelsystemlcontrolset007 & Inherit from parent & Inherit from parent \\
\hline machinelsystemlcontrolset008 & Inherit from parent & Inherit from parent \\
\hline machinelsystemlcontrolset009 & Inherit from parent & Inherit from parent \\
\hline machinelsystemlcontrolset 010 & Inherit from parent & Inherit from parent \\
\hline $\begin{array}{l}\text { machinelsystemlcurrentcontrolsetl } \\
\text { controllclass }\end{array}$ & Inherit from parent & Inherit from parent \\
\hline $\begin{array}{l}\text { machinelsystemlcurrentcontrolset| } \\
\text { controllcomputername }\end{array}$ & $\begin{array}{l}\text { Authenticated Users: } \\
\text { Read (key and subkeys) }\end{array}$ & $\begin{array}{l}\text { Authenticated Users: } \\
\text { Read (key and subkeys) }\end{array}$ \\
\hline $\begin{array}{l}\text { machinelsystemlcurrentcontrolsetl } \\
\text { controllcontentindex }\end{array}$ & $\begin{array}{l}\text { Authenticated Users: } \\
\text { Read (key and subkeys) }\end{array}$ & $\begin{array}{l}\text { Authenticated Users: } \\
\text { Read (key and subkeys) }\end{array}$ \\
\hline $\begin{array}{l}\text { machinelsystemlcurrentcontrolset| } \\
\text { controlkeyboard layout }\end{array}$ & $\begin{array}{l}\text { Authenticated Users: } \\
\text { Read (key and subkeys) }\end{array}$ & $\begin{array}{l}\text { Authenticated Users: } \\
\text { Read (key and subkeys) }\end{array}$ \\
\hline $\begin{array}{l}\text { machinelsystem } \mid \text { currentcontrolset } \mid \\
\text { controlkeyboard layouts }\end{array}$ & \begin{tabular}{|l|} 
Authenticated Users: \\
Read (key and subkeys) \\
\end{tabular} & $\begin{array}{l}\text { Authenticated Users: } \\
\text { Read (key and subkeys) }\end{array}$ \\
\hline $\begin{array}{l}\text { machinelsystemlcurrentcontrolsetl } \\
\text { controllprintlprinters }\end{array}$ & $\begin{array}{l}\text { Authenticated Users: } \\
\text { Read (key and subkeys) } \\
\end{array}$ & $\begin{array}{l}\text { Authenticated Users: } \\
\text { Read (key and subkeys) }\end{array}$ \\
\hline $\begin{array}{l}\text { machinelsystemlcurrentcontrolsetl } \\
\text { controllproductoptions }\end{array}$ & $\begin{array}{l}\text { Authenticated Users: } \\
\text { Read (key and subkeys) } \\
\end{array}$ & $\begin{array}{l}\text { Authenticated Users: } \\
\text { Read (key and subkeys) }\end{array}$ \\
\hline $\begin{array}{l}\text { machinelsystemlcurrentcontrolset } \\
\text { controllsecurepipeservers } \mid \text { winreg }\end{array}$ & $\begin{array}{l}\text { Administrators: Full } \\
\text { Control (key and subkeys) } \\
\text { (A;;GR;;BBO) }\end{array}$ & $\begin{array}{l}\text { Administrators: Full } \\
\text { Control (key and subkeys) } \\
\text { (A;;GR;;;BO) }\end{array}$ \\
\hline
\end{tabular}




\begin{tabular}{|c|c|c|}
\hline $\begin{array}{l}\text { machinelsystem/currentcontrolsetl } \\
\text { controllsession managerlexecutive }\end{array}$ & $\begin{array}{l}\text { Power Users: Read, Write, } \\
\text { and Delete (key and } \\
\text { subkeys) }\end{array}$ & $\begin{array}{l}\text { Power Users: Read, Write, } \\
\text { and Delete (key and } \\
\text { subkeys) }\end{array}$ \\
\hline $\begin{array}{l}\text { machinelsystemlcurrentcontrolset } \\
\text { controlltimezoneinformation }\end{array}$ & $\begin{array}{l}\text { Power Users: Read, Write, } \\
\text { and Delete (key and } \\
\text { subkeys) }\end{array}$ & $\begin{array}{l}\text { Power Users: Read, Write, } \\
\text { and Delete (key and } \\
\text { subkeys) }\end{array}$ \\
\hline $\begin{array}{l}\text { machinelsystemlcurrentcontrolset } \\
\text { controllwmilsecurity }\end{array}$ & $\begin{array}{l}\text { Administrators: Read } \\
\text { (key and subkeys) } \\
\text { SYSTEM: Full Control } \\
\text { (key and subkeys) } \\
\text { CREATOR OWNER: } \\
\text { Full Control (key and } \\
\text { subkeys) } \\
\end{array}$ & $\begin{array}{l}\text { Administrators: Read } \\
\text { (key and subkeys) } \\
\text { SYSTEM: Full Control } \\
\text { (key and subkeys) } \\
\text { CREATOR OWNER: } \\
\text { Full Control (key and } \\
\text { subkeys) }\end{array}$ \\
\hline $\begin{array}{l}\text { machinelsystemlcurrentcontrolset } \\
\text { enum }\end{array}$ & Inherit from parent & Inherit from parent \\
\hline $\begin{array}{l}\text { machinelsystem|currentcontrolset } \mid \\
\text { hardware profiles }\end{array}$ & Inherit from parent & Inherit from parent \\
\hline $\begin{array}{l}\text { machinelsystem/currentcontrolset। } \\
\text { servicesleventlog }\end{array}$ & $\begin{array}{l}\text { Authenticated Users: } \\
\text { Read (key and subkeys) }\end{array}$ & $\begin{array}{l}\text { Authenticated Users: } \\
\text { Read (key and subkeys) }\end{array}$ \\
\hline $\begin{array}{l}\text { machinelsystemlcurrentcontrolset } \\
\text { servicesltcpip }\end{array}$ & $\begin{array}{l}\text { Authenticated Users: } \\
\text { Read (key and subkeys) }\end{array}$ & $\begin{array}{l}\text { Authenticated Users: } \\
\text { Read (key and subkeys) } \\
\end{array}$ \\
\hline usersl.default & $\begin{array}{l}\text { Users: Read (key and } \\
\text { subkeys) } \\
\text { Power Users: Read (key } \\
\text { and subkeys) } \\
\text { Administrators: Full } \\
\text { Control (key and subkeys) } \\
\text { SYSTEM: Full Control } \\
\text { (key and subkeys) } \\
\text { CREATOR OWNER: } \\
\text { Full Control (key and } \\
\text { subkeys) }\end{array}$ & $\begin{array}{l}\text { Users: Read (key and } \\
\text { subkeys) } \\
\text { Power Users: Read (key } \\
\text { and subkeys) } \\
\text { Administrators: Full } \\
\text { Control (key and subkeys) } \\
\text { SYSTEM: Full Control } \\
\text { (key and subkeys) } \\
\text { CREATOR OWNER: } \\
\text { Full Control (key and } \\
\text { subkeys) }\end{array}$ \\
\hline $\begin{array}{l}\text { usersl.default/softwarelmicrosoft } \backslash \\
\text { netdde }\end{array}$ & $\begin{array}{l}\text { Administrators: Full } \\
\text { Control (key and subkeys) } \\
\text { SYSTEM: Full Control } \\
\text { (key and subkeys) } \\
\text { CREATOR OWNER: } \\
\text { Full Control (key and } \\
\text { subkeys) }\end{array}$ & $\begin{array}{l}\text { Administrators: Full } \\
\text { Control (key and subkeys) } \\
\text { SYSTEM: Full Control } \\
\text { (key and subkeys) } \\
\text { CREATOR OWNER: } \\
\text { Full Control (key and } \\
\text { subkeys) }\end{array}$ \\
\hline $\begin{array}{l}\text { users } \backslash \text {.default } \mid \text { softwarelmicrosoft } \backslash \\
\text { protected storage system provider }\end{array}$ & Inherit from parent & Inherit from parent \\
\hline
\end{tabular}




\section{FrLe SYSTEM}

The file system permissions and auditing are set in the File System area of the templates. The following file system objects are set by the Setup Security template. To view the individual permissions settings you will have to view the template with the Security Templates console. Here, \%SystemDrive\% is the boot drive letter (for example C:) and \%SystemRoot\% is the active Windows directory (for example, C:lwinnt or C:lwindows) \%SystemDirectory\% is the active System directory (for example, C:|windowsisystem32).

\begin{tabular}{|c|c|c|}
\hline ( )hiect Nime & Morkstation Permissions & Server Permissions \\
\hline$\%$ SystemDrive\%lautoexec.bat & $\begin{array}{l}\text { Users: Read and Execute } \\
\text { Power Users: Modify } \\
\text { Administrators: Full } \\
\text { Control } \\
\text { SYSTEM: Full Control }\end{array}$ & $\begin{array}{l}\text { Users: Read and Execute } \\
\text { Power Users: Modify } \\
\text { Administrators: Full } \\
\text { Control } \\
\text { SYSTEM: Full Control }\end{array}$ \\
\hline \%SystemDrive\%lboot.ini & $\begin{array}{l}\text { Power Users: Read and } \\
\text { Execute } \\
\text { Administrators: Full } \\
\text { Control } \\
\text { SYSTEM: Full Control }\end{array}$ & $\begin{array}{l}\text { Power Users: Read and } \\
\text { Execute } \\
\text { Administrators: Full } \\
\text { Control } \\
\text { SYSTEM: Full Control }\end{array}$ \\
\hline \%SystemDrive\%lconfig.sys & $\begin{array}{l}\text { Users: Read and Execute } \\
\text { Power Users: Modify } \\
\text { Administrators: Full } \\
\text { Control } \\
\text { SYSTEM: Full Control }\end{array}$ & $\begin{array}{l}\text { Users: Read and Execute } \\
\text { Power Users: Modify } \\
\text { Administrators: Full } \\
\text { Control } \\
\text { SYSTEM: Full Control }\end{array}$ \\
\hline \%SystemDrive\%lntbootdd.sys & $\begin{array}{l}\text { Power Users: Read and } \\
\text { Execute } \\
\text { Administrators: Full } \\
\text { Control } \\
\text { SYSTEM: Full Control } \\
\end{array}$ & $\begin{array}{l}\text { Power Users: Read and } \\
\text { Execute } \\
\text { Administrators: Full } \\
\text { Control } \\
\text { SYSTEM: Full Control }\end{array}$ \\
\hline \%SystemDrive\% Intdetect.com & $\begin{array}{l}\text { Power Users: Read and } \\
\text { Execute } \\
\text { Administrators: Full } \\
\text { Control } \\
\text { SYSTEM: Full Control }\end{array}$ & $\begin{array}{l}\text { Power Users: Read and } \\
\text { Execute } \\
\text { Administrators: Full } \\
\text { Control } \\
\text { SYSTEM: Full Control }\end{array}$ \\
\hline$\%$ SystemDrive\%lntldr & $\begin{array}{l}\text { Power Users: Read and } \\
\text { Execute } \\
\text { Administrators: Full } \\
\text { Control } \\
\text { SYSTEM: Full Control } \\
\end{array}$ & $\begin{array}{l}\text { Power Users: Read and } \\
\text { Execute } \\
\text { Administrators: Full } \\
\text { Control } \\
\text { SYSTEM: Full Control } \\
\end{array}$ \\
\hline \%SystemDrive\% /program files & $\begin{array}{l}\text { Users: Read and Execute } \\
\text { (folder, subfolders, and } \\
\text { files) } \\
\text { Power Users: Modify } \\
\text { (folder, subfolders, and } \\
\text { files) }\end{array}$ & $\begin{array}{l}\text { Users: Read and Execute } \\
\text { (folder, subfolders, and } \\
\text { files) } \\
\text { Power Users: Modify } \\
\text { (folder, subfolders, and } \\
\text { files) }\end{array}$ \\
\hline
\end{tabular}




\begin{tabular}{|c|c|c|}
\hline & $\begin{array}{l}\text { Administrators: Full } \\
\text { Control (folder, subfolder, } \\
\text { and files) } \\
\text { SYSTEM: Full Control } \\
\text { (folder, subfolder, and } \\
\text { files) } \\
\text { CREATOR OWNER: } \\
\text { Full Control (folder, } \\
\text { subfolder, and files) }\end{array}$ & $\begin{array}{l}\text { Administrators: Full } \\
\text { Control (folder, subfolder, } \\
\text { and files) } \\
\text { SYSTEM: Full Control } \\
\text { (folder, subfolder, and } \\
\text { files) } \\
\text { CREATOR OWNER: } \\
\text { Full Control (folder, } \\
\text { subfolder, and files) } \\
\text { Terminal Server Users: } \\
\text { Full Control (folder, } \\
\text { subfolder, and files) }\end{array}$ \\
\hline$\%$ SystemRoot $\%$ & $\begin{array}{l}\text { Users: Read and Execute } \\
\text { (folder, subfolders, and } \\
\text { files) } \\
\text { Power Users: Modify } \\
\text { (folder, subfolders, and } \\
\text { files) } \\
\text { Administrators: Full } \\
\text { Control (folder, subfolder, } \\
\text { and files) } \\
\text { SYSTEM: Full Control } \\
\text { (folder, subfolder, and } \\
\text { files) } \\
\text { CREATOR OWNER: } \\
\text { Full Control (folder, } \\
\text { subfolder, and files) } \\
\text { Authenticated Users: } \\
\text { Read and Execute }\end{array}$ & $\begin{array}{l}\text { Users: Read and Execute } \\
\text { (folder, subfolders, and } \\
\text { files) } \\
\text { Power Users: Modify } \\
\text { (folder, subfolders, and } \\
\text { files) } \\
\text { Administrators: Full } \\
\text { Control (folder, subfolder, } \\
\text { and files) } \\
\text { SYSTEM: Full Control } \\
\text { (folder, subfolder, and } \\
\text { files) } \\
\text { CREATOR OWNER: } \\
\text { Full Control (folder, } \\
\text { subfolder, and files) } \\
\text { Authenticated Users: } \\
\text { Read and Execute }\end{array}$ \\
\hline \%SystemRoot\%】default.pif & $\begin{array}{l}\text { Users: Read and Execute } \\
\text { Power Users: Read and } \\
\text { Execute } \\
\text { Administrators: Full } \\
\text { Control } \\
\text { SYSTEM: Full Control }\end{array}$ & $\begin{array}{l}\text { Users: Read and Execute } \\
\text { Power Users: Read and } \\
\text { Execute } \\
\text { Administrators: Full } \\
\text { Control } \\
\text { SYSTEM: Full Control }\end{array}$ \\
\hline \%SystemRoot\%laddins & $\begin{array}{l}\text { Users: Read and Execute } \\
\text { (folder, subfolders, and } \\
\text { files) } \\
\text { Power Users: Modify } \\
\text { (folders and subfolders) } \\
\text { Power Users Read and } \\
\text { Execute (folders, } \\
\text { subfolders, and files) } \\
\text { Administrators: Full } \\
\text { Control (folder, subfolder, } \\
\text { and files) }\end{array}$ & $\begin{array}{l}\text { Users: Read and Execute } \\
\text { (folder, subfolders, and } \\
\text { files) } \\
\text { Power Users: Modify } \\
\text { (folders and subfolders) } \\
\text { Power Users Read and } \\
\text { Execute (folders, } \\
\text { subfolders, and files) } \\
\text { Administrators: Full } \\
\text { Control (folder, subfolder, } \\
\text { and files) }\end{array}$ \\
\hline
\end{tabular}




\begin{tabular}{|c|c|c|}
\hline & $\begin{array}{l}\text { SYSTEM: Full Control } \\
\text { (folder, subfolder, and } \\
\text { files) } \\
\text { CREATOR OWNER: } \\
\text { Full Control (folder, } \\
\text { subfolder, and files) } \\
\end{array}$ & $\begin{array}{l}\text { SYSTEM: Full Control } \\
\text { (folder, subfolder, and } \\
\text { files) } \\
\text { CREATOR OWNER: } \\
\text { Full Control (folder, } \\
\text { subfolder, and files) } \\
\end{array}$ \\
\hline \%SystemRoot\%lclock.avi & $\begin{array}{l}\text { Users: Read and Execute } \\
\text { Power Users: Read and } \\
\text { Execute } \\
\text { Administrators: Full } \\
\text { Control } \\
\text { SYSTEM: Full Control }\end{array}$ & $\begin{array}{l}\text { Users: Read and Execute } \\
\text { Power Users: Read and } \\
\text { Execute } \\
\text { Administrators: Full } \\
\text { Control } \\
\text { SYSTEM: Full Control }\end{array}$ \\
\hline \%SystemRoot\%lconfiglgeneral.idf & $\begin{array}{l}\text { Users: Read and Execute } \\
\text { Power Users: Read and } \\
\text { Execute } \\
\text { Administrators: Full } \\
\text { Control } \\
\text { SYSTEM: Full Control }\end{array}$ & $\begin{array}{l}\text { Users: Read and Execute } \\
\text { Power Users: Read and } \\
\text { Execute } \\
\text { Administrators: Full } \\
\text { Control } \\
\text { SYSTEM: Full Control }\end{array}$ \\
\hline \%SystemRoot\%lconfiglhindered.idf & $\begin{array}{l}\text { Users: Read and Execute } \\
\text { Power Users: Read and } \\
\text { Execute } \\
\text { Administrators: Full } \\
\text { Control } \\
\text { SYSTEM: Full Control }\end{array}$ & $\begin{array}{l}\text { Users: Read and Execute } \\
\text { Power Users: Read and } \\
\text { Execute } \\
\text { Administrators: Full } \\
\text { Control } \\
\text { SYSTEM: Full Control }\end{array}$ \\
\hline \%SystemRoot\%lconfiglmsadlib.idf & $\begin{array}{l}\text { Users: Read and Execute } \\
\text { Power Users: Read and } \\
\text { Execute } \\
\text { Administrators: Full } \\
\text { Control } \\
\text { SYSTEM: Full Control }\end{array}$ & $\begin{array}{l}\text { Users: Read and Execute } \\
\text { Power Users: Read and } \\
\text { Execute } \\
\text { Administrators: Full } \\
\text { Control } \\
\text { SYSTEM: Full Control }\end{array}$ \\
\hline \%SystemRoot\%lconnection wizard & $\begin{array}{l}\text { Users: Read and Execute } \\
\text { (folder, subfolders, and } \\
\text { files) } \\
\text { Power Users: Read and } \\
\text { Execute (folder, } \\
\text { subfolders, and files) } \\
\text { Power Users: Modify } \\
\text { (folder sad subfolder) } \\
\text { Administrators: Full } \\
\text { Control (folder, subfolder, } \\
\text { and files) } \\
\text { SYSTEM: Full Control } \\
\text { (folder, subfolder, and } \\
\text { files) } \\
\text { CREATOR OWNER: } \\
\text { Full Control (folder, }\end{array}$ & $\begin{array}{l}\text { Users: Read and Execute } \\
\text { (folder, subfolders, and } \\
\text { files) } \\
\text { Power Users: Read and } \\
\text { Execute (folder, } \\
\text { subfolders, and files) } \\
\text { Power Users: Modify } \\
\text { (folder sad subfolder) } \\
\text { Administrators: Full } \\
\text { Control (folder, subfolder, } \\
\text { and files) } \\
\text { SYSTEM: Full Control } \\
\text { (folder, subfolder, and } \\
\text { files) } \\
\text { CREATOR OWNER: } \\
\text { Full Control (folder, }\end{array}$ \\
\hline
\end{tabular}




\begin{tabular}{|c|c|c|}
\hline & subfolder, and files) & subfolder, and files) \\
\hline$\%$ SystemRoot\%lcsc & Inherit from parent & Inherit from parent \\
\hline \%SystemRoot\%ldebuglusermode & $\begin{array}{l}\text { Users: Create Files and } \\
\text { Create Folders (files only) } \\
\text { Users: Traverse/Execute, } \\
\text { List/Read, Create files } \\
\text { (folder only) } \\
\text { Power Users: Modify } \\
\text { (folder, subfolders, and } \\
\text { files) } \\
\text { Administrators: Full } \\
\text { Control (folder, subfolder, } \\
\text { and files) } \\
\text { SYSTEM: Full Control } \\
\text { (folder, subfolder, and } \\
\text { files) }\end{array}$ & $\begin{array}{l}\text { Users: Create Files and } \\
\text { Create Folders (files only) } \\
\text { Users: Traverse/Execute, } \\
\text { List/Read, Create files } \\
\text { (folder only) } \\
\text { Power Users: Modify } \\
\text { (folder, subfolders, and } \\
\text { files) } \\
\text { Administrators: Full } \\
\text { Control (folder, subfolder, } \\
\text { and files) } \\
\text { SYSTEM: Full Control } \\
\text { (folder, subfolder, and } \\
\text { files) }\end{array}$ \\
\hline \%SystemRoot\%ldiscover.exe & $\begin{array}{l}\text { Users: Read and Execute } \\
\text { Power Users: Read and } \\
\text { Execute } \\
\text { Administrators: Full } \\
\text { Control } \\
\text { SYSTEM: Full Control }\end{array}$ & \\
\hline \%SystemRoot\%ldriver cache & $\begin{array}{l}\text { Users: Read and Execute } \\
\text { (folder, subfolders, and } \\
\text { files) } \\
\text { Power Users: Read and } \\
\text { Execute (folder, } \\
\text { subfolders, and files) } \\
\text { Power Users: Modify } \\
\text { (folder sad subfolder) } \\
\text { Administrators: Full } \\
\text { Control (folder, subfolder, } \\
\text { and files) } \\
\text { SYSTEM: Full Control } \\
\text { (folder, subfolder, and } \\
\text { files) } \\
\text { CREATOR OWNER: } \\
\text { Full Control (folder, } \\
\text { subfolder, and files) }\end{array}$ & $\begin{array}{l}\text { Users: Read and Execute } \\
\text { (folder, subfolders, and } \\
\text { files) } \\
\text { Power Users: Read and } \\
\text { Execute (folder, } \\
\text { subfolders, and files) } \\
\text { Power Users: Modify } \\
\text { (folder sad subfolder) } \\
\text { Administrators: Full } \\
\text { Control (folder, subfolder, } \\
\text { and files) } \\
\text { SYSTEM: Full Control } \\
\text { (folder, subfolder, and } \\
\text { files) } \\
\text { CREATOR OWNER: } \\
\text { Full Control (folder, } \\
\text { subfolder, and files) }\end{array}$ \\
\hline \%SystemRoot\%lexplorer.exe & $\begin{array}{l}\text { Users: Read and Execute } \\
\text { Power Users: Read and } \\
\text { Execute } \\
\text { Administrators: Full } \\
\text { Control } \\
\text { SYSTEM: Full Control } \\
\text { Authenticated Users: }\end{array}$ & $\begin{array}{l}\text { Users: Read and Execute } \\
\text { Power Users: Read and } \\
\text { Execute } \\
\text { Administrators: Full } \\
\text { Control } \\
\text { SYSTEM: Full Control } \\
\text { Authenticated Users: }\end{array}$ \\
\hline
\end{tabular}




\begin{tabular}{|c|c|c|}
\hline & Read and Execute & Read and Execute \\
\hline \%SystemRoot\%lexplorer.scf & $\begin{array}{l}\text { Users: Read and Execute } \\
\text { Power Users: Read and } \\
\text { Execute } \\
\text { Administrators: Full } \\
\text { Control } \\
\text { SYSTEM: Full Control }\end{array}$ & $\begin{array}{l}\text { Users: Read and Execute } \\
\text { Power Users: Read and } \\
\text { Execute } \\
\text { Administrators: Full } \\
\text { Control } \\
\text { SYSTEM: Full Control } \\
\text { Authenticated Users: } \\
\text { Read and Execute }\end{array}$ \\
\hline $\begin{array}{l}\text { \%SystemRoot\%lfonts } \\
\text { app850.fon, arial.ttf, arialbd.ttf, } \\
\text { arialbi.ttf, ariali.ttf, ariblk.ttf, } \\
\text { cga40850.fon, cga40woa.fon, } \\
\text { cga80850.fon, cga80woa.fon, } \\
\text { comic.ttf, comicbd.ttf, cour.ttf, } \\
\text { courbd.ttf, courbi.ttf, coure.fon, } \\
\text { courf.fon, couri.ttf, desktop.ini, } \\
\text { dosapp.fon, ega40850.fon, } \\
\text { ega40woa.fon, ega80850.fon, } \\
\text { ega80woa.fon, georgia.ttf, } \\
\text { georgiab.ttf, georgiai.ttf, } \\
\text { georgiaz.ttf, impact.ttf, 1_10646.ttf, } \\
\text { lucon.ttf, marlett.ttf, micross.ttf, } \\
\text { modern.fon, pala.ttf, palab.ttf, } \\
\text { palabi.ttf, palai.ttf, roman.fon, } \\
\text { script.fon, serife.fon, seriff.fon, } \\
\text { smalle.fon, sserife.fon, sseriff.fon, } \\
\text { symbol.ttf, symbole.fon, tahoma.ttf, } \\
\text { tahomabd.ttf, times.ttf, timesbd.ttf, } \\
\text { timesbi.ttf, timesi.ttf, trebuc.ttf, } \\
\text { trebucbd.ttf, trebucbi.ttf, trebucit.ttf, } \\
\text { verdana.ttf, verdanab.ttf, } \\
\text { verdanai.ttf, verdanaz.ttf, } \\
\text { vga850.fon, vgafix.fon, } \\
\text { vgaoem.fon, vgasys.fon, } \\
\text { webdings.ttf, wingding.ttf }\end{array}$ & $\begin{array}{l}\text { Users: Read and Execute } \\
\text { Power Users: Read and } \\
\text { Execute } \\
\text { Administrators: Full } \\
\text { Control } \\
\text { SYSTEM: Full Control }\end{array}$ & $\begin{array}{l}\text { Users: Read and Execute } \\
\text { Power Users: Read and } \\
\text { Execute } \\
\text { Administrators: Full } \\
\text { Control } \\
\text { SYSTEM: Full Control }\end{array}$ \\
\hline$\%$ Systemroot\%lHelp & & $\begin{array}{l}\text { Users: Read and Execute } \\
\text { (folder, subfolders, and } \\
\text { files) } \\
\text { Power Users: Modify } \\
\text { (folder, subfolders, and } \\
\text { files) } \\
\text { Administrators: Full } \\
\text { Control (folder, subfolder, }\end{array}$ \\
\hline
\end{tabular}




\begin{tabular}{|c|c|c|}
\hline & & $\begin{array}{l}\text { and files) } \\
\text { SYSTEM: Full Control } \\
\text { (folder, subfolder, and } \\
\text { files) } \\
\text { CREATOR OWNER: } \\
\text { Full Control (folder, } \\
\text { subfolder, and files) } \\
\text { Terminal Server Users: } \\
\text { Read, Write, and Execute } \\
\text { (folder, subfolders, and } \\
\text { files) }\end{array}$ \\
\hline 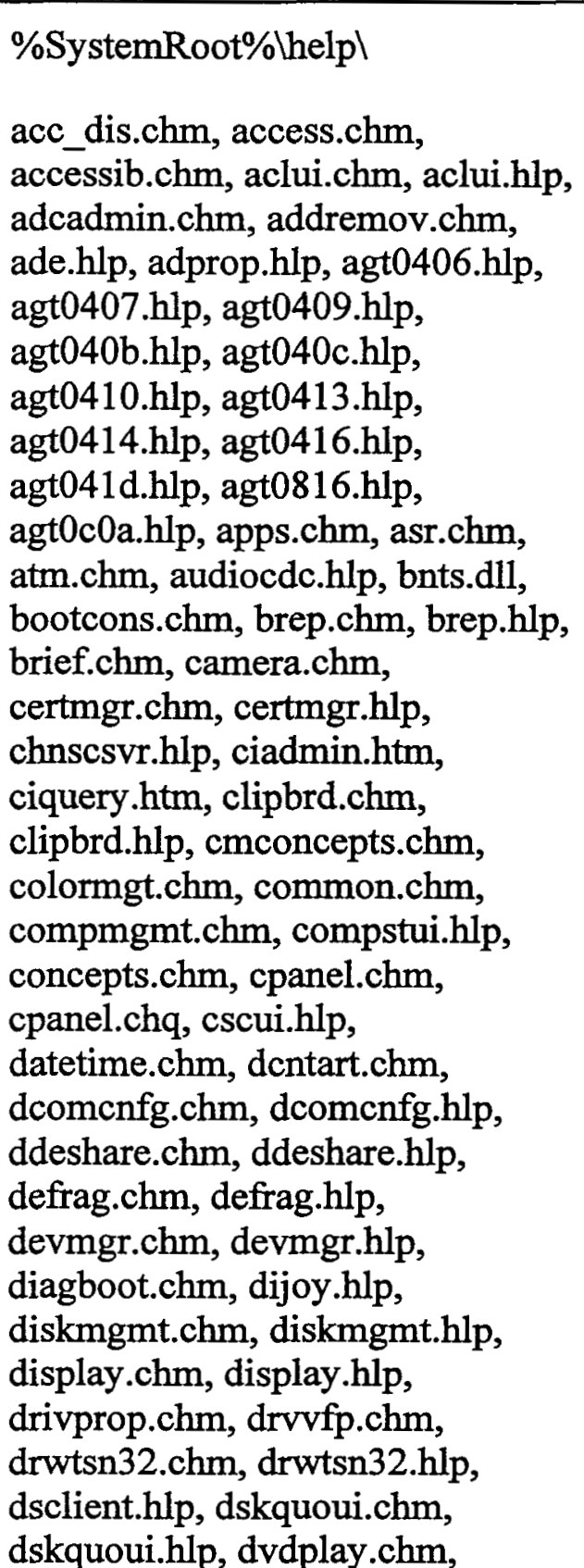 & $\begin{array}{l}\text { Users: Read and Execute } \\
\text { Power Users: Read and } \\
\text { Execute } \\
\text { Administrators: Full } \\
\text { Control } \\
\text { SYSTEM: Full Control }\end{array}$ & $\begin{array}{l}\text { Users: Read and Execute } \\
\text { Power Users: Read and } \\
\text { Execute } \\
\text { Administrators: Full } \\
\text { Control } \\
\text { SYSTEM: Full Control }\end{array}$ \\
\hline
\end{tabular}


dvdplay.hlp, dxdiag.chm, els.chm, els.hlp, encrypt.chm, errors.chm, eudcedit.chm, eudcedit.hlp, evntwin.hlp, fax.chm, fax.hlp, faxcover.chm, faxmgmt.chm, faxqueue.chm, fde.hlp, file_srv.chm, file_srv.hlp, filemgmt.hlp, find.chm, folderop.chm, fonts.chm, fonts.hlp, getstart.chm, glossary.chm, glossary.hlp, gpedit.chm, gpedit.hlp, gptext.hlp, halftone.hlp, hardware.chm, hardware.hlp, howto.chm, ident.hlp, ieakmmc.chm, iesupp.chm, iewebhlp.chm, iexplore.chm, iexplore.hlp, iis.chm, iismmc.chm, imghelp.hlp, imgmgt.chm, imgmgt.hlp, imgtasks.chm, imgview.chm, infrared.chm, infrared.hlp, intellimirror.chm, ipsecconcepts.chm, ipsecsnp.chm, ipsecsnp.hlp, is.chm, isconcepts.chm, ixhelp.hlp, ixqlang.htm, javaperm.hlp, javasec.hlp, joy.chm, keyb.chm, lang.chm, license.chm, localsec.chm, localsec.hlp, magnify.chm, magnify.hlp, mail.chm, mfcuix.hlp, mls_trb.chm, mmc.chm, mmc_dlg.hlp, mmdrv.hlp, mobsync.chm, mobsync.hlp, mode.chm, modem.hlp, mouse.chm, mouse.hlp, mpconcepts.chm, mplayer2.cnt, mplayer2.hlp, mpnetwrk.hlp, mqsnap.hlp, msdasc.chm, msinfo32.chm, msinfo32.hlp, msmq.chm, msmqconcepts.chm, msmqcpl.chm, msmqcpl.hlp, msnauth.cnt, msnauth.hlp, msorcl32.chm, mstask.chm, netcfg.chm, netcfg.hlp, newfeat1.chm, newfeat1.hlp, newfeat 2.chm, newfeat 2.hlp, newfeat3.chm, newfeat3.hlp, 
newfeat4.chm, newfeat4.hlp, newfeat5.chm, newfeat5.hlp, nocontnt.cnt, nofts.chm, notepad.chm, notepad.hlp, ntart.chm, ntbackup.chm, ntbackup.hlp, ntchowto.chm, ntcmds.chm, ntdef.chm, nthelp.chm, ntshared.chm, ntshrui.chm, ntshrui.hlp, nwdoc.chm, nwdoc.hlp, objsel.hlp, odbcinst.chm, odbcjet.chm, offlinefolders.chm, omc.chm, osk.chm, osk.hlp, printfnd.chm, printing.chm, proccon.chm, progman.cnt, progman.hlp, pwrmn.chm, pwrmn.hlp, rasadmin.cnt, rasadmin.hlp, ratings.chm, ratings.cnt, ratings.hlp, reader.chm, reader.hlp, recycle.chm, regedit.chm, regedit.hlp, regedt32.chm, regedt32.hlp, regopt.chm, remote.chm, rsm.chm, rsm.hlp, rsmconcepts.chm, sc.chm, scarddlg.hlp, sce.chm, sceconcepts.chm, scenario.chm, scm.chm, scmconcepts.chm, secauth.hlp, secedit.chm, secsetconcepts.chm, secsettings.chm, sendcmsg.chm, sfmmgr.hlp, shell.hlp, signin.hlp, sigverif.hlp, smlogcfg.chm, snmpconcepts.chm, snmpsnap.hlp, soundrec.chm, soundrec.hlp, sounds.chm, spconcepts.chm, splash.chm, supp_ed.chm, sys_srv.chm, sys_srv.hlp, sysdm.chm, sysdm.hlp, sysmon.chm, sysmon.hlp, sysprop.chm, tapi.chm, tapi.hlp, taskmgr.chm, taskmgr.hlp, tcpip.chm, tcpmon.hlp, telnet.chm, telnet.hlp, trouble.chm, tshoot.chm, tshoot.chq, tshoot.hlp, tshoot.ocx, update.cnt, upwizun.chm, usercpl.chm, users.hlp, 


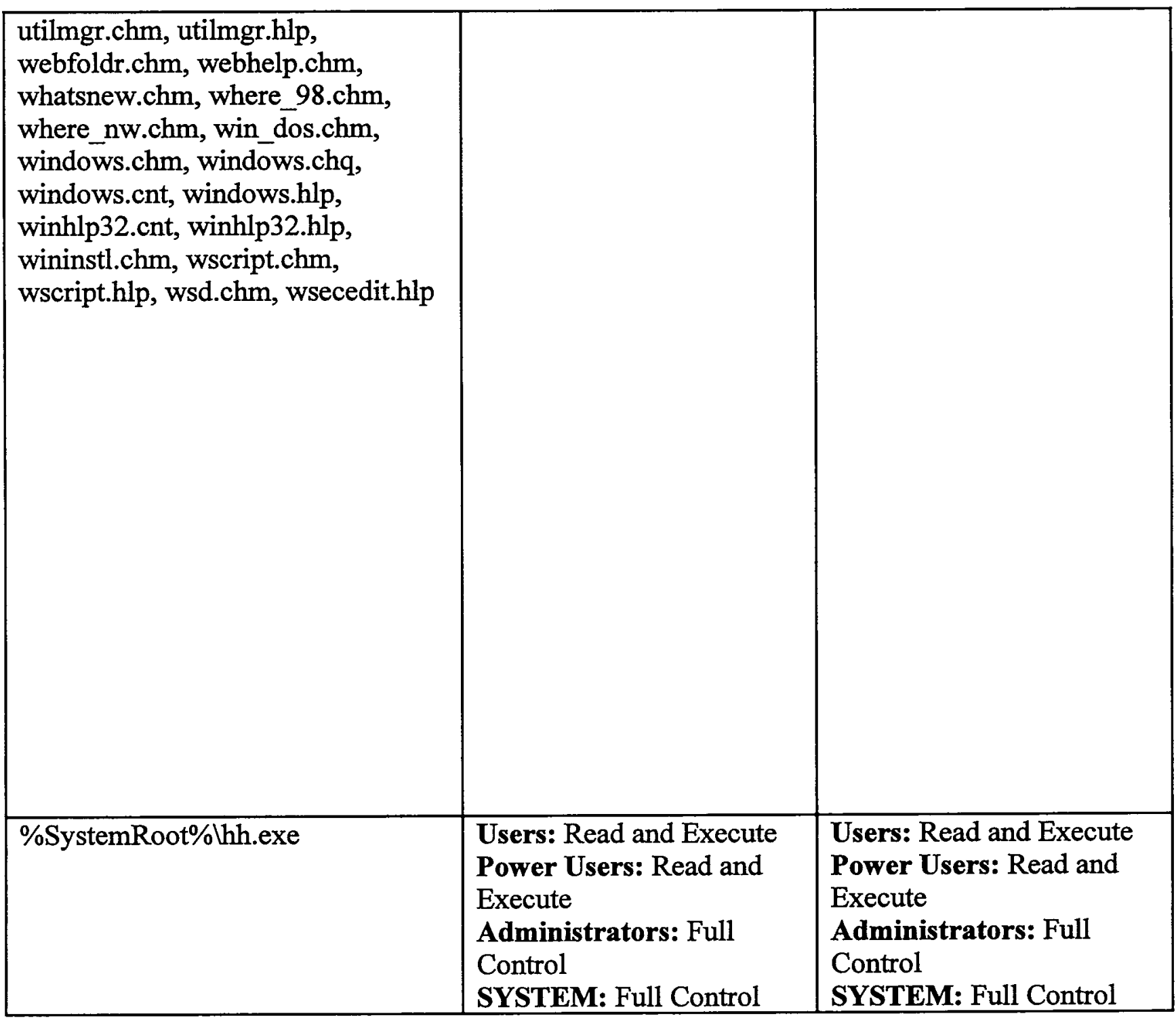




\begin{tabular}{|c|c|c|}
\hline $\begin{array}{l}\text { \%SystemRoot\%linf } \\
\text { 1394.inf, accessor.inf, acpi.inf, } \\
\text { adm_mult.inf, adm_port.inf, } \\
\text { agtinst.inf, amovie.inf, } \\
\text { apcompat.inf, apps.inf, } \\
\text { asynceqn.inf, atividin.inf, } \\
\text { avmisdn.inf, axant5.inf, } \\
\text { banshee.inf, battery.inf, } \\
\text { biosinfo.inf, ccdecode.inf, } \\
\text { cdrom.inf, certclas.inf, } \\
\text { cfmcanon.inf, cfmmustk.inf, } \\
\text { cfmricoh.inf, chips5.inf, } \\
\text { communic.inf, comnt5.inf, } \\
\text { conf.adm, corelist.inf, ctlegacy.inf, } \\
\text { ctmaport.inf, ctmvport.inf, } \\
\text { defltsv.inf, defltwk.inf, dfrg.inf, } \\
\text { dgaport.inf, dgasync.inf, didiva.inf, } \\
\text { digiisdn.inf, digirp.inf, digirprt.inf, } \\
\text { disk.inf, dispdet.inf, display.inf, } \\
\text { dot4.inf, dot4prt.inf, drvindex.inf, } \\
\text { dshowext.inf, dtcnt5.inf, dvd.inf, } \\
\text { eclandd.inf, ecwandd.inf, } \\
\text { eiccard.inf, eicpcard.inf, } \\
\text { eicvirta.inf, eqnport.inf, } \\
\text { faxsetup.inf, fdc.inf, ftscan.inf, } \\
\text { flash.inf, flpydisk.inf, font.inf, } \\
\text { fp40ext.inf, fsvga.inf, fsvgaadd.inf, } \\
\text { fsvgadel.inf, gameport.inf, } \\
\text { games.inf, genprint.inf, hal.inf, } \\
\text { hidserv.inf, hpojscan.inf, } \\
\text { hpscan.inf, i740nt5.inf, i81xnt5.inf, } \\
\text { ibmsync.inf, ibmvcap.inf, } \\
\text { icminst.inf, icwnt5.inf, ie.inf, } \\
\text { iereset.inf, iis.inf, iisdbg.inf, } \\
\text { image.inf, imagevue.inf, ims.inf, } \\
\text { inetcorp.adm, inetres.adm, } \\
\text { inetset.adm, input.inf, intl.inf, } \\
\text { irdaalif.inf, irdasmc.inf, irnsc.inf, } \\
\text { irtos4mo.inf, irtos4mu.inf, } \\
\text { kdk2x0.inf, keyboard.inf, kodak.inf, } \\
\text { ks.inf, kscaptur.inf, ksfilter.inf, } \\
\text { layout.inf, legcydrv.inf, } \\
\text { logiscan.inf, lvcam.inf, lvcomp.inf, } \\
\text { lvsound.inf, lwngmadi.inf, } \\
\text { lwusbhid.inf, machine.inf, }\end{array}$ & $\begin{array}{l}\text { Users: Read and Execute } \\
\text { Power Users: Read and } \\
\text { Execute } \\
\text { Administrators: Full } \\
\text { Control } \\
\text { SYSTEM: Full Control }\end{array}$ & $\begin{array}{l}\text { Users: Read and Execute } \\
\text { Power Users: Read and } \\
\text { Execute } \\
\text { Administrators: Full } \\
\text { Control } \\
\text { SYSTEM: Full Control }\end{array}$ \\
\hline
\end{tabular}




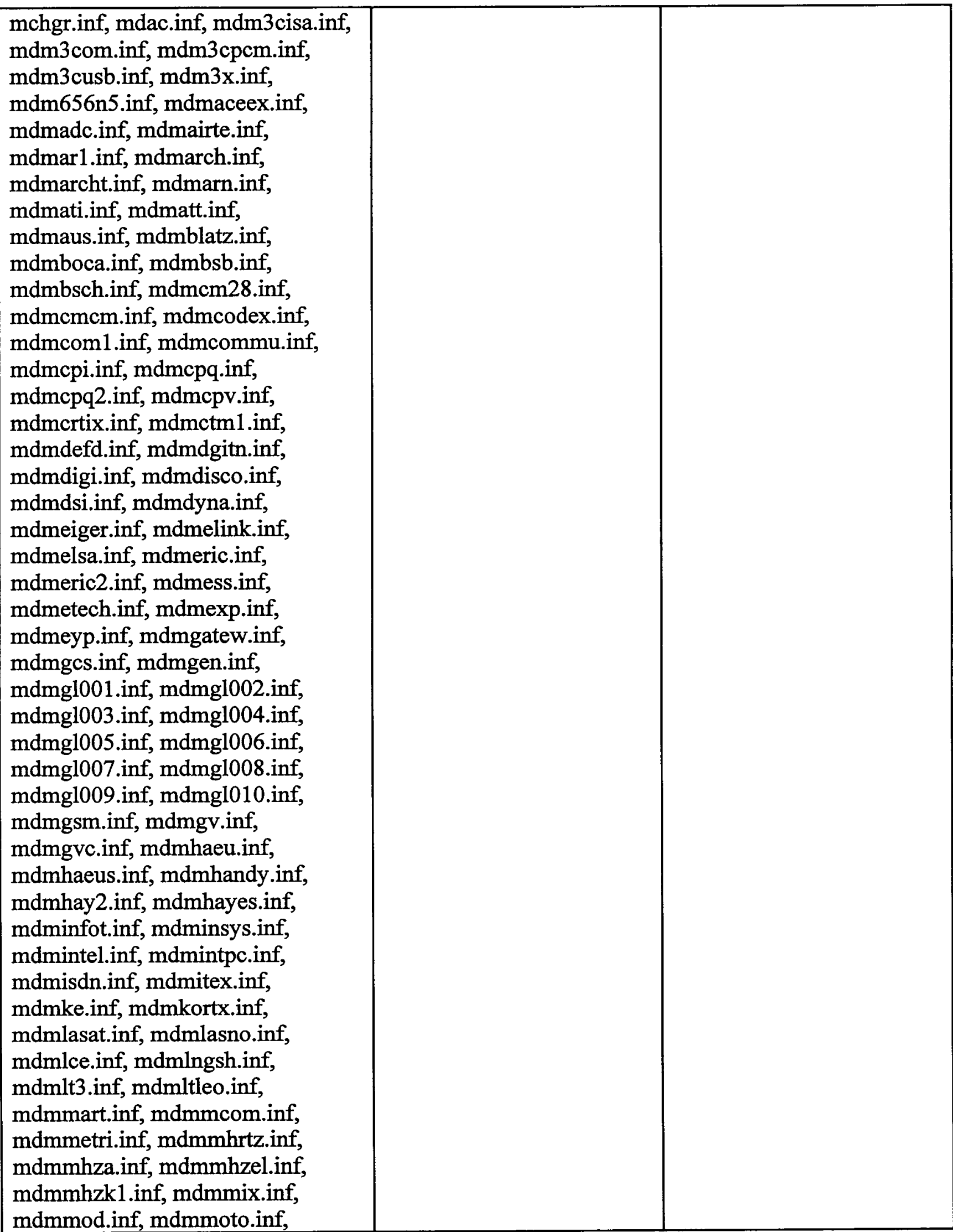




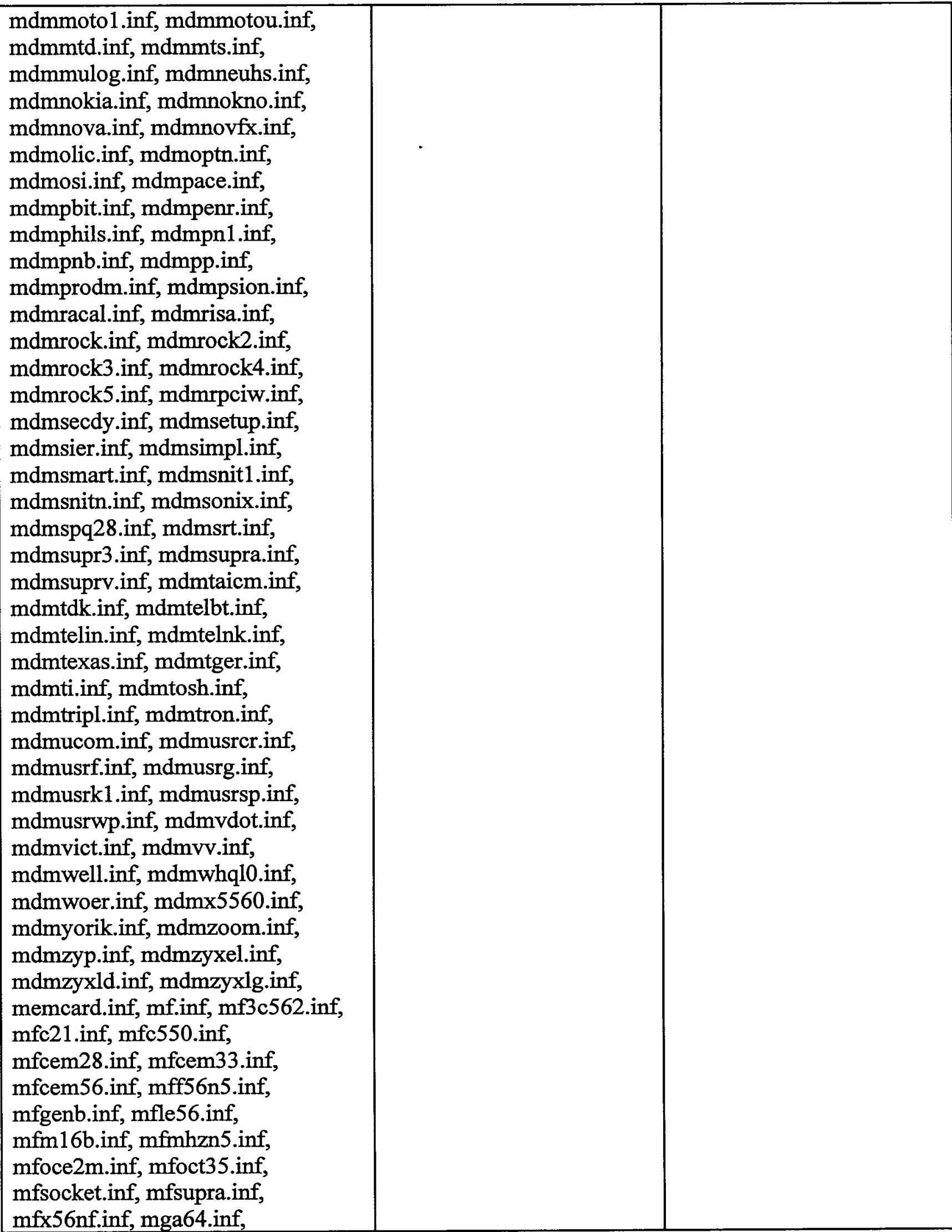




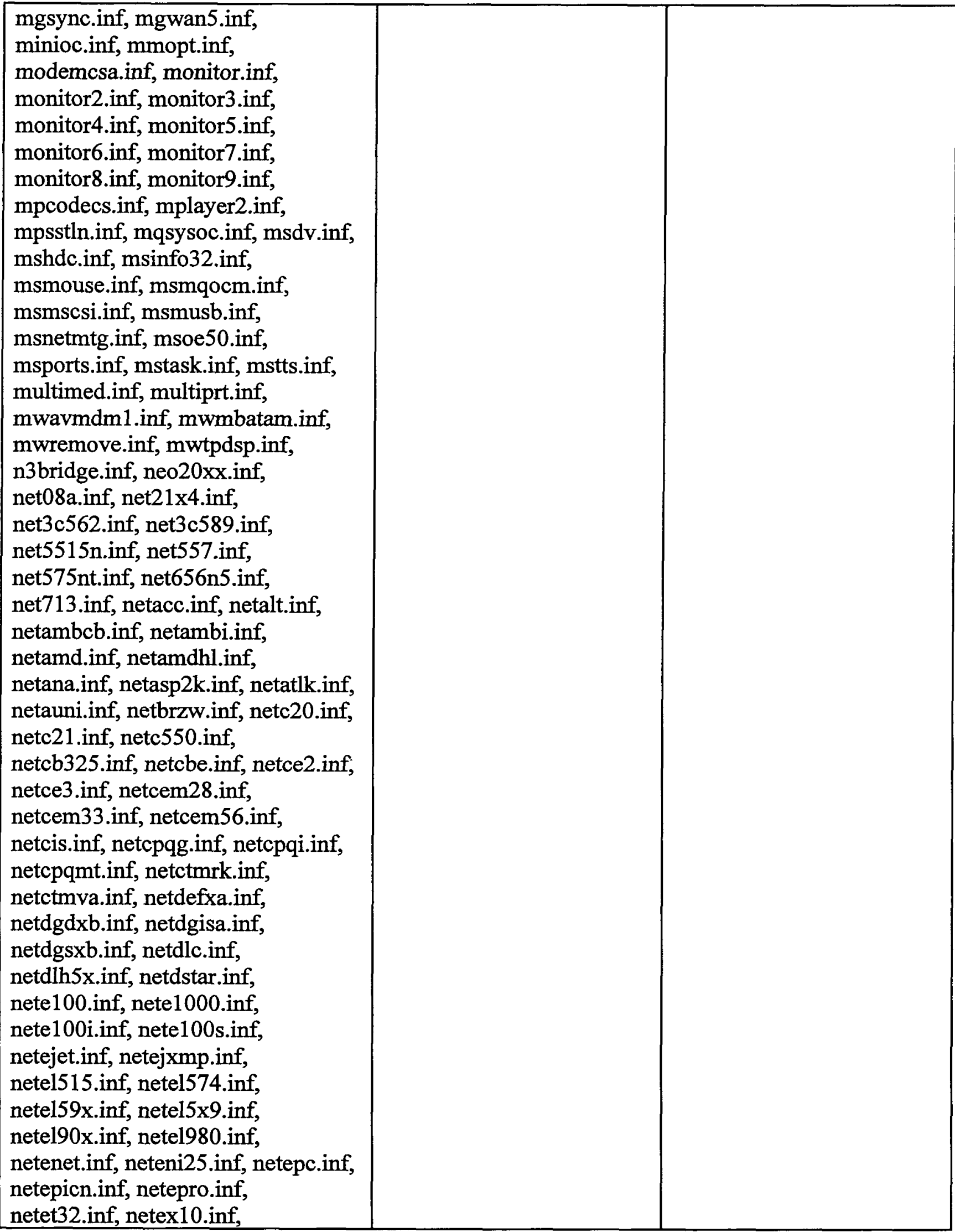




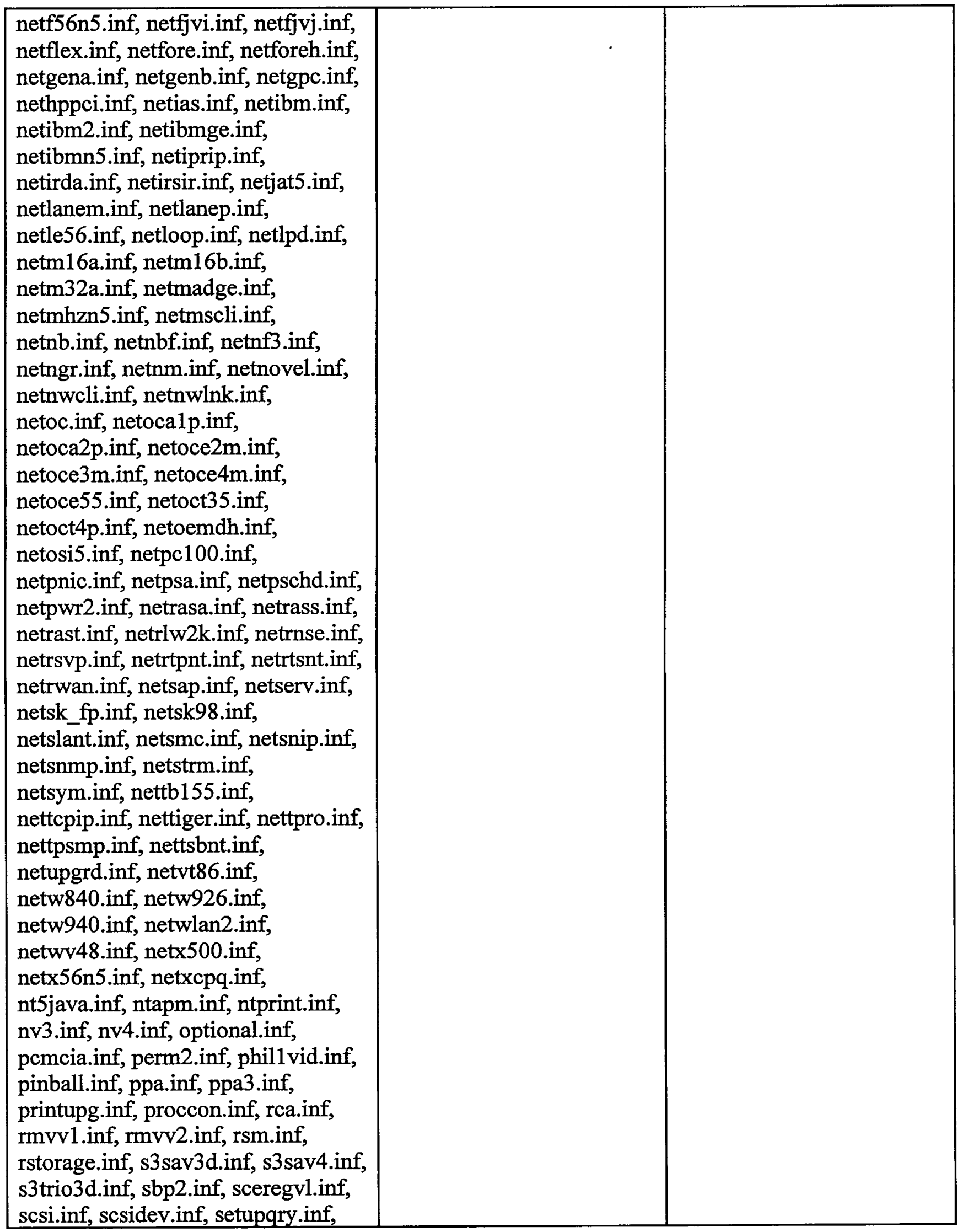




\begin{tabular}{|c|c|c|}
\hline $\begin{array}{l}\text { sgiu.inf, shell.inf, sis300.inf, } \\
\text { sis6306.inf, sisv6326.inf, } \\
\text { smartcrd.inf, spchapi.inf, spx.inf, } \\
\text { spxports.inf, stalport.inf, sti.inf, } \\
\text { stillcam.inf, svcpack.inf, swnt.inf, } \\
\text { sysoc.inf, syssetup.inf, system.adm, } \\
\text { tape.inf, tgiu.inf, trid3d.inf, } \\
\text { tridkb.inf, tsbvcap.inf, tshoot.inf, } \\
\text { umax.inf, unknown.inf, } \\
\text { unregmp2.exe, usb.inf, usbprint.inf, } \\
\text { usbstor.inf, usermig.inf, volume.inf, } \\
\text { voodoo3.inf, wab50.inf, } \\
\text { wanmgfr.inf, wanmgs.inf, wave.inf, } \\
\text { wbemnt5.inf, wbfirdma.inf, } \\
\text { wbfirdma.sys, wdma_adi.inf, } \\
\text { wdma_aur.inf, wdma_ava.inf, } \\
\text { wdma_azt.inf, wdma_csc.inf, } \\
\text { wdma_csf.inf, wdma_ctl.inf, } \\
\text { wdma_ens.inf, wdma_es2.inf, } \\
\text { wdma_ess.inf, wdma_int.inf, } \\
\text { wdma_ne2.inf, wdma_neo.inf, } \\
\text { wdma_usb.inf, wdma_wss.inf, } \\
\text { wdma_ym2.inf, wdma_ymh.inf, } \\
\text { wdma10k1.inf, wdmaudio.inf, } \\
\text { wdmjoy.inf, wkstamig.inf, } \\
\text { wmp.adm, wordpad.inf }\end{array}$ & - & \\
\hline \%SystemRoot\%ljava & $\begin{array}{l}\text { Users: Read and Execute } \\
\text { (folder, subfolders, and } \\
\text { files) } \\
\text { Power Users: Read and } \\
\text { Execute (folder, } \\
\text { subfolders, and files) } \\
\text { Power Users: Modify } \\
\text { (folder sad subfolder) } \\
\text { Administrators: Full } \\
\text { Control (folder, subfolder, } \\
\text { and files) } \\
\text { SYSTEM: Full Control } \\
\text { (folder, subfolder, and } \\
\text { files) } \\
\text { CREATOR OWNER: } \\
\text { Full Control (folder, } \\
\text { subfolder, and files) }\end{array}$ & $\begin{array}{l}\text { Users: Read and Execute } \\
\text { (folder, subfolders, and } \\
\text { files) } \\
\text { Power Users: Read and } \\
\text { Execute (folder, } \\
\text { subfolders, and files) } \\
\text { Power Users: Modify } \\
\text { (folder sad subfolder) } \\
\text { Administrators: Full } \\
\text { Control (folder, subfolder, } \\
\text { and files) } \\
\text { SYSTEM: Full Control } \\
\text { (folder, subfolder, and } \\
\text { files) } \\
\text { CREATOR OWNER: } \\
\text { Full Control (folder, } \\
\text { subfolder, and files) } \\
\end{array}$ \\
\hline \%Systemroot\%llanma256.bmp & & $\begin{array}{l}\text { Users: Read and Execute } \\
\text { Power Users: Read and } \\
\text { Execute }\end{array}$ \\
\hline
\end{tabular}




\begin{tabular}{|c|c|c|}
\hline & & $\begin{array}{l}\text { Administrators: Full } \\
\text { Control } \\
\text { SYSTEM: Full Control }\end{array}$ \\
\hline \%Systemroot\%llanmannt.bmp & & $\begin{array}{l}\text { Users: Read and Execute } \\
\text { Power Users: Read and } \\
\text { Execute } \\
\text { Administrators: Full } \\
\text { Control } \\
\text { SYSTEM: Full Control }\end{array}$ \\
\hline $\begin{array}{l}\text { \%SystemRoot\%lmedial } \\
\text { ir_begin.wav, ir_end.wav, } \\
\text { ir_inter.wav, ringin.wav, } \\
\text { ringout.wav, start.wav, the } \\
\text { microsoft sound.wav, windows } \\
\text { logoff sound.wav, windows logon } \\
\text { sound.wav }\end{array}$ & $\begin{array}{l}\text { Users: Read and Execute } \\
\text { Power Users: Read and } \\
\text { Execute } \\
\text { Administrators: Full } \\
\text { Control } \\
\text { SYSTEM: Full Control }\end{array}$ & $\begin{array}{l}\text { Users: Read and Execute } \\
\text { Power Users: Read and } \\
\text { Execute } \\
\text { Administrators: Full } \\
\text { Control } \\
\text { SYSTEM: Full Control }\end{array}$ \\
\hline \%SystemRoot\%lmsagent & $\begin{array}{l}\text { Users: Read and Execute } \\
\text { (folder, subfolders, and } \\
\text { files) } \\
\text { Power Users: Read and } \\
\text { Execute (folder, } \\
\text { subfolders, and files) } \\
\text { Power Users: Modify } \\
\text { (folder sad subfolder) } \\
\text { Administrators: Full } \\
\text { Control (folder, subfolder, } \\
\text { and files) } \\
\text { SYSTEM: Full Control } \\
\text { (folder, subfolder, and } \\
\text { files) } \\
\text { CREATOR OWNER: } \\
\text { Full Control (folder, } \\
\text { subfolder, and files) }\end{array}$ & $\begin{array}{l}\text { Users: Read and Execute } \\
\text { (folder, subfolders, and } \\
\text { files) } \\
\text { Power Users: Read and } \\
\text { Execute (folder, } \\
\text { subfolders, and files) } \\
\text { Power Users: Modify } \\
\text { (folder sad subfolder) } \\
\text { Administrators: Full } \\
\text { Control (folder, subfolder, } \\
\text { and files) } \\
\text { SYSTEM: Full Control } \\
\text { (folder, subfolder, and } \\
\text { files) } \\
\text { CREATOR OWNER: } \\
\text { Full Control (folder, } \\
\text { subfolder, and files) }\end{array}$ \\
\hline \%SystemRoot\%lmsdfmap.ini & $\begin{array}{l}\text { Users: Read and Execute } \\
\text { Power Users: Read and } \\
\text { Execute } \\
\text { Administrators: Full } \\
\text { Control } \\
\text { SYSTEM: Full Control }\end{array}$ & $\begin{array}{l}\text { Users: Read and Execute } \\
\text { Power Users: Read and } \\
\text { Execute } \\
\text { Administrators: Full } \\
\text { Control } \\
\text { SYSTEM: Full Control } \\
\end{array}$ \\
\hline \%SystemRoot\%loffline pages & Inherit from parent & Inherit from parent \\
\hline \%Systemroot\%lpoledit.exe & & $\begin{array}{l}\text { Users: Read and Execute } \\
\text { Power Users: Read and } \\
\text { Execute } \\
\text { Administrators: Full } \\
\text { Control }\end{array}$ \\
\hline
\end{tabular}




\begin{tabular}{|c|c|c|}
\hline & & SYSTEM: Full Control \\
\hline \%SystemRoot\%lprofiles & Inherit from parent & Inherit from parent \\
\hline \%SystemRoot\%lregedit.exe & $\begin{array}{l}\text { Users: Read and Execute } \\
\text { Power Users: Read and } \\
\text { Execute } \\
\text { Administrators: Full } \\
\text { Control } \\
\text { SYSTEM: Full Control }\end{array}$ & $\begin{array}{l}\text { Users: Read and Execute } \\
\text { Power Users: Read and } \\
\text { Execute } \\
\text { Administrators: Full } \\
\text { Control } \\
\text { SYSTEM: Full Control }\end{array}$ \\
\hline \%SystemRoot\%lregistration & Inherit from parent & Inherit from parent \\
\hline \%SystemRoot\%lrepair & $\begin{array}{l}\text { Users: Read and Execute } \\
\text { (folder and subfolders) } \\
\text { Power Users: Modify } \\
\text { (folder, subfolders, and } \\
\text { files) } \\
\text { Administrators: Full } \\
\text { Control (folder, subfolder, } \\
\text { and files) } \\
\text { SYSTEM: Full Control } \\
\text { (folder, subfolder, and } \\
\text { files) } \\
\text { CREATOR OWNER: } \\
\text { Full Control (folder, } \\
\text { subfolder, and files) }\end{array}$ & $\begin{array}{l}\text { Users: Read and Execute } \\
\text { (folder and subfolders) } \\
\text { Power Users: Modify } \\
\text { (folder, subfolders, and } \\
\text { files) } \\
\text { Administrators: Full } \\
\text { Control (folder, subfolder, } \\
\text { and files) } \\
\text { SYSTEM: Full Control } \\
\text { (folder, subfolder, and } \\
\text { files) } \\
\text { CREATOR OWNER: } \\
\text { Full Control (folder, } \\
\text { subfolder, and files) }\end{array}$ \\
\hline \%SystemRoot\%lsecurity & $\begin{array}{l}\text { Users: Read and Execute } \\
\text { (folder, subfolders, and } \\
\text { files) } \\
\text { Power Users: Read and } \\
\text { Execute (folder, } \\
\text { subfolders, and files) } \\
\text { Administrators: Full } \\
\text { Control (folder, subfolder, } \\
\text { and files) } \\
\text { SYSTEM: Full Control } \\
\text { (folder, subfolder, and } \\
\text { files) } \\
\text { CREATOR OWNER: } \\
\text { Full Control (folder, } \\
\text { subfolder, and files) }\end{array}$ & $\begin{array}{l}\text { Users: Read and Execute } \\
\text { (folder, subfolders, and } \\
\text { files) } \\
\text { Power Users: Read and } \\
\text { Execute (folder, } \\
\text { subfolders, and files) } \\
\text { Administrators: Full } \\
\text { Control (folder, subfolder, } \\
\text { and files) } \\
\text { SYSTEM: Full Control } \\
\text { (folder, subfolder, and } \\
\text { files) } \\
\text { CREATOR OWNER: } \\
\text { Full Control (folder, } \\
\text { subfolder, and files) }\end{array}$ \\
\hline \%SystemRoot\%lspeech & $\begin{array}{l}\text { Users: Read and Execute } \\
\text { (folder, subfolders, and } \\
\text { files) } \\
\text { Power Users: Read and } \\
\text { Execute (folder, } \\
\text { subfolders, and files) } \\
\text { Power Users: Modify } \\
\text { (folder sad subfolder) }\end{array}$ & $\begin{array}{l}\text { Users: Read and Execute } \\
\text { (folder, subfolders, and } \\
\text { files) } \\
\text { Power Users: Read and } \\
\text { Execute (folder, } \\
\text { subfolders, and files) } \\
\text { Power Users: Modify } \\
\text { (folder sad subfolder) }\end{array}$ \\
\hline
\end{tabular}




\begin{tabular}{|c|c|c|}
\hline & $\begin{array}{l}\text { Administrators: Full } \\
\text { Control (folder, subfolder, } \\
\text { and files) } \\
\text { SYSTEM: Full Control } \\
\text { (folder, subfolder, and } \\
\text { files) } \\
\text { CREATOR OWNER: } \\
\text { Full Control (folder, } \\
\text { subfolder, and files) }\end{array}$ & $\begin{array}{l}\text { Administrators: Full } \\
\text { Control (folder, subfolder, } \\
\text { and files) } \\
\text { SYSTEM: Full Control } \\
\text { (folder, subfolder, and } \\
\text { files) } \\
\text { CREATOR OWNER: } \\
\text { Full Control (folder, } \\
\text { subfolder, and files) }\end{array}$ \\
\hline \%SystemRoot\%lsystem.ini & $\begin{array}{l}\text { Users: Read and Execute } \\
\text { Power Users: Read and } \\
\text { Execute } \\
\text { Administrators: Full } \\
\text { Control } \\
\text { SYSTEM: Full Control } \\
\end{array}$ & $\begin{array}{l}\text { Users: Read and Execute } \\
\text { Power Users: Read and } \\
\text { Execute } \\
\text { Administrators: Full } \\
\text { Control } \\
\text { SYSTEM: Full Control } \\
\end{array}$ \\
\hline \%SystemRoot\%lsystem/setup.inf & $\begin{array}{l}\text { Users: Read and Execute } \\
\text { Power Users: Read and } \\
\text { Execute } \\
\text { Administrators: Full } \\
\text { Control } \\
\text { SYSTEM: Full Control }\end{array}$ & $\begin{array}{l}\text { Users: Read and Execute } \\
\text { Power Users: Read and } \\
\text { Execute } \\
\text { Administrators: Full } \\
\text { Control } \\
\text { SYSTEM: Full Control }\end{array}$ \\
\hline \%SystemRoot\%Isystemlstdole.tlb & $\begin{array}{l}\text { Users: Read and Execute } \\
\text { Power Users: Read and } \\
\text { Execute } \\
\text { Administrators: Full } \\
\text { Control } \\
\text { SYSTEM: Full Control }\end{array}$ & $\begin{array}{l}\text { Users: Read and Execute } \\
\text { Power Users: Read and } \\
\text { Execute } \\
\text { Administrators: Full } \\
\text { Control } \\
\text { SYSTEM: Full Control }\end{array}$ \\
\hline$\%$ SystemDirectory\% & $\begin{array}{l}\text { Users: Read and Execute } \\
\text { (folder, subfolders, and } \\
\text { files) } \\
\text { Power Users: Modify } \\
\text { (folder, subfolders, and } \\
\text { files) } \\
\text { Administrators: Full } \\
\text { Control (folder, subfolder, } \\
\text { and files) } \\
\text { SYSTEM: Full Control } \\
\text { (folder, subfolder, and } \\
\text { files) } \\
\text { CREATOR OWNER: } \\
\text { Full Control (folder, } \\
\text { subfolder, and files) } \\
\text { Authenticated Users: } \\
\text { Read and Execute }\end{array}$ & $\begin{array}{l}\text { Users: Read and Execute } \\
\text { (folder, subfolders, and } \\
\text { files) } \\
\text { Power Users: Modify } \\
\text { (folder, subfolders, and } \\
\text { files) } \\
\text { Administrators: Full } \\
\text { Control (folder, subfolder, } \\
\text { and files) } \\
\text { SYSTEM: Full Control } \\
\text { (folder, subfolder, and } \\
\text { files) } \\
\text { CREATOR OWNER: } \\
\text { Full Control (folder, } \\
\text { subfolder, and files) } \\
\text { Authenticated Users: } \\
\text { Read and Execute }\end{array}$ \\
\hline
\end{tabular}




\begin{tabular}{|c|c|c|}
\hline $\begin{array}{l}\text { \%SystemDirectory\% } \\
\text { clbcatq.dll, 12520437.cpx, } \\
\text { 12520850.cpx, aaaamon.dll, } \\
\text { acelpdec.ax, acledit.dll, aclui.dll, } \\
\text { acsetupc.dll, acsmib.dll, } \\
\text { activeds.dll, activeds.tlb, } \\
\text { actmovie.exe, actxprxy.dll, } \\
\text { admparse.dll, adptif.dll, adsldp.dll, } \\
\text { adsldpc.dll, adsmsext.dll, } \\
\text { adsnds.dll, adsnt.dll, adsnw.dll, } \\
\text { advapi32.dll, advpack.dll, } \\
\text { alrsvc.dll, amstream.dll, ansi.sys, } \\
\text { apcups.dll, append.exe, } \\
\text { appmgmts.dll, appmgr.dll, } \\
\text { appwiz.cpl, arp.exe, asctrls.ocx, } \\
\text { asfsipc.dll, asycfilt.dll, at.exe, } \\
\text { atkctrs.dll, atl.dll, atmadm.exe, } \\
\text { atmfd.dll, atmlib.dll, attrib.exe, } \\
\text { autochk.exe, autoconv.exe, } \\
\text { autofmt.exe, autolfn.exe, avicap.dll, } \\
\text { avicap32.dll, avifil32.dll, avifile.dll, } \\
\text { basenote.cov, basesrv.dll, } \\
\text { batmeter.dll, bios1.rom, bios4.rom, } \\
\text { bootok.exe, bootvid.dll, } \\
\text { bootvrfy.exe, br549.dll, } \\
\text { browselc.dll, browser.dll, } \\
\text { browseui.dll, c_037.nls, } \\
\text { c_10000.nls, c_10079.nls, } \\
\text { c_1026.nls, c_1250.nls, c_1251.nls, } \\
\text { c_1252.nls, c_1253.nls, c_1254.nls, } \\
\text { c_1255.nls, c_1256.nls, c_1257.nls, } \\
\text { c_1258.nls, c_20261.nls, } \\
\text { c_20866.nls, c_20905.nls, } \\
\text { c_21866.nls, c_28591.nls, } \\
\text { c_28592.nls, c_28593.nls, } \\
\text { c_28598.nls, c_28605.nls, } \\
\text { c_437.nls, c_500.nls, c_775.nls, } \\
\text { c_850.nls, c_860.nls, c_861.nls, } \\
\text { c_863.nls, c_865.nls, c_874.nls, } \\
\text { c_932.nls, c_936.nls, c_949.nls, } \\
\text { c_950.nls, cabinet.dll, cabview.dll, } \\
\text { cacls.exe, capesnpn.dll, cards.dll, } \\
\text { catroot, ccfgnt.dll, cdfview.dll, } \\
\text { cdm.dll, cdonts.dll, cdosys.dll, } \\
\text { certcli.dll, certmgr.dll, certmgr.msc, } \\
\text { cfgmgr32.dll, channel screen }\end{array}$ & $\begin{array}{l}\text { Users: Read and Execute } \\
\text { Power Users: Read and } \\
\text { Execute } \\
\text { Administrators: Full } \\
\text { Control } \\
\text { SYSTEM: Full Control } \\
\text { Authenticated Users: } \\
\text { Read and Execute }\end{array}$ & $\begin{array}{l}\text { Users: Read and Execute } \\
\text { Power Users: Read and } \\
\text { Execute } \\
\text { Administrators: Full } \\
\text { Control } \\
\text { SYSTEM: Full Control } \\
\text { Authenticated Users: } \\
\text { Read and Execute }\end{array}$ \\
\hline
\end{tabular}


saver.scr, chcp.com, chkdsk.exe, chkntfs.exe, ciadmin.dll, ciadv.msc, cic.dll, cidaemon.exe, ciodm.dll, cipher.exe, cisvc.exe, ckcnv.exe, clb.dll, cleanmgr.exe, cliconf.hlp, cliconfg.dll, cliconfg.exe, clipsrv.exe, clspack.exe, clusapi.dll, cluster.exe, cmcfg32.dll, cmd.exe, cmdial32.dll, cmdl32.exe, cmmgr32.exe, cmmgr32.hlp, cmmon32.exe, cmnquery.dll, cmpbk32.dll, cmprops.dll, cmstp.exe, cmutil.dll, cnbjmon.dll, cnetcfg.dll, cnvfat.dll, comcat.dll, comctl32.dll, comdlg32.dll, comm.drv, command.com, commdlg.dll, comp.exe, compact.exe, compmgmt.msc, compobj.dll, compstui.dll, config, confmsp.dll, conime.exe, console.dll, control.exe, convert.exe, corpol.dll, country.sys, crtdll.dll, crypt32.dll, cryptdlg.dll, cryptdll.dll, cryptext.dll, cryptnet.dll, cryptsve.dll, cryptui.dll, cscdll.dll, cscript.exe, cscui.dll, csrsrv.dll, csrss.exe, ctl3d32.dll, ctl3dv2.dll, ctype.nls, d3dim.dll, d3dim700.dll, d3dpmesh.dll, d3dramp.dll, d3dref.dll, d3drm.dll, d3dxof.dll, danim.dll, dataclen.dll, datime.dll, daxctle.ocx, dbghelp.dll, dbmsadsn.dll, dbmsrpen.dll, dbmssocn.dll, dbmsspxn.dll, dbmsvinn.dll, dbnmpntw.dll, dciman32.dll, dcomcnfg.exe, ddeml.dll, ddeshare.exe, ddmprxy.exe, ddraw.dll, ddrawex.dll, debug.exe, desk.cpl, deskadp.dll, deskmon.dll, deskperf.dll, devenum.dll, devmgmt.msc, devmgr.dll, dfrg.msc, dfrgfat.exe, dfrgntfs.exe, dfrgres.dll, dfrgsnap.dll, dfrgui.dll, dfsshlex.dll, dhep, dhcpcsvc.dll, 


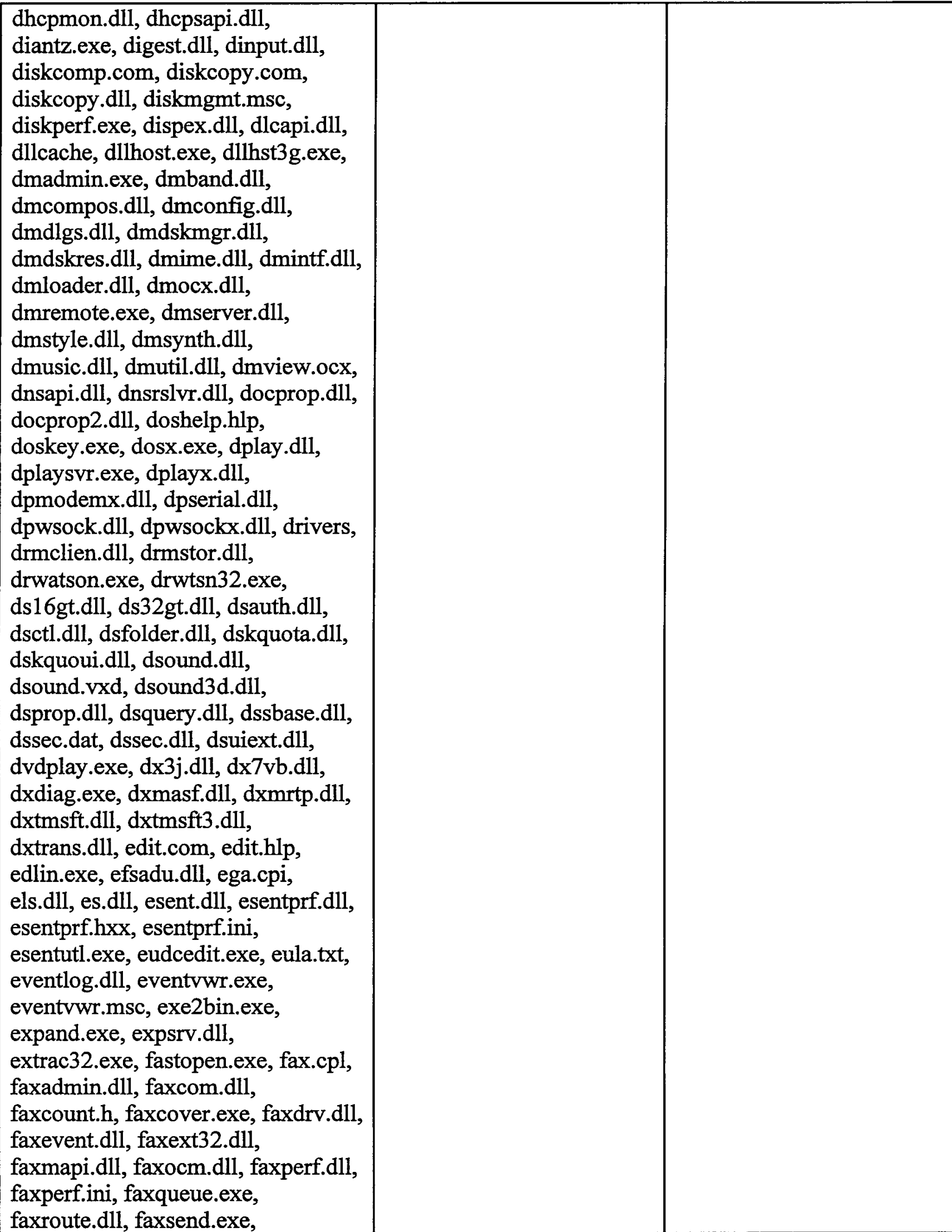




faxserv.msc, faxshell.dll,
faxsvc.exe, faxt30.dll, faxtiff.dll,
faxui.dll, faxxp32.dll, fc.exe,
fde.dll, fdeploy.dll, feclient.dll,
filemgmt.dll, find.exe, findstr.exe,
finger.exe, fixmapi.exe, fmifs.dll,
fontext.dll, fontsub.dll,
fontview.exe, forcedos.exe,
format.com, fsmgmt.msc, ftp.exe,
ftsrch.dll, g711codc.ax,
g723codc.ax, gcdef.dll, gdi.exe,
gdi32.dll, getstart.gif, glmf32.dll,
glu32.dll, gpedit.dll, gpedit.msc,
gpkcsp.dll, gpkrsrc.dll, gptext.dll,
graftabl.com, graphics.com,
graphics.pro, grpconv.exe,
h261_32.ax, h263_32.ax, h323.tsp,
h323msp.dll, hardware.inf,
hdwwiz.cpl, help.exe, hhctrl.ocx,
hhsetup.dll, hid.dll, himem.sys,
hlink.dll, homepage.inf,
hostname.exe, hotplug.dll, htui.dll,
iac25_32.ax, ias, ias.msc,
iasacct.dll, iasads.dll, iashlpr.dll,
iasnap.dll, iasperf.dll, iasperf.h,
iasperf.ini, iaspipe.dll, iaspolcy.dll,
iasrad.dll, iasrecst.dll, iassam.dll,
iassdo.dll, iassvcs.dll, iasuserr.dll,
iccvid.dll, icm32.dll, icmp.dll,
icmui.dll, idq.dll, idwlog.exe,
ie4uinit.exe, ieakeng.dll, ieaksie.dll,
ieakui.dll, iedkcs32.dll, iepeers.dll,
iernonce.dll, iesetup.dll,
ieshwiz.exe, ieuinit.inf,
iexpress.exe, ifmon.dll, ifsutil.dll,
igmpagnt.dll, iissuba.dll,
imaadp32.acm, imagehlp.dll,
imeshare.dll, imgutil.dll, imm32.dll,
indicdll.dll, inetcpl.cpl, inetcplc.dll,
inetmib1.dll, inetpp.dll, infosoft.dll,
initpki.dll, inseng.dll, instcat.sql,
instcm.inf, internat.exe, intl.cpl,
iologmsg.dll, ipconf.tsp,
ipconfig.exe, iphlpapi.dll,
ipmont.dll, ipnathlp.dll,
ing.dll,iprop.dll,iprtprio.dll,
ippromon.dll, iprop.dll, iprtprio.dll, 
iprtrmgr.dll, ipsecmon.exe, ipsecsnp.dll, ipxmontr.dll, ipxpromn.dll, ipxrip.dll, ipxroute.exe, ipxrtmgr.dll, ipxsap.dll, ipxwan.dll, ir32_32.dll, ir41_32.ax, ir41_qc.dll, ir41_qcx.dll, ir50 32.dll, ir50_qc.dll, ir50_qcx.dll, irclass.dll, irftp.exe, irmon. $\overline{d l l}$, irprops.cpl, itircl.dll, itss.dll, ivfsrc.ax, ixsso.dll, javacypt.dll, javaprxy.dll, javart.dll, jdbgmgr.exe, jet500.dll, jit.dll, jobexec.dll, joy.cpl, jscript.dll, jsproxy.dll, jview.exe, kb16.com, kbdbe.dll, kbdbene.dll, kbdbr.dll, kbdca.dll, kbdcan.dll, kbdda.dll, kbddv.dll, kbdes.dll, kbdfc.dll, kbdfi.dll, kbdfo.dll, kbdfr.dll, kbdgae.dll, kbdgr.dll, kbdgr1.dll, kbdic.dll, kbdir.dll, kbdit.dll, kbdit142.dll, kbdla.dll, kbdmac.dll, kbdne.dll, kbdno.dll, kbdpo.dll, kbdsf.dll, kbdsg.dll, kbdsp.dll, kbdsw.dll, kbduk.dll, kbdus.dll, kbdusl.dll, kbdusr.dll, kbdusx.dll, kerberos.dll, kernel32.dll, key01.sys, keyboard.drv, keyboard.sys, kmddsp.tsp, krnl386.exe, ksqmf.ax, 1_except.nls, 1 intl.nls, 13 codecx.ax, label.exe, lanman.drv, legacy.inf, licmgr10.dll, lights.exe, linkinfo.dll, lmhsvc.dll, lmrt.dll, lnkstub.exe, loadfix.com, loadperf.dll, locale.nls, localsec.dll, localspl.dll, localui.dll, locator.exe, lodctr.exe, logdrive.dll, loghours.dll, login.cmd, logon.scr, lpk.dll, lpq.exe, lpr.exe, lprhelp.dll, lprmonui.dll, lsasrv.dll, lsass.exe, lusrmgr.msc, lz32.dll, lzexpand.dll, mag_hook.dll, magnify.exe, main.cpl, makecab.exe, mapistub.dll, mbslgn32.dll, mcastmib.dll, mcd32.dll, mcdsrv32.dll, mciavi.drv, mciavi32.dll, mcicda.dll, 
mciole16.dll, mciole32.dll, mciqtz32.dll, mciseq.dll, mciseq.drv, mciwave.dll, mciwave.drv, mdhcp.dll, mdminst.dll, mem.exe, mf3216.dll, mfc40.dll, mfc40u.dll, mfc42.dll, mfc42u.dll, mfcsubs.dll, mgmtapi.dll, mib.bin, midimap.dll, migisol.exe, migpwd.exe, mimefilt.dll, mlang.dat, mlang.dll, mll_hp.dll, mll_mtf.dll, mll_qic.dll, mmc.exe, mmcndmgr.dll, mmcshext.dll, mmdet.dll, mmdriver.inf, mmdrv.dll, mmefxe.ocx, mmfutil.dll, mmsys.cpl, mmsystem.dll, mmtask.tsk, mmutilse.dll, mobsync.dll, mobsync.exe, mode.com, modemui.dll, modex.dll, more.com, moricons.dll, mountvol.exe, mouse.drv, mpg2splt.ax, mpg4ds32.ax, mpnotify.exe, mpr.dll, mprapi.dll, mprddm.dll, mprdim.dll, mprmsg.dll, mprui.dll, mrinfo.exe, msacm.dll, msacm32.dll, msacm32.drv, msadds32.ax, msadp32.acm, msafd.dll, msapsspc.dll, msasn1.dll, msaudite.dll, msawt.dll, mscat32.dll, mscdexnt.exe, msclus.dll, mscms.dll, mscpxl32.dll, msdart32.dll, msdatsrc.tlb, msdxm.ocx, msdxmlc.dll, msencode.dll, msexch40.dll, msexc140.dll, msfaxmon.dll, msg711.acm, msgina.dll, msgsm $32 . a c m$, msgsvc.dll, mshta.exe, mshtml.dll, mshtml.tlb, mshtmled.dll, mshtmler.dll, msi.dll, msident.dll, msidle.dll, msidlpm.dll, msidntld.dll, msidpe.dll, msieftp.dll, msiexec.exe, msihnd.dll, msimg32.dll, msimsg.dll, msjava.dll, 


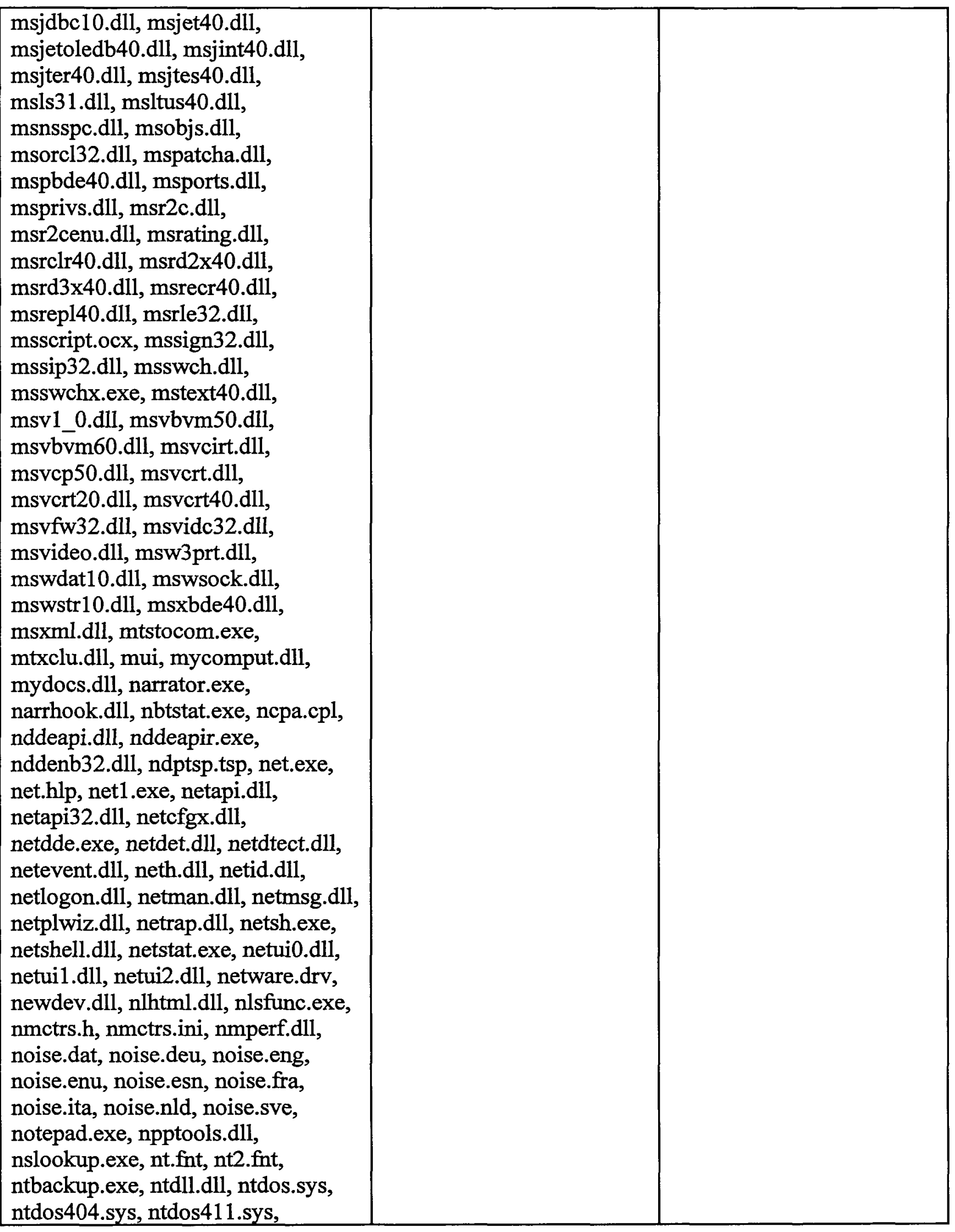




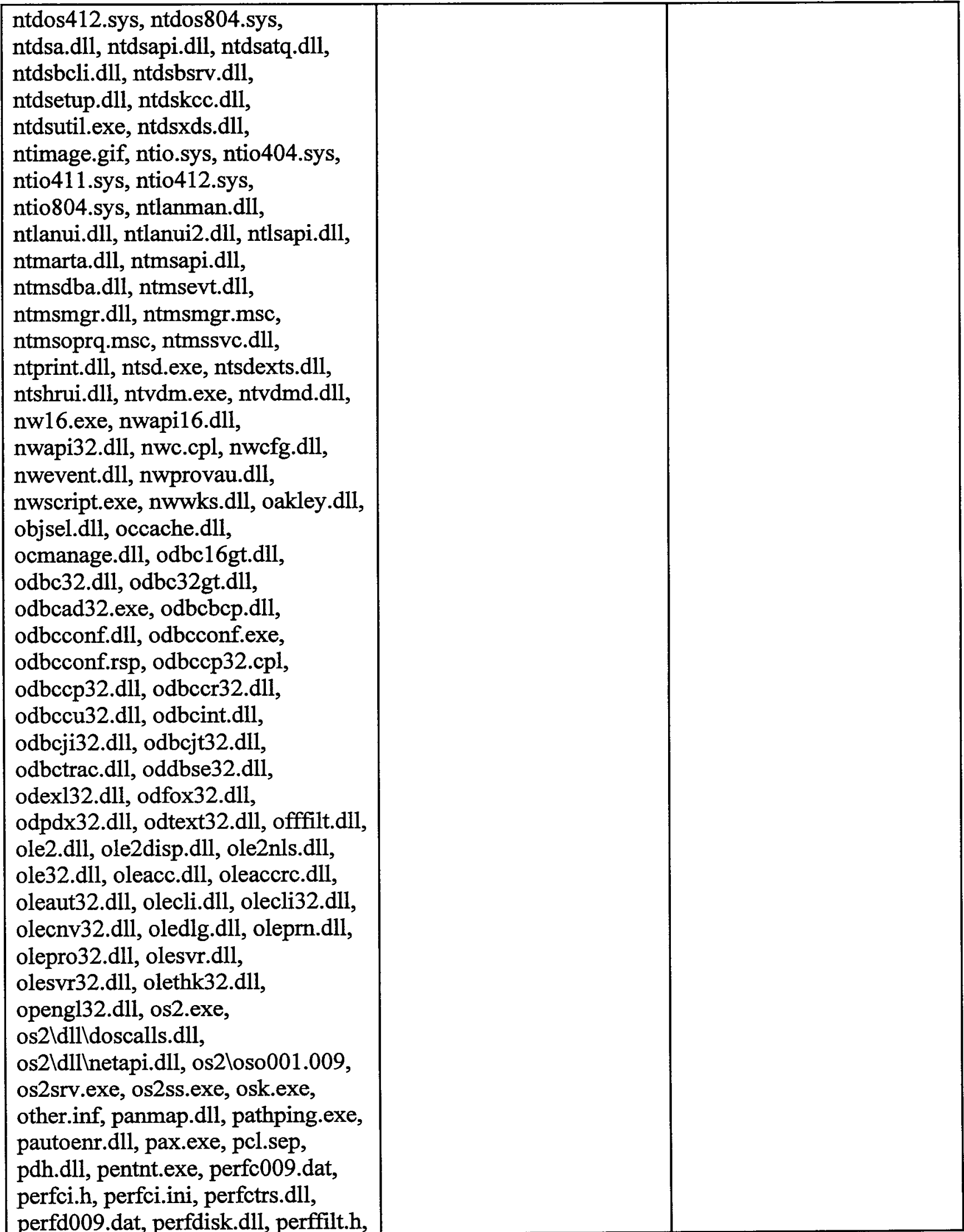




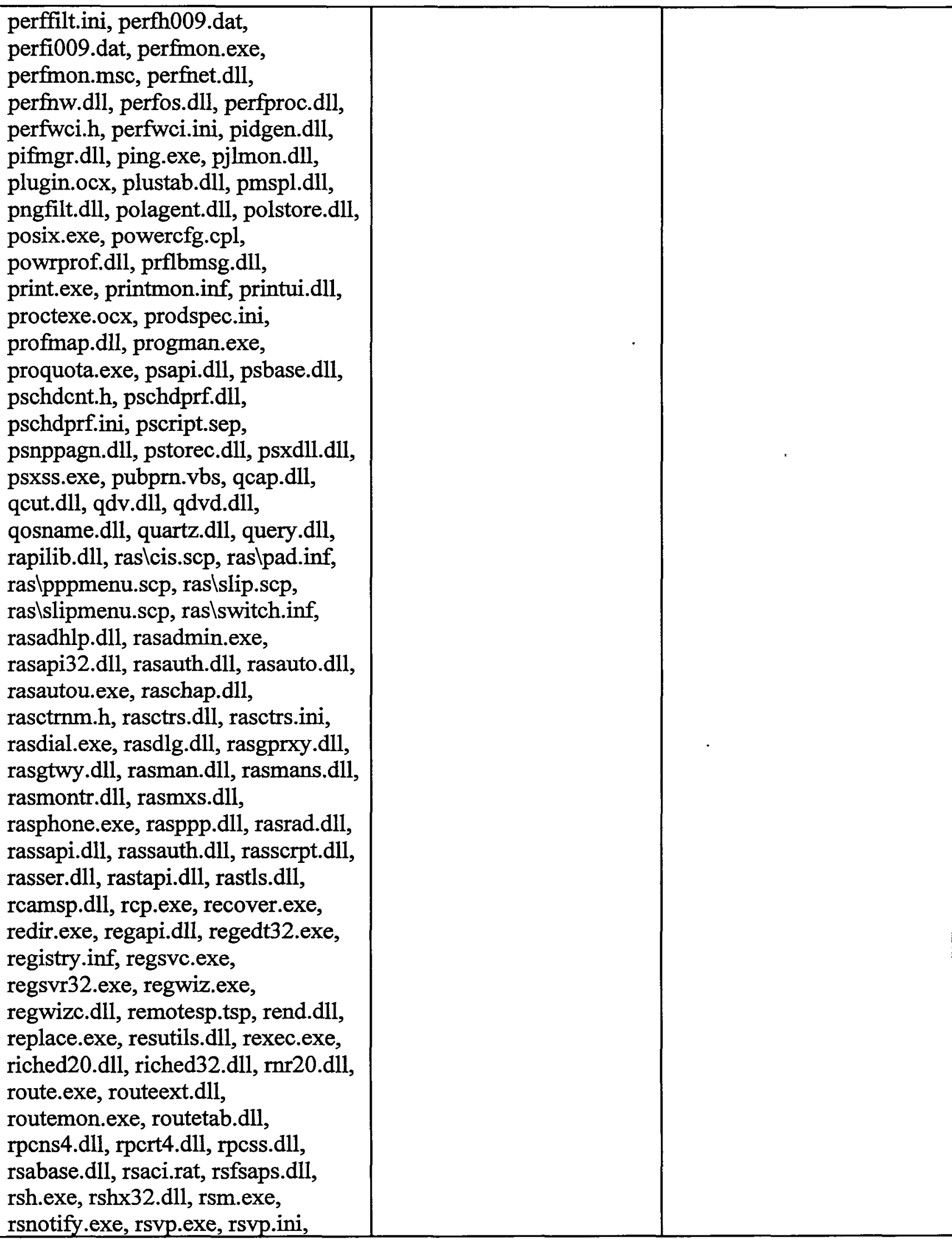


rsvpcnts.h, rsvpmsg.dll, rsvpperf.dll, rsvpsp.dll, rtipxmib.dll, rtm.dll, rtutils.dll, runas.exe, rundll32.exe, runonce.exe, samlib.dll, samsrv.dll, savedump.exe, scarddlg.dll, scardssp.dll, scardsvr.exe, scecli.dll, scesrv.dll, schannel.dll, sclgntfy.dll, scripto.dll, scrnsave.scr, scrobj.dll, scrrun.dll, sdpblb.dll, secedit.exe, seclogon.dll, secpol.msc, secur32.dll, security.dll, sefilshr.dll, sendcmsg.dll, sendmail.dll, sens.dll, sensapi.dll, senscfg.dll, serialui.dll, servdeps.dll, services.exe, services.msc, serwvdrv.dll, sethc.exe, setreg.exe, setup.bmp, setup.exe, setupapi.dll, setupdll.dll, setver.exe, sfc.dll, sfc.exe, sfcfiles.dll, sfmapi.dll, sfmatmsg.dll, sfmmon.dll, sfmwshat.dll, share.exe, shdoclc.dll, shdocvw.dll, shell.dll, shell32.dll, shellext, shfolder.dll, shim.dll, shimgvw.dll, shlwapi.dll, shmgrate.exe, shrpubw.exe, shscrap.dll, sigtab.dll, sigverif.exe, sisbkup.dll, skdll.dll, skeys.exe, slbcsp.dll, slbkygen.dll, slbrsrc.dll, smlogcfg.dll, smlogsvc.exe, smss.exe, snmpapi.dll, snmpsnap.dll, softpub.dll, sort.exe, sortkey.nls, sorttbls.nls, sound.drv, spcmdcon.sys, spoolss.dll, spoolsv.exe, sprestrt.exe, sqlsodbc.hlp, sqlsrv32.dll, sqlstr.dll, sqlwid.dll, sqlwoa.dll, srvsvc.dll, ss3dfo.scr, ssbezier.scr, ssflwbox.scr, ssmarque.scr, ssmaze.scr, ssmyst.scr, sspipes.scr, ssstars.scr, sstext3d.scr, stdole2.tlb, stdole32.tlb, sti.dll, sti_ci.dll, sticpl.cpl, stimon.exe, stisvc.exe, stobject.dll, storage.dll, streamci.dll, strmdll.dll, subroutn.inf, subst.exe, svchost.exe, 
svcpack.dll, syncapp.exe,

synceng.dll, syncui.dll, sysdm.cpl, sysedit.exe, sysinv.dll, syskey.exe, sysmon.ocx, sysocmgr.exe, sysprint.sep, sysprtj.sep, syssetup.dll, system.drv, systray.exe, t2embed.dll, tapi.dll, tapi3.dll, tapi32.dll, tapiperf.dll, tapisrv.dll, tapiui.dll, taskman.exe, taskmgr.exe, tcmsetup.exe, tcpmib.dll, tcpmon.dll, tcpmon.ini, tcpmonui.dll, tcpsvcs.exe, tdc.ocx, telephon.cpl, telnet.exe, termcap, termmgr.dll, tftp.exe, themes.exe, thumbvw.dll, timedate.cpl, timer.drv, tlntadmn.exe, tlntsess.exe, tlntsvr.exe, tlntsvrp.dll, toolhelp.dll, tracert.exe, traffic.dll, tree.com, trkwks.dll, tsbyuv.dll, tsd32.dll, tssoft32.acm, typelib.dll, ufat.dll, ulib.dll, umandlg.dll, umdmxfrm.dll, umpnpmgr.dll, unicode.nls, unimdm.tsp, unimdmat.dll, uniplat.dll, unlodctr.exe, untfs.dll, ups.exe, ureg.dll, url.dll, urlmon.dll, usbmon.dll, user.exe, user32.dll, userenv.dll, userinit.exe, usp10.dll, utildll.dll, utilman.exe, v7vga.rom, vbajet32.dll, vbisurf.ax, vbscript.dll, vcdex.dll, vdmdbg.dll, vdmredir.dll, ver.dll, verifier.exe, version.dll, vfpodbc.dll, vga.dll, vga.drv, view channels.scf, vjoy.dll, vmhelper.dll, vwipxspx.dll, vwipxspx.exe, w32time.dll, w32tm.exe, w32topl.dll, w95upgnt.dll, wavemsp.dll, wbcache.deu, wbcache.enu, wbcache.esn, wbcache.fra, wbcache.ita, wbcache.nld, wbcache.sve, wbdbase.deu, wbdbase.enu, wbdbase.esn, wbdbase.fra, wbdbase.ita, wbdbase.nld, wbdbase.sve, wbem, wbemlmof, wdl.trm, webcheck.dll, 


\begin{tabular}{|c|c|c|}
\hline $\begin{array}{l}\text { webfldrs.msi, webhits.dll, } \\
\text { webvw.dll, wextract.exe, } \\
\text { wfwnet.drv, wifeman.dll, win.com, } \\
\text { win32k.sys, win32spl.dll, } \\
\text { win87em.dll, winfax.dll, } \\
\text { winhelp.hlp, winhlp32.exe, } \\
\text { wininet.dll, winlogon.exe, } \\
\text { winmm.dll, winmsd.exe, winnls.dll, } \\
\text { winoldap.mod, winrnr.dll, } \\
\text { winscard.dll, winsmon.dll, } \\
\text { winsock.dll, winspool.drv, } \\
\text { winspool.exe, winsrv.dll, winsta.dll, } \\
\text { winstrm.dll, wintrust.dll, } \\
\text { winver.exe, wjview.exe, wkssvc.dll, } \\
\text { wldap32.dll, wlnotify.dll, wmi.dll, } \\
\text { wmicore.dll, wmimgmt.msc, } \\
\text { wow32.dll, wow64.dll, } \\
\text { wow64cpu.dll, wowdeb.exe, } \\
\text { wowexec.exe, wowfax.dll, } \\
\text { wowfaxui.dll, wpnpinst.exe, } \\
\text { ws2 32.dll, ws2help.dll, } \\
\text { wscript.exe, wsecedit.dll, } \\
\text { wshatm.dll, wshext.dll, wshirda.dll, } \\
\text { wshisn.dll, wshnetbs.dll, } \\
\text { wshom.ocx, wshtcpip.dll, } \\
\text { wsnmp32.dll, wsock32.dll, } \\
\text { wtsapi32.dll, wupdinfo.dll, } \\
\text { wupdmgr.exe, xactsrv.dll, } \\
\text { xcopy.exe, xenroll.dll }\end{array}$ & & \\
\hline \%SystemDirectory\%lappmgm & Inherit from parent & Inherit from parent \\
\hline \%SystemDirectory\%lcatroot & $\begin{array}{l}\text { Users: Read and Execute } \\
\text { (folder, subfolders, and } \\
\text { files) } \\
\text { Power Users: Read and } \\
\text { Execute (folder, } \\
\text { subfolders, and files) } \\
\text { Power Users: Modify } \\
\text { (folder sad subfolder) } \\
\text { Administrators: Full } \\
\text { Control (folder, subfolder, } \\
\text { and files) } \\
\text { SYSTEM: Full Control } \\
\text { (folder, subfolder, and } \\
\text { files) } \\
\text { CREATOR OWNER: } \\
\text { Full Control (folder, }\end{array}$ & $\begin{array}{l}\text { Users: Read and Execute } \\
\text { (folder, subfolders, and } \\
\text { files) } \\
\text { Power Users: Read and } \\
\text { Execute (folder, } \\
\text { subfolders, and files) } \\
\text { Power Users: Modify } \\
\text { (folder sad subfolder) } \\
\text { Administrators: Full } \\
\text { Control (folder, subfolder, } \\
\text { and files) } \\
\text { SYSTEM: Full Control } \\
\text { (folder, subfolder, and } \\
\text { files) } \\
\text { CREATOR OWNER: } \\
\text { Full Control (folder, } \\
\end{array}$ \\
\hline
\end{tabular}




\begin{tabular}{|c|c|c|}
\hline & subfolder, and files) & subfolder, and files) \\
\hline \%SystemDirectory\%lconfig & $\begin{array}{l}\text { Users: Read and Execute } \\
\text { (folder and subfolders) } \\
\text { Power Users: Read and } \\
\text { Execute (folder and } \\
\text { subfolders) } \\
\text { Administrators: Full } \\
\text { Control (folder, subfolder, } \\
\text { and files) } \\
\text { SYSTEM: Full Control } \\
\text { (folder, subfolder, and } \\
\text { files) } \\
\text { CREATOR OWNER: } \\
\text { Full Control (folder, } \\
\text { subfolder, and files) } \\
\end{array}$ & $\begin{array}{l}\text { Users: Read and Execute } \\
\text { (folder and subfolders) } \\
\text { Power Users: Read and } \\
\text { Execute (folder and } \\
\text { subfolders) } \\
\text { Administrators: Full } \\
\text { Control (folder, subfolder, } \\
\text { and files) } \\
\text { SYSTEM: Full Control } \\
\text { (folder, subfolder, and } \\
\text { files) } \\
\text { CREATOR OWNER: } \\
\text { Full Control (folder, } \\
\text { subfolder, and files) } \\
\end{array}$ \\
\hline \%SystemDirectory\%ldhcp & $\begin{array}{l}\text { Users: Read and Execute } \\
\text { (folder, subfolders, and } \\
\text { files) } \\
\text { Power Users: Read and } \\
\text { Execute (folder, } \\
\text { subfolders, and files) } \\
\text { Administrators: Full } \\
\text { Control (folder, subfolder, } \\
\text { and files) } \\
\text { SYSTEM: Full Control } \\
\text { (folder, subfolder, and } \\
\text { files) } \\
\text { CREATOR OWNER: } \\
\text { Full Control (folder, } \\
\text { subfolder, and files) }\end{array}$ & $\begin{array}{l}\text { Users: Read and Execute } \\
\text { (folder, subfolders, and } \\
\text { files) } \\
\text { Power Users: Read and } \\
\text { Execute (folder, } \\
\text { subfolders, and files) } \\
\text { Administrators: Full } \\
\text { Control (folder, subfolder, } \\
\text { and files) } \\
\text { SYSTEM: Full Control } \\
\text { (folder, subfolder, and } \\
\text { files) } \\
\text { CREATOR OWNER: } \\
\text { Full Control (folder, } \\
\text { subfolder, and files) } \\
\end{array}$ \\
\hline \%SystemDirectory\%ldllcache & $\begin{array}{l}\text { Administrators: Full } \\
\text { Control (folder, subfolder, } \\
\text { and files) } \\
\text { SYSTEM: Full Control } \\
\text { (folder, subfolder, and } \\
\text { files) } \\
\text { CREATOR OWNER: } \\
\text { Full Control (folder, } \\
\text { subfolder, and files) }\end{array}$ & $\begin{array}{l}\text { Administrators: Full } \\
\text { Control (folder, subfolder, } \\
\text { and files) } \\
\text { SYSTEM: Full Control } \\
\text { (folder, subfolder, and } \\
\text { files) } \\
\text { CREATOR OWNER: } \\
\text { Full Control (folder, } \\
\text { subfolder, and files) }\end{array}$ \\
\hline \%SystemDirectory\%ldrivers & $\begin{array}{l}\text { Users: Read and Execute } \\
\text { (folder, subfolders, and } \\
\text { files) } \\
\text { Power Users: Read and } \\
\text { Execute (folder, } \\
\text { subfolders, and files) } \\
\text { Administrators: Full }\end{array}$ & $\begin{array}{l}\text { Users: Read and Execute } \\
\text { (folder, subfolders, and } \\
\text { files) } \\
\text { Power Users: Read and } \\
\text { Execute (folder, } \\
\text { subfolders, and files) } \\
\text { Administrators: Full }\end{array}$ \\
\hline
\end{tabular}




\begin{tabular}{|c|c|c|}
\hline & $\begin{array}{l}\text { Control (folder, subfolder, } \\
\text { and files) } \\
\text { SYSTEM: Full Control } \\
\text { (folder, subfolder, and } \\
\text { files) } \\
\text { CREATOR OWNER: } \\
\text { Full Control (folder, } \\
\text { subfolder, and files) }\end{array}$ & $\begin{array}{l}\text { Control (folder, subfolder, } \\
\text { and files) } \\
\text { SYSTEM: Full Control } \\
\text { (folder, subfolder, and } \\
\text { files) } \\
\text { CREATOR OWNER: } \\
\text { Full Control (folder, } \\
\text { subfolder, and files) }\end{array}$ \\
\hline \%SystemDirectory\%ldtclog & Inherit from parent & Inherit from parent \\
\hline \%SystemDirectory\%lgrouppolicy & Inherit from parent & Inherit from parent \\
\hline \%SystemDirectory\%lhal.dll & $\begin{array}{l}\text { Users: Read and Execute } \\
\text { Power Users: Read and } \\
\text { Execute } \\
\text { Administrators: Full } \\
\text { Control } \\
\text { SYSTEM: Full Control } \\
\end{array}$ & $\begin{array}{l}\text { Users: Read and Execute } \\
\text { Power Users: Read and } \\
\text { Execute } \\
\text { Administrators: Full } \\
\text { Control } \\
\text { SYSTEM: Full Control }\end{array}$ \\
\hline \%SystemDirectory\%lias & $\begin{array}{l}\text { Administrators: Full } \\
\text { Control (folder, subfolder, } \\
\text { and files) } \\
\text { SYSTEM: Full Control } \\
\text { (folder, subfolder, and } \\
\text { files) } \\
\text { CREATOR OWNER: } \\
\text { Full Control (folder, } \\
\text { subfolder, and files) } \\
\end{array}$ & $\begin{array}{l}\text { Administrators: Full } \\
\text { Control (folder, subfolder, } \\
\text { and files) } \\
\text { SYSTEM: Full Control } \\
\text { (folder, subfolder, and } \\
\text { files) } \\
\text { CREATOR OWNER: } \\
\text { Full Control (folder, } \\
\text { subfolder, and files) } \\
\end{array}$ \\
\hline \%SystemDirectory\%lmui & $\begin{array}{l}\text { Users: Read and Execute } \\
\text { (folder, subfolders, and } \\
\text { files) } \\
\text { Power Users: Read and } \\
\text { Execute (folder, } \\
\text { subfolders, and files) } \\
\text { Power Users: Modify } \\
\text { (folder sad subfolder) } \\
\text { Administrators: Full } \\
\text { Control (folder, subfolder, } \\
\text { and files) } \\
\text { SYSTEM: Full Control } \\
\text { (folder, subfolder, and } \\
\text { files) } \\
\text { CREATOR OWNER: } \\
\text { Full Control (folder, } \\
\text { subfolder, and files) }\end{array}$ & $\begin{array}{l}\text { Users: Read and Execute } \\
\text { (folder, subfolders, and } \\
\text { files) } \\
\text { Power Users: Read and } \\
\text { Execute (folder, } \\
\text { subfolders, and files) } \\
\text { Power Users: Modify } \\
\text { (folder sad subfolder) } \\
\text { Administrators: Full } \\
\text { Control (folder, subfolder, } \\
\text { and files) } \\
\text { SYSTEM: Full Control } \\
\text { (folder, subfolder, and } \\
\text { files) } \\
\text { CREATOR OWNER: } \\
\text { Full Control (folder, } \\
\text { subfolder, and files) }\end{array}$ \\
\hline \%SystemDirectory\%lntmsdata & Inherit from parent & Inherit from parent \\
\hline \%SystemDirectory\%lntoskrnl.exe & $\begin{array}{l}\text { Users: Read and Execute } \\
\text { Power Users: Read and } \\
\text { Execute }\end{array}$ & $\begin{array}{l}\text { Users: Read and Execute } \\
\text { Power Users: Read and } \\
\text { Execute }\end{array}$ \\
\hline
\end{tabular}




\begin{tabular}{|c|c|c|}
\hline & $\begin{array}{l}\text { Administrators: Full } \\
\text { Control } \\
\text { SYSTEM: Full Control }\end{array}$ & $\begin{array}{l}\text { Administrators: Full } \\
\text { Control } \\
\text { SYSTEM: Full Control }\end{array}$ \\
\hline $\begin{array}{l}\text { \%SystemDirectory\%los2\d1ll } \\
\text { doscalls.dll }\end{array}$ & $\begin{array}{l}\text { Users: Read and Execute } \\
\text { Power Users: Read and } \\
\text { Execute } \\
\text { Administrators: Full } \\
\text { Control } \\
\text { SYSTEM: Full Control } \\
\end{array}$ & $\begin{array}{l}\text { Users: Read and Execute } \\
\text { Power Users: Read and } \\
\text { Execute } \\
\text { Administrators: Full } \\
\text { Control } \\
\text { SYSTEM: Full Control } \\
\end{array}$ \\
\hline $\begin{array}{l}\text { \%SystemDirectory\%los2ldill } \\
\text { netapi.dll }\end{array}$ & $\begin{array}{l}\text { Users: Read and Execute } \\
\text { Power Users: Read and } \\
\text { Execute } \\
\text { Administrators: Full } \\
\text { Control } \\
\text { SYSTEM: Full Control }\end{array}$ & $\begin{array}{l}\text { Users: Read and Execute } \\
\text { Power Users: Read and } \\
\text { Execute } \\
\text { Administrators: Full } \\
\text { Control } \\
\text { SYSTEM: Full Control }\end{array}$ \\
\hline $\begin{array}{l}\text { \%SystemDirectory\%los } 21 \\
\text { oso001.009 }\end{array}$ & $\begin{array}{l}\text { Users: Read and Execute } \\
\text { Power Users: Read and } \\
\text { Execute } \\
\text { Administrators: Full } \\
\text { Control } \\
\text { SYSTEM: Full Control } \\
\end{array}$ & $\begin{array}{l}\text { Users: Read and Execute } \\
\text { Power Users: Read and } \\
\text { Execute } \\
\text { Administrators: Full } \\
\text { Control } \\
\text { SYSTEM: Full Control } \\
\end{array}$ \\
\hline $\begin{array}{l}\text { \%SystemDirectory\%lras } \\
\text { cis.scp, pad.inf, pppmenu.scp, } \\
\text { slip.scp, slipmenu.scp, switch.inf }\end{array}$ & $\begin{array}{l}\text { Users: Read and Execute } \\
\text { Power Users: Read and } \\
\text { Execute } \\
\text { Administrators: Full } \\
\text { Control } \\
\text { SYSTEM: Full Control }\end{array}$ & $\begin{array}{l}\text { Users: Read and Execute } \\
\text { Power Users: Read and } \\
\text { Execute } \\
\text { Administrators: Full } \\
\text { Control } \\
\text { SYSTEM: Full Control } \\
\end{array}$ \\
\hline $\begin{array}{l}\text { \%SystemDirectory\%lreinstallbacku } \\
\text { ps }\end{array}$ & $\begin{array}{l}\text { Users: Read and Execute } \\
\text { (folder, subfolders, and } \\
\text { files) } \\
\text { Power Users: Read and } \\
\text { Execute (folder, } \\
\text { subfolders, and files) } \\
\text { Power Users: Modify } \\
\text { (folder sad subfolder) } \\
\text { Administrators: Full } \\
\text { Control (folder, subfolder, } \\
\text { and files) } \\
\text { SYSTEM: Full Control } \\
\text { (folder, subfolder, and } \\
\text { files) } \\
\text { CREATOR OWNER: } \\
\text { Full Control (folder, } \\
\text { subfolder, and files) } \\
\text { * }\end{array}$ & $\begin{array}{l}\text { Users: Read and Execute } \\
\text { (folder, subfolders, and } \\
\text { files) } \\
\text { Power Users: Read and } \\
\text { Execute (folder, } \\
\text { subfolders, and files) } \\
\text { Power Users: Modify } \\
\text { (folder sad subfolder) } \\
\text { Administrators: Full } \\
\text { Control (folder, subfolder, } \\
\text { and files) } \\
\text { SYSTEM: Full Control } \\
\text { (folder, subfolder, and } \\
\text { files) } \\
\text { CREATOR OWNER: } \\
\text { Full Control (folder, } \\
\text { subfolder, and files) }\end{array}$ \\
\hline \%SystemDirectory\%lrepl & $\begin{array}{l}\text { Users: Read and Execute } \\
\text { (folder, subfolders, and }\end{array}$ & $\begin{array}{l}\text { Users: Read and Execute } \\
\text { (folder, subfolders, and }\end{array}$ \\
\hline
\end{tabular}

CIAC-2319 


\begin{tabular}{|c|c|c|}
\hline & $\begin{array}{l}\text { files) } \\
\text { Power Users: Read and } \\
\text { Execute (folder, } \\
\text { subfolders, and files) } \\
\text { Administrators: Full } \\
\text { Control (folder, subfolder, } \\
\text { and files) } \\
\text { SYSTEM: Full Control } \\
\text { (folder, subfolder, and } \\
\text { files) } \\
\text { CREATOR OWNER: } \\
\text { Full Control (folder, } \\
\text { subfolder, and files) } \\
* * * * 1\end{array}$ & $\begin{array}{l}\text { files) } \\
\text { Power Users: Read and } \\
\text { Execute (folder, } \\
\text { subfolders, and files) } \\
\text { Administrators: Full } \\
\text { Control (folder, subfolder, } \\
\text { and files) } \\
\text { SYSTEM: Full Control } \\
\text { (folder, subfolder, and } \\
\text { files) } \\
\text { CREATOR OWNER: } \\
\text { Full Control (folder, } \\
\text { subfolder, and files) }\end{array}$ \\
\hline \%SystemDirectory\%ไrepl \export & $\begin{array}{l}\text { Replicator: Modify } \\
\text { (folder, subfolders, and } \\
\text { files) }\end{array}$ & $\begin{array}{l}\text { Replicator: Modify } \\
\text { (folder, subfolders, and } \\
\text { files) } \\
\end{array}$ \\
\hline \%SystemDirectory\%lrepl $\backslash$ import & $\begin{array}{l}\text { Replicator: Modify } \\
\text { (folder, subfolders, and } \\
\text { files) }\end{array}$ & $\begin{array}{l}\text { Replicator: Modify } \\
\text { (folder, subfolders, and } \\
\text { files) }\end{array}$ \\
\hline \%SystemDirectory\%lsetup & Inherit from parent & Inherit from parent \\
\hline \%SystemDirectory\%lshellext & $\begin{array}{l}\text { Users: Read and Execute } \\
\text { (folder, subfolders, and } \\
\text { files) } \\
\text { Power Users: Read and } \\
\text { Execute (folder, } \\
\text { subfolders, and files) } \\
\text { Power Users: Modify } \\
\text { (folder sad subfolder) } \\
\text { Administrators: Full } \\
\text { Control (folder, subfolder, } \\
\text { and files) } \\
\text { SYSTEM: Full Control } \\
\text { (folder, subfolder, and } \\
\text { files) } \\
\text { CREATOR OWNER: } \\
\text { Full Control (folder, } \\
\text { subfolder, and files) }\end{array}$ & $\begin{array}{l}\text { Users: Read and Execute } \\
\text { (folder, subfolders, and } \\
\text { files) } \\
\text { Power Users: Read and } \\
\text { Execute (folder, } \\
\text { subfolders, and files) } \\
\text { Power Users: Modify } \\
\text { (folder sad subfolder) } \\
\text { Administrators: Full } \\
\text { Control (folder, subfolder, } \\
\text { and files) } \\
\text { SYSTEM: Full Control } \\
\text { (folder, subfolder, and } \\
\text { files) } \\
\text { CREATOR OWNER: } \\
\text { Full Control (folder, } \\
\text { subfolder, and files) }\end{array}$ \\
\hline \%SystemDirectory\%lspool $\backslash$ printers & $\begin{array}{l}\text { Users: Read and Execute } \\
\text { (folder and subfolder) } \\
\text { Power Users: Modify } \\
\text { (folder, subfolders, and } \\
\text { files) } \\
\text { Administrators: Full } \\
\text { Control (folder, subfolder, } \\
\text { and files) } \\
\text { SYSTEM: Full Control } \\
\end{array}$ & $\begin{array}{l}\text { Users: Read and Execute } \\
\text { (folder and subfolder) } \\
\text { Power Users: Modify } \\
\text { (folder, subfolders, and } \\
\text { files) } \\
\text { Administrators: Full } \\
\text { Control (folder, subfolder, } \\
\text { and files) } \\
\text { SYSTEM: Full Control } \\
\end{array}$ \\
\hline
\end{tabular}




\begin{tabular}{|c|c|c|}
\hline & $\begin{array}{l}\text { (folder, subfolder, and } \\
\text { files) } \\
\text { CREATOR OWNER: } \\
\text { Full Control (folder, } \\
\text { subfolder, and files) } \\
\end{array}$ & $\begin{array}{l}\text { (folder, subfolder, and } \\
\text { files) } \\
\text { CREATOR OWNER: } \\
\text { Full Control (folder, } \\
\text { subfolder, and files) }\end{array}$ \\
\hline \%SystemDirectory\%lwbem & $\begin{array}{l}\text { Users: Read and Execute } \\
\text { (folder, subfolders, and } \\
\text { files) } \\
\text { Power Users: Read and } \\
\text { Execute (folder, } \\
\text { subfolders, and files) } \\
\text { Power Users: Modify } \\
\text { (folder sad subfolder) } \\
\text { Administrators: Full } \\
\text { Control (folder, subfolder, } \\
\text { and files) } \\
\text { SYSTEM: Full Control } \\
\text { (folder, subfolder, and } \\
\text { files) } \\
\text { CREATOR OWNER: } \\
\text { Full Control (folder, } \\
\text { subfolder, and files) }\end{array}$ & $\begin{array}{l}\text { Users: Read and Execute } \\
\text { (folder, subfolders, and } \\
\text { files) } \\
\text { Power Users: Read and } \\
\text { Execute (folder, } \\
\text { subfolders, and files) } \\
\text { Power Users: Modify } \\
\text { (folder sad subfolder) } \\
\text { Administrators: Full } \\
\text { Control (folder, subfolder, } \\
\text { and files) } \\
\text { SYSTEM: Full Control } \\
\text { (folder, subfolder, and } \\
\text { files) } \\
\text { CREATOR OWNER: } \\
\text { Full Control (folder, } \\
\text { subfolder, and files) }\end{array}$ \\
\hline \%SystemDirectory\%lwbem $\backslash$ mof & $\begin{array}{l}\text { Users: Read and Execute } \\
\text { (folder, subfolders, and } \\
\text { files) } \\
\text { Power Users: Modify } \\
\text { (folder, subfolders, and } \\
\text { files) } \\
\text { Administrators: Full } \\
\text { Control (folder, subfolder, } \\
\text { and files) } \\
\text { SYSTEM: Full Control } \\
\text { (folder, subfolder, and } \\
\text { files) } \\
\text { CREATOR OWNER: } \\
\text { Full Control (folder, } \\
\text { subfolder, and files) }\end{array}$ & $\begin{array}{l}\text { Users: Read and Execute } \\
\text { (folder, subfolders, and } \\
\text { files) } \\
\text { Power Users: Modify } \\
\text { (folder, subfolders, and } \\
\text { files) } \\
\text { Administrators: Full } \\
\text { Control (folder, subfolder, } \\
\text { and files) } \\
\text { SYSTEM: Full Control } \\
\text { (folder, subfolder, and } \\
\text { files) } \\
\text { CREATOR OWNER: } \\
\text { Full Control (folder, } \\
\text { subfolder, and files) }\end{array}$ \\
\hline \%SystemRoot\%ltasks & Inherit from parent & Inherit from parent \\
\hline \%SystemRoot\%ltemp & $\begin{array}{l}\text { Users: Traverse/execute, } \\
\text { Create files, and Create } \\
\text { folders (folder and } \\
\text { subfolders) } \\
\text { Power Users: Modify } \\
\text { (folder, subfolders, and } \\
\text { files) } \\
\text { Administrators: Full } \\
\end{array}$ & $\begin{array}{l}\text { Users: Traverse/execute, } \\
\text { Create files, and Create } \\
\text { folders (folder and } \\
\text { subfolders) } \\
\text { Power Users: Modify } \\
\text { (folder, subfolders, and } \\
\text { files) } \\
\text { Administrators: Full }\end{array}$ \\
\hline
\end{tabular}




\begin{tabular}{|c|c|c|}
\hline & $\begin{array}{l}\text { Control (folder, subfolder, } \\
\text { and files) } \\
\text { SYSTEM: Full Control } \\
\text { (folder, subfolder, and } \\
\text { files) } \\
\text { CREATOR OWNER: } \\
\text { Full Control (folder, } \\
\text { subfolder, and files) } \\
\end{array}$ & $\begin{array}{l}\text { Control (folder, subfolder, } \\
\text { and files) } \\
\text { SYSTEM: Full Control } \\
\text { (folder, subfolder, and } \\
\text { files) } \\
\text { CREATOR OWNER: } \\
\text { Full Control (folder, } \\
\text { subfolder, and files) } \\
\end{array}$ \\
\hline \%SystemRoot\%ltwain.dll & $\begin{array}{l}\text { Users: Read and Execute } \\
\text { Power Users: Read and } \\
\text { Execute } \\
\text { Administrators: Full } \\
\text { Control } \\
\text { SYSTEM: Full Control }\end{array}$ & $\begin{array}{l}\text { Users: Read and Execute } \\
\text { Power Users: Read and } \\
\text { Execute } \\
\text { Administrators: Full } \\
\text { Control } \\
\text { SYSTEM: Full Control }\end{array}$ \\
\hline \%SystemRoot\%ltwain_32 & $\begin{array}{l}\text { Users: Read and Execute } \\
\text { (folder, subfolders, and } \\
\text { files) } \\
\text { Power Users: Read and } \\
\text { Execute (folder, } \\
\text { subfolders, and files) } \\
\text { Power Users: Modify } \\
\text { (folder sad subfolder) } \\
\text { Administrators: Full } \\
\text { Control (folder, subfolder, } \\
\text { and files) } \\
\text { SYSTEM: Full Control } \\
\text { (folder, subfolder, and } \\
\text { files) } \\
\text { CREATOR OWNER: } \\
\text { Full Control (folder, } \\
\text { subfolder, and files) }\end{array}$ & $\begin{array}{l}\text { Users: Read and Execute } \\
\text { (folder, subfolders, and } \\
\text { files) } \\
\text { Power Users: Read and } \\
\text { Execute (folder, } \\
\text { subfolders, and files) } \\
\text { Power Users: Modify } \\
\text { (folder sad subfolder) } \\
\text { Administrators: Full } \\
\text { Control (folder, subfolder, } \\
\text { and files) } \\
\text { SYSTEM: Full Control } \\
\text { (folder, subfolder, and } \\
\text { files) } \\
\text { CREATOR OWNER: } \\
\text { Full Control (folder, } \\
\text { subfolder, and files) }\end{array}$ \\
\hline \%SystemRoot\%ltwain_32.dll & $\begin{array}{l}\text { Users: Read and Execute } \\
\text { Power Users: Read and } \\
\text { Execute } \\
\text { Administrators: Full } \\
\text { Control } \\
\text { SYSTEM: Full Control }\end{array}$ & $\begin{array}{l}\text { Users: Read and Execute } \\
\text { (folder, subfolders, and } \\
\text { files) } \\
\text { Power Users: Read and } \\
\text { Execute (folder, } \\
\text { subfolders, and files) } \\
\text { Power Users: Modify } \\
\text { (folder sad subfolder) } \\
\text { Administrators: Full } \\
\text { Control (folder, subfolder, } \\
\text { and files) } \\
\text { SYSTEM: Full Control } \\
\text { (folder, subfolder, and } \\
\text { files) } \\
\text { CREATOR OWNER: }\end{array}$ \\
\hline
\end{tabular}




\begin{tabular}{|c|c|c|}
\hline & & $\begin{array}{l}\text { Full Control (folder, } \\
\text { subfolder, and files) }\end{array}$ \\
\hline \%SystemRoot\%ltwunk_16.exe & $\begin{array}{l}\text { Users: Read and Execute } \\
\text { Power Users: Read and } \\
\text { Execute } \\
\text { Administrators: Full } \\
\text { Control } \\
\text { SYSTEM: Full Control }\end{array}$ & $\begin{array}{l}\text { Users: Read and Execute } \\
\text { Power Users: Read and } \\
\text { Execute } \\
\text { Administrators: Full } \\
\text { Control } \\
\text { SYSTEM: Full Control }\end{array}$ \\
\hline \%SystemRoot\%ltwunk_32.exe & $\begin{array}{l}\text { Users: Read and Execute } \\
\text { Power Users: Read and } \\
\text { Execute } \\
\text { Administrators: Full } \\
\text { Control } \\
\text { SYSTEM: Full Control } \\
\end{array}$ & $\begin{array}{l}\text { Users: Read and Execute } \\
\text { Power Users: Read and } \\
\text { Execute } \\
\text { Administrators: Full } \\
\text { Control } \\
\text { SYSTEM: Full Control } \\
\end{array}$ \\
\hline \%SystemRoot\%lupwizun.exe & $\begin{array}{l}\text { Users: Read and Execute } \\
\text { Power Users: Read and } \\
\text { Execute } \\
\text { Administrators: Full } \\
\text { Control } \\
\text { SYSTEM: Full Control }\end{array}$ & $\begin{array}{l}\text { Users: Read and Execute } \\
\text { Power Users: Read and } \\
\text { Execute } \\
\text { Administrators: Full } \\
\text { Control } \\
\text { SYSTEM: Full Control }\end{array}$ \\
\hline \%SystemRoot\%lvmmreg32.dll & $\begin{array}{l}\text { Users: Read and Execute } \\
\text { Power Users: Read and } \\
\text { Execute } \\
\text { Administrators: Full } \\
\text { Control } \\
\text { SYSTEM: Full Control }\end{array}$ & $\begin{array}{l}\text { Users: Read and Execute } \\
\text { Power Users: Read and } \\
\text { Execute } \\
\text { Administrators: Full } \\
\text { Control } \\
\text { SYSTEM: Full Control }\end{array}$ \\
\hline \%SystemRoot\%lweb & $\begin{array}{l}\text { Users: Read and Execute } \\
\text { (folder, subfolders, and } \\
\text { files) } \\
\text { Power Users: Read and } \\
\text { Execute (folder, } \\
\text { subfolders, and files) } \\
\text { Power Users: Modify } \\
\text { (folder sad subfolder) } \\
\text { Administrators: Full } \\
\text { Control (folder, subfolder, } \\
\text { and files) } \\
\text { SYSTEM: Full Control } \\
\text { (folder, subfolder, and } \\
\text { files) } \\
\text { CREATOR OWNER: } \\
\text { Full Control (folder, } \\
\text { subfolder, and files) }\end{array}$ & $\begin{array}{l}\text { Users: Read and Execute } \\
\text { (folder, subfolders, and } \\
\text { files) } \\
\text { Power Users: Read and } \\
\text { Execute (folder, } \\
\text { subfolders, and files) } \\
\text { Power Users: Modify } \\
\text { (folder sad subfolder) } \\
\text { Administrators: Full } \\
\text { Control (folder, subfolder, } \\
\text { and files) } \\
\text { SYSTEM: Full Control } \\
\text { (folder, subfolder, and } \\
\text { files) } \\
\text { CREATOR OWNER: } \\
\text { Full Control (folder, } \\
\text { subfolder, and files) }\end{array}$ \\
\hline \%SystemRoot\%lwelcome.exe & $\begin{array}{l}\text { Users: Read and Execute } \\
\text { Power Users: Read and } \\
\text { Execute }\end{array}$ & \\
\hline
\end{tabular}




\begin{tabular}{|c|c|c|}
\hline & $\begin{array}{l}\text { Administrators: Full } \\
\text { Control } \\
\text { SYSTEM: Full Control }\end{array}$ & \\
\hline \%SystemRoot\%lwelcome.ini & $\begin{array}{l}\text { Users: Read and Execute } \\
\text { Power Users: Read and } \\
\text { Execute } \\
\text { Administrators: Full } \\
\text { Control } \\
\text { SYSTEM: Full Control }\end{array}$ & \\
\hline \%SystemRoot\%lwinhelp.exe & $\begin{array}{l}\text { Users: Read and Execute } \\
\text { Power Users: Read and } \\
\text { Execute } \\
\text { Administrators: Full } \\
\text { Control } \\
\text { SYSTEM: Full Control }\end{array}$ & $\begin{array}{l}\text { Users: Read and Execute } \\
\text { Power Users: Read and } \\
\text { Execute } \\
\text { Administrators: Full } \\
\text { Control } \\
\text { SYSTEM: Full Control }\end{array}$ \\
\hline \%SystemRoot\%lwinhlp32.exe & $\begin{array}{l}\text { Users: Read and Execute } \\
\text { Power Users: Read and } \\
\text { Execute } \\
\text { Administrators: Full } \\
\text { Control } \\
\text { SYSTEM: Full Control }\end{array}$ & $\begin{array}{l}\text { Users: Read and Execute } \\
\text { Power Users: Read and } \\
\text { Execute } \\
\text { Administrators: Full } \\
\text { Control } \\
\text { SYSTEM: Full Control }\end{array}$ \\
\hline \%SystemRoot\%lwinnt.bmp & $\begin{array}{l}\text { Users: Read and Execute } \\
\text { Power Users: Read and } \\
\text { Execute } \\
\text { Administrators: Full } \\
\text { Control } \\
\text { SYSTEM: Full Control } \\
\end{array}$ & \\
\hline \%SystemRoot\%lwinnt256.bmp & $\begin{array}{l}\text { Users: Read and Execute } \\
\text { Power Users: Read and } \\
\text { Execute } \\
\text { Administrators: Full } \\
\text { Control } \\
\text { SYSTEM: Full Control }\end{array}$ & \\
\hline \%SystemRoot\%lwinrep.exe & $\begin{array}{l}\text { Users: Read and Execute } \\
\text { Power Users: Read and } \\
\text { Execute } \\
\text { Administrators: Full } \\
\text { Control } \\
\text { SYSTEM: Full Control }\end{array}$ & $\begin{array}{l}\text { Users: Read and Execute } \\
\text { Power Users: Read and } \\
\text { Execute } \\
\text { Administrators: Full } \\
\text { Control } \\
\text { SYSTEM: Full Control }\end{array}$ \\
\hline
\end{tabular}




\section{APPENDIX F - Group POLICY SETTINGS VS. REgISTRY KeYS}

This table is a cross reference between the Group Policy settings and the Windows 2000 registry keys that are changed by the policy setting. Here, HKLM $=$ HKEY_LOCAL_MACHINE and HKCU $=$ HKEY_CURRENT_USER.

\begin{tabular}{|c|c|}
\hline Group Polıcy & Registry entry \\
\hline Action on server disconnect (Computer) & $\begin{array}{l}\text { Name: GoOfflineAction } \\
\text { Key: HKLM\Software\Policies\Microsoft\Windows \NetCache }\end{array}$ \\
\hline Action on server disconnect (User) & $\begin{array}{l}\text { Name: GoOfflineAction } \\
\text { Key: HKCU\Software\Policies\Microsoft\Windows \NetCache }\end{array}$ \\
\hline Active Desktop Wallpaper & 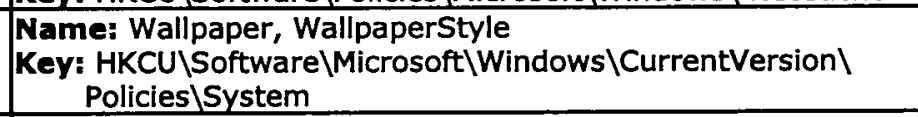 \\
\hline $\begin{array}{l}\text { Add "Run in Separate Memory Space" } \\
\text { check box to Run dialog box }\end{array}$ & 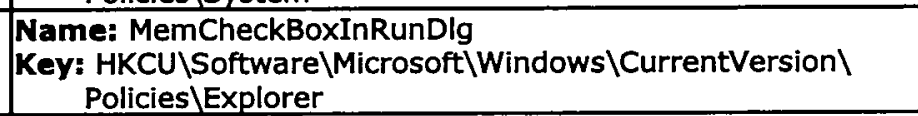 \\
\hline Add Logoff to the Start Menu & $\begin{array}{l}\begin{array}{l}\text { Name: ForceStartMenuLogOff } \\
\text { Key: HKCU\Software\Microsoft } \backslash \text { Windows } \backslash \text { CurrentVersion } \backslash \\
\text { Policies } \backslash \text { Explorer }\end{array} \\
\end{array}$ \\
\hline Add/Delete items & 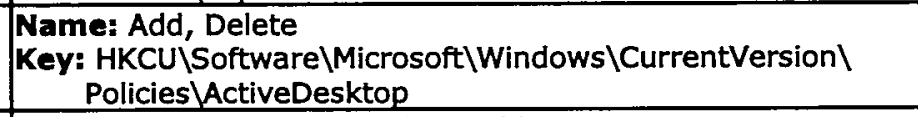 \\
\hline $\begin{array}{l}\text { Administratively assigned offline files } \\
\text { (Computer) }\end{array}$ & \begin{tabular}{|c|}
$\begin{array}{l}\text { Name: AssignedOfflineFolders subkey } \\
\text { Key: HKLM\Software\Policies\Microsoft } \backslash \text { Windows } \backslash \\
\text { NetCache\AssignedOfflineFolders }\end{array}$ \\
\end{tabular} \\
\hline $\begin{array}{l}\text { Administratively assigned offline files } \\
\text { (User) }\end{array}$ & 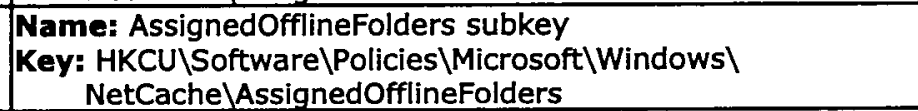 \\
\hline $\begin{array}{l}\text { Allow access to current user's RAS } \\
\text { connection properties }\end{array}$ & 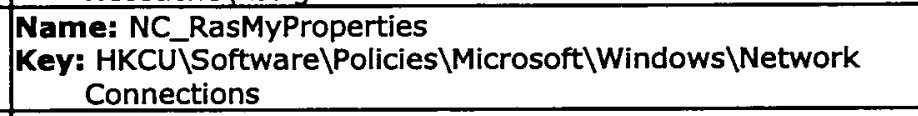 \\
\hline $\begin{array}{l}\text { Allow admin to install from Terminal } \\
\text { Services session }\end{array}$ & $\begin{array}{l}\text { Name: EnableAdminTSRemote } \\
\text { Key: HKLM\Software\Policies\Microsoft)Windows\Installer }\end{array}$ \\
\hline $\begin{array}{l}\text { Allow configuration of connection sharing } \\
\text { (Computer) }\end{array}$ & $\begin{array}{l}\text { Name: NC_ShowSharedAccessUI } \\
\text { Key: HKLM\Software\Policies\Microsoft } \backslash \text { Windows } \backslash \text { Network } \\
\text { Connections }\end{array}$ \\
\hline $\begin{array}{l}\text { Allow configuration of connection sharing } \\
\text { (User) }\end{array}$ & 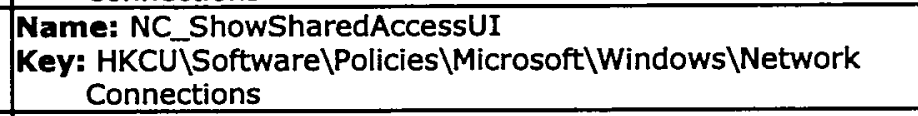 \\
\hline $\begin{array}{l}\text { Allow connection components to be } \\
\text { enabled or disabled }\end{array}$ & $\begin{array}{l}\text { Name: NC_ChangeBindState } \\
\text { Key: HKCU\Software } \backslash \text { Policies } \backslash \text { Microsoft } \backslash \text { Windows } \backslash \text { Network } \\
\text { Connections }\end{array}$ \\
\hline Allow only bitmapped wallpaper & 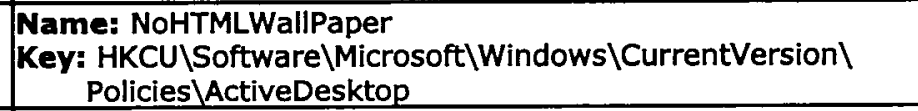 \\
\hline Allow printers to be published & $\begin{array}{l}\text { Name: PublishPrinters } \\
\text { Key: HKLM\Software)Policies\Microsoft|Windows NT } \text { Printers }\end{array}$ \\
\hline Allow pruning of published printers & $\begin{array}{l}\text { Name: Immortal } \\
\text { Key: HKLM\Software\Policies\Microsoft/Windows NT Printers }\end{array}$ \\
\hline Allow TCP/IP advanced configuration & 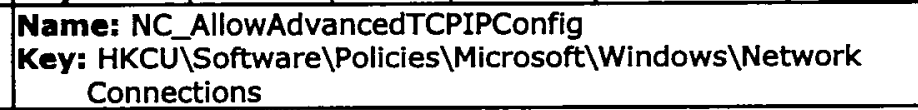 \\
\hline $\begin{array}{l}\text { Always install with elevated privileges } \\
\text { (Computer) }\end{array}$ & 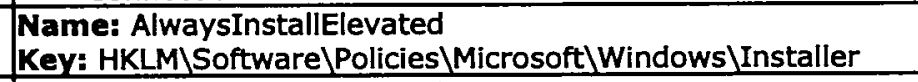 \\
\hline $\begin{array}{l}\text { Always install with elevated privileges } \\
\text { (User) }\end{array}$ & $\begin{array}{l}\text { Name: AlwaysInstallElevated } \\
\text { Key: HKCU\Software\Policies\Microsoft\Windows)Installer }\end{array}$ \\
\hline $\begin{array}{l}\text { Apply group policy for computers } \\
\text { asynchronously during startup }\end{array}$ & $\begin{array}{l}\text { Name: SynchronousMachineGroupPolicy } \\
\text { Key: HKLM\Software\Microsoft } \backslash \text { Windows } \backslash \text { CurrentVersion } \backslash \\
\text { Policies } \backslash S y s t e m\end{array}$ \\
\hline
\end{tabular}




\begin{tabular}{|c|c|}
\hline $\begin{array}{l}\text { Apply group policy for users } \\
\text { asynchronously during logon }\end{array}$ & $\begin{array}{l}\text { Name: SynchronousUserGroupPolicy } \\
\text { Key: HKLM\Software } \backslash \text { Microsoft } \backslash \text { Windows } \backslash \text { CurrentVersion } \backslash \\
\text { Policies } \backslash \text { System }\end{array}$ \\
\hline Apply policy to removable media & \begin{tabular}{|l}
$\begin{array}{l}\text { Name: ApplyToRemovableMedia } \\
\text { Key: HKLM\Software\Policies\Microsoft } \backslash \text { Windows NT } \\
\text { DiskQuota }\end{array}$ \\
\end{tabular} \\
\hline $\begin{array}{l}\text { At logoff, delete local copy of user's offline } \\
\text { files }\end{array}$ & $\begin{array}{l}\text { Name: PurgeAtLogoff } \\
\text { Key: HKLM\Software\Policies\Microsoft\Windows\NetCache }\end{array}$ \\
\hline $\begin{array}{l}\text { Automatically publish new printers in } \\
\text { Active Directory }\end{array}$ & \begin{tabular}{|l}
$\begin{array}{l}\text { Name: Auto Publishing } \\
\text { Key: HKLM\Software\Policies } \backslash \text { Microsoft } \backslash \text { Windows NT } \\
\text { Printers } \backslash \text { Wizard }\end{array}$ \\
\end{tabular} \\
\hline Browse a common web site to find printers & 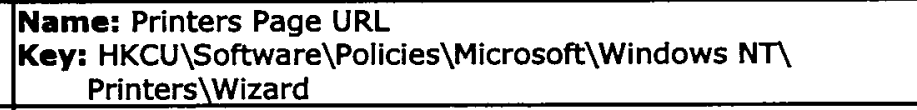 \\
\hline Browse the network to find printers & 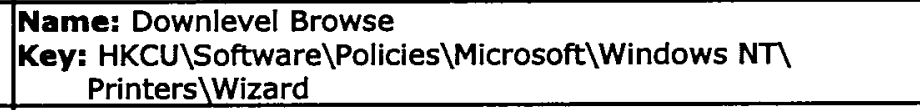 \\
\hline $\begin{array}{l}\text { Cache transforms in secure location on } \\
\text { workstation }\end{array}$ & 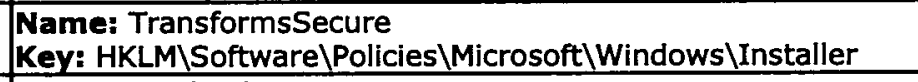 \\
\hline Century interpretation for Year 2000 & 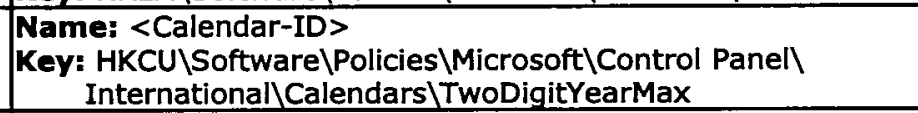 \\
\hline Check published state & $\begin{array}{l}\text { Name: VerifyPublishedState } \\
\text { Key: HKLM\Software\Policies\Microsoft|Windows NT Printers }\end{array}$ \\
\hline $\begin{array}{l}\text { Clear history of recently opened } \\
\text { documents on exit }\end{array}$ & 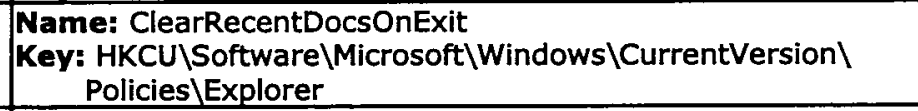 \\
\hline Code signing for device drivers & 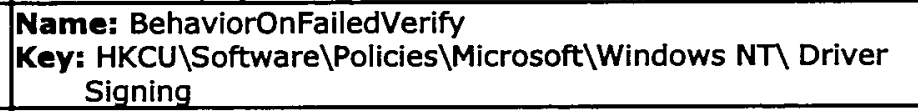 \\
\hline Computer Iocation & 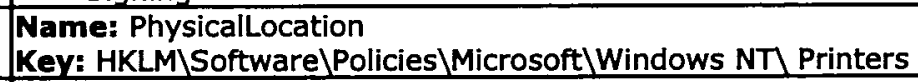 \\
\hline $\begin{array}{l}\text { Connect home directory to root of the } \\
\text { share }\end{array}$ & 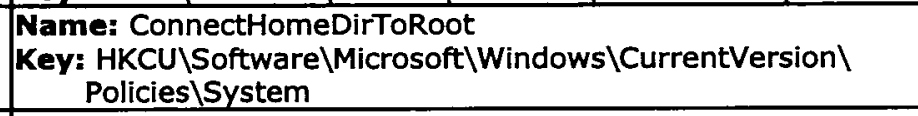 \\
\hline $\begin{array}{l}\text { Create new Group Policy Object links } \\
\text { disabled by default }\end{array}$ & 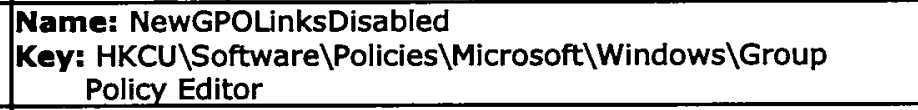 \\
\hline $\begin{array}{l}\text { Custom support URL in the Printers } \\
\text { folder's left pane }\end{array}$ & $\begin{array}{l}\text { Name: SupportLink, SupportLinkName } \\
\text { Key: HKLM)Software/Policies\Microsoft|Windows NT/ Printers }\end{array}$ \\
\hline Custom user interface & 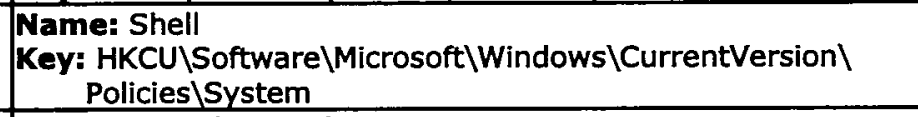 \\
\hline $\begin{array}{l}\text { Default Active Directory path when } \\
\text { searching for printers }\end{array}$ & 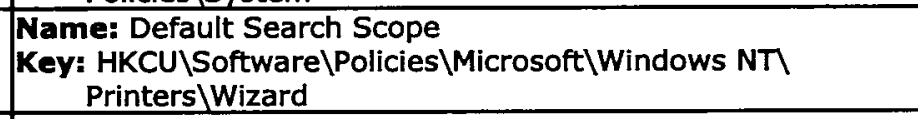 \\
\hline Default cache size & 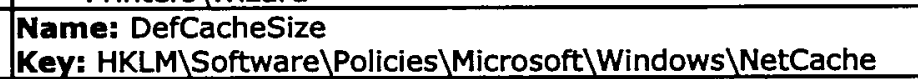 \\
\hline Default quota limit and warning level & $\begin{array}{l}\text { Name: Limit, LimitUnits, Threshold, ThresholdUnits } \\
\text { Key: HKLM\Software\Policies\Microsoft\Windows NT } \\
\text { DiskQuota }\end{array}$ \\
\hline Delete cached copies of roaming profiles & \begin{tabular}{|l|}
$\begin{array}{l}\text { Name: DeleteRoamingCache } \\
\text { Key: HKLM } \backslash \text { Software } \backslash \text { Microsoft } \backslash \text { Windows } \backslash \text { CurrentVersion } \backslash \\
\text { Policies } \backslash \text { System }\end{array}$ \\
\end{tabular} \\
\hline Directory pruning interval & $\begin{array}{l}\text { Name: PruningInterval } \\
\text { Key: HKLM\Software\Policies\Microsoft/Windows NT } \text { Printers }\end{array}$ \\
\hline Directory pruning priority & $\begin{array}{l}\text { Name: PruningPriority } \\
\text { Key: HKLM/Software/Policies\Microsoft|Windows NT \ Printers }\end{array}$ \\
\hline Directory pruning retry & $\begin{array}{l}\text { Name: PruningRetries } \\
\text { Key: HKLMISoftware\Policies\Microsoft\Windows NT\ Printers }\end{array}$ \\
\hline $\begin{array}{l}\text { Disable "Make Available Offline" } \\
\text { (Computer) }\end{array}$ & $\begin{array}{l}\text { Name: NoMakeAvailableOffline } \\
\text { Key: HKLM)Software\Policies/Microsoft|Windows\NetCache }\end{array}$ \\
\hline Disable "Make Available Offline" (User) & $\begin{array}{l}\text { Name: NoMakeAvailableOffline } \\
\text { Key: HKCU\Software\Policies\Microsoft|Windows\ NetCache }\end{array}$ \\
\hline
\end{tabular}




\begin{tabular}{|c|c|}
\hline Disable Active Desktop & \begin{tabular}{|l}
$\begin{array}{l}\text { Name: NoActiveDesktop } \\
\text { Key: HKCU\Software\Microsoft } \backslash \text { Windows } \backslash \text { CurrentVersion } \backslash \\
\text { Policies\Explorer }\end{array}$ \\
\end{tabular} \\
\hline Disable Add/Remove Programs & 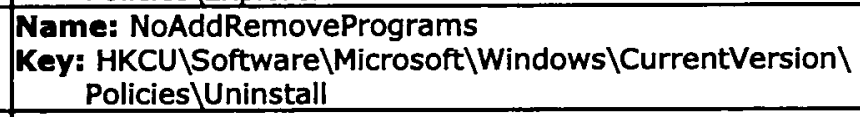 \\
\hline $\begin{array}{l}\text { Disable adding, dragging, dropping and } \\
\text { closing the Taskbar's toolbars }\end{array}$ & 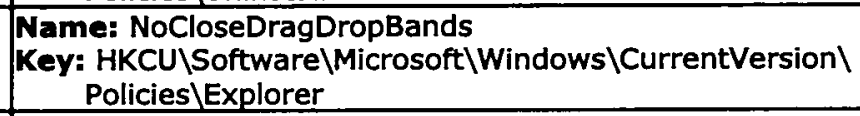 \\
\hline Disable addition of printers & 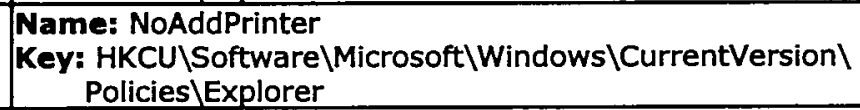 \\
\hline Disable adjusting desktop toolbars & 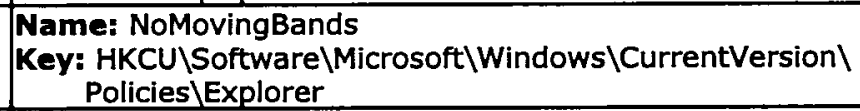 \\
\hline Disable Advanced Menu (Computer) & 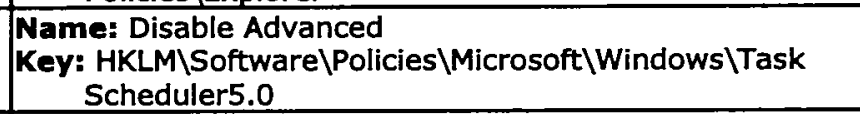 \\
\hline Disable Advanced Menu (User) & $\begin{array}{l}\text { Name: Disable Advanced } \\
\text { Key: HKCU\Software\Policies\Microsoft } \backslash \text { Windows } \backslash \text { Task } \\
\text { Scheduler5.0 }\end{array}$ \\
\hline Disable all items & 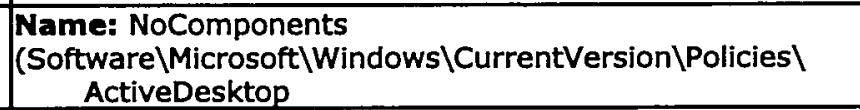 \\
\hline $\begin{array}{l}\text { Disable and remove links to Windows } \\
\text { Update }\end{array}$ & $\begin{array}{l}\begin{array}{l}\text { Name: NoWindowsUpdate } \\
\text { Key: HKCU\SoftwarelMicrosoft } \backslash \text { Windows } \backslash \text { CurrentVersion } \backslash \\
\text { Policies } \backslash \text { Explorer }\end{array} \\
\end{array}$ \\
\hline $\begin{array}{l}\text { Disable and remove the Shut Down } \\
\text { command }\end{array}$ & 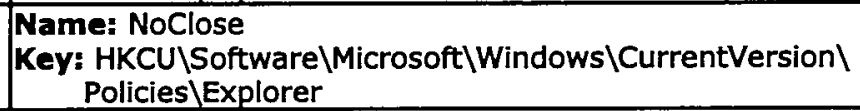 \\
\hline Disable automatic update of ADM files & 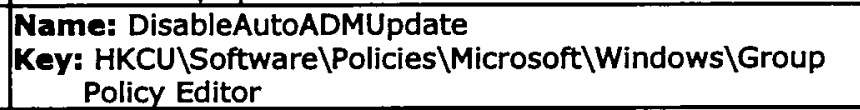 \\
\hline Disable Autoplay (Computer) & $\begin{array}{l}\text { Name: NoDriveTypeAutoRun } \\
\text { Key: HKLM\Software\Microsoft } \backslash W i n d o w s \backslash \text { CurrentVersion } \backslash \\
\text { Policies } \backslash \text { Explorer }\end{array}$ \\
\hline Disable Autoplay (User) & 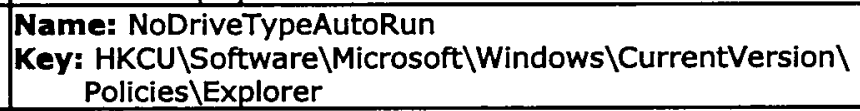 \\
\hline Disable background refresh of group policy & 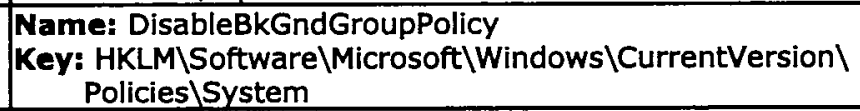 \\
\hline $\begin{array}{l}\text { Disable Boot / Shutdown / Logon / Logoff } \\
\text { status messages }\end{array}$ & $\begin{array}{l}\text { Name: DisableStatusMessages } \\
\text { Key: HKLM } \backslash \text { Software } \backslash \text { Microsoft } \backslash W i n d o w s \backslash \text { CurrentVersion } \backslash \\
\text { Policies } \backslash \text { System }\end{array}$ \\
\hline Disable browse dialog box for new source & $\begin{array}{l}\text { Name: DisableBrowse } \\
\text { Key: HKLM\Software\Policies\Microsoft \Windows\Installer }\end{array}$ \\
\hline Disable Change Password & 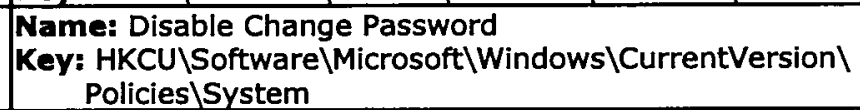 \\
\hline $\begin{array}{l}\text { Disable changes to Taskbar and Start Menu } \\
\text { Settings }\end{array}$ & 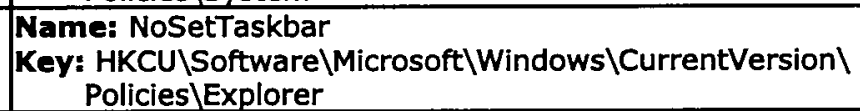 \\
\hline Disable changing wallpaper & $\begin{array}{l}\text { Name: NoChangingWal|Paper } \\
\text { Key: HKCU\Software\Microsoft } \backslash \text { Windows } \backslash \text { CurrentVersion } \backslash \\
\text { Policies\ActiveDesktop }\end{array}$ \\
\hline Disable context menu for taskbar & 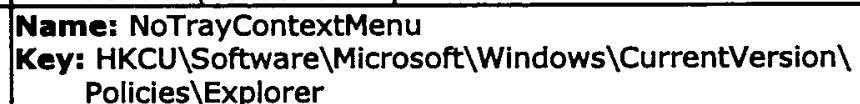 \\
\hline Disable Control Panel & 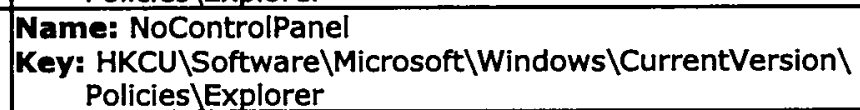 \\
\hline Disable deletion of printers & $\begin{array}{l}\text { Name: NoDeletePrinter } \\
\text { Key: HKCU\Software\Microsoft \Windows/CurrentVersion }\end{array}$ \\
\hline
\end{tabular}




\begin{tabular}{|c|c|}
\hline & Policies\Explorer \\
\hline Disable DFS tab & 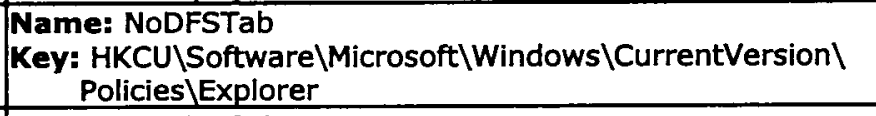 \\
\hline Disable Display in control panel & 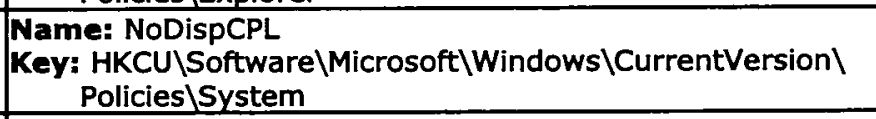 \\
\hline Disable Drag-and-Drop (Computer) & $\begin{array}{l}\text { Name: DragAndDrop } \\
\text { Key: HKLM\Software\Policies\Microsoft|Windows } \backslash \text { Task } \\
\text { Scheduler5.0 }\end{array}$ \\
\hline Disable Drag-and-Drop (User) & 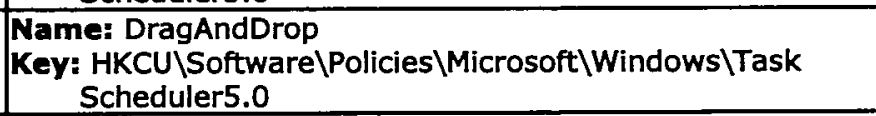 \\
\hline $\begin{array}{l}\text { Disable drag-and-drop context menus on } \\
\text { the Start Menu }\end{array}$ & 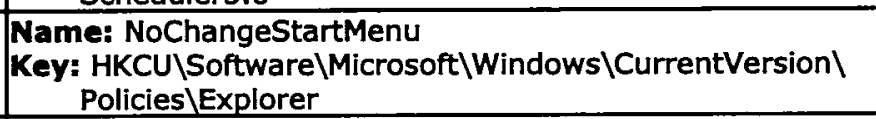 \\
\hline $\begin{array}{l}\text { Disable IE security prompt for Windows } \\
\text { Installer scripts }\end{array}$ & $\begin{array}{l}\text { Name: SafeForScripting } \\
\text { Key: HKLM\Software)Policies\Microsoft।Windows)Installer }\end{array}$ \\
\hline Disable legacy run Iist (Computer) & $\begin{array}{l}\text { Name: DisableLocalMachineRun } \\
\text { Key: HKLM\Software \Microsoft \Windows } \backslash \text { CurrentVersion } \backslash \\
\text { Policies } \backslash \text { Explorer }\end{array}$ \\
\hline Disable legacy run list (User) & $\begin{array}{l}\text { Name: DisableLocalMachineRun } \\
\text { Key: HKCU } \backslash \text { Software\Microsoft } \backslash \text { Windows } \backslash \text { CurrentVersion } \backslash \\
\text { Policies } \backslash \text { Explorer }\end{array}$ \\
\hline Disable Lock Computer & $\begin{array}{l}\text { Name: DisableLockWorkstation } \\
\text { Key: HKCU\Software\Microsoft } \backslash \text { Windows } \backslash \text { CurrentVersion } \backslash \\
\text { Policies } \backslash \text { System }\end{array}$ \\
\hline Disable Logoff & $\begin{array}{l}\begin{array}{l}\text { Name: NoLogoff } \\
\text { Key: HKCU\Software } \backslash M i c r o s o f t \backslash W i n d o w s \backslash C u r r e n t V e r s i o n \backslash \\
\text { Policies\Explorer }\end{array} \\
\end{array}$ \\
\hline Disable Logoff on the Start Menu & 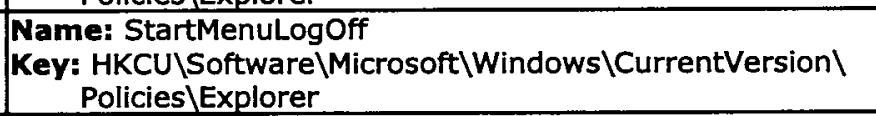 \\
\hline Disable media source for any install & $\begin{array}{l}\text { Name: DisableMedia } \\
\text { Key: HKCU\Software\Policies\Microsoft\Windows\Installer }\end{array}$ \\
\hline Disable New Task Creation (Computer) & 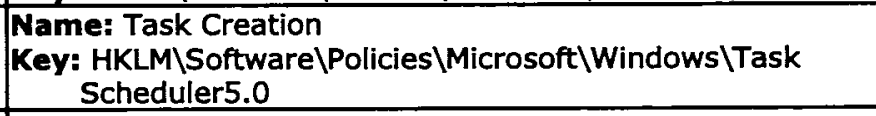 \\
\hline Disable New Task Creation (User) & $\begin{array}{l}\text { Name: Task Creation } \\
\text { Key: HKCU\Software\Policies\Microsoft } \backslash \text { Windows } \backslash \text { Task } \\
\text { Scheduler5.0 }\end{array}$ \\
\hline Disable patching & $\begin{array}{l}\text { Name: DisablePatch } \\
\text { Key: HKLM\Software\Policies\Microsoft\Windows\Installer }\end{array}$ \\
\hline Disable personalized menus & 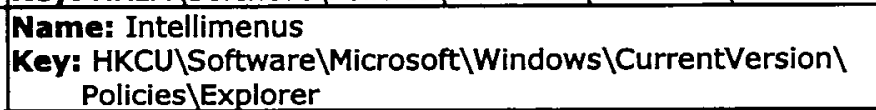 \\
\hline Disable programs on Settings menu & 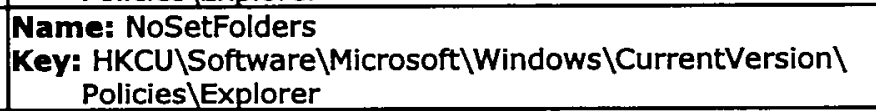 \\
\hline Disable registry editing tools & 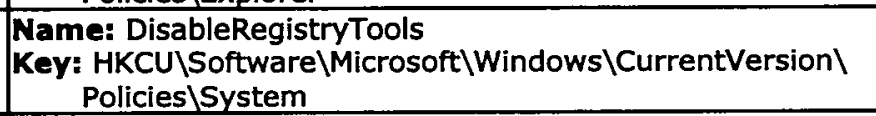 \\
\hline Disable reminder balloons (Computer) & $\begin{array}{l}\text { Name: NoReminders } \\
\text { Key: HKLM\Software\Policies\Microsoft\Windows\NetCache }\end{array}$ \\
\hline Disable reminder balloons (User) & 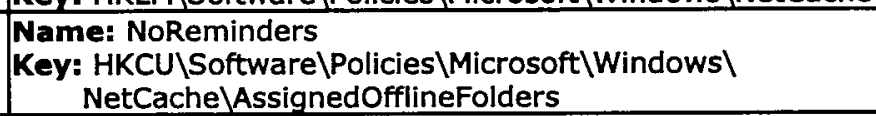 \\
\hline Disable rollback (Computer) & $\begin{array}{l}\text { Name: DisableRollback } \\
\text { Key: HKLM \Software \Policies\Microsoft\Windows \Installer }\end{array}$ \\
\hline Disable rollback (User) & $\begin{array}{l}\text { Name: DisableRollback } \\
\text { Key: HKCU\SoftwarelPolicies\Microsoft।Windows\Installer }\end{array}$ \\
\hline Disable Support Information & 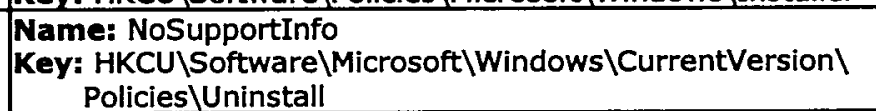 \\
\hline
\end{tabular}

CIAC-2319 


\begin{tabular}{|c|c|}
\hline Disable Task Deletion (Computer) & 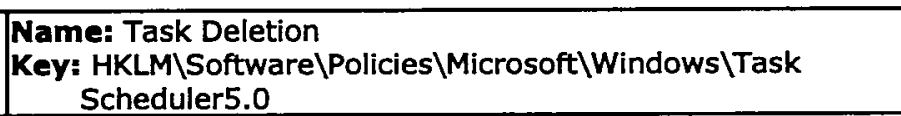 \\
\hline Disable Task Deletion (User) & 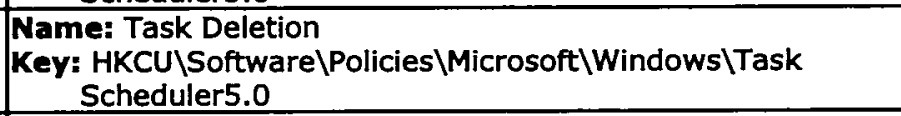 \\
\hline Disable Task Manager & 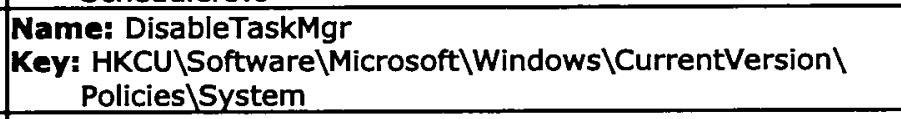 \\
\hline Disable the command prompt & 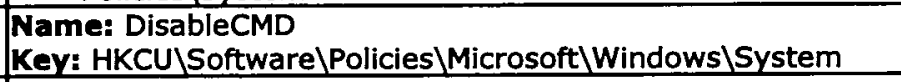 \\
\hline Disable the run once list (Computer) & $\begin{array}{l}\text { Name: DisableLocalMachineRunOnce } \\
\text { Key: HKLM\Software\Microsoft } \backslash \text { Windows } \backslash \text { CurrentVersion } \backslash \\
\text { Policies } \backslash \text { Explorer }\end{array}$ \\
\hline Disable the run once list (User) & 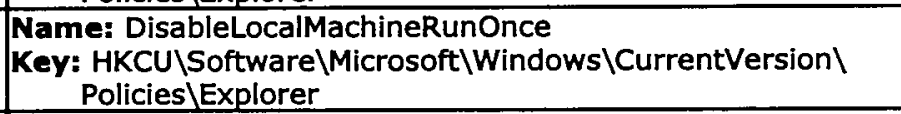 \\
\hline $\begin{array}{l}\text { Disable UI to change keyboard navigation } \\
\text { indicator setting }\end{array}$ & 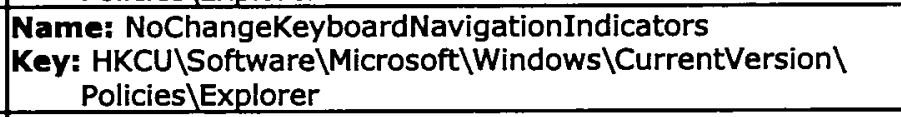 \\
\hline $\begin{array}{l}\text { Disable UI to change menu animation } \\
\text { setting }\end{array}$ & 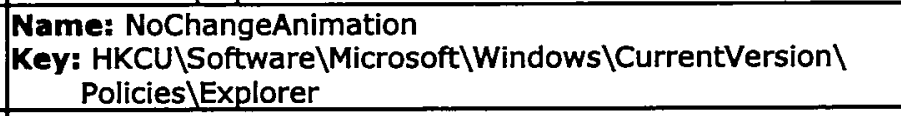 \\
\hline $\begin{array}{l}\text { Disable user configuration of Offline Files } \\
\text { (Computer) }\end{array}$ & $\begin{array}{l}\text { Name: NoConfigCache } \\
\text { Key: HKLM\Software\Policies\Microsoft)Windows\NetCache }\end{array}$ \\
\hline $\begin{array}{l}\text { Disable user configuration of Offline Files } \\
\text { (User) }\end{array}$ & $\begin{array}{l}\text { Name: NoConfigCache } \\
\text { Key: HKCU\Software\Policies\Microsoft)Windows\NetCache }\end{array}$ \\
\hline Disable user tracking & $\begin{array}{l}\text { Name: NoInstrumentation } \\
\text { Key: HKCU\Software\Microsoft } \backslash \text { Windows } \backslash \text { CurrentVersion } \backslash \\
\text { Policies } \backslash \text { Explorer }\end{array}$ \\
\hline $\begin{array}{l}\text { Disable Windows Explorer's default } \\
\text { context menu }\end{array}$ & 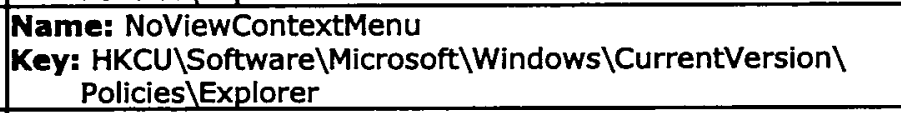 \\
\hline Disable Windows Installer & $\begin{array}{l}\text { Name: DisableMSI } \\
\text { Key: HKLM\Software\Policies\Microsoft\Windows\Installer }\end{array}$ \\
\hline Disk Quota policy processing & $\begin{array}{l}\text { Name: NoSlowLink, NoBackgroundPolicy, NoGPOListChanges } \\
\text { Key: HKLM } \backslash \text { Software } \backslash \text { Policies } \backslash \text { Microsoft } \backslash W i n d o w s \backslash G r o u p \\
\text { Policy } \backslash\{3610 \text { eda5-77ef-11d2-8dc5-00c04fa31a66\} }\end{array}$ \\
\hline $\begin{array}{l}\text { Display and enable the Network } \\
\text { Connection wizard }\end{array}$ & 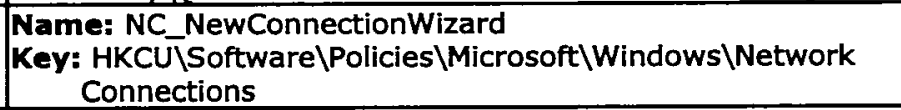 \\
\hline $\begin{array}{l}\text { Do not add shares from recently opened } \\
\text { documents to the My Network Places } \\
\text { folder }\end{array}$ & 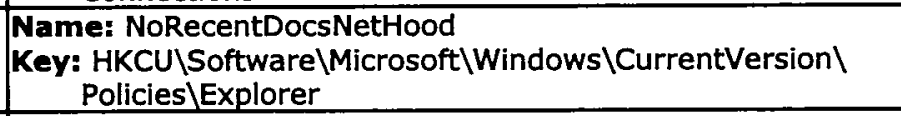 \\
\hline $\begin{array}{l}\text { Do not automatically encrypt files moved } \\
\text { to encrypted folders }\end{array}$ & $\begin{array}{l}\begin{array}{l}\text { Name: NoEncryptOnMove } \\
\text { Key: HKLM\Software } \backslash \text { Microsoft } \backslash \text { Windows } \backslash \text { CurrentVersion } \backslash \\
\text { Policies } \backslash E x p l o r e r\end{array} \\
\end{array}$ \\
\hline Do not detect slow network connections & 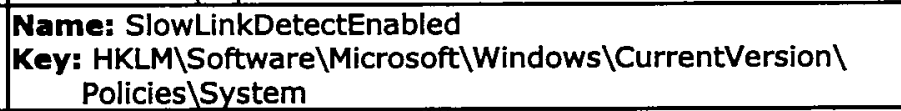 \\
\hline $\begin{array}{l}\text { Do not keep history of recently opened } \\
\text { documents }\end{array}$ & 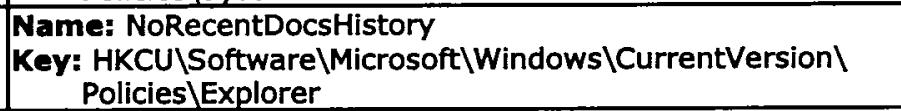 \\
\hline Do not request alternate credentials & 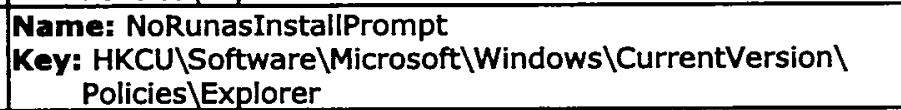 \\
\hline $\begin{array}{l}\text { Do not track Shell shortcuts during } \\
\text { roaming }\end{array}$ & 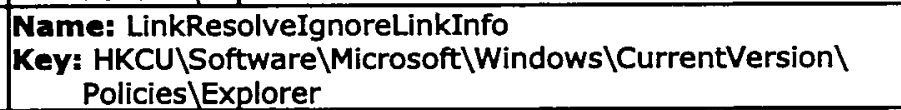 \\
\hline $\begin{array}{l}\text { Do not use the search-based method when } \\
\text { resolving shell shortcuts }\end{array}$ & 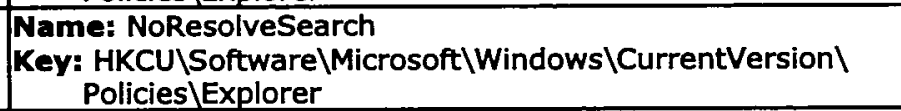 \\
\hline $\begin{array}{l}\text { Do not use the tracking-based method } \\
\text { when resolving shell shortcuts }\end{array}$ & 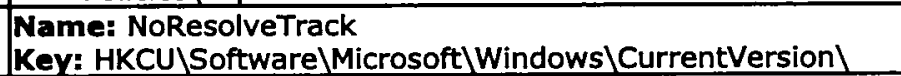 \\
\hline
\end{tabular}




\begin{tabular}{|c|c|}
\hline & Policies\Explorer \\
\hline $\begin{array}{l}\text { Don't display welcome screen at logon } \\
\text { (Computer) }\end{array}$ & 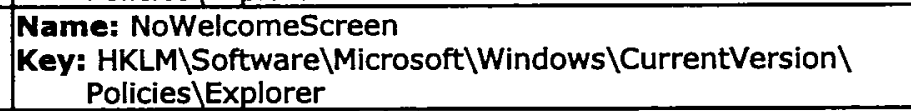 \\
\hline $\begin{array}{l}\text { Don't display welcome screen at logon } \\
\text { (User) }\end{array}$ & 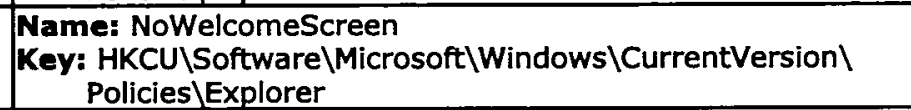 \\
\hline Don't run specified Windows applications & 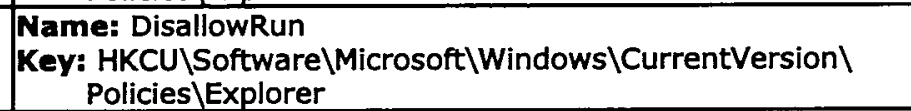 \\
\hline Don't save settings at exit & 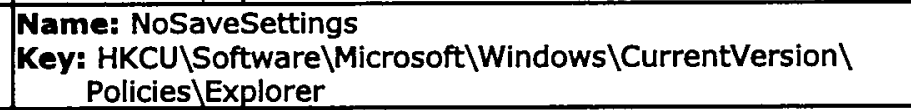 \\
\hline $\begin{array}{l}\text { Download missing COM components } \\
\text { (Computer) }\end{array}$ & 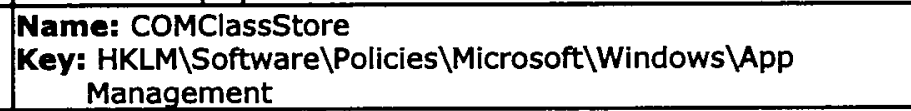 \\
\hline Download missing COM components (User) & 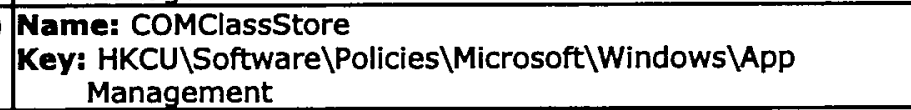 \\
\hline EFS recovery policy processing & 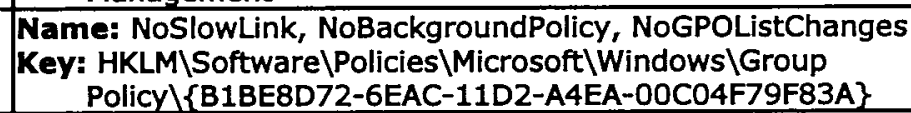 \\
\hline $\begin{array}{l}\text { Enable access to properties of a LAN } \\
\text { connection }\end{array}$ & 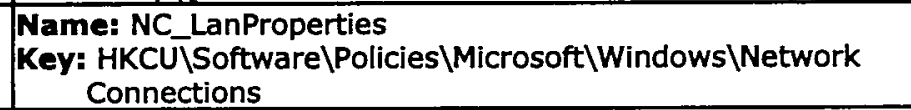 \\
\hline $\begin{array}{l}\text { Enable access to properties of components } \\
\text { of a LAN connection }\end{array}$ & $\begin{array}{l}\text { Name: NC LanChangeProperties } \\
\text { Key: HKCU\Software } \backslash \text { Policies } \backslash \text { Microsoft } \backslash \text { Windows } \backslash \text { Network } \\
\text { Connections }\end{array}$ \\
\hline $\begin{array}{l}\text { Enable access to properties of components } \\
\text { of a RAS connection }\end{array}$ & 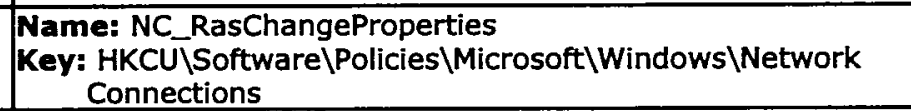 \\
\hline $\begin{array}{l}\text { Enable access to properties of RAS } \\
\text { connections available to all users }\end{array}$ & 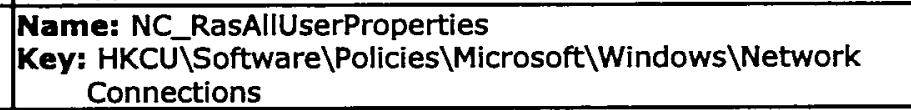 \\
\hline Enable Active Desktop & 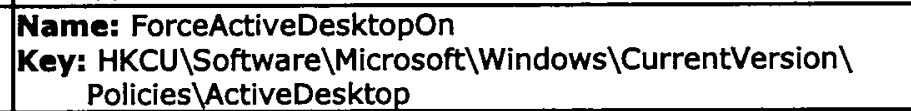 \\
\hline $\begin{array}{l}\text { Enable adding or removing components of } \\
\text { a RAS or LAN connection }\end{array}$ & 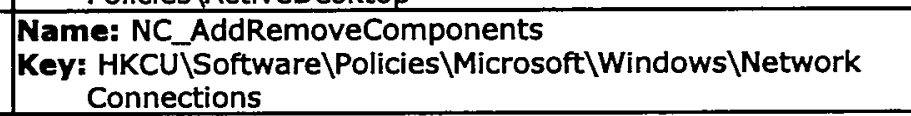 \\
\hline Enable Classic Shell & $\begin{array}{l}\begin{array}{l}\text { Name: ClassicShell } \\
\text { Key: HKCU\Software\Microsoft } \backslash \text { Windows } \backslash \text { CurrentVersion } \backslash \\
\text { Policies } \backslash \text { Explorer }\end{array} \\
\end{array}$ \\
\hline $\begin{array}{l}\text { Enable connecting and disconnecting a } \\
\text { LAN connection }\end{array}$ & 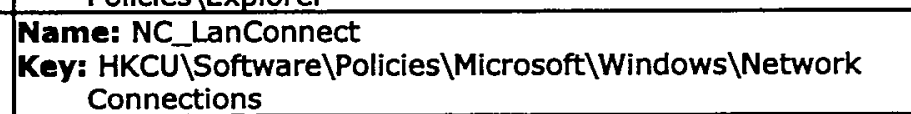 \\
\hline $\begin{array}{l}\text { Enable connecting and disconnecting a } \\
\text { RAS connection }\end{array}$ & 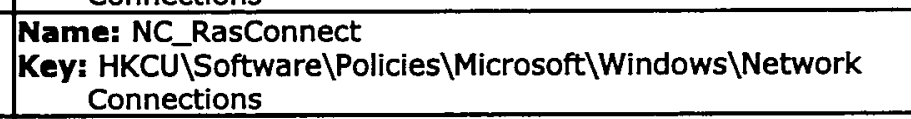 \\
\hline Enable deletion of RAS connections & 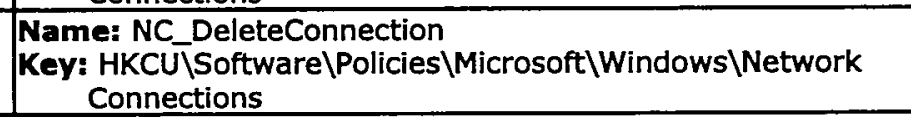 \\
\hline $\begin{array}{l}\text { Enable deletion of RAS connections } \\
\text { available to all users }\end{array}$ & 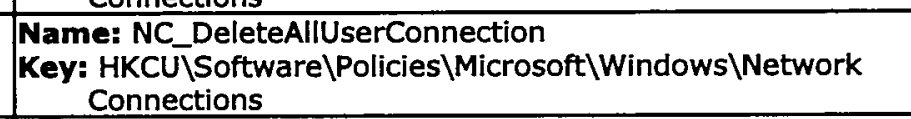 \\
\hline Enable disk quotas & 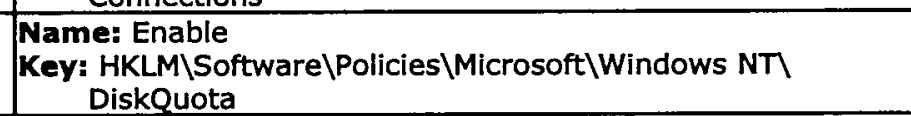 \\
\hline Enable filter in Find dialog box & 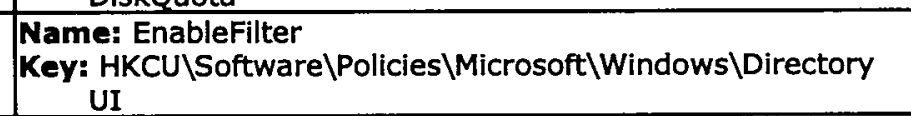 \\
\hline $\begin{array}{l}\text { Enable renaming of connections, if } \\
\text { supported }\end{array}$ & 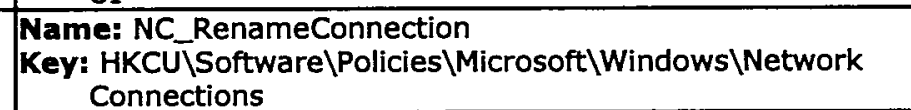 \\
\hline
\end{tabular}

CIAC-2319 


\begin{tabular}{|c|c|}
\hline $\begin{array}{l}\text { Enable renaming of RAS connections } \\
\text { belonging to the current user }\end{array}$ & 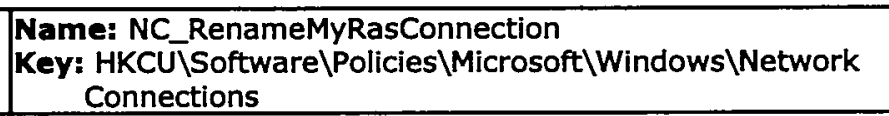 \\
\hline $\begin{array}{l}\text { Enable status statistics for an active } \\
\text { connection }\end{array}$ & 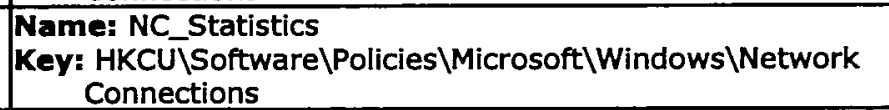 \\
\hline $\begin{array}{l}\text { Enable the Advanced Settings item on the } \\
\text { Advanced menu }\end{array}$ & 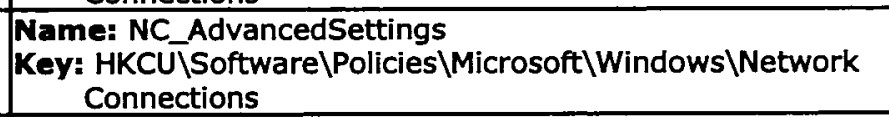 \\
\hline $\begin{array}{l}\text { Enable the Dial-up Preferences item on the } \\
\text { Advanced menu }\end{array}$ & 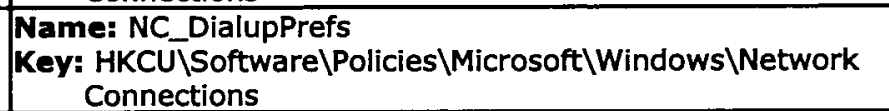 \\
\hline Enable user control over installs & $\begin{array}{l}\text { Name: EnableUserControl } \\
\text { Key: HKLMISoftware Policies\Microsoft।Windows\Installer }\end{array}$ \\
\hline $\begin{array}{l}\text { Enable user to browse for source while } \\
\text { elevated }\end{array}$ & $\begin{array}{l}\text { Name: AllowLockdownBrowse } \\
\text { Key: HKLM\Software Policies\Microsoft।Windows Installer }\end{array}$ \\
\hline Enable user to patch elevated products & $\begin{array}{l}\text { Name: AllowLockdownPatch } \\
\text { Key: HKLM\Software\Policies\Microsoft|Windows\Installer }\end{array}$ \\
\hline $\begin{array}{l}\text { Enable user to use media source while } \\
\text { elevated }\end{array}$ & $\begin{array}{l}\text { Name: AllowLockdownMedia } \\
\text { Key: HKLMISoftware\Policies\Microsoft\Windows Installer }\end{array}$ \\
\hline Enabled & $\begin{array}{l}\text { Name: Enabled } \\
\text { Key: HKLMISoftware\Policies\Microsoft\Windows\WetCache }\end{array}$ \\
\hline Enforce disk quota limit & 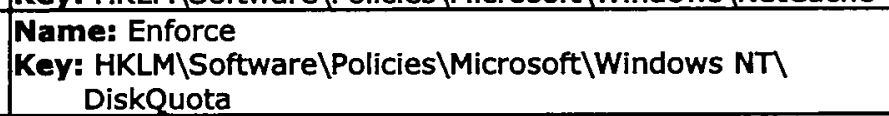 \\
\hline Enforce Show Policies Only & 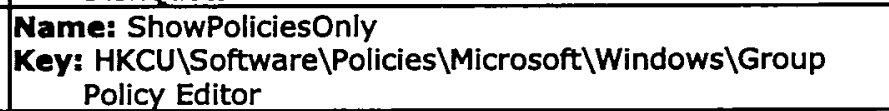 \\
\hline Event logging level (Computer) & 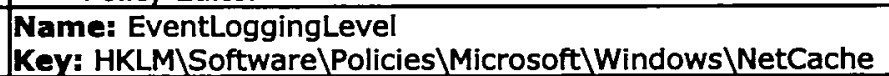 \\
\hline Event logging level (User) & 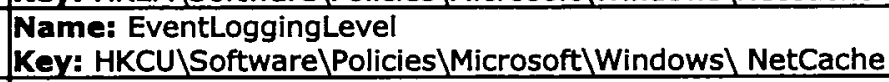 \\
\hline Exclude directories in roaming profile & $\begin{array}{l}\text { Name: ExcludeProfileDirs } \\
\text { Key: HKCU\Software\Policies\Microsoft|Windows\System }\end{array}$ \\
\hline FAX Service & 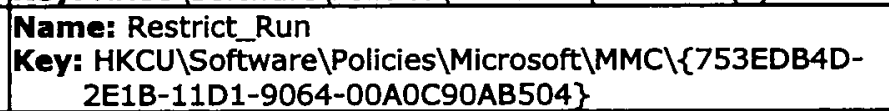 \\
\hline Files not cached & $\begin{array}{l}\text { Name: ExcludeExtensions } \\
\text { Key: HKLMISoftware } \\
\end{array}$ \\
\hline Folder Redirection policy processing & $\begin{array}{l}\text { Name: NoSlowLink, NoGPOListChanges } \\
\text { Key: HKLM } \backslash \text { Software } \backslash \text { Policies } \backslash M i c r o s o f t \backslash W i n d o w s \backslash G r o u p \\
\text { Policy } \backslash\{25537 B A 6-77 A 8-11 D 2-9 B 6 C-0000 F 8080861\}\end{array}$ \\
\hline Go directly to Components wizard & 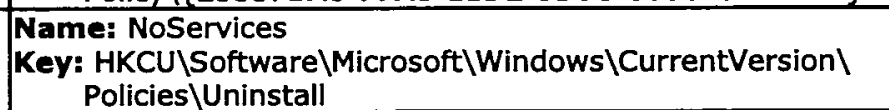 \\
\hline $\begin{array}{l}\text { Gray unavailable Windows Installer } \\
\text { programs Start Menu shortcuts }\end{array}$ & 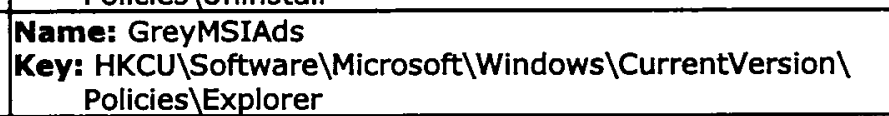 \\
\hline Group Policy domain controller selection & $\begin{array}{l}\text { Name: DCOption } \\
\text { Key: HKCU\Software\Policies\Microsoft } \backslash \text { Windows } \backslash \text { Group } \\
\text { Policy Editor }\end{array}$ \\
\hline $\begin{array}{l}\text { Group Policy refresh interval for } \\
\text { computers }\end{array}$ & 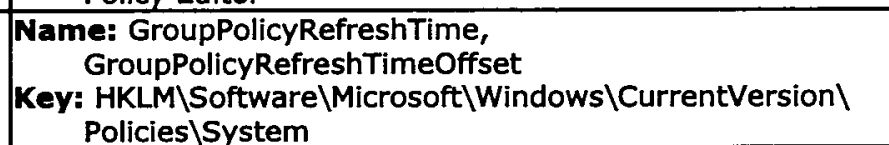 \\
\hline $\begin{array}{l}\text { Group Policy refresh interval for domain } \\
\text { controllers }\end{array}$ & $\begin{array}{l}\text { Name: GroupPolicyRefreshTimeDC, } \\
\text { GroupPolicyRefreshTimeOffsetDC } \\
\text { Key: HKLMISoftware)Policies\Microsoft|Windows \System }\end{array}$ \\
\hline Group Policy refresh interval for users & 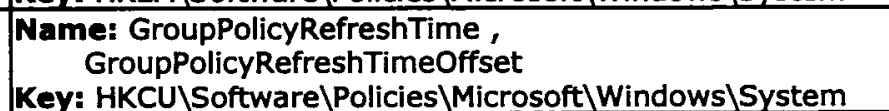 \\
\hline $\begin{array}{l}\text { Group Policy slow link detection } \\
\text { (Computer) }\end{array}$ & 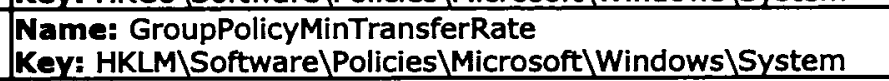 \\
\hline Group Policy slow link detection (User) & Name: GroupPolicyMinTransferRate \\
\hline
\end{tabular}

CIAC-2319 


\begin{tabular}{|c|c|}
\hline & Key: HKCU\Software\Policies\Microsoft|Windows\System \\
\hline Group Policy snap-in & 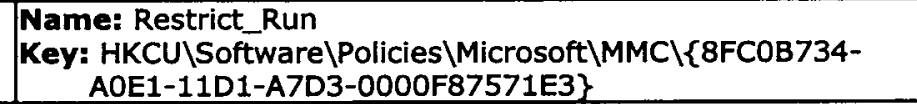 \\
\hline Hide Active Directory folder & $\begin{array}{l}\begin{array}{l}\text { Name: HideDirectoryFolder } \\
\text { Key: HKCU \Software } \backslash \text { Policies } \backslash \text { Microsoft } \backslash \text { Windows } \backslash \text { Directory } \\
\text { UI }\end{array} \\
\end{array}$ \\
\hline Hide Add New Programs page & 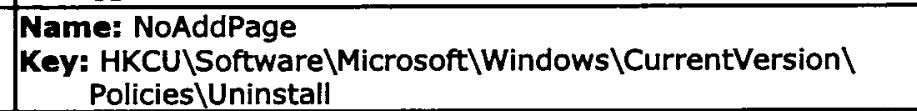 \\
\hline $\begin{array}{l}\text { Hide Add/Remove Windows Components } \\
\text { page }\end{array}$ & 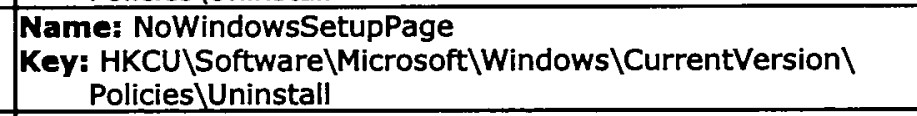 \\
\hline Hide all icons on Desktop & 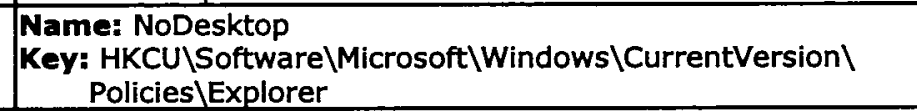 \\
\hline Hide Appearance tab & $\begin{array}{l}\begin{array}{l}\text { Name: NoDispAppearancePage } \\
\text { Key: HKCU\Software\Microsoft } \backslash \text { Windows } \backslash \text { CurrentVersion } \backslash \\
\text { Policies } \backslash S y s t e m\end{array} \\
\end{array}$ \\
\hline Hide Background tab & 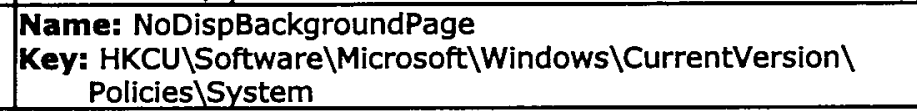 \\
\hline Hide Change or Remove Programs page & 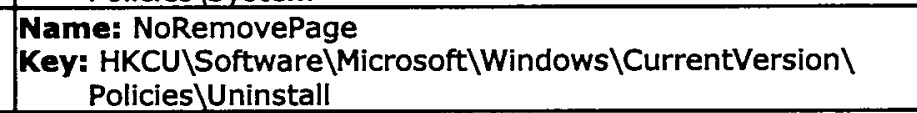 \\
\hline Hide Hardware tab & 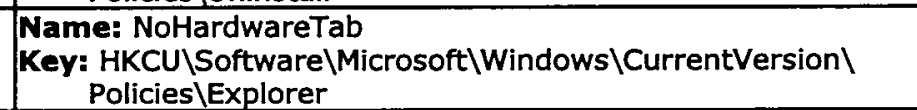 \\
\hline Hide Internet Explorer icon on desktop & 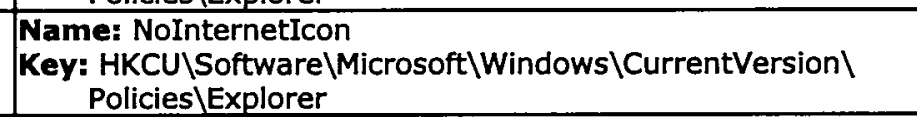 \\
\hline Hide My Network Places icon on desktop & $\begin{array}{l}\text { Name: NoNetHood } \\
\text { Key: HKCU\Software\Microsoft } \backslash W i n d o w s \backslash C u r r e n t V e r s i o n \backslash \\
\text { Policies\Explorer }\end{array}$ \\
\hline Hide Property Pages (Computer) & \begin{tabular}{|l|} 
Name: Property Pages \\
Key: HKLM\Software\Policies $\backslash$ Microsoft $\backslash$ Windows $\backslash$ Task \\
Scheduler5.0
\end{tabular} \\
\hline Hide Property Pages (User) & \begin{tabular}{|l}
$\begin{array}{l}\text { Name: Property Pages } \\
\text { Key: HKCU\Software\Policies } \backslash \text { Microsoft } \backslash \text { Windows } \backslash \text { Task } \\
\text { Scheduler5.0 }\end{array}$ \\
\end{tabular} \\
\hline Hide Screen Saver tab & 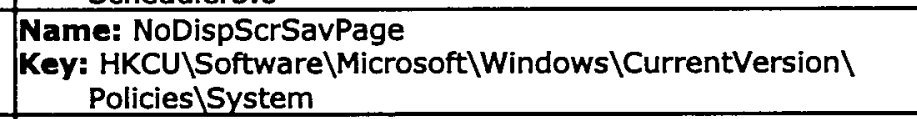 \\
\hline Hide Settings tab & 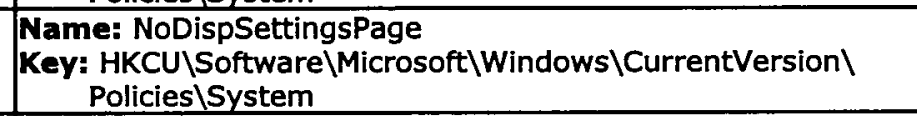 \\
\hline Hide specified control panel applets & 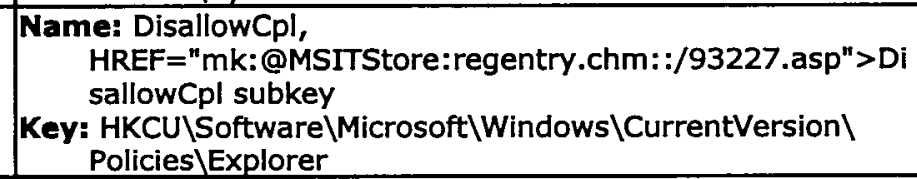 \\
\hline $\begin{array}{l}\text { Hide the "Add a program from CD-ROM or } \\
\text { floppy disk" option }\end{array}$ & 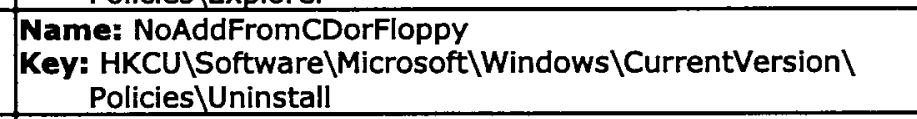 \\
\hline $\begin{array}{l}\text { Hide the "Add programs from Microsoft" } \\
\text { option }\end{array}$ & 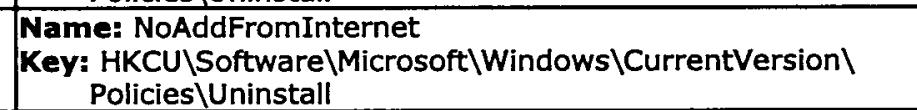 \\
\hline $\begin{array}{l}\text { Hide the "Add programs from your } \\
\text { network" option }\end{array}$ & 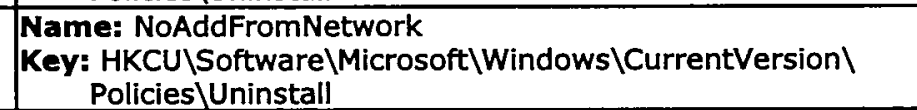 \\
\hline Hide the common dialog back button & 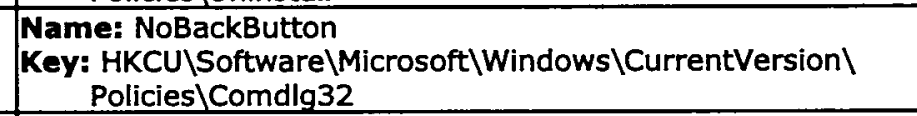 \\
\hline Hide the common dialog places bar & Name: NoPlacesBar \\
\hline
\end{tabular}

CIAC-2319 


\begin{tabular}{|c|c|}
\hline & 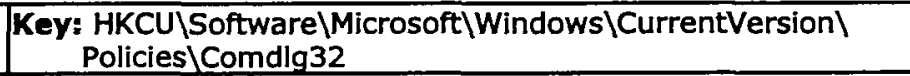 \\
\hline Hide the dropdown list of recent files & 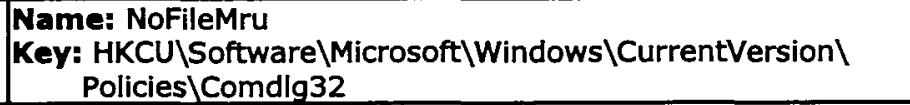 \\
\hline Hide the file scan progress window & 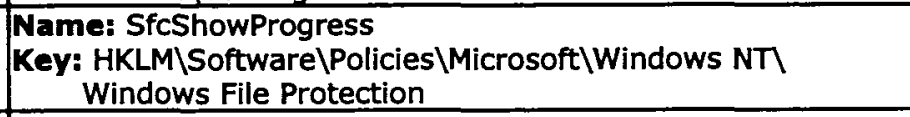 \\
\hline Hide these specified drives in My Computer & 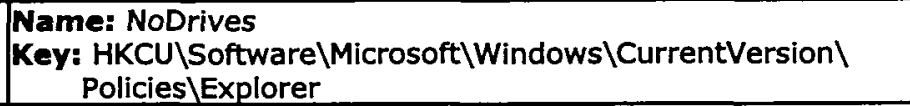 \\
\hline $\begin{array}{l}\text { Hides the Manage item on the Windows } \\
\text { Explorer context menu }\end{array}$ & 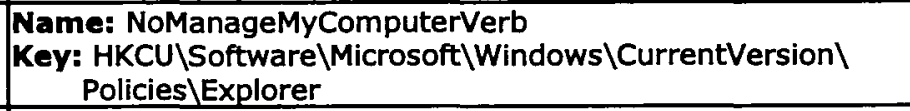 \\
\hline $\begin{array}{l}\text { Initial reminder balloon lifetime } \\
\text { (Computer) }\end{array}$ & $\begin{array}{l}\text { Name: InitialBalloonTimeoutSeconds } \\
\text { Key: HKLMJSoftware/Policies\Microsoft/Windows\WetCache }\end{array}$ \\
\hline Initial reminder balloon lifetime (User) & 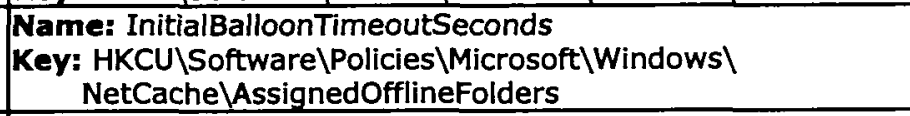 \\
\hline $\begin{array}{l}\text { Internet Explorer Maintenance policy } \\
\text { processing }\end{array}$ & 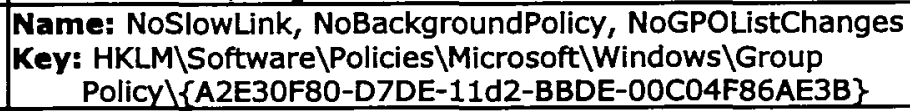 \\
\hline IP Security policy processing & 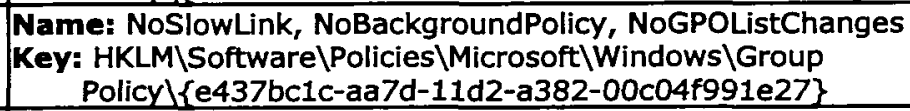 \\
\hline Limit profile size & 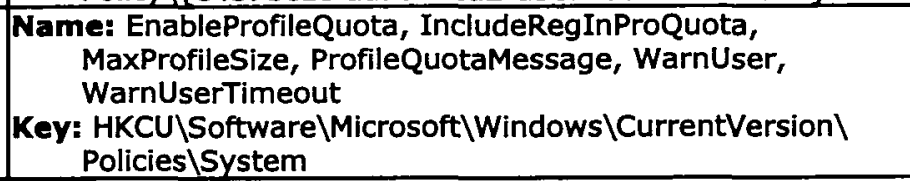 \\
\hline Limit Windows File Protection cache size & \begin{tabular}{|l|}
$\begin{array}{l}\text { Name: SfcQuota } \\
\text { Key: HKLM\Software\Policies } \backslash \text { Microsoft } \backslash \text { Windows NT } \\
\text { Windows File Protection }\end{array}$ \\
\end{tabular} \\
\hline Log event when quota limit exceeded & $\begin{array}{l}\begin{array}{l}\text { Name: LogEventOverLimit } \\
\text { Key: HKLM\Software\Policies\Microsoft } \backslash \text { Windows NT } \\
\text { DiskQuota }\end{array} \\
\end{array}$ \\
\hline $\begin{array}{l}\text { Log event when quota warning level } \\
\text { exceeded }\end{array}$ & $\begin{array}{l}\text { Name: LogEventOverThreshold } \\
\text { Key: HKLM\Software\Policies\Microsoft|Windows NT } \\
\text { DiskQuota }\end{array}$ \\
\hline Log users off when roaming profile fails & $\begin{array}{l}\text { Name: ProfileErrorAction } \\
\text { Key: HKLM\Software\Policies\Microsoft|Windows\System }\end{array}$ \\
\hline Logging & $\begin{array}{l}\text { Name: Logging } \\
\text { Key: HKLM\Software \Policies\Microsoft\Windows\Installer }\end{array}$ \\
\hline Maximum number of Recent documents & 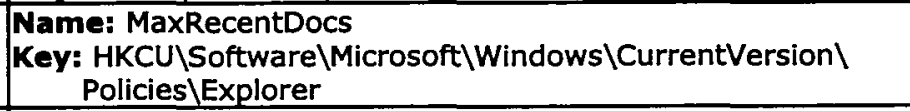 \\
\hline $\begin{array}{l}\text { Maximum retries to unload and update } \\
\text { user profile }\end{array}$ & $\begin{array}{l}\text { Name: ProfileUnloadTimeout } \\
\text { Key: HKLM\SOFTWARE\Policies\Microsoft\Windows \System }\end{array}$ \\
\hline Maximum size of Active Directory searches & 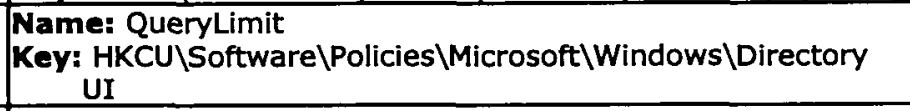 \\
\hline $\begin{array}{l}\text { Maximum wait time for Group Policy } \\
\text { scripts }\end{array}$ & 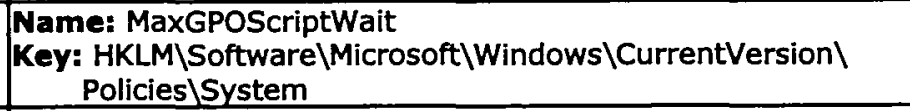 \\
\hline $\begin{array}{l}\text { No "Computers Near Me" in My Network } \\
\text { Places }\end{array}$ & 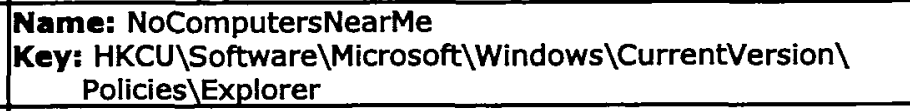 \\
\hline No "Entire Network" in My Network Places & 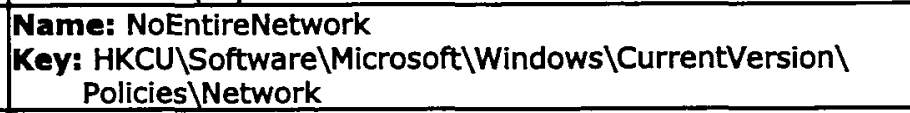 \\
\hline No screen saver & 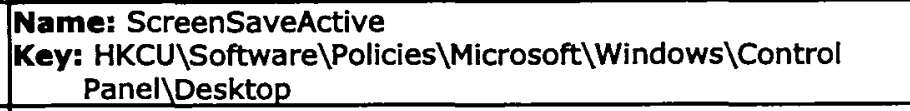 \\
\hline Non-default server disconnect actions & Name: CustomGoOfflineActions subkey \\
\hline
\end{tabular}




\begin{tabular}{|c|c|}
\hline (Computer & 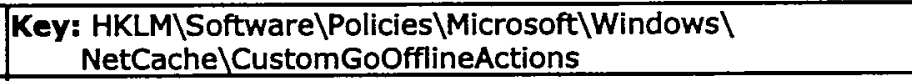 \\
\hline $\begin{array}{l}\text { Non-default server disconnect actions } \\
\text { (User }\end{array}$ & $\begin{array}{l}\text { Name: CustomGoOfflineActions subkey } \\
\text { Key: HKCU\Software\Policies\Microsoft } \backslash \text { Windows } \backslash \\
\text { NetCachelCustomGoOfflineActions }\end{array}$ \\
\hline Only allow approved Shell extensions & 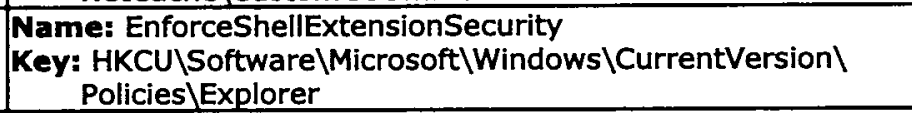 \\
\hline Password protect the screen saver & 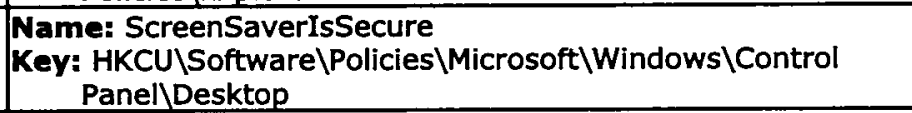 \\
\hline Pre-populate printer search location text & $\begin{array}{l}\text { Name: PhysicalLocationSupport } \\
\text { Key: HKLM\Software\Policies\Microsoft|Windows NT } \text { Printers }\end{array}$ \\
\hline $\begin{array}{l}\text { Prevent access to drives from My } \\
\text { Computer }\end{array}$ & 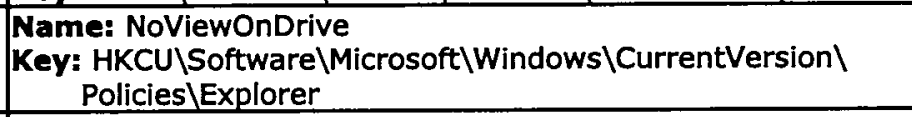 \\
\hline Prevent Task Run or End (Computer & $\begin{array}{l}\text { Name: Execution } \\
\text { Key: HKLM } \backslash \text { Software } \backslash \text { Policies } \backslash \text { Microsoft } \backslash \text { Windows } \backslash \text { Task } \\
\text { Scheduler5.0 }\end{array}$ \\
\hline Prevent Task Run or End (User & $\begin{array}{l}\text { Name: Execution } \\
\text { Key: HKCU\Software\Policies } \backslash \text { Microsoft } \backslash \text { Windows } \backslash \text { Task } \\
\text { Scheduler5.0 }\end{array}$ \\
\hline $\begin{array}{l}\text { Prevent use of Offiline Files folder } \\
\text { (Computer) }\end{array}$ & $\begin{array}{l}\text { Name: NoCacheViewer } \\
\text { Key: HKLM\Software\Policies\Microsoft\Windows\NetCache }\end{array}$ \\
\hline Prevent use of Offline Files Folder (User) & 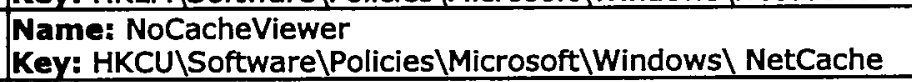 \\
\hline Primary DNS Suffix & 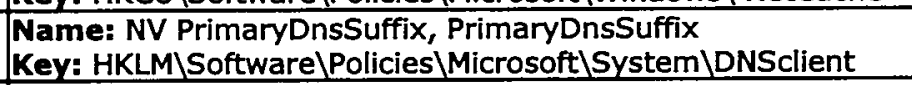 \\
\hline Printer browsing & $\begin{array}{l}\text { Name: ServerThread } \\
\text { Key: HKLMISoftware\Policies\Microsoft|Windows NT\ Printers }\end{array}$ \\
\hline Prohibit adding items & \begin{tabular}{l}
$\begin{array}{l}\text { Name: NoAddingComponents } \\
\text { Key: HKCU\Software } \backslash \text { Microsoft } \backslash \text { Windows } \backslash \text { CurrentVersion\} } \\
{\text { Policies \ActiveDesktop }} \\
\end{array}$ \\
\hline Prohibit Browse (Computer) & $\begin{array}{l}\text { Name: Allow Browse } \\
\text { Key: HKLM\Software\Policies\Microsoft } \backslash \text { Windows } \backslash \text { Task } \\
\text { Scheduler5.0 }\end{array}$ \\
\hline Prohibit Browse (User) & 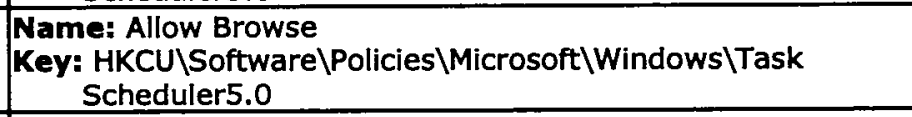 \\
\hline Prohibit changes & 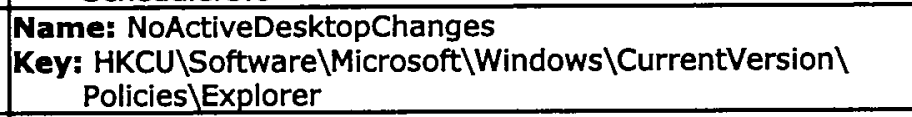 \\
\hline Prohibit closing items & 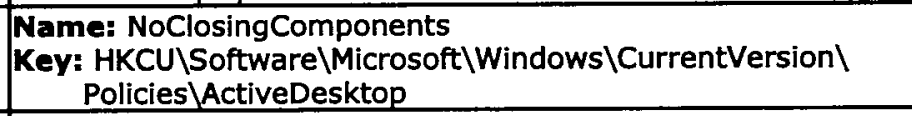 \\
\hline Prohibit deleting items & 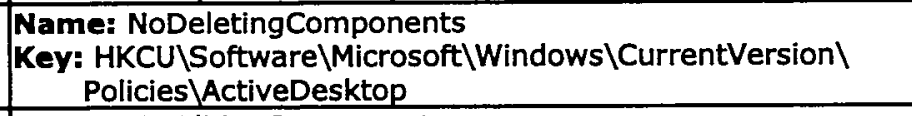 \\
\hline Prohibit editing items & 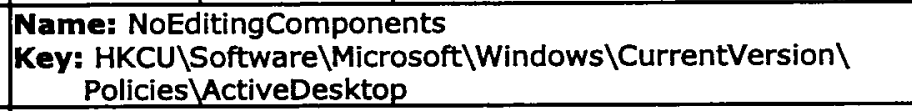 \\
\hline $\begin{array}{l}\text { Prohibit user from changing My Documents } \\
\text { path }\end{array}$ & 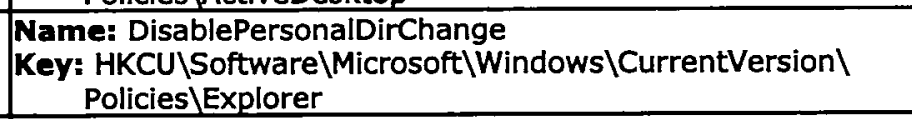 \\
\hline Prompt user when slow link is detected & $\begin{array}{l}\begin{array}{l}\text { Name: SlowLinkUIEnabled } \\
\text { Key: HKLM } \backslash \text { Software } \backslash \text { Microsoft } \backslash \text { Windows } \backslash \text { CurrentVersion } \backslash \\
\text { Policies } \backslash \text { System }\end{array} \\
\end{array}$ \\
\hline $\begin{array}{l}\text { Prune printers that are not automatically } \\
\text { republished }\end{array}$ & $\begin{array}{l}\text { Name: PruneDownlevel } \\
\text { Key: HKLM\SoftwarelPolicies\Microsoft/Windows NT \ Printers }\end{array}$ \\
\hline Registry policy processing & 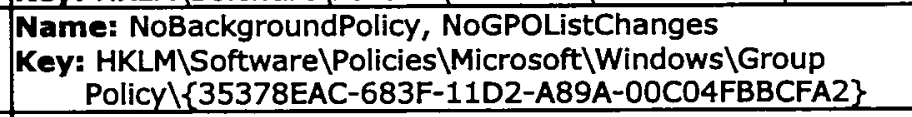 \\
\hline Reminder balloon frequency (Computer) & 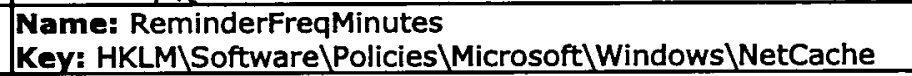 \\
\hline
\end{tabular}
\end{tabular}




\begin{tabular}{|c|c|}
\hline Reminder balloon frequency (User) & 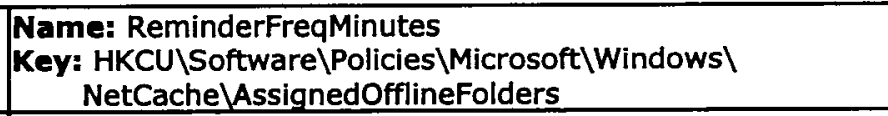 \\
\hline Reminder balloon lifetime (Computer) & $\begin{array}{l}\text { Name: ReminderBalloonTimeoutSeconds } \\
\text { Key: HKLM\Software } \backslash \text { Policies\Microsoft|Windows\NetCache }\end{array}$ \\
\hline Reminder balloon lifetime (User) & 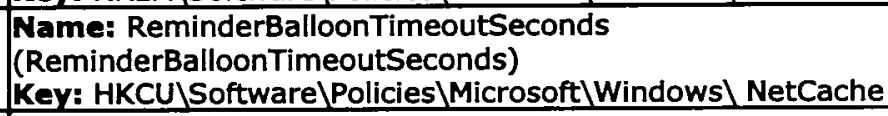 \\
\hline $\begin{array}{l}\text { Remove "Map Network Drive" and } \\
\text { "Disconnect Network Drive" }\end{array}$ & 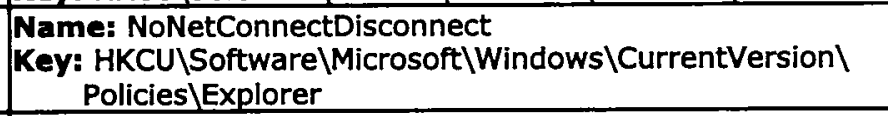 \\
\hline $\begin{array}{l}\text { Remove common program groups from } \\
\text { Start Menu }\end{array}$ & 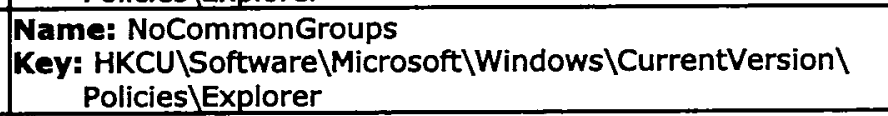 \\
\hline $\begin{array}{l}\text { Remove Disconnect item from Start menu } \\
\text { (Terminal Services only) }\end{array}$ & 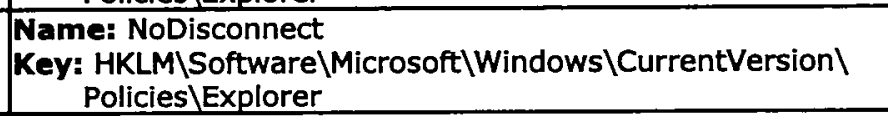 \\
\hline Remove Documents menu from Start Menu & 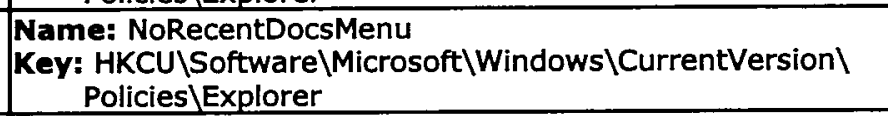 \\
\hline Remove Favorites menu from Start Menu & 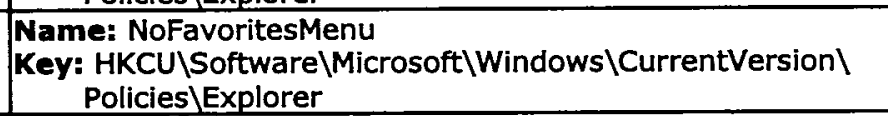 \\
\hline Remove File menu from Windows Explorer & 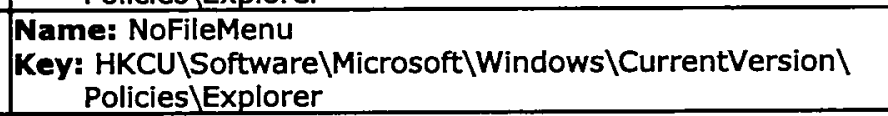 \\
\hline Remove Help menu from Start Menu & $\begin{array}{l}\text { Name: NoSMHelp } \\
\text { Key: HKCU\Software\Microsoft } \backslash \text { Windows } \backslash \text { CurrentVersion } \backslash \\
\text { Policies } \backslash \text { Explorer }\end{array}$ \\
\hline Remove My Documents icon from desktop & $\begin{array}{l}\text { Name: }\{450 D 8 F B A-A D 25-11 D 0-98 A 8-0800361 B 1103\} \\
\text { Key: HKCU\Software } \backslash \text { Microsoft } \backslash \text { Windows } \backslash \text { CurrentVersion } \backslash \\
\text { Policies } \backslash \text { NonEnum }\end{array}$ \\
\hline $\begin{array}{l}\text { Remove My Documents icon from Start } \\
\text { Menu }\end{array}$ & 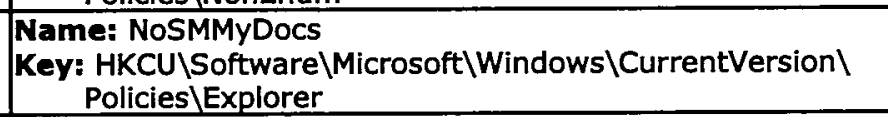 \\
\hline $\begin{array}{l}\text { Remove Network \& Dial-up Connections } \\
\text { from Start Menu }\end{array}$ & 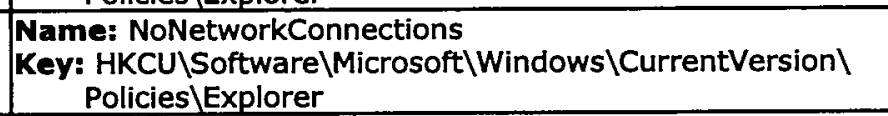 \\
\hline Remove Run menu from Start Menu & 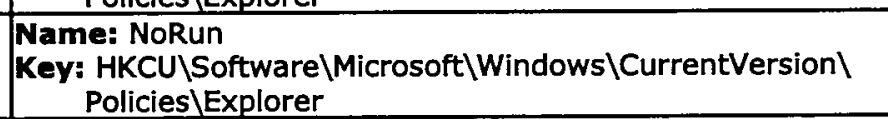 \\
\hline $\begin{array}{l}\text { Remove Search button from Windows } \\
\text { Explorer }\end{array}$ & 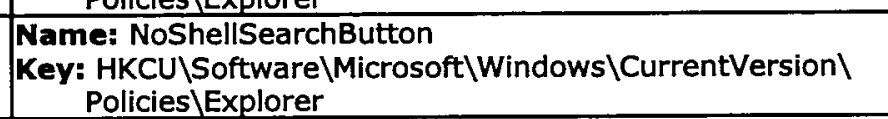 \\
\hline Remove Search menu from Start Menu & $\begin{array}{l}\begin{array}{l}\text { Name: NoFind } \\
\text { Key: HKCU\Software } \backslash \text { Microsoft } \backslash W i n d o w s \backslash C u r r e n t V e r s i o n \backslash \\
\text { Policies } \backslash \text { Explorer }\end{array} \\
\end{array}$ \\
\hline $\begin{array}{l}\text { Remove security option from Start menu } \\
\text { (Terminal Services only }\end{array}$ & 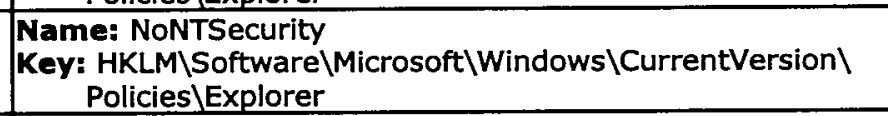 \\
\hline $\begin{array}{l}\text { Remove the Folder Options menu item } \\
\text { from the Tools menu }\end{array}$ & 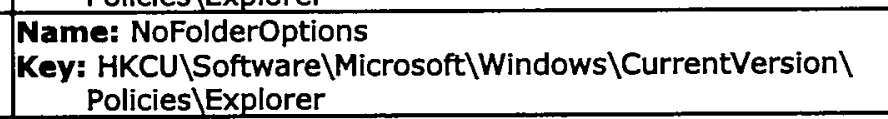 \\
\hline Remove user's folders from the Start Menu & 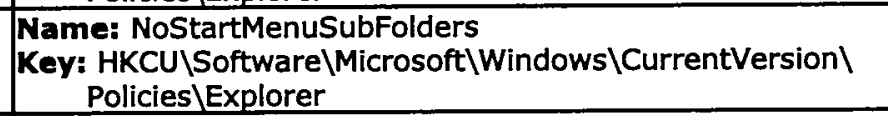 \\
\hline $\begin{array}{l}\text { Request credentials for network } \\
\text { installations }\end{array}$ & 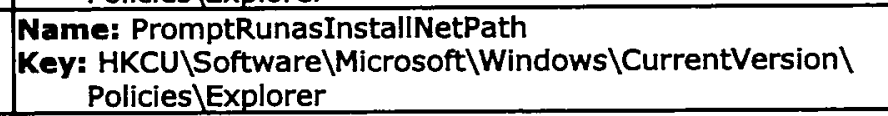 \\
\hline $\begin{array}{l}\text { Restrict selection of Windows } 2000 \text { menus } \\
\text { and dialogs language }\end{array}$ & 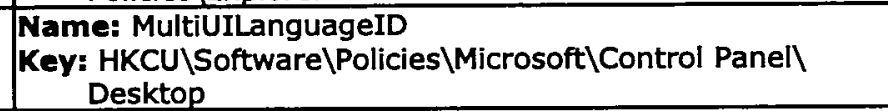 \\
\hline $\begin{array}{l}\text { Restrict the user from entering author } \\
\text { mode }\end{array}$ & $\begin{array}{l}\text { Name: RestrictAuthorMode } \\
\text { Key: HKCU\Software\Policies\Microsoft\MMC }\end{array}$ \\
\hline
\end{tabular}




\begin{tabular}{|c|c|}
\hline $\begin{array}{l}\text { Restrict users to the explicitly permitted } \\
\text { list of snap-ins }\end{array}$ & $\begin{array}{l}\text { Name: RestrictToPermittedSnapins } \\
\text { Key: HKCU\Software\Policies\Microsoft\MMC }\end{array}$ \\
\hline Run legacy logon scripts hidden & 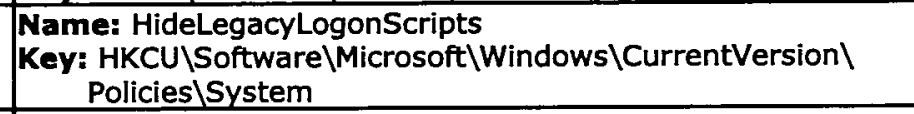 \\
\hline Run logoff scripts visible & 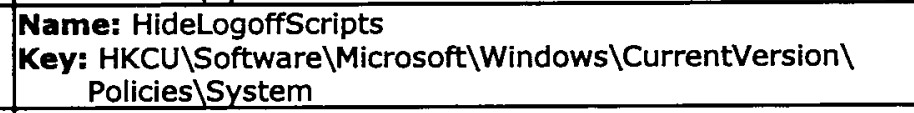 \\
\hline $\begin{array}{l}\text { Run logon scripts synchronously } \\
\text { (Computer) }\end{array}$ & $\begin{array}{l}\text { Name: RunLogonScriptSync } \\
\text { Key: HKLM\Software\Microsoft } \backslash \text { Windows } \backslash \text { CurrentVersion } \backslash \\
\text { Policies } \backslash S y s t e m\end{array}$ \\
\hline Run logon scripts synchronously (User) & 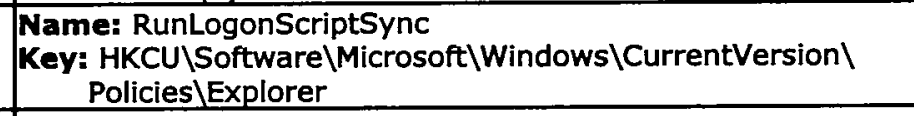 \\
\hline Run logon scripts visible & 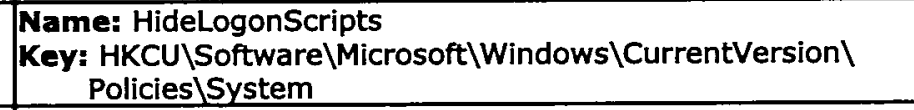 \\
\hline Run only allowed Windows applications & 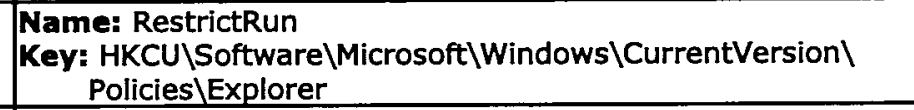 \\
\hline Run shutdown scripts visible & 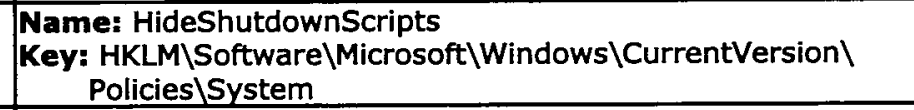 \\
\hline Run startup scripts asynchronously & 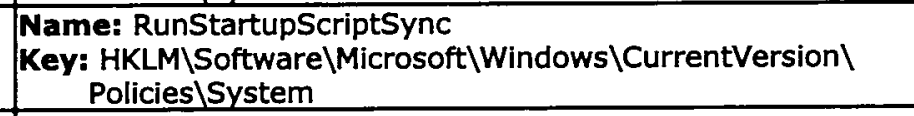 \\
\hline Run startup scripts visible & $\begin{array}{l}\begin{array}{l}\text { Name: HideStartupScripts } \\
\text { Key: HKLM\Software\Microsoft } \backslash \text { Windows } \backslash \text { CurrentVersion } \backslash \\
\text { Policies\System }\end{array} \\
\end{array}$ \\
\hline $\begin{array}{l}\text { Run these programs at user logon } \\
\text { (Computer) }\end{array}$ & 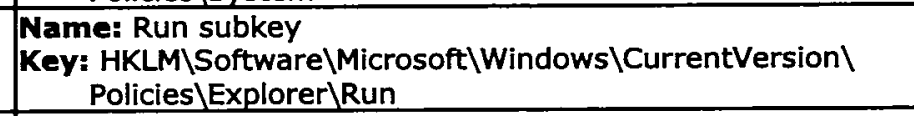 \\
\hline Run these programs at user logon (Use)r & 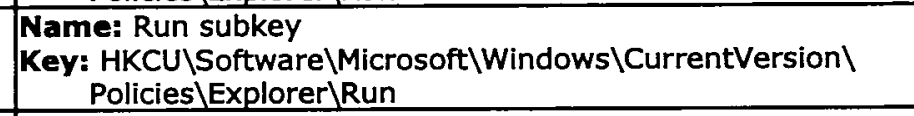 \\
\hline Screen saver executable name & $\begin{array}{l}\begin{array}{l}\text { Name: SCRNSAVE.EXE } \\
\text { Key: HKCU\Software\Policies } \backslash \text { Microsoft } \backslash \text { Windows } \backslash \text { Control } \\
\text { Panel\Desktop }\end{array} \\
\end{array}$ \\
\hline Scripts policy processing & 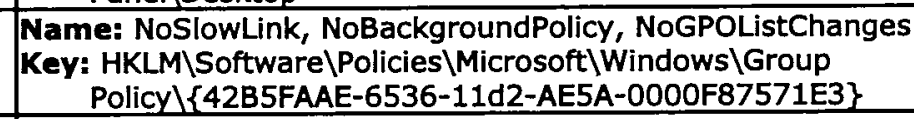 \\
\hline Search order & $\begin{array}{l}\text { Name: SearchOrder } \\
\text { Key: HKCU\Software\Policies\Microsoft|Windows\Installer }\end{array}$ \\
\hline Security policy processing & 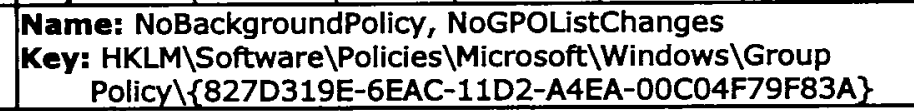 \\
\hline Set Windows File Protection scanning & $\begin{array}{l}\begin{array}{l}\text { Name: SfCScan } \\
\text { Key: HKLM\Software\Policies\Microsoft|Windows NT } \\
\text { Windows File Protection }\end{array} \\
\end{array}$ \\
\hline Show only specified control panel applets & 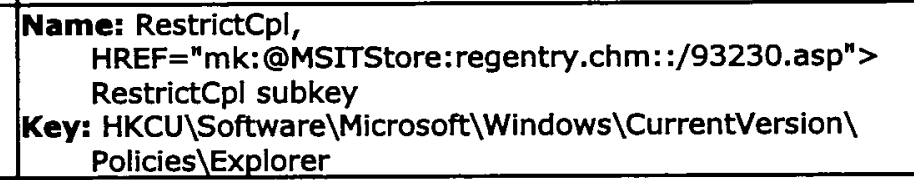 \\
\hline $\begin{array}{l}\text { Slow network connection timeout for user } \\
\text { profiles }\end{array}$ & 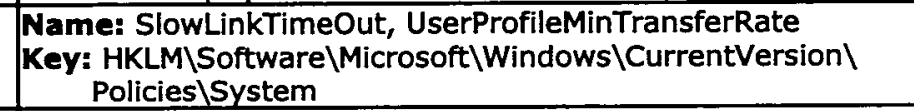 \\
\hline Software Installation policy processing & 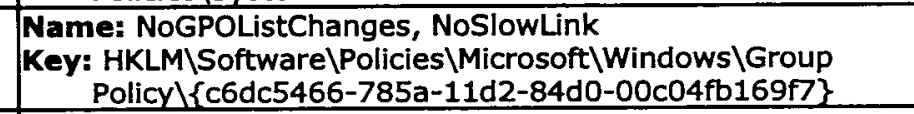 \\
\hline $\begin{array}{l}\text { Specify default category for Add New } \\
\text { Programs }\end{array}$ & 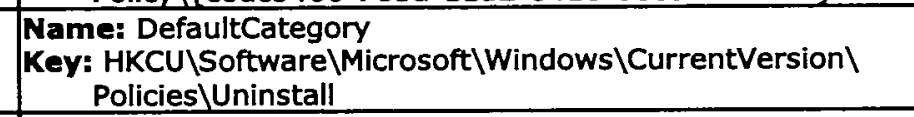 \\
\hline Specify Windows File Protection cache & Name: SFCDIICacheDir \\
\hline
\end{tabular}

CIAC-2319 


\begin{tabular}{|c|c|}
\hline Iocation & 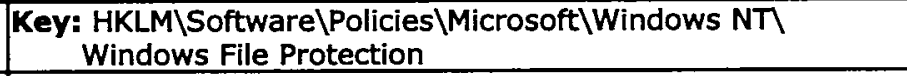 \\
\hline Subfolders always available offline & $\begin{array}{l}\text { Name: AlwaysPinSubFolders } \\
\text { Key: HKLMJSoftware〈Policies\Microsoft/Windows\NetCache }\end{array}$ \\
\hline $\begin{array}{l}\text { Synchronize all offline files before logging } \\
\text { off (Computer) }\end{array}$ & 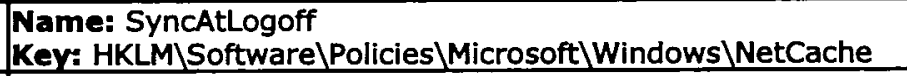 \\
\hline $\begin{array}{l}\text { Synchronize all offline files before logging } \\
\text { off (User) }\end{array}$ & $\begin{array}{l}\text { Name: SyncAtLogoff } \\
\text { Key: HKCU\Software\Policies\Microsoft \Windows } \backslash \text { NetCache }\end{array}$ \\
\hline Timeout for dialog boxes & 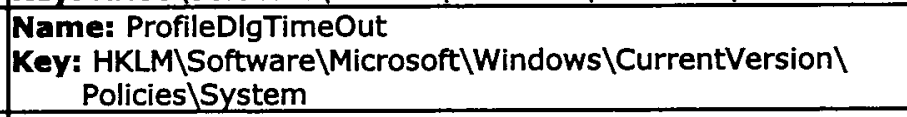 \\
\hline $\begin{array}{l}\text { User Group Policy loopback processing } \\
\text { mode }\end{array}$ & $\begin{array}{l}\text { Name: UserPolicyMode } \\
\text { Key: HKLM\Software\Policies\Microsoft/Windows\System }\end{array}$ \\
\hline Verbose vs normal status messages & $\begin{array}{l}\text { Name: VerboseStatus } \\
\text { Key: HKLM\Software\Microsoft } \backslash \text { Windows } \backslash \text { CurrentVersion } \backslash \\
\text { Policies } \backslash S y s t e m\end{array}$ \\
\hline Wait for remote user profile & $\begin{array}{l}\text { Name: SlowLinkProfileDefault } \\
\text { Key: HKLM\SoftwarelPolicies\Microsoft|Windows\System }\end{array}$ \\
\hline Web-based printing & $\begin{array}{l}\text { Name: DisableWebPrinting } \\
\text { Key: HKLM\Software\Policies\Microsoft\Windows NT\ Printers }\end{array}$ \\
\hline
\end{tabular}

For more information, see the Group Policy Registry Table in the Windows 2000 Professional Resource Kit; "Group Policy Reference" (CD-ROM). 


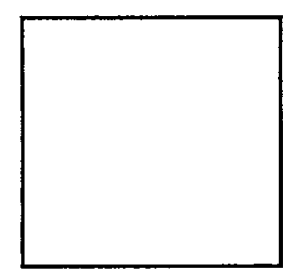

